\title{
10. LATE CRETACEOUS, PALEOGENE AND NEOGENE PLANKTONIC FORAMINIFERA
}

\author{
Valeri A. Krasheninnikov, Moscow, USSR \\ and \\ Robert H. Hoskins, New Zealand Geological Survey, Lower Hutt, New Zealand
}

\section{INTRODUCTION}

Late Cretaceous, Paleogene, and Neogene calcareous deposits containing planktonic foraminifera were recovered in Holes 199, 200, 200A, and 202 near the margin of the Caroline Abyssal Plain. Stratigraphic sections of these holes supplement one another to form a discontinuous composite stratigraphic succession of Cretaceous and Cenozoic deposits. The deposits of the Maastrichtian, late Paleocene, certain zones of the early and middle Eocene, and almost the whole Neogene beginning from the Burdigalian Stage were sampled. Despite stratigraphic incompleteness, these sections are of interest, since the planktonic foraminiferal biostratigraphy of the Late Cretaceous, Paleogene, and Neogene of the tropical area of the Pacific Ocean has been insufficiently studied. Foraminiferal assemblages of Sites 200 and 202 are listed in Tables 1 and 2, and their distribution in the Miocene through Pleistocene at Site 200 is shown in Table 3.

\section{LATE CRETACEOUS}

Late Cretaceous limestones were penetrated in Hole 199. The oldest layers (Core 13) are devoid of planktonic foraminifera. The limestones of Core 12 are characterized by extremely sporadic and small Rugoglobigerina spp., Pseudoguembelina spp., Heterohelix spp., placing these deposits within the Campanian-Maastrichtian stages.

More diverse planktonic foraminifera occur in the limestones of Core 11 (Section 2): Abathomphalus mayaroensis (Bolli), Globotruncanella havanensis (Voorw.), G. petaloidea Gand., Hedbergella monmouthensis (Olsson), Rugoglobigerina hexacamerata Bronn., $R$. ordinaria (Subb.), Heterohelix striata (Ehrenb.), Pseudoguembelina spp., and Guembelitria cretacea Cushm., indicating a late Maastrichtian age (Abathomphalus mayaroensis Zone). Tests of foraminifera are rare and possess thin semitransparent walls with traces of dissolution. This association of planktonic foraminifera is certain to be a result of selective dissolution, indicating that the accumulation of the Maastrichtian calcareous sediments (Core 11) was proceeding at depths near the level of carbonate compensation (the limestones consist predominantly of nannofossils).

The above can be supported by the following: In the foraminiferal limestones of the upper Paleocene of Hole 199 Maastrichtian redeposited foraminifers are very common (Abathomphalus mayaroensis [Bolli], Globotruncana stuartiformis stuartiformis Dalb., G. stuarti [Lapp.], G. contusa [Cushm.], G. gansseri Bolli, Racemiguembelina fructicosa [Egger], Pseudotextularia elegans [Rzehak], Pseudoguembelina excolata [Cushm.], etc.). Tests of these species are characterized by regular size, thick walls, and picturesque ornamentation, and they must be derived from the erosion of Maastrichtian calcareous oozes on the slopes of adjacent guyots during the Paleocene. This indicates that standard assemblages of planktonic foraminifera were living in the area during the Maastrichtian and that the ocean floor in the area of Hole 199 in Maastrichtian time was situated at depths near the level of carbonate compensation.

\section{LAYERS TRANSITIONAL FROM CRETACEOUS TO PALEOGENE}

Late Maastrichtian limestones (the Abathomphalus mayaroensis Zone) are conformably overlain by limestones of similar lithology with extremely peculiar assemblages of planktonic foraminifera (Hole 199; Core 11, Section 1; Core 10, Section 2, $58-145 \mathrm{~cm}$ ). They consist of minute "Globigerina" eugubina Lut. and Premoli Silva, "G." minutula Lut. and Premoli Silva, " $G$." fringa Subb., "G." sabina Lut. and Premoli Silva, "G." anconitana Lut. and Premoli Silva, Chiloguembelina taurica Moroz., and Guembelitria irregularis Moroz. Planktonic foraminiferal tests are sporadic in these rocks; this probably indicates accumulation of calcareous sediments near the level of carbonate compensation.

The above species of "Globigerina" are accompanied by sporadic small and thin-walled Rugoglobigerina ordinaria Subb., Rugoglobigerina sp., Heterohelix sp., Pseudoguembelina spp., Hedbergella monmouthensis (Olsson), Globotruncanella petaloidea Gand., and Abathomphalus mayaroensis (Bolli). It is not certain whether the tests of these foraminifera are in situ or redeposited.

These deposits, with minute "Globigerina," belong to the Globigerina eugubina Zone established by H. Luterbacher and I. Premoli Silva (1964) in continuous sections of Cretaceous-Tertiary deposits of the central Apennines (Italy, Gubbio, Perugia). The limestones of the Globigerina eugubina Zone are of insignificant thickness (not over $0.5 \mathrm{~m}$ ) and in this region separate limestones with typical late Maastrichtian species Abathomphalus, Globotruncana, Rugoglobigerina, Trinitella, Racemigumbelina, Pseudotextularia, Omphalocyclus and Lepidorbitoides from limestones of the Globorotalia pseudobulloidesGlobigerina daubjergensis Zone with a standard microfauna of the Danian Stage (Paleocene).

The planktonic foraminiferal assemblage of the Globigerina eugubina Zone of Italy consists of numerous and minute (usually less than $0.1 \mathrm{~mm}$ ) Globigerina eugubina, $G$. umbrica, $G$. anconitana, G. sabina, G. minutula, and $G$. fringa. $\mathrm{H}$. Luterbacher and I. Premoli Silva believe that the deposits of this zone can be attributed to the lowermost Danian Stage (Paleocene) missing in type-sections of the Danian Stage of Denmark and Sweden. Primitive "Globigerina" of the Globigerina eugubina Zone are 
TABLE 1

Foraminiferal Assemblages, Site 200 Cores

200-2

200-1
nifera: Globorotalia truncatul. inoides, $G$. tumida, $G$. humerosa, G. cultrata, $G$. inflata, G. crassaformis, Sphaeroidinella dehiscens, Pullenia tina obliquiloculata, Globigerinoides conglobatus, G. fistulosus, G. ruber, G. sacculifera, Orbulina universa, Candeina nitida, Hastigerina siphonifera. Pleistocene; Zone N.22.
Abundant and diverse planktonic foraminifera; Sphaeroidinella dehiscens, Pulleniatina obliquiloculata, Globorotalia tumida, $G$. ungulata, $G$. humerosa, $G$. cultrata, $G$. inflata, Globigerinoides fistulosus, G. conglobatus, Candeina nitida together with rare specimens of Globorotalia tosaensis and G. multicamerata.

Late Pliocene; Zone N.21 (basal part, or transition to Zone N.20).

\begin{tabular}{l|l} 
Zone N.20). & $\begin{array}{l}\text { In Sections } 1 \text { and 2 Sphaeroi- } \\
\text { dinellopsis spp., Globigerina nepen- } \\
\text { thes, Globoquadrina altispira are } \\
\text { very rare. Evidently, transition to } \\
\text { Zone N.20. }\end{array}$
\end{tabular}

Assemblages of abundant and very diverse planktonic foraminifera: Sphaeroidinella dehiscens, Sphaeroidinellopsis subdehiscens, Sph. seminulina, Globorotalia tumida tumida, G. humerosa, $G$. crassaformis, G. hirsuta, G. multicamerata, Globigerinoides conglobatus, Globigerina nepenthes, Candeina nitida, Globoquadrina altispira, G. dehiscens, Pulleniatina obliquiloculata. Early Pliocene; Zone N.19.

In Sections 1 and 2 Sphaeroithes, Globoquadrina altispira are Zone N.20.

\begin{tabular}{|c|c|c|c|}
\hline & & 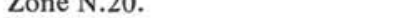 & \\
\hline Abundant planktonic forami- & Planktonic foraminifers of the & The following species of plank- & None. (Mixture of Pliocene, \\
\hline
\end{tabular}
nifera represented by Sphaer. oidinellopsis seminulina, Sph. subdehiscens, Globorotalia tumida plesiotumida, G. miocenica, G. menardii, G. margaritae, G. multicamerata, $G$. acostaensis, Orbulina universa, Globigerina nepenthes, Globigerinoides obliquus extremus, G. bollii, Candeina nitida, Pulleniatina primalis. Upper Miocene; Messinian Stage; Zone N.17.
200-4

Assemblages of abundant planktonic foraminifera include Globorotalia tumida tumida, $G$. miocenica, G. margaritae, Globigerina nepenthes, Sphaeroidinellopsis seminulina, Sph. sub. dehiscens, Orbulina universa, Globoquadrina altispira, Globigerinoides obliquus extremus, Candeina nitida, Pulleniatina primalis, very rare Globorotalia tumida plesiotumida. Upper Miocene; Messinian Stage; Zone N.18. planktonic foraminifera. Uphole contamination.)

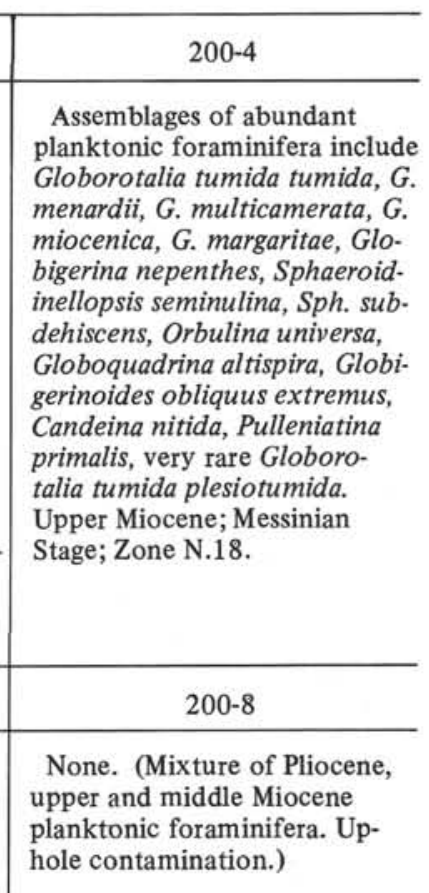

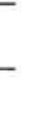

$\sqrt{2}$
menardii, $G$. multicamerata, $G$. upper (Mixture of Pliocene, core catcher and Section 2 are represented by numerous Sphaeroidinellopsis seminulina, Sph. subdehiscens, Globorotalia cultrata, G. menardii, Globigerina nepenthes, Orbulina universa, Globoquadrina dehiscens, G. altispira, common Globigerinoides obliquus extremus, Globorotalia merotumida, rare G. lenguaensis, G. acostaensis, Candeina nitida. Upper Miocene; Tortonian Stage; Zone N.16.

Rare specimens of Globorotalia plesiotumida were found in Section 1. The age of these sediments-Messinian Stage, Zone N.17 (but uphole contamination may take place on account of the soupy character of the oozes). tonic foraminifera are present in the core catcher: abundant Sphaeroidinellopsis subdehiscens, Sph. seminulina, Globigerina nepenthes, Globoquadrina altispira, $G$. dehiscens, common Globorotalia menardii, G. cultrata, G. obesa, Orbulina universa, Globigerina bulloides, Globigerinoides obliquus, G. bollii, rare Globorotalia merotumida, G. acostaensis, G. lenguaensis, Candeina nitida praenitida, Globigerina bulbosa. Upper Miocene; Tortonian Stage, Zone

\begin{tabular}{c|c} 
& \\
\hline $200-9$ & \\
\hline The assemblage of planktonic &
\end{tabular}

The assemblage of planktonic foraminifera of Section 1 consists of Obulinra suturalis, Globoro. talia praemenardii, $G$. obesa, $G$. siakensis;' $G$. peripheroronda, $G$. (Clavatorella) bermudezi, Sphaeroidinellopsis seminulina, Hastigerina siphonifera. Middle Miocene; Zone N.9 (lower part). All other sections (2-6) contain Praeorbulina transitoria, P. glomerosa, Globigerinoides sicanus, G. diminuta, G. mitra, G. trilobus, Globoquadrina dehiscens, $G$. altispira, G. langhiana, G. baroemoenensis, Globigerinatella insueta. Lower Miocene; Burdigalian Stage; Zone N.8.
Core catcher includes sediments
of two different types with foram nifera of different age.

Soft calcareous oozes are characterized by numerous Globigeri. noides sicanus, $G$. trilobus, $G$. subquadratus, Globoquadrina dehiscens, G. altispira together with less abundant Praeorbulina glomerosa, Globigerinoides, diminuta, Globoquadrina langhiana. Lower Miocene; Burdigalian Stage; Zone N.8. Pieces of hard limestone contain numerous Globigerina bradyi, $G$. juvenilis, $G$. binaiensis, $G$. falconensis, Globigerinoides trilobus, common Globoquadrina baroe. moenensis, G. altispira, rare Globigerinita stainforthi, Globoquadrina praedehiscens. Lower Miocene; transition from Aquitanian Stage to Burdigalian Stage; Zone N.6 (upper part).

\begin{abstract}
N.15 (top) or N.16 (base).
\end{abstract}


TABLE 2

Foraminiferal Assemblages, Site 202 Cores

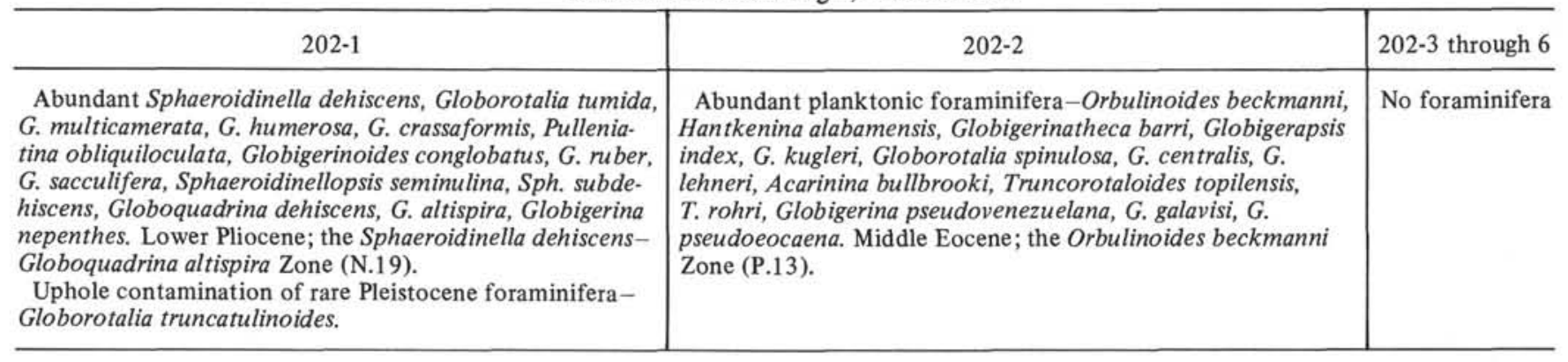

regarded by $\mathrm{H}$. Luterbacher and I. Premoli Silva as a stock from which all Tertiary Globigerinacea have originated (they appear in sediments of the above-lying Globorotalia pseudobulloides-Globigerina daubjergensis Zone).

At present, the deposits of the Globigerina eugubina Zone have been recognized in a limited number of regions of the world; i.e., Italy, the USSR, North Africa, and the Caribbean Sea. In the Soviet Union, the presence of the Globigerina eugubina Zone was established by Nevzorova (1971) eastward of the Caspian Sea in the area of the West Kopet-Dag Ridge (lower part of the Sumbar Horizon). The thickness of deposits of the zone is not great, since that of the whole Sumbar Horizon is not over 27 meters. The Globigerina eugubina Zone is characterized here by small low trochospiral " $G$." eugubina, "G." anconitana, "G." minutula, "G." umbrica, and "G." sabina; no common planktonic and benthonic species of the Maastrichtian Stage have been recognized. Some of the enumerated "Globigerina" species pass into the deposits of the above-lying Globigerina taurica Zone, where G. taurica Moroz., G. eobulloides Moroz., G. tetragona Moroz., G. pentagona Moroz., etc., occur in abundance. The presence of the Globigerina taurica Zone has been established in many regions of the USSR (Crimea, Caucasus, Trans-Caspian area), in Syria and Egypt (Krasheninnikov, 1964, 1965; Krasheninnikov, Abd el Razik, 1969; Fahmy, Krasheninnikov et al., 1969), and on the Shatsky Rise in the Pacific Ocean (Fisher et al., 1971; Krasheninnikov, 1971). We believe that it corresponds to the Globorotalia pseudobulloides-Globigerina daubjergensis Zone in Italy according to the interpretation by H. Luterbacher and I. Premoli Silva (1964).

Blow (in Fisher et al., 1971,p. 1021), while speaking of transitional layers from the Maastrichtian to the Danian Stage, writes: "In parts of the North African area, the extinction of Globotruncana spp. is followed by an interval with small Rugoglobigerina spp. and Pseudoguembelina spp., which the writer considers as equivalent to the 'Globigerina' eugubina zone of Luterbacher and Silva." According to Blow, the age of this interval is sure to be late Maastrichtian, somewhat older than the Globigerina (Eoglobigerina) taurica Zone established by the Soviet micropaleontologists. Blow puts the generic name of Globigerina eugubina in quotation marks as he evidently doubts whether it is correct to assign $G$. eugubina, $G$. sabina, G. minutula, G. umbrica, and $G$. fringa to the genus Globigerina.
Deposits of the Globigerina eugubina Zone were also recognized by $\mathrm{H}$. Bolli and I. Premoli Silva during Deep Sea Drilling Leg 15 in the Caribbean Sea (Edgar et al., 1971). They were penetrated in Holes 152 (the Nicaragua Rise) and 153 (the southern end of the Beata Ridge near Aruba Gap). The assemblage of planktonic foraminifera of the Globigerina eugubina Zone in the Caribbean basin consists of the same species of small Globigerina as those in Italy. Some of these species (Globigerina eugubina, G. sabina) also pass into the deposits of the overlying Globorotalia pseudobulloides Zone (Hole 146, Venezuelan Basin).

In Hole 153, the deposits of the Globigerina eugubina Zone occur unconformably (within one core) on limestones with flints of the early Maastrichtian (the Globotruncana tricarinata Zone). In Hole 152, they are underlain by the middle Maastrichtian (the Globotruncana gansseri Zone). However, the deposits of this age are separated here by an interval (one core) with poor recovery. In the neighboring hole (Hole 146), the Maastrichtian is terminated by sediments of the Abathomphalus mayaroensis Zone.

The recognition of the Globigerina eugubina Zone on the Caroline Abyssal Plain testifies to the wide geographical distribution of this stratigraphic unit (the Pacific Ocean, Caribbean, Mediterranean, Transcaspian area) occupying the same stratigraphic level everywhere; i.e., above the Abathomphalus mayaroensis Zone of the late Maastrichtian and beneath the Globigerina taurica Zone (or synchronous Globorotalia pseudobulloides-Globigerina daubjergensis Zone) of the lower part of the Danian Stage. There are, however, differing opinions concerning the age of the Globigerina eugubina Zone itself; either the top of the Maastrichtian (Blow) or the base of the Paleogene (Luterbacher, Premoli Silva, Bolli, Nevzorova). The solution of this problem is hindered by the poor preservation of material from this zone. Planktonic foraminifera from comparatively hard limestones of the Globigerina eugubina Zone of Italy do not appear to be well preserved, and the character and position of the aperture in Globigerina sabina, G. umbrica, G. minutula, G. eugubina, and $G$. anconitana still remain obscure (in the paper by $\mathrm{H}$. Luterbacher and I. Premoli Silva, 1964, the aperture is shown schematically). Though tests of Globigerina minutula, $G$. sabina, $G$. anconitana, $G$. fringa, and $G$. eugubina in calcareous rocks of the Caroline Abyssal Plain are relatively scarce, they are characterized by excellent preservation. The examination of all specimens showed very convincingly that the aperture does not open into the 
TABLE 3

Distribution of Planktonic Foraminifera, Site 200

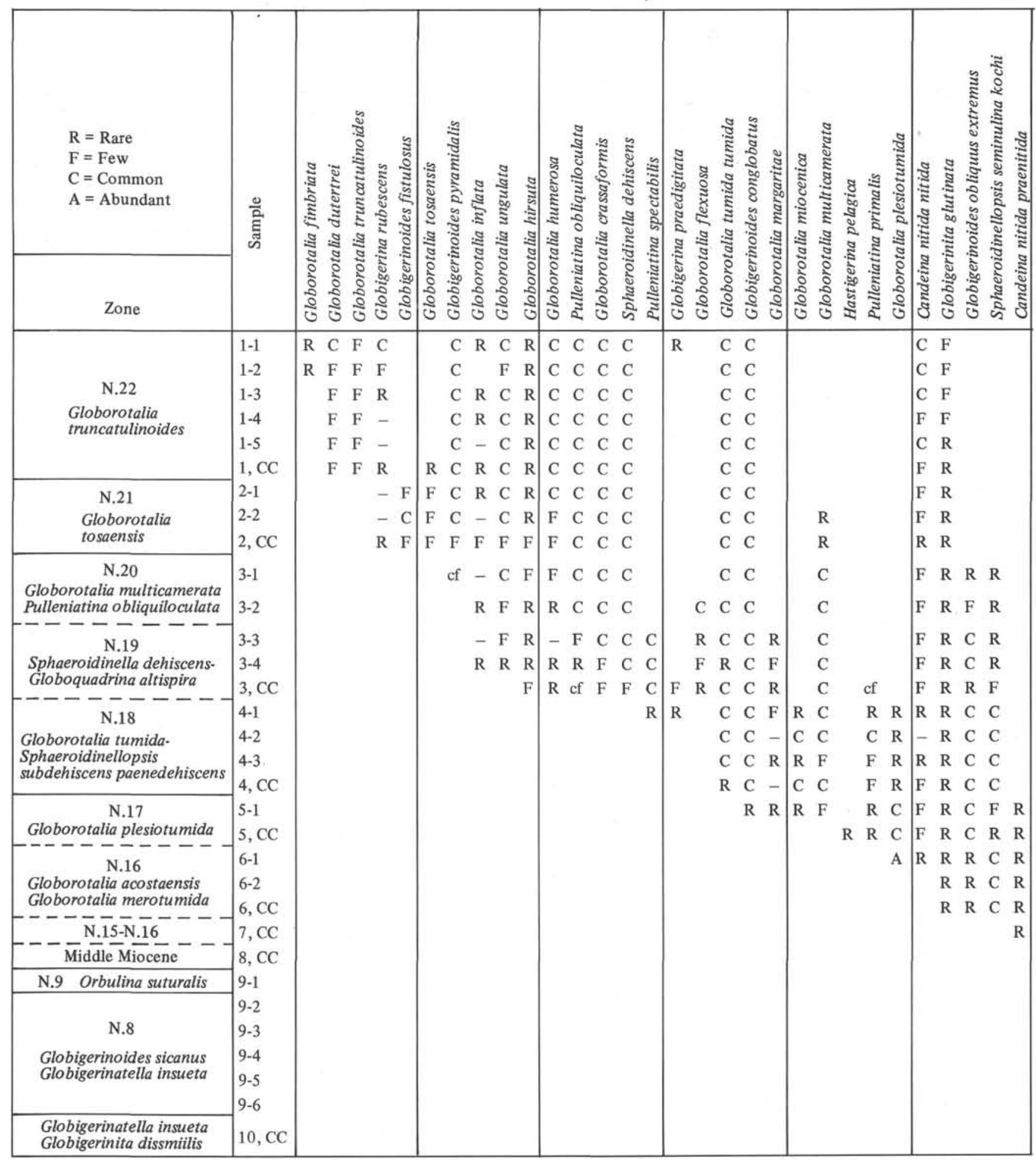


TABLE 3 - Continued

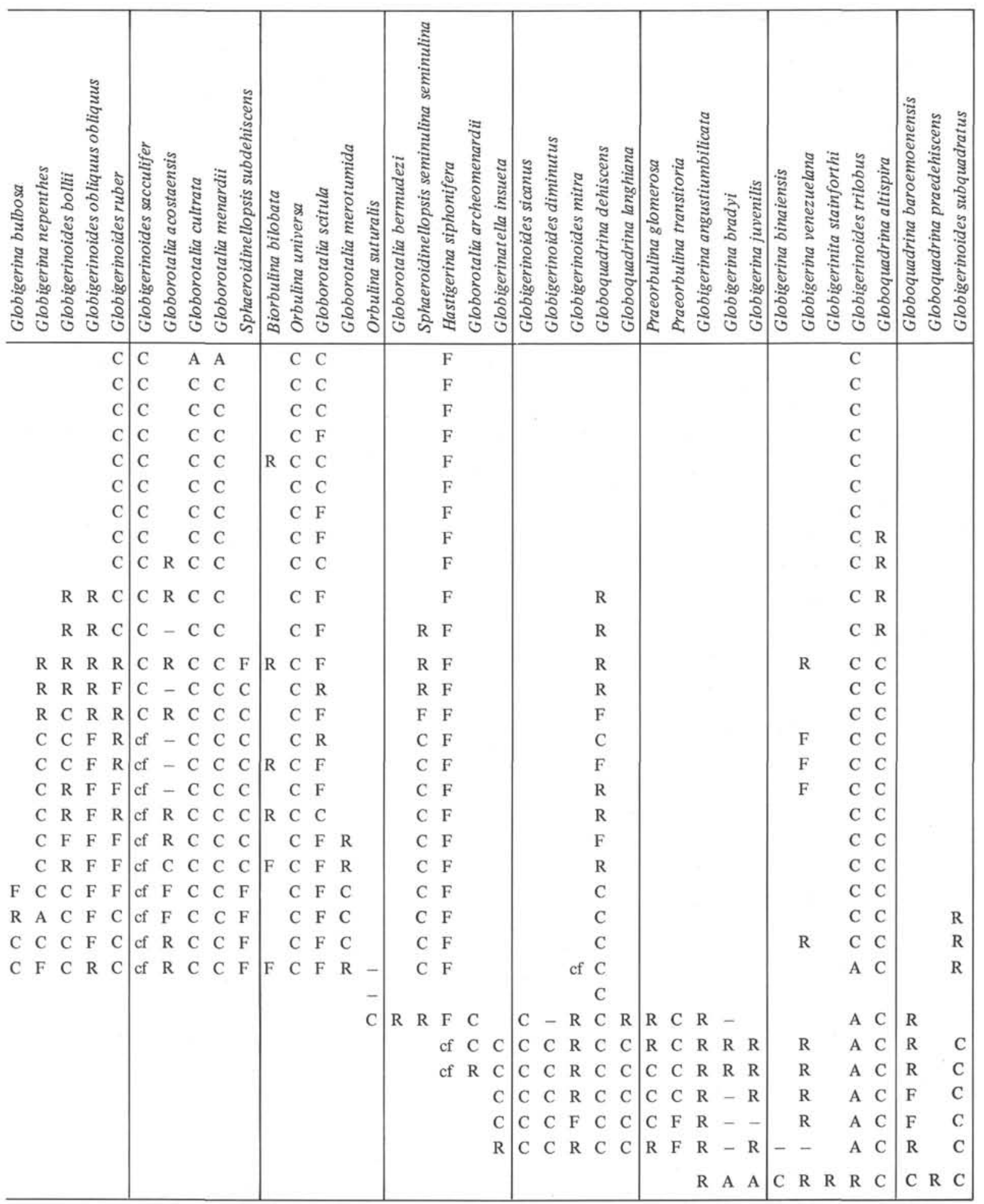


TABLE 4

Numbers of Reworked Foraminifera, Site 200

\begin{tabular}{lc}
\hline Sample & $\begin{array}{c}\text { Reworked Foraminifera } \\
\text { Per 5000 Specimens }\end{array}$ \\
\hline $1-1$ & 2 \\
$1-2$ & - \\
$1-3$ & 2 \\
$1-4$ & - \\
$1-5$ & - \\
$1, \mathrm{CC}$ & - \\
$2-1$ & 2 \\
$2-2$ & 4 \\
$2, \mathrm{CC}$ & 4 \\
$3-1$ & 10 \\
$3-2$ & 11 \\
$3-3$ & 6 \\
$3-4$ & 13 \\
$3, \mathrm{CC}$ & 27 \\
$4-1$ & 23 \\
$4-2$ & 67 \\
$4-3$ & 120 \\
$4, \mathrm{CC}$ & 241 \\
$5-1$ & 260 \\
$5, \mathrm{CC}$ & 192 \\
$6-1$ & 171 \\
$6-2$ & 192 \\
$6, \mathrm{CC}$ & 111 \\
$7, \mathrm{CC}$ & 4 \\
$8, \mathrm{CC}$ & - \\
$9-1$ & - \\
$9-2$ & - \\
$9-3$ & - \\
$9-4$ & - \\
$9-5$ & - \\
$9-6$ & \\
$9, \mathrm{CC}$ & \\
$10, \mathrm{CC}$ & \\
\hline & \\
\hline
\end{tabular}

umbilical area, as it does in typical representatives of the genus Globigerina. The aperture has the shape of a small round opening at the base of the apertural surface (interio-marginal, extra-umbilical). As to the structure of the aperture, the above species of "Globigerina" are closer to the genus Hedbergella, differing in the absence of a narrow lip or spatulate around the umbilical arch.

Thus, it is difficult ot draw any conclusion about the generic affinities of the species of planktonic foraminifera in question; whether they are the last dwarfed representatives of the genus Hedbergella or the first primitive representatives of the genus Globigerina. This is very closely related to the problem of the age of the deposits of the Globigerina eugubina Zone. In the first case, it would be preferable to assign this zone to the top of the Maastrichtian Stage; in the second, to the base of the Danian Stage.

In any case, one may suggest the existence of an extremely brief time interval in geological history (at the Creatceous-Tertiary boundary) when the main mass of Late Cretaceous planktonic foraminifera had already become extinct but when typical Tertiary globigerinids and globorotaliids had not yet appeared. This interval is characterized by rather peculiar assemblages of planktonic foraminifera; small heterohelicids and forms transitional from Hedbergella to Globigerina (?) prevail among them.
It is necessary to prove the existence of the "Globigerina" eugubina Zone in various parts of the world and to study in detail the groups of microfossils characteristic of it so that we may draw a final conclusion about the age of deposits of the Globigerina eugubina Zone and the position of the boundary between the Mesozoic and Cenozoic. In this connection, it is interesting to note that in the Globigerina eugubina Zone of the Caroline Abyssal Plain, Tertiary nannofossils (Coccolithus cavus, Cruciplacolithus tenuis) are already present.

When sediments of the Globigerina eugubina Zone are studied in many regions of the world, it should be possible to determine the true species composition of this zone and whether the rare specimens of Abathomphalus mayarensis, Globotruncanella petaloidea, etc., in the Globigerina eugubina Zone of the Caroline Abyssal Plain are in situ or redeposited. Thus, it may be possible to draw some conclusion as to the age of this zone.

\section{PALEOGENE}

Drilling on the Caroline Abyssal Plain penetrated deposits of the late Paleocene and the early and middle Eocene.

\section{Late Paleocene}

Late Paleocene limestones were recognized in Hole 199 (Cores 7, 8,9,10), where their thickness reaches 86 meters. They rest unconformably on the limestones of the Globigerina eugubina Zone. The stratigraphic gap is marked by a bed of reddish-brown and greenish silicified limestones and grayish-red-brown tuffs (Core 10, Section 2, $50 \mathrm{~cm}$ ). Two zones were distinguished-the Globorotalia pseudomenardii and Globorotalia velascoensis zones. The Danian Stage and the early Paleocene (Globorotalia angulata Zone) are not represented in the section.

The Globorotalia pseudomenardii Zone (Core 10, Section 2, $0.38 \mathrm{~cm}$ ) is characterized by numerous Globorotalia occlusa Loebl. and Tapp., together with less abundant G. laevigata Bolli, G. pseudomenardii Bolli, G. velascoensis parva Rey, G. imitata Subb., and $G$. convexa Subb. The assemblage of planktonic foraminifera is here more diverse, but their tests are poorly preserved, being difficult to extract from the indurated limestones.

The next core, Core 9, already contains a microfauna of the Globorotalia velascoensis Zone, but is is separated from Core 10 by a 57 -meter interval. The planktonic foraminifera of this zone (Cores 9 and 8) include Globorotalia velascoensis (Cushm.), G. occlusa Loebl. and Tapp., G. acuta Toulm., G. laevigata Bolli, G. apanthesma Loebl. and Tapp., G. hispidicidaris Loebl. and Tapp., G. imitata Subb., G. trichotrocha Loebl. and Tapp., G. aequa Cushm. and Renz, Acarinina acarinata Subb., A. mckannai (White), A. primitiva (Finl.), A. strabocella (Loebl. and Tapp.), A. soldadoensis, A. esnaensis (LeRoy), $A$. intermedia Subb. Globigerina nana Khalil., G. compressaformis Khalil., and G. velascoensis Cushm.

Late Paleocene planktonic foraminiferal assemblages of the Caroline Abyssal Plain are rather peculiar. Representatives of genus Globorotalia are markedly predominant in them, those of genus Acarinina are in a subordinate position, and Globigerina species are sporadic. Considering 
only the species of planktonic foraminifera occurring in great numbers (Globorotalia and to a certain extent Acarinina), the upper Paleocene microfauna of the Caroline Abyssal Plain is characterized by low specific diversity.

\section{Early Eocene}

Early Eocene limestones (the Globorotalia formosa formosa Zone) were recovered on Ita Mai Tai Guyot (Hole 200A, Core 2). Planktonic foraminiferal assemblages contain numerous Globorotalia formosa formosa Bolli, $G$. formosa gracilis Bolli, G. marginodentata Subb., G. quetra Bolli, G. wilcoxensis Cushm. and Pont., G. troelseni Loebl. and Tapp., G. apanthesma Loebl. and Tapp., Acarinina triplex Subb., A. pseudotopilensis Subb., A. soldadoensis (Bronn.), A. gravelli (Bronn.), and A. decepta (Mart.) together with less common Globorotalia lensiformis Subb., G. pseudoscitula Glaessn., Acarinina broedermanni (Cushm. and Berm), A. pentacamerata camerata Khalil., Chiloguembelina wilcoxensis (Cushm. and Pont.), Ch. parallela Beckm., and sporadic Globorotalia aragonensis Nutt., $G$. caucasica Glaessn., G. marksi Mart., G. aequa Cushm. and Renz. G. naussi Mart., G. subbotinae Moroz., G. aff. collactea (Finl.), Acarinina esnaensis (LeRoy), A. mckannai (White), A. acarinata Subb., A. pentacamerata pentacamerata (Subb.), Globigerina taroubaensis Bronn., and $G$. prolata Bolli.

Sporadic specimens of Globorotalia aragonensis, $G$. caucasica, G. marksi, and Acarinina pentacamerata pentacamerata indicate that the deposits belong to the uppermost part of the Globorotalia formosa formosa Zone and may prove to be transitional to the deposits of the Globorotalia aragonensis Zone.

Early Eocene planktonic foraminifera of Ita Mai Tai Guyot show two peculiarities:

1) Their assemblages are somewhat more diverse compared with early Paleocene assemblages of the Caroline Abyssal Plain, but, as in the case of the Paleocene assemblages, representatives of genus Globorotalia (in number of species and specimens) are markedly predominant; Acarinina representatives are in a subordinate position and Globigerina species are of sporadic occurrence.

2) Frequently, but not always, specimens of various Acarinina species (A. triplex, A. pseudotopilensis, $A$. soldadoensis, $A$. pentacamerata) are furnished on the spiral side of the test with secondary sutural apertures that occur on the intersection of the intercameral and spiral sutures. Technically, these specimens of Acarinina should be included in the genus Truncorotaloides. There is no doubt, however, that in this case we are dealing with intraspecific variability, and that the appearance of supplementary apertural openings on the spiral side of the shell is of no taxonomic importance at the genus level. The species Acarinina triplex Subb., A. pentacamerata (Subb.), and $A$. pseudotopilensis Subb. were originally described from Eocene deposits of the North Caucasus (USSR), where, however, supplementary apertures on the spiral side were not observed.

Secondary sutural apertures on the spiral side of the shell are considerably less frequent in Globorotalia formosa, $G$. marginodentata, G. quetra, and G. apanthesma from early Eocene deposits of the Caroline Abyssal Plain.
Specimens of the same species from coeval deposits of the North Caucasus have no secondary apertures. Variations in the structure of the spiral side in the above species of Acarinina and Globorotalia are very likely to be regarded as geographical intraspecific variability of planktonic foraminifera.

The appearance of secondary apertural openings in some species of Acarinina and Globorotalia from the Caroline Abyssal Plain is probably indicative of tropical conditions in the Eocene ocean.

Faunal makeup, a numerical dominance of species and specimens of Globorotalia, and a low abundance of Globigerina also indicate tropical conditions during deposition of the late Paleocene and early Eocene sediments of the Caroline Abyssal Plain. It is known that these features characterize the distribution of globorotaliidae and Globigerinidae in the present-day ocean. It is quite possible that the low faunal diversity (taking into account only those species represented by a great number of specimens) was typical for low and high latitudes, and the belt of middle latitudes was characterized by the greatest diversity of planktonic foraminifera. But today, in the area of high latitudes, Globigerinidae strongly prevail, and in the area of low latitudes, Globorotaliidae.

The high rate of accumulation of calcareous biogenic oozes of the late Paleocene, peculiarity of assemblages of planktonic foraminifera of the late Paleocene and early Eocene, and morphological features of planktonic foraminifera of the early Eocene serve as evidence of formation of the biogenic limestones of the late Paleocene and early Eocene under tropical conditions.

\section{Middle Eocene}

Middle Eocene foraminiferal limestones (the Orbulinoides beckmanni Zone) were found at Site 202 in Ita Mai Tai Guyot where they are underlain by oolitic limestones of unknown age. The abundant planktonic foraminifera include Orbulinoides beckmanni Saito, Hantkenina alabamensis Cushm., Globigerinatheka barri Bronn., Globigerapsis index (Finl.), G. kugleri Bolli, Loebl. and Tapp., Globorotalia spinulosa Cushm., G. centralis Cushm. and Berm., G. lehneri Cushm. and Jarv., Acarinina bullbrooki (Bolli), Truncorotaloides topilensis (Cushm), T. rohri Bronn. and Berm., Globigerina pseudovenezuelana Bann. and Blow, G. galavisi Berm., and G.pseudoeocaena Subb.

Despite the relatively poor preservation of the microfauna (the foraminiferal limestones are rather indurated), the spiral side of shells of Truncorotaloides topilensis and $T$. rohri clearly show secondary apertural openings. The latter are absent in specimens of Truncorotaloides topilensis from Eocene deposits of the southern USSR (Armenia, North Caucasus) where this species is usually attributed to the genus Acarinina. Truncorotaloides rohri is not known from the upper part of the Eocene deposits of the south of the USSR. At this stratigraphic level, Acarininas, morphologically similar to Truncorotaloides rohri but devoid of additional apertural openings on the spiral side, can be seen.

The above data indicate the need for a thorough study of the morphology of both Truncorotaloides and Acarinina 
to evaluate their taxonomic independence. The appearance of additional apertural openings on the spiral side of the shell of some globorotaliids apparently represents geographic intraspecific variation.

Present in the Neogene turbidites of Hole 199 are redeposited Globorotalia cerroazulensis (Cole), G. opima opima Bolli, G. pseudokugleri Blow, Globigerina praebulloides Blow, G. angulisuturalis Bolli, G. ouachitaensis Howe and Wall., G. prasaepis Blow, Cassigerinella chipolensis (Cushm. and Pont.), Pseudohastigerina barbadoensis Blow, Chilogümbelina cubensis Palm., and others. These foraminifers testify to the presence of calcareous deposits of the late Eocene and Oligocene on guyots of the Caroline Abyssal Plain, though they were not sampled during Leg 20.

\section{NEOGENE}

Neogene calcareous deposits were recovered on Ita Mai Tai Guyot in Holes 200, 200A, and 202. The oldest Miocene layers (Aquitanian Stage, the Globorotalia kugleri and Globigerinita dissimilis Zones of Bolli's, 1957, zonation) remained unsampled, as Hole 200 did not pass beyond deposits which correspond approximately to the Globigerinita stainforthi Zone.

\section{Early Miocene}

Upper lower Miocene sediments were recovered in Hole 200. The section is incomplete, however, owing to poor recovery.

The lowermost core (Core 10) was empty except for the core catcher sample which includes fragments of deposits of diverse lithology-relatively hard limestones and soft calcareous oozes. These deposits are characterized by planktonic foraminifera of various ages.

The planktonic foraminiferal assemblage from the hard limestones consists of numerous Globigerina bradyi Wiesn., $G$. juvenilis Bolli, G. binaiensis Koch, Globigerinoides trilobus (Reuss), Globoquadrina baroemoenensis Le Roy, together with less frequent Globoquadrina altispira (Cushm. et Jarv.), Globigerinoides subquadratus Bronn., Globigerina falconensis Blow, G. foliata Bolli, G. praebulloides Blow, Globorotalia siakensis (Le Roy) and sporadic Globoquadrina praedehiscens Bann. and Blow, G. dehiscens (Chapm., Parr, and Coll.), Globigerinita unicava (Bolli, Loebl., and Tapp.), G. stainforthi (Bolli, Loebl., and Tapp.), G. incrusta Akers, Cassigerinella chipolensis (Cushm. and Pont.), Globorotalia obesa Bolli, Globigerina venezuelana Hedb., G. angustiumbilicata Bolli, and $G$. bolli, Cita and Premoli Silva.

These limestones most probably belong to the upper part of the Globigerinita stainforthi Zone of Bolli's zonal scheme (or to Zone N.6 of Blow's scheme). The age of these beds is transitional from Aquitanian to Burdigalian.

In the soft calcareous oozes, Globigerinoides sicanus De stefani, $G$. trilobus (Reuss), $G$. diminutus Bolli, $G$. subquadratus Bronn., Globoquadrina dehiscens (Chapm., Parr, and Coll.), and G. altispira (Cushm. and Jarv.) are dominant and are accompanied by less common Globoquadrina langhiana $\mathrm{Cita}$ and Gel., Globorotalia siakensis (Le Roy), G. continuosa Blow, G. peripheroronda Bann. and Blow, G. obesa Bolli, G. minutissima Bolli, Globigerinoides mitra Todd, Globigerina foliata Bolli, G. falconensis Blow, G. praebulloides Blow, Praeorbulina glomerosa (Blow), and $P$. transitoria (Blow).

Soft calcareous oozes with the above species of foraminifera belong to the upper part of the Burdigalian Stage which in the zonal schemes of various authors is either the Globigerinoides sicanus Zone, Praeorbulina glomerosa Zone, or Zone N.8. Poorly developed representatives of the genus Praeorbulina, and primitive $P$. glomerosa show that the deposits belong to the lower part of Zone N.8. The lower part of the Burdigalian Stage (Zone N.7) could not be recognized owing to poor core recovery.

The overlying calcareous oozes of Core 9 (Section 6-2) contain a typical microfauna of Zone N.8-abundant Praeorbulina glomerosa, $P$. transitoria, Globigerinoides sicanus, $G$. diminutus, $G$. mitra, $G$. trilobus, $G$. subquadratus, Globoquadrina dehiscens, $G$. altispira, Globorotalia siakensis, $G$. continuosa, Globigerinatella insueta Cushm. and Stainf., and rare Globorotalia archaeomenardii Bolli.

The first sporadic specimens of Orbulina suturalis Bronn. occur in Section 2 of Core 9, marking the transition to the middle Miocene.

\section{Middle Miocene}

Middle Miocene deposits are represented by their basal beds (the Globorotalia peripheroronda Zone, or Zone N.9). Of considerable importance is the appearance of Orbulina suturalis Bronn., Hastigerina siphonifera (d'Orb.), Sphaeroidinellopsis seminulina (Schw.), Globorotalia praemenardii Cushm. and Stainf., and G. (Clavatorella) bermudezi (Bolli), though they are not abundant. Also present are Globorotalia peripheroronda Bann. and Blow, G. siakensis (Le Roy), G. obesa Bolli, G. continuosa Blow, Globigerinoides trilobus (Reuss), G. subquadratus Bronn., Globoquadrina altispira (Cushm. and Jarv.), G. dehiscens (Chapm., Parr, and Coll.), Globigerina concinna Reuss, and sporadic Praeorbulina glomerosa (Blow) and Globigerinoides sicanus De Stefani.

The above foraminiferal assemblages were seen in Hole 200 (Core 9, Section 1). One could suppose that in Core 8 of this hole the main part of the middle Miocene would be present (Zones N.10-N.13). However, Core 8 proved to be a mixture of sediments with planktonic foraminifera of the Pleistocene, Pliocene, late and middle Miocene. As Globorotalia peripheroacuta Bann. and Blow, G. fohsi Cushm. and Ell., and Biorbulina bilobata (d'Orb.) were found in Core 8, the presence of middle Miocene deposits on the Ita Mai Tai Guyot is confirmed.

\section{Late Miocene}

The late Miocene is regarded here in the scope of the Tortonian and Messinian stages (in accordance with the recommendation given in the Deep Sea Drilling Project Core Description Manual, Part VII: Biostratigraphy), though in many countries the Tortonian Stage crowns the late Miocene.

In Hole 200, the late Miocene is completely represented. However, poor core recovery, the soupy consistency of calcareous oozes, and related uphole contamination make it difficult to draw precise stratigraphic boundaries. 
The Tortonian Stage begins with calcareous ooze (the core catcher of Core 7) with abundant Sphaeroidinellopsis subdehiscens Blow, Sph. seminulina (Schw.), Globigerina nepenthes Todd, Globoquadrina dehiscens (Chapm., Parr, and Coll.) and G. altispira (Cushm. and Jarv.) that are accompanied by less frequent Globorotalia menardii (d'Orb.), G. cultrata (d'Orb.), G. lenguaensis Bolli, G. obesa Bolli, Orbulina universa d'Orb., Globigerina bulloides d'Orb., Globigerinoides obliquus obliquus Bolli, G. bollii Blow, Globigerinita glutinata (Egger), and sporadic Biorbulina bilobata (d'Orb.), Hastigerina siphonifera (d'Orb.), Globigerina bulbosa Le Roy, Globorotalia merotumida Blow and Bann., G. acostaensis Blow, $G$. continuosa Blow, Candeina nitida praenitida Blow, and Globigerinita naparimaensis Bronn. On the basis of these species, the deposits should be assigned to the uppermost part of the Globorotalia continuosa Zone (N.15) or the lower part of the Globorotalia acostaensis-Globorotalia merotumida Zone (N.16). The latter appears to be more probable.

The Globorotalia acostaensis-Globorotalia merotumida Zone (N.16) in its typical form is present in calcareous oozes of Core 6 (the core catcher and Section 2). Here, Globorotalia menardii, G. cultrata, Globigerina nepenthes, Sphaeroidinellopsis seminulina, Sph. subdehiscens, Orbulina universa, and Globigerinoides bollii occur in abundance; they are consistently accompanied by Globorotalia merotumida Blow and Bann., G. paralenguaensis Blow, Globigerinoides obliquus extremus Bolli and Berm., Candeina nitida (d'Orb.), C. nitida praenitida Blow, and sporadic Globorotalia acostaensis Blow, G. margaritae Bolli and Berm., G. pseudopachyderma Cita, Premoli Silva, and Rossi, Globigerinoides adriatica (Forn.), G. parkerae Berm., Globorotaloides variabilis Bolli, Globigerina microstoma Cita, Premoli Silva, and Rossi, G. eamesi Blow, G. decoraperta Tak. and Saito, and G. parabulloides Blow.

Sporadic specimens of Globorotalia tumida plesiotumida Blow and Bann. appear in Section 1 of Core 6. These are likely to be the uppermost beds of the Tortonian Stage (or transition to the Messinian Stage). Precise determination is difficult because of the soupy character of sediments.

Two stratigraphic units can be distinguished in the Messinian Stage: the Globorotalia tumida plesiotumida Zone (N.17) and Globorotalia tumida tumida-Sphaeroidinellopsis subdehiscens paenedehiscens Zone (N.18) after the terminology of Blow. To the Globorotalia tumida plesiotumida Zone (N.17) belong the calcareous oozes of Core 5 (the core catcher and Section 1) with abundant planktonic foraminifera-Globorotalia tumida plesiotumida Blow and Bann., G. miocenica Palm., G. menardii (d'Orb.), G. margaritae Bolli and Berm., G. multicamerata Cushm. and Jarv., G. acostaensis Blow, Sphaeroidinellopsis seminulina Schw.), Sph. subdehiscens Blow, Globigerina nepenthes Todd, G. parabulloides Blow, G. bulloides d'Orb., G. microstoma Cita, Premoli Silva, and Rossi, Globigerinoides obliquus extremus Bolli and Berm., $G$. bollii Blow, G. trilobus (Reuss), Orbulina universa d'Orb., Globoquadrina altispira (Cushm. and Jarv.), Hastigerina siphonifera (d'Orb.), Candeina nitida (D'Orb.), and Pulleniatina primalis Blow and Bann. Specimens of Globorotalia merotumida Blow and Bann. and Biorbulina bilobata (d'Orb.) are sporadic.
Similar assemblages of planktonic foraminifera are indicative of the Globorotalia tumida tumida-Sphaeroidinellopsis subdehiscens paenedehiscens Zone (N.18). They differ mostly in the presence of numerous specimens of Globorotalia tumida tumida (Brady). Somewhat more frequent are Candeina nitida (d'Orb.) and Pulleniatina primalis Blow and Bann., whereas, specimens of Globorotalia tumida plesiotumida Blow and Bann. are sporadic. To this zone are attributed the calcareous oozes of Core 4 (the core catcher, Sections 1,2,3).

Precise determination of the boundary between Zones N.17 and N.18 of the Messinian Stage, and the Miocene and Pliocene (i.e., between Zones N.18 and N.19) is difficult because of the soupy character of calcareous oozes and the resultant uphole contamination. For example, in the calcareous oozes of the upper part of Section 1, Core 5 (Zone N.17), Globorotalia tumida tumida is present and in fact the deposits could be assigned to Zone N.18. In the deposits of Section 1, Core 4 (Zone N.18), rare Sphaeroidinella dehiscens, Globigerinoides conglobatus, $G$. ruber, and G. sacculifer were found; these calcareous oozes could be of Pliocene age (Zone N.19). However, it is most probable that some mixing of weakly consolidated oozes has taken place in the process of drilling.

\section{Pliocene}

Drilling in Ita Mai Tai Guyot encountered deposits of the early (Zone N.19) and upper (Zone N.21) parts of the Pliocene. The middle part of the Pliocene (Zone N.20) was poorly recovered.

The lower part of the Pliocene (the Sphaeroidinella dehiscens-Globoquadrina altispira Zone, or Zone N.19 according to Blow's terminology) was penetrated in Holes 200 (Core 3), 200A (Core 1), and 202 (Core 1). Planktonic foraminifera are abundant and diverse: Sphaeroidinella dehiscens (Park. and Jon.), Sphaeroidinellopsis seminulina (Schw.), Sph. subdehiscens Blow, Globorotalia tumida tumida (Brady), G. humerosa Tak. and Saito, G. crassaformis (Gall. and Wissl.), G. hirsuta (d’Orb.), G. multicamerata Cushm. and Jarv., G. cultrata (d'Orb.), Globigerinoides conglobatus (Brady), G. trilobus (Reuss) Orbulina universa d'Orb., Hastigerina siphonifera (d'Orb.), Candeina nitida (d'Orb.), Pulleniatina obliquiloculata (Park. and Jon.), Globigerina nepenthes Todd, Globoquadrina altispira (Cushm. and Jarv.), G. dehiscens (Chapm., Parr, and Coll.), Globigerina bulloides d'Orb., and G. apertura Cushm.

In Hole 200, calcareous oozes of Sections 1 and 2 (Core 3) contain sporadic Sphaeroidinellopsis spp., Globigerina nepenthes, Globoquadrina altispira, and G. dehiscens, marking a transition to the middle part of the Pliocene (the Globorotalia multicamerata-Pulleniatina obliquiloculata Zone, or Zone N.20).

The upper part of the Pliocene (the Globorotalia tosaensis Zone or Zone N.21) was penetrated in Hole 200 (Core 2). Among the abundant planktonic foraminifera are found a great number of the species common to Zone N.19 (species of Sphaeroidinella, Pulleniatina, Candeina, Globigerinoides, Globorotalia, and Globigerina). However, Globorotalia tosaensis Tak. and Saito appears in this core; Globigerina nepenthes, Globorquadrina altispira, G. dehiscens, species of Sphaeroidinellopsis are absent. The 
presence of sporadic specimens of Globorotalia multicamerata indicates the basal part of Zone N.21.

In Hole 200 upper Pliocene deposits are overlain by Pleistocene calcareous oozes with numerous Globorotalia truncatulinoides (d'Orb.) and belong in the Globorotalia truncatulinoides Zone, or Zone N.22.

\section{REWORKING AND CORE CONTAMINATION IN HOLE 200}

Considerable numbers of reworked foraminifera were found in microfaunal samples from the cores of Hole 200. These reworked foraminifera are often fragmented, abraded, or stained red and are similar in preservation and species composition to foraminifera found in Hole 200A-2, CC and 202-2, CC. The oldest reworked specimens belong to the Globorotalia formosa formosa Zone (early Eocene) and include Acarinina broedermanni, A. decepta, $A$. gravelli, A. mckannai, A. soldadoensis, A. pseudotopilensis, A. triplex, Globorotalia aequa, $G$. apanthesma, $G$. aragonensis, $G$. formosa, G. marginodentata, G. quetra, and $G$. wilcoxensis. All of the recognizable reworking appears to have been confined to Eocene foraminifera. No Oligocene species were found, indicating that Oligocene deposits may not be present on Ita Maitai Guyot.

Table 4 summarizes the numbers of reworked specimens found in five thousand foraminifera split from $10 \mathrm{cc}$ samples.

Cores 2 through 8 contain varying amounts of uphole contamination caused by the liquid nature of the cored sediment. The uniform preservation of foraminifera in the cores, combined with possible intra-core mixing, makes an estimation of the amounts of contamination difficult. Cores 7 and 8 may consist entirely of uphole material.

\section{SYSTEMATICS}

This part of the chapter contains information concerning species and subspecies of planktonic foraminifera that are of interest with regard to morphological, stratigraphic, and geographic distribution and the reconstruction of bionomic conditions. Selected planktonic foraminifera are illustrated by scanning-electron micrographs.

The discussion of each species usually consists of three parts: remarks, containing data on morphology and comparison to specimens of the same species from other regions; stratigraphic occurrence, in sediments penetrated by Leg 20 Holes; and stratigraphic and geographic range, taking into account also data from other areas of occurrence.

This study was aimed mostly at stratigraphic problems. Therefore, the comments on species are given in the order of stratigraphic appearance. As a result, some groups of species are distinguished by stratigraphic subdivisions (transition from Cretaceous to Paleogene, late Paleocene, early Eocene, middle Eocene, Miocene, Pliocene). Some species have long stratigraphic ranges; for these, comments are given in the section dealing with deposits in which these species are most important in determining geological age.

\section{Layers Transitional from Cretaceous to Paleogene}

"Globigerina" minutula Luterbacher and Premoli Silva (Plate 8, Figures 9-11)

1964. Globigerina minutula Luterbacher and Premoli Silva, p. 109, pl. 2 , fig. 5 a-c.

Remarks: Test very small (less than $0.2 \mathrm{~mm}$, sometimes 0.1 $\mathrm{mm}$ ), smooth-walled, with $3 \frac{1}{2}$ chambers in the last whorl. Aperture, a small round opening at the base of the apertural face, extraumbilical, occasionally near the umbilical area.
Stratigraphic occurrence: Hole 199, Cores 10, 11, "Globigerina" eugubina Zone.

Stratigraphic and geographic range: "Globigerina" eugubina Zone (basal layers of the Danian Stage, Paleogene?) of Italy, USSR (Transcaspian area), Pacific Ocean (Caroline Abyssal Plain); Lower part of the Danian Stage (the Globigerina taurica Zone) of the Pacific Ocean (Shatsky Rise).

\section{"Globigerina" fringa Subbotina}

(Plate 8, Figures 1-2)

\section{Globigerina fringa Subbotina, p. 104, pl. 5, Figs. 19-21.}

Remarks: Test very small (diameter $0.12-0.20 \mathrm{~mm}$ ), with a very thin transparent wall, four chambers closely adjacent to one another. Aperture extraumbilical, either a small round opening or a narrow slit at the base of the apertural face. The slit-like aperture of the holotype extends along the base of the apertural face from the umbilicus up to the peripheral margin.

Stratigraphic occurrence: Hole 199, Cores 10, 11, "Globigerina" eugubina Zone.

Stratigraphic and geographic range: The "Globigerina" eugubina Zone (basal layers of the Danian Stage, Paleogene?) of Italy and the Pacific Ocean (Caroline Abyssal Plain); lower part of the Danian Stage (the Globigerina taurica Zone) ${ }^{1}$ of the USSR (Crimea, North Caucasus) and the Pacific Ocean (Shatsky Rise).

\section{"Globigerina" sabina Luterbacher and Premoli Silva (Plate 11, Figures 1-3)}

1964. Globigerina sabina Luterbacher and Premoli Silva, p. 108, pl. 2 , figs. 1a-c, 6a-c, $7 a-c$.

Remarks: Test very small (diameter-0.1-0.2 mm), with a transparent, smooth wall, the last whorl having $4 \frac{1}{2}$ to 5 chambers. Aperture extraumbilical in the shape of an arc-like opening or a low slit at the base of the apertural face.

Stratigraphic occurrence: Hole 199, Cores 10, 11, "Globigerina" eugubina Zone.

Stratigraphic and geographic range: The "Globigerina" eugubina Zone (basal beds of the Danian Stage, Paleogene?) of Italy, USSR (Transcaspian area), the Pacific Ocean (Caroline Abyssal Plain); lower part of the Danian Stage (the Globigerina taurica Zone) of the Pacific Ocean (Shatsky Rise).

\section{"Globigerina" eugubina Luterbacher and Premoli Silva (Plate 7, Figures 6-8)}

1964. Globigerina eugubina Luterbacher and Premoli Silva, p. 105, pl. 2 , fig. 8a-c.

Remarks: Test very small (diameter-0.12-0.20 mm), trochospiral, but strongly compressed on the spiral and umbilical sides, with $5^{1 / 2}$ to 6 chambers in the last whorl. Wall smooth, transparent. Aperture extraumbilical, in the shape of a small rounded opening or an arc-like slit at the base of the apertural face.

Stratigraphic occurrence: Hole 199, Cores 10,11, "Globigerina" eugubina Zone.

Stratigraphic and geographic range: "Globigerina" eugubina Zone (basal beds of the Danian Stage, Paleogene?) of Italy, USSR (Transcaspian area), Atlantic Ocean (Nicaragua Rise, Hole 152, Beata Ridge, Hole 153), the Pacific Ocean (Caroline Abyssal Plain).

"Globigerina" umbrica Luterbacher and Premoli Silva (Plate 11, Figures 7-9)

1964. Globigerina umbrica Luterbacher and Premoli Silva, p. 106, pl. 2 , fig. $2 \mathrm{a}-\mathrm{c}$.

Remarks: Test very small (diameter-0.10-0.18), compressed on the spiral and umbilical sides, with six to seven spherical chambers in the last whorl that increase slightly in size as added. Wall smooth, transparent. Aperture, an arc-like slit at the base of the apertural face, extraumbilical.

\footnotetext{
${ }^{1}$ In some cases the Globigerina (Eoglobigerina) taurica Zone very likely includes deposits of the "Globigerina" eugubina Zone as well.
} 
Stratigraphic occurrence: Hole 199, Cores 10,11, "Globigerina" eugubina Zone.

Stratigraphic and geographic range: The "Globigerina" eugubina Zone (basal beds of the Danian Stage, Paleogene?) of Italy, USSR (Transcaspian area), the Pacific Ocean (Caroline Abyssal Plain).

\section{Guembelitria irregularis Morozova}

$$
\text { (Plate 31, Figures 1-2) }
$$

1961. Guembelitria irregularis Morozova, p. 17, pl. 1, figs. 9, 10.

Remarks: Test tiny, high; height $(0.20-0.25 \mathrm{~mm})$ is two to two and a half times more than the width near the apertural end $(0.9-0.12 \mathrm{~mm})$. Spire consists of six or seven whorls with $2 \frac{1}{2}$ to 3 chambers each. The number of chambers in adjacent whorls varies; for this reason, the chambers do not form regular vertical rows.

Stratigraphic occurrence: Hole 199, Cores 10,11, "Globigerina" eugubina Zone.

Stratigraphic and geographic range: "Globigerina" eugubina Zone of the Pacific Ocean (Caroline Abyssal Plain); Globigerina taurica Zone (the lower part of the Danian Stage) of the USSR (Crimea, Caucasus, Russian platform) and the Pacific Ocean (Shatsky Rise).

\section{Chiloguembilina taurica Morozova}

(Plate 5, Figure 1)

1961. Chiloguembelina taurica Morozova, p. 18, pl. 1, figs. 7, 8 .

Remarks: Test tiny, high $(0.4-0.5 \mathrm{~mm})$, and narrow $(0.23-0.29$ $\mathrm{mm}$ ), laterally compressed; has the shape of a sharp wedge. Test consists of two rows of chambers, five to six chambers in each row. The initial chambers are relatively low, subspherical; the last chambers are larger, spherical.

Stratigraphic occurrence: Hole 199, Cores 10,11, "Globigerina" eugubina Zone.

Stratigraphic and geographic range: "Globigerina" eugubina Zone of the Pacific Ocean (Caroline Abyssal Plain); Globigerina taurica Zone (the lower part of the Danian Stage) of the USSR (Crimea, Caucasus, Russian platform) and the Pacific Ocean (Shatsky Rise).

\section{PALEOGENE}

Upper Paleocene

\section{Globorotalia velascoensis (Cushman)}

(Plate 30, Figures 4-6)

1925. Pulvinulina velascoensis Cushman, p. 19 , pl. 3 , fig. 5 a-c.

Stratigraphic occurrence: Hole 199. In the assemblage of planktonic foraminifera from deposits of the lowermost upper Paleocene (the Globorotalia pseudomenardii Zone) this species occupies a subordinate position (Core 10). In the deposits of the uppermost Paleocene (the Globorotalia velascoensis Zone) it is abundant (Cores 8,9).

Stratigraphic and geographic range: This species is very well known from upper Paleocene deposits of many regions of Europe, Asia, Africa, America, and Australia. Very sporadic specimens occur in the basal beds of the lower Eocene (the lower part of the Globorotalia subbotinae Zone).

Upper Paleocene deposits with Globorotalia velascoensis were recovered by drilling in the Caribbean Sea, the southern part of the Atlantic Ocean, and Pacific Ocean (Shatsky Rise, Caroline Abyssal Plain).

This species is very sporadic in the upper Paleocene of the USSR (Crimea, North Caucasus).

\section{Globorotalia acuta Toulmin}

(Plate 17, Figures 7-9)

1941. Globorotalia wilcoxensis var. acuta Toulmin, p. 608, pl. 82, figs. 6-8.

Remarks: G. acuta differs from a similar species, $G$. velascoensis, by possessing fewer chambers (4-6) in the last whorl, a rapid increase in size of chambers within the last whorl, a large last chamber (occupies $1 / 4-1 / 3$ part of the whorl), a less well-developed ornamentation of the umbilical shoulders of chambers and the peripheral keel.
Stratigraphic occurrence: Hole 199, Cores 8, 9; common species of the Globorotalia velascoensis Zone.

Stratigraphic and geographic range: The upper part of upper Paleocene deposits of many countries of the Caribbean, Mediterranean, Africa, Europe, Asia, Australia, and New Zealand.

It was found during drilling performed by Glomar Challenger in the northern and southern parts of the Atlantic Ocean and Pacific Ocean (Shatsky Rise, Caroline Abyssal Plain).

\section{Globorotalia occlusa Loeblich and Tappan}

(Plate 26, Figures 4-6)

1957. Globorotalia occlusa Loeblich and Tappan, p. 191, pl. 64, fig. $3 \mathrm{a}-\mathrm{c}$.

Remarks: This species differs from Globorotalia velascoensis by a smaller test size, a lens-like shape of the test with a strongly convex side, slight ornamentation of the spiral and septal sutures, and a smaller umbilicus.

Stratigraphic occurrence: Hole 199; abundant in Core 10 (Globorotalia pseudomenardii Zone); in Cores 8 and 9 (Globorotalia velascoensis $Z$ one) specimens of this species are less abundant.

Stratigraphic and geographic range: The upper Paleocene of the United States, Mexico, Australia, New Zealand, some countries of the Caribbean, Mediterranean, Europe, Asia, Africa. It was found during drilling in the upper Paleocene sediments of the Atlantic and Pacific oceans.

\section{Globorotalia pseudomenardii Bolli (Plate 27, Figures 1-3)}

1957. Globorotalia pseudomenardii Bolli, p. 77, pl. 20, figs. 14-17.

Stratigraphic occurrence: Hole 199. Typical specimens of this species are rather common in deposits of the Globorotalia pseudomenardii Zone (Core 10); in limestones of the Globorotalia velascoensis Zone (Cores 8 and 9) they were not found.

Stratigraphic and geographic range: This species is diagnostic for deposits of the lower part of the upper Paleocene (the Globorotalia pseudomenardii Zone) in the United Stages, USSR, Australia, New Zealand, many countries of the Mediterranean, Europe, Asia, Africa, and the Caribbean. In deposits of this age, $G$. pseudomenardii was found during drilling in some regions of the Atlantic and Pacific oceans. In the upper part of the upper Paleocene (the Globorotalia velascoensis Zone), $G$. pseudomenardii is known in a limited number of specimens (Syria, Rio Grande Rise in the Atlantic Ocean, Shatsky Rise in the Pacific Ocean.

\section{Globorotalia laevigata Bolli \\ (Plate 23, Figures 4-6)}

1956. Globorotalia pusilla laevigata Bolli, p. 78, pl. 20, figs. 5-7.

Remarks: Globorotalia laevigata is regarded as an independent species differing from $G$, pusilla Bolli in a rounded test outline (equatorial section) and a sharply keeled peripheral margin.

Stratigraphic occurrence: Hole 199. Relatively few specimens in deposits of the Globorotalia pseudomenardii and Globorotalia velascoensis Zones (Cores $8,9,10$ ).

Stratigraphic and geographic range: This species is known from the upper Paleocene of Trinidad, United States, Nigeria, Syria, Egypt, New Zealand, and other countries.

During drilling, the species was found in the upper Paleocene or the Atlantic Ocean (Rio Grande Rise) and the Pacific Ocean (Shatsky Rise, Caroline Abyssal Plain).

\section{Globorotalia hispidicidaris Loeblich and Tappan (Plate 22, Figures 4-6)}

1957. Globorotalia hispidicidaris Loeblich and Tappan, p. 190, pl. 58 , fig. 1a-c.

Remarks: The specimens of $G$. hispidicidaris from upper Paleocene sediments of the Caroline Abyssal Plain are surprisingly similar to the holotype of this species described by Loeblich and Tappan from the Aquia Formation (USA). However, on the spiral side of the test of some of them, there were small additional apertural openings (at the intersection of the septal sutures with the spiral sutures.

Stratigraphic occurrence: Hole 199, Cores 8, 9, the Globorotalia velascoensis Zone. 
Stratigraphic and geographic range: This species has been recorded from deposits of the upper part of the upper Paleocene in the United States, Egypt, Syria, the USSR (North Caucasus) and through drilling in the Pacific Ocean (Shatsky Rise, Caroline Abyssal Plain). Sporadic specimens of $G$. hispidicidaris are present at the base of the lower Eocene (the lower part of the Globorotalia subbotinae Zone) of the USSR and Caroline Abyssal Plain.

\section{Globorotalia imitata Subbotina}

$$
\text { (Plate 22, Figures 10-12) }
$$

1953. Globorotalia imitata Subbotina, p. 206, pl. 16, figs. 14a-c, $15 \mathrm{a}-\mathrm{c}, 16 \mathrm{a}-\mathrm{c}$.

Remarks: Specimens of G. imitata from upper Paleocene sediments of the Caroline Abyssal Plain are very similar morphologically to the topotypes of this species, described from Paleocene deposits of the USSR (North Caucasus).

Stratigraphic occurrence: Hole 199, Core 10 (the Globorotalia pseudomenardii Zone), Cores 8, 9 (the Globorotalia velascoensis Zone).

Stratigraphic and geographic range: The upper Paleocene of many regions of the world; i.e., the USSR, Syria, Egypt, Australia, the United States, the Atlantic Ocean (Rio Grande Rise), and the Pacific Ocean (Shatsky Rise, Caroline Abyssal Plain).

\section{Acarinina intermedia Subbotina}

(Plate 2, Figures 3-5)

1953. Acarinina intermedia Subbotina, p. 227, pl. 20, figs. 1 a,b,c-4a,b,c; $14 \mathrm{a}, \mathrm{b}, \mathrm{c}-16 \mathrm{a}, \mathrm{b}, \mathrm{c}$.

Remarks: Acarinina intermedia, described by Subbotina from deposits of the upper Paleocene-lower part of the lower Eocene of the USSR (North Caucasus), is very similar to Acarinina esnaensis (LeRoy) in morphology. The latter was described by LeRoy also in 1953 from the Esna shales (upper Paleocene-lower part of the lower Eocene) of the Farafra Oasis, Egypt. Acarinina intermedia is characterized by a test half the size of that of A. esnaensis, a more rounded outline of the test, and tighter arrangement of chambers of the last whorl. However, separation of these two species of Acarinina has to be confirmed by further studies.

Stratigraphic occurrence: Hole 199, Cores 8 and 9, the Globorotalia velascoensis Zone.

\section{Acarinina primitiva (Finlay) \\ (Plate 3, Figures 4-6)}

1947. Globoquadrina primitiva Finlay, p. 291, pl. 8, figs. 129-134. Remarks: The holotype of "Globoquadrina" primitiva was described by Finlay from middle Eocene deposits of New Zealand (Bortonian Stage). This species has been attributed by Jenkins to the new genus Pseudogloboquadrina, $P$. primitiva being given a long stratigraphic range; i.e., Paleocene-middle Eocene. In literature describing the Paleogene deposits of the USSR, Austria, Syria, Egypt, Tunisia, Senegal, Nigeria, Trinidad, and Cuba, this species is usually mentioned from deposits of the upper Paleocene and the lowermost Eocene. In this relation, the scope of the species Acarinina (Pseudogloboquadrina?) primitiva is worth thorough study.

Stratigraphic occurrence: Hole 199, Cores 8 and 9, Globorotalia velascoensis Zone.

\section{Acarinina acarinata Subbotina}

(Plate 1, Figures 1-3)

1953. Acarinina acarinata Subbotina, p. 229 , pl. 22, figs. $4 \mathrm{a}, \mathrm{b}, \mathrm{c}-10 \mathrm{a}, \mathrm{b}, \mathrm{c}$.

Remarks: Tests are medium sized $(0.3-0.5 \mathrm{~mm}$ in diameter), round or oval in the equatorial section, with 4 to $4 \frac{1}{2}$ chambers tightly arranged in the last whorl. The chambers are elongated in the direction of test growth. The umbilical side is strongly convex, subspherical; the spiral side is slightly convex. Umibilicus is small. The peripheral margin is widely rounded.

It is possible that this species is a junior synonym of Acarinina nitida (Martin) from the Lodo Formation of California.

Stratigraphic occurrence: Hole 199, Cores 8 and 9 (upper Paleocene, the Globorotalia velascoensis Zone), where this species is rather common. Hole 200A, Core 2 (lower Eocene, the Globorotalia formosa formosa Zone) where Acarinina acarinata is represented by very rare specimens.

Stratigraphic and geographic range: Acarinina acarinata is abundant in deposits of the uppermost Paleocene (the Acarinina acarinata Zone) of the USSR (North Caucasus, Crimea, Transcaspian area, Georgia), and can still be found in a subordinate number of specimens in the lowermost Eocene (the Globorotalia subbotinae Zone and the Globorotalia marginodentata Zone) of the USSR.

In deposits of the same age, $A$. acarinata has been recorded from localities in Bulgaria, Austria, Syria, Egypt, and in the Pacific Ocean (Shatsky Rise, Caroline Abyssal Plain). This is indicative of wide geographical distribution for this species. The problem is whether its specific name is correct (acarinata or nitida). This requires a comparative analysis of specimens from the Caucasus and California.

\section{Acarinina mckannai (White)}

(Plate 2, Figures 6-8)

1928. Globigerina mckannai White, p. 194, pl. 27, fig. 16.

Remarks: This species was described by White from deposits of the Velasco Formation of Mexico. Considerably better illustrations of A. mckannai were given by Loeblich and Tappan (1957) and Bolli (1957). The Loeblich and Tappan specimens were obtained from the Vincentown Formation (New Jersey), the Aquia Formation (Maryland, Virginia), the Salt Mountain Limestone (Alabama) of the United States and the Velasco Formation of Mexico; and the Bolli specimens, from the Lizard Springs Formation of Trinidad. Hypotypes and lectotypes of Acarinina mckannai indicate that Acarinina subsphaerica (Subbotina), 1947, from Paleocene and lower Eocene deposits of the USSR is a junior synonym.

Stratigraphic occurrence: Hole 199, Cores 8 and 9, Globorotalia velascoensis Zone. Very rare specimens of this species were detected in lower Eocene deposits (the Globorotalia formosa formosa Zone) of Hole $200 \mathrm{~A}$, Core 2.

Stratigraphic and geographic range: The species has been observed in deposits of the upper Paleocene and the lower part of the lower Eocene of many countries of Europe, Mediterranean, Africa, Asia, America, as well as in Australia and New Zealand. It was also seen during drilling in the Atlantic and Pacific oceans.

\section{Globigerina velascoensis Cushman}

(Plate 11, Figures 10-12)

\section{Globigerina velascoensis Cushman, p. 19, pl. 3, fig. 6 .}

Remarks: This species is indicative of upper Paleocene deposits. It is characterized by a medium sized test $(0.3-0.4 \mathrm{~mm})$ with a strongly lobate equatorial outline; the last whorl contains four chambers that rapidly increase in size; the last chamber usually occupies $1 / 3$ of the whorl; the chambers are inflated, laterally compressed; the umbilical side is strongly inflated, the spiral side is slightly convex. The aperture has a distinct lip.

Stratigraphic occurrence: Hole 199, Cores 8 and 9, Globorotalia velascoensis Zone.

Stratigraphic and geographic range: The species is known from upper Paleocene deposits of the United States (California, the Gulf coast), Mexico, Trinidad, Cuba, Senegal, Nigeria, many Mediterranean countries; it was recovered in deposits of this age during drilling in the Atlantic Ocean (Rio Grande Rise, Bay of Biscay) and in the Pacific Ocean (Shatsky Rise, Caroline Abyssal Plain).

\section{Globigerina nana Khalilov (Plate 9, Figures 1-3)}

1956. Globigerina triloculinoides var. nana Khalilov, p. 236, pl. 1, fig. $4 \mathrm{a}, \mathrm{b}, \mathrm{c}$.

Remarks: Test small (diameter $0.24-0.29 \mathrm{~mm}$ ), strongly inflated, almost square. Initial whorls can hardly be seen. The last whorl contains three chambers, the last of which is arranged perpendicular to the previous two. Septal sutures are straight. The surface of the wall is roughly reticulate. The aperture is slit-like with a small lip.

Stratigraphic occurrence: Hole 199, Cores 8 and 9, Globorotalia velascoensis Zone. This species is represented here by rare specimens. 
Stratigraphic and geographic range: Globigerina nana is of ten observed in upper Paleocene deposits of the USSR (North Caucasus, Transcaucasian and Transcaspian areas); this species is known in subordinate numbers of specimens from the lower part of the lower Eocene of these regions. It has also been recorded from the upper Paleocene of the Mediterranean (Syria, Egypt), United States (California) and the Pacific Ocean (Shatsky Rise, Caroline Abyssal Plain).

Early Eocene

\section{Globorotalia aequa Cushman and Renz}

(Plate 17, Figures 10-12)

1942. Globorotalia crassata var. aequa Cushman and Renz, p. 18, pl. 3 , fig. 3a-c.

Remarks: Relatively sporadic specimens of this species possess all characteristics of Globorotalia aequa.

Stratigraphic occurrence: Hole 199. Core 8, upper Paleocene, Globorotalia velascoensis Zone; Hole 200A, Core 2, Globorotalia formosa formosa Zone.

Stratigraphic and geographic range: This species is known to be widely distributed in Paleogene deposits of many areas. It is a consistent element of the assemblage of planktonic foraminifera in the uppermost Paleocene (the uppermost part of the Globorotalia velascoensis Zone), and lowermost Eocene (the Globorotalia subbotinae Zone). Higher, in deposits of the Globorotalia formosa formosa Zone, only sporadic specimens of $G$. aequa occur. It was seen during drilling in the Pacific and Atlantic oceans.

\section{Globorotalia subbotinae Morozova} (Plate 28, Figures 10-12)

1939. Globorotalia subbotinae Morozova, p. 80, pl. 2, figs. 16, 17.

Remarks: This species was originally described by Morozova from the lowermost Eocene of the USSR (Transcaspian area, the Emba Basin). It differs from Globorotalia aequa by a lens-like test (in $G$. aequa the spiral side is almost flat, the umbilical side is convex), more loose coiling (in the last whorl there are, as a rule, four chambers in a cruciform arrangement), and a distinct ornamented keel. 1943 .

A junior synonym of this species is Globorotalia rex Martin,

Stratigraphic occurrence: Hole 200A, Core 2, Globorotalia formosa formosa Zone (very rare specimens).

Stratigraphic and geographic range: Sporadic specimens of Globorotalia subbotinae seem to appear at the top of the upper Paleocene. In the lowermost Eocene (the Globorotalia subbotinae Zone), this species is abundant. Higher, in the Globorotalia formosa formosa Zone, the number of specimens in planktonic foraminiferal assemblages rapidly increases.

This species (as Globorotalia subbotinae or G. rex) has been described from the lowermost Eocene of many areas. The species was also encountered during drilling performed by Glomar Challenger in the Atlantic Ocean (Rio Grande Rise, Bahama Banks, Bay of Biscay, Venezuela Basin, Beata Ridge) and the Pacific Ocean (Shatsky Rise, Caroline Abyssal Plain).

\section{Globorotalia marginodentata Subbotina}

(Plate 24, Figures 5-7)

1953. Globorotalia marginodentata Subbotina, p. 212, pl. 18, figs. $1 \mathrm{a}, \mathrm{b}, \mathrm{c},-3 \mathrm{a}, \mathrm{b}, \mathrm{c}$,

Remarks: Globorotalia marginodentata differs from the similar species G. subbotinae by a flattened lenticular test, a lobate peripheral margin, a wide and thick keel, and a larger number of chambers in the last whorl (usually 5 , sometimes $4 \frac{1}{2}$ or 6 ).

Stratigraphic occurrence: Hole 200A, Core 2, Globorotalia formosa formosa Zone.

Stratigraphic and geographic range: In the USSR (the Carpathians, Crimea, Transcaspian area), this species (sporadic specimens) appears starting at the base of the lower Eocene (the Globorotalia subbotinae Zone). Higher, in the deposits of the Globorotalia marginodentata Zone, this species becomes widely distributed, its last specimens disappearing in the basal layers of the Globorotalia aragonensis Zone.
Globorotalia marginodentata from the deposits of the lowermost Eocene has been found in Syria, Rumania, Egypt, Austria, Yugoslavia, Italy. Tunisia and New Zealand. Drilling has established the presence of this species in the lower Eocene of the Atlantic Ocean (Rio Grande Rise, Bahama Banks, Bay of Biscay) and that of the Pacific Ocean (Shatsky Rise, Caroline Abyssal Plain).

\section{Globorotalia formosa gracilis Boll}

(Plate 21, Figures 7-9)

1957. Globorotalia formosa gracilis Bolli, p. 75, pl, 18, fig. 4-6.

Remarks: Globorotalia formosa gracilis differs from G. marginodentata by an irregular lens-like test (the umbilical side of the test is much more convex as compared to the spiral side), a less lobate peripheral margin, a gradual increase in chamber size, and a less well developed keel.

Stratigraphic occurrence: Hole 200A, Core 2, Globorotalia formosa formosa Zone.

Stratigraphic and geographic range: The species is widelydistributed in deposits of the lowermost Eocene (the Globorotalia subbotinae Zone and the Globorotalis formosa formosa Zone). It was found during drilling in the Atlantic Ocean (Rio Grande Rise, Bahama Banks, Bay of Biscay) and the Pacific Ocean (Shatsky Rise, Caroline Abyssal Plain, Hole 39 off the west coast of California).

\section{Globorotalia formosa formosa Bolli}

(Plate 21, Figures 4-6)

1957. Globorotalia formosa formosa Bolli, p. 76, pl. 18, figs. 1-3.

Remarks: This species differs from $G$. formosa gracilis by a larger test, a greater number of chambers in the last whorl (6-8 instead of 5-6), and a more conical umbilical side.

Stratigraphic occurrence: Hole 200A, Core 2, the Globorotalia formosa formosa Zone.

Stratigraphic and geographic range: This is a typical species of the lower Eocene, abundant in deposits of the Globorotalia formosa formosa Zone (this zone corresponds to the Globorotalia marginodentata Zone in the Paleogene of the USSR), and can be found in subordinate numbers of specimens in the Globorotalia aragonensis Zone. In the deposits of this age, the species was established in the USSR, Syria, Egypt, Tunisia, Italy, Senegal, Nigeria, Trinidad, Cuba, the United States, India and other countries. During drilling, $G$. formosa formosa was found in the lower Eocene of the Atlantic Ocean (Rio Grande Rise, Bay of Biscay) and the Pacific Ocean (Shatsky Rise, Caroline Abyssal Plain).

Globorotalia lensiformis Subbotina

(Plate 23, Figures 10-12)

1953. Globorotalia lensiformis Subbotina, p. 214, pl, 18, figs. 4a, b, c-5a, b, c.

Remarks: Tests large $(0.45-0.60 \mathrm{~mm})$, conical; spiral side slightly convex, umbilical side strongly convex. The last whorl consists of four or five chambers that rapidly increase in size. The last chamber is large, and occupies up to $1 / 3$ of the final whorl. The peripheral margin is sharp, lobate, and ornamented with a thin keel. Umbilical ends of the chambers are closely connected with one another, the umbilicus being very small.

Stratigraphic occurrence: Hole 200A, Core 2, Globorotalia formosa formosa Zone.

Stratigraphic and geographic range: This species was originally described from lower Eocene deposits of the USSR, where it can be found in the upper part of the Globorotalia marginodentata Zone and in the lower part of the Globorotalia aragonensis Zone.

Globorotalia lensiformis is widely-distributed, though it is known from a limited number of places: Mediterranean (Syria, the top of the Globorotalia marginodentata Zone), the Atlantic Ocean (Rio Grande Rise, Hole 21, undifferentiated Globorotalia aragonensis-Globorotalia formosa formosa Zones; Labrador Sea, Hole 111, undifferentiated Globorotalia subbotinae-Globorotalia formosa formosa Zones), and the Pacific Ocean (Shatsky Rise, Caroline Abyssal Plain). 
Globorotalia aragonensis Nuttall

(Plate 18, Figures 4-6)

1930. Globorotalia aragonensis Nuttall, p. 288 , pl.24, figs. $6-8$, 10-11.

Remarks: Globorotalia lensiformis Subb. seems to be included by many micropaleontologists within the range of variation $G$. aragonensis Nutt. The latter is characterized by a larger highly-conical test with an almost flat spiral side, a greater number of chambers (6-8) in the last whorl, a slow increase in test size, a slightly lobulate (almost even) peripheral margin, a thicker test wall, a well-developed keel, and a deep umbilicus.

Stratigraphic occurrence: Hole 200A, Core 2, top of the Globorotalia formosa formosa Zone (rare specimens).

Statigraphic and geographic range: It is distributed in lower Eocene deposits of many regions of the world; the species was found during drilling in the Atlantic Ocean (Rio Grande Rise, Bahama Banks) and the Pacific Ocean (Shatsky Rise, Caroline Abyssal Plain, Hole 38 westwards of California).

The first rare specimens of $G$. aragonensis appear at the top of the Globorotalia formosa formosa Zone. In the upper part of the lower Eocene (the Globorotalia aragonensis Zone and the Globorotalia palmerae Zone in Bolli's sense), the species is abundant. Specimens of $G$. aragonensis are still common in basal layers of the middle Eocene and sporadic specimens also occur stratigraphically higher in the middle Eocene. For instance, in the USSR (North Caucasus) the last specimens of G. aragonensis have been found in the Hantkenina alabamensis Zone (=Orbulinoides beckmanni Zone).

\section{Globorotalia caucasica Glaessner}

(Plate 19, Figures 1-3)

1937. Globorotalia aragonensis var. caucasica Glaessner, p. 31, pl. 1, fig. 7 a-c.

Remarks: This species is most likely a descendant of Globorotalia aragonensis Nutt., being characterized by a wider and deeper umbilicus, ornamented umbilical ends of chambers that are turned to the side opposite from the umbilicus, a thicker keel covered with small spines, and a thick wall ornamented by tubercles and spines.

Globorotalia caucasica shows surprisingly convergent similarilty (homeomorphy) of morphological features with $G$. velascoensis (Cushm.), these being developed in deposits of various age. Globorotalia caucasica is characterized mostly by a thick wall supplied with tubercles, granules, and spines. Drawings of foraminifera fail to reflect the difference of these two species. However, a micropaleontologist familiar with typical representatives of $G$. caucasica and $G$. velascoensis, is unlikely to make a mistake identifying these species, as the difference between them can clearly be seen.

In the past, this morphological similarity has probably resulted in misidentifications especially for Paleogene deposits of countries in which either $G$. caucasica, or $G$. velascoensis is rare or absent.

For instance, in the upper Paleocene of the USSR (Crimea, North Caucasus) Globorotalia velascoensis (only low-conical specimens can be found) is sporadic or absent. This is very likely the reason that Subbotina (1953) and some other micropaleontologists erroneously report "Globorotalia velasoensis" from deposits of the Globorotalia aragonensis Zone (Lower Eocene) and the Acarinina bullbrooki Zone (middle Eocene).

In Egypt, the deposits of the Globorotalia aragonensis Zone (in a broad sense, including the Globorotalia palmerae Zone) are represented by hard limestone of the Thebes Formation. These rocks contain poor assemblages of planktonic foraminifera among which specimens of $G$. caucasica are rare and poorly preserved. This is likely the reason that El-Naggar (1966) considered G. caucasica Glaessen, as a subspecies of $G$. velascoensis Cushm. (upper Paleocene), not taking into account another stratigraphic level of development of true G. caucasica in the U.S.S.R.

In sections of calcareous Paleogene deposits of many countries it can clearly be seen that the stratigraphic ranges of Globorotalia velascoensis (upper Paleocene), G. aragonensis, and G. caucasica (the upper part of the lower Eocene-the lowermost part of the middle Eocene) are divided by a stratigraphic interval (the lowermost Eocene), where no high-conical Globorotalia occur. This fact testifies to the genetic independence of $G$. velascoensis and $G$. caucasica. The peculiarities of the stratigraphic distribution of $G$. velascoensis and G. caucasica were elucidated properly by Z. Reiss as far back as in 1957.

Globorotalia crater Finlay (1939, Trans, Roy. Soc. New Zeal., v. 69. pt; 1. p. 125) is a junior synonym of $G$ caucasica Glaessner, 1937. This species was described from lower Eocene deposits of New Zealand.

Jenkins (1971) regards $G$. causica as a subspecies of $G$. crater. He believes that $G$. crater causica differs from $G$, crater crater in having six to eight chambers in the final whorl as opposed to five in $G$. crater crater. However, the vast majority of specimens of $G$. caucasica from lower Eocene deposits of the North Caucasus have five chambers in the final whorl (less frequently their number increases up to 6).

Stratigraphic occurrence: Hole 200A, Core 2, top of the Globorotalia formosa formosa Zone (very rare specimens).

Stratigraphic and geographic range: The first sporadic specimens of $G$ caucasica appear at the top of the Globorotalia formosa formosa Zone. In the Globorotalia aragonensis Zone (in Bolli's sense), it is represented by rare specimens. It can frequently be observed in deposits of the Globorotalia palmerae Zone (lower Eocene) and the Hantkenina aragonensis Zone (middle Eocene). The last specimens of the species are known from sediments of the Globorotalia kulgeri Zone (in Bolli's sense).

The species is certain to be widely distributed geographically. However, discrepancies in understanding this species (caucasica, crater, "velascoensis") pose difficulties in enumerating its localities. Deep-sea drilling encountered $G$. caucasica in sediments of the upper part of the lower Eocene of the Atlantic Ocean (Rio Grande Rise) and the Pacific Ocean (Shatsky Rise, Caroline Abyssal Plain, Hole 38 to the west of California).

\section{Globorotalia naussi Martin \\ (Plate 26, Figures 1-3)}

1943. Globorotalia naussi Martin, p. 116, pl. 8 , fig. 3 a-c.

Remarks: The species was originally described from lower Eocene deposits of the Lodo Formation in California. As regards the shape of the test (conical test with a flat spiral side and strongly convex umbilical side, even peripheral margin), it is relatively similar to $G$. aragonensis Nutt. The characteristic features which distinguish $G$. naussi from $G$. aragonensis are a smaller test $(0.3-0.4 \mathrm{~mm}$ instead of 0.37-0.70 in G. aragonensis), a thinner wall, a smaller number of chambers in the final whorl (51/2-6 instead of 6-7 in G. aragonensis), and a thin glassy keel along the peripheral margin.

Stratigraphic occurrence: Hole $200 \mathrm{~A}$, Core 2, top of the Globorotalia formosa formosa Zone.

Stratigraphic and geographic range: Globorotalia naussi is associated with deposits of the Globorotalia aragonensis Zone (in a broad sense). Besides California, this species has been found in the USSR (North Caucasus) and in the Pacific Ocean (Shatsky Rise, Caroline Abyssal Plain).

\section{Globorotalia marksi Martin \\ (Plate 24, Figures 8-10)}

1943. Globorotalia marksi Martin, p. 115 , pl. 8 , fig. 1 a-c.

Remarks: A medium sized test $(0.40-0.50 \mathrm{~mm})$ of conical shape, spiral side slightly convex, the umbilical side strongly convex, almost inflated. In the last whorl, there are five to six inflated chambers, slowly increasing in size. The peripheral margin is subacute, without keel. The umbilicus is small but deep. The wall is thickened, covered by granules.

Globorotalia marksi is a surprisingly peculiar species, differing considerably from other species of planktonic formaninifera. The generic affinity of the species concerned is is open to question. Taking into account the absence of the keel, Sarbekyan (1964) described $G$. marksi from the Globorotalia aragonensis Zone of the North Caucasus as Acarinina marksi (Mart.).

Stratigraphic occurrence: Hole $200 \mathrm{~A}$, Core 2, top of the Globorotalia formosa formosa Zone (very rare specimens).

Stratigraphic and geographic range: The Globorotalia aragonensis Zone (lower Eocene) of the United States (California), USSR (North Caucasus), the Pacific Ocean (Shatsky Rise, Caroline Abyssal Plain). 
Globorotalia pseudoscitula Glaessner

(Plate 27, Figures 7-9)

1937. Globorotalia pseudoscitula Glaessner, p. 32 , text fig. 3 a-c; p. 33 , text fig. $3 \mathrm{~d}-\mathrm{f}$.

Remarks: Test small (diameter 0.2-0.3 mm), lenticular, compressed, spiral and umbilical sides almost uniformly convex. In the final whorl there are five to six chambers that are gradually increasing in size. Septal sutures are deepened, strongly curved, on the spiral side, and slightly lobate, almost even, acute, but without a keel, or with a very indistinct keel. The umbilicus is very small.

Stratigraphic occurrence: Hole 200A, Core 2, top of the Globorotalia formosa formosa Zone.

Stratigraphic and geographic range: Globorotalia pseudoscitula was initally described from lower Eocene deposits of theUSSR (North Caucasus). The species is ccommon in the Globorotalia aragonensis Zone and is found in subordinate numbers of specimens in the middle Eocene.

Globorotalia pseudoscitula has been recorded in the lower Eocene of the Atlantic Ocean (Rio Grande Rise) and the Pacific Ocean (Caroline Abyssal Plain).

\section{Globorotalia wilxcoxensis Cushman and Ponton (Plate 30, Figures 7-9)}

19332. Globorotalia wilcoxensis Cushman and Ponton, p. 71, pl. 9 , fig. $10 \mathrm{a}-\mathrm{c}$.

Remarks: The peripheral margin at the beginning of the final whorl is rounded; in the last two chambers it becomes angular, acute; sometimes a faint keel is present. The systematic position of the species is open to question-some micropaleontologists assign it to the genus Globorotalia ; others, to the genus Acarinina.

Stratigraphic occurrence: Hole 200A, Core 2, Globorotalia formosa formosa Zone (very rare specimens).

Stratigraphic and geographic range: Globorotalia wilcoxensis has been recorded in the lower Eocene of many countries: the United States (California, Gulf Coast), Trinidad, Cuba, Madagascar, India, Peru, Czechoslovakia, the USSR, Syria, Egypt, Iran, Cyprus, Yugoslavia, Morocco, etc. This species is characteristic of the Globorotalia subbotinae Zone; in the Globorotalia formosa formosa Zone, it is represented by very rare specimens.

\section{Globorotalia quetra Bolli}

(Plate 27, Figures 10-12)

\section{Globorotalia quetra Bolli, p. 79, pl. 19, figs. 1-6.}

Remarks: A very peculiar species planktonic foraminifera. It is characterized by an angular test (in the equatorial section), flat spiral side, strongly convex umbilical side, spiny keel on the peripheral margin that is especially distinct in early chamber of the final whorl, and a spinose wall or a wall covered with granules.

Presence of a spiny keel makes $G$. quetra different from $G$. wilcoxensis Cushm. and Pon., as well as from some species of Acarinina (A. triplex Subb., A. pseudotopilensis Subb., A. esnaensis LeRoy) that have a similar subsquare angular test.

Considerable resemblance can be seen between Globorotalia quetra and Truncorotaloides topilensis (Cushm.) from middle Eocene deposits, concerning shape of the test, arrangement of chambers, character of keel, and spinosity of the wall Truncorotaloides topilensis is characterized by supplementary sutural apertures on the spiral side of the test. However, in our materials from the lower Eocene of the Carolina Abyssal Plain, specimens of Globorotalia quetra, also with supplementary apertures on the spiral side of the test, occur frequently.

Globorotalia quetra and Truncorotaloides topilensis are certain to be two independent species developed in deposits of different age, just as is the case of Globorotalia velascoensis and G. caucasica. The surprising homeomorphy of morphological features of planktonic foraminifera is worth further study.

Some micropaleontologists assign Globorotalia quetra to the genus A carinina.

Stratigraphic occurrence: Hole 200A, Core 2, Globorotalia formosa formosa Zone (abundant specimens).

Stratigraphic and geographic range: Globorotalia quetra is indicative of lower Eocene deposits. The species appears in the upper part of the Globorotalia subbotinae Zone, is abundant in the
Globorotalia formosa formosa Zone, and can still be found in subordinate numbers of specimens in the Globorotalia aragonensis Zone (in Bolli's sense). This species occurs in Austria, Italy, Syria Senegal, Trinidad, Cuba and Australia in deposits of this age. It was also recorded during drilling in the Atlantic Ocean (Rio Grande Rise, Bay of Biscay) and the Pacific Ocean (Hole 38 off the west coast of California, Shatsky Rise, and the Caroline Abyssal Plain).

\section{Globorotalia troelseni Loeblich and Tappan} (Plate 29, Figures 4-6)

1957. Globorotalia troelseni Loeblich and Tappan, p. 196, pl. 60, fig. 4 a-c, pl. 63 , fig. 5 a-c.

Remarks: The low trochospiral test is laterally compressed with a lobulate equatorial profile. The final whorl contains five to six moderately inflated chambers which gradually increase in size. This whorl has a tendency to become uncoiled and, as a result, the test becomes evolute (initial whorls can be seen in the small umbilicus) The peripheral margin is subangular, narrowly rounded, with a thin keel (developed in early chambers of the last whorl). The surface of the wall is smooth and perforate.

Globorotalia troelseni differs from $G$. pseudomenardii Bolli in the evolute and uncoiled test, more inflated chambers, and a narrowly rounded peripheral margin.

Stratigraphic occurrence: Hole 200A, Core 2, Globorotalia formosa formosa Zone.

Stratigraphic and geographic range: The species was described for the first time from deposits of the Velasco and Nanafalia formations (Paleocene-lower Eocene) of the United States. Data on the stratigraphic and geographic distribution of $G$, troelseni are very poor. It appears rather worthwhile to establish the relation between G. troelseni and $G$. chapmani Parr, and G. elongata Glaessn. (the last two species are recorded from upper Paleocene sediments).

\section{Globorotalia apanthesma Loeblich and Tappan} (Plate 18, Figures 1-3)

1957. Globorotalia apanthesma Loeblich and Tappan, p. 187, pl. 48 , fig. 1 a-c, pl. 55, fig. 1 a-c, pl. 52, fig. 4 a-c, pl. 59 , fig. 1 a-c. Remarks: Test plano-convex, with a lobulate peripheral outline. Spiral side flat or slightly convex; umbilical side strongly convex in the shape of a truncated cone, with a deep and wide umbilicus. The final whorl consists of five chambers; their outlines on the spiral side are lunate and the sutures are strongly curved. The peripheral margin is supplied with a keel consisting of closely arranged spines, the glassy keel being absent. The surface of the test (especially on the umbilical side) is covered with short, closely arranged spines.

Morphologically, Globorotalia apanthesma differs rather considerably from other species of planktonic foraminifera obtained from Paleocene and lower Eooene sediments.

Some specimens of $G$. apanthesma from lower Eocene deposits of the Caroline Abyssal Plain possess supplementary apertures on the spiral side of the test, along the spiral suture.

Stratigraphic occurrence: Hole 200A, Core 2, Globorotalia formosa formosa Zone.

Stratigraphic and geographic range: The species was originally described from the Aquia, Vincentown, and Salt Mountain formations of the Gulf and Atlantic coastal plains (United States). These formations are attributed to the late Paleocene-Early Eocene. G. apanthesma is likely to appear in the upper part of the upper Paleocene, reaching its maximum development in the lowermost Eocene (the Globorotalia subbotinae and Globorotalia formosa formosa zones). In deposits of this age, the species is known (besides the United States) in the USSR, Syria, Egypt, New Zealand and the Pacific Ocean (Shatsky Rise, Caroline Abyssal Plain).

\section{Globorotalia aff. collactea Finlay (Plate 19, Figures 7-9)}

This form occurs as sporadic specimens which in the shape of their test resemble $G$. collactea of Bolli's (1957) interpretation. But Bolli's specimens are probably unrelated to $G$. collactea Finl., as it was shown by Jenkins $(1965,1971)$, that $G$. collactea is associated with younger deposits of the Paleogene of New Zealand (uppermost 
parts of the lower-middle Eocene) and is characterized by a spiny test wall (Jenkins assigns this species to the genus Truncorotaloides).

Stratigraphic occurrence: Hole 200A, Core 2, Globorotalia formosa formosa Zone.

\section{Acarina pentcamerata pentacamerata (Subbotina)}

(Plate 3, Figures 1-3)

1947. Globorotalia pentacamerata Subbotina, p. 128 , p. 7 , figs. 12-17, pl. 9, figs. 24-26.

Remarks: Test large (diameter $0.40-0.60 \mathrm{~mm}$ ), with a rounded equatorial profile and a slightly lobulate peripheral margin, dorsoventrally compressed. The last whorl has five to six spherical chambers, tightly coiled, that increase slowly in size as added. The spiral side is slightly convex; the umbilical side is convex with a wide umbilicus. The peripheral margin is rounded, sometimes a little angular, without a keel. The wall is covered with granules and spines. Spines in the umbilical part are thick and elongated.

Stratigraphic occurrence: Hole 200A, Core 2, top of the Globorotalia formosa formosa Zone. (common).

Stratigraphic and geographic range: Acarinina pentacamerata pentacamerata appears in the upper part of the Globorotalia formosa formosa Zone; this species is abundant in sediments of the upper part of the lower Eocene (the Globorotalia aragonensis Zone in a broad sense); it is still observed in subordinate numbers of specimens at the base of the middle Eocene (the Acarinina bullbrooki Zone), but here its descendant with seven to eight chambers in the final whorl, Acarinina aspensis is numerically dominant These two species of Acarinina seem generally to be regarded as unrelated.

In deposits of the given age, $A$. pentacamerata pentacamerata has been found in the USSR (Carpathians, Crimea, Caucasus), Bulgaria, Syria, Egypt, Yugoslavia, United States, (California), and during drilling in the Pacific Ocean (Shatsky Rise, Caroline Abyssal Plain). The authors describing Acarinina aspensis from deposits of the Globorotalia aragonensis Zone in Spain, on Trinidad, and in the Atlantic Ocean (Rio Grande Rise), seem to include Acarinina pentacamerata within the scope of this species.

\section{Acarinina penatacamerata camerata Khalilov}

(Plate 2, Figure 9-11)

1956. Acarinina pentacamerata camerata Khalilov, p. 252 , pl. 5 , fig. 6 a-c.

Remarks: This species differs from $A$. pentacamerata pentacamerata in an inflated spiral side.

Stratigraphic occurrence: Hole 200A, Core, Globorotalia formosa formosa Zone.

Stratigraphic and geographic range: A. pentacamerata camerata can be observed in large numbers in deposits of the lowermost Eocene (the Globorotalia subbotinae andd Globorotalia marginodentata zones) of the USSR (North Caucasus, Transcaspian, Transcaucasian, areas), and the Pacific Ocean (Shatsky Rise, Caroline Abyssal Plain).

\section{Acarinina broedermanni (Cushman and Bermudez)}

(Plate 1, Figures 4-6)

1949. Globorotalia broedermanni Cushman and Bermudez, p. 40, pl. 7 , figs. 22-24.

Remarks: This species can easily be distinguished from Acarinina pentacamerata (Subb.) by its biconvex test (the umbilical side is a little more convex), even equatorial outline, subangular peripheral margin, small umbilicus, convex initial whorls, and subangular chambers with a smooth surface on the spiral side.

Stratigraphic occurrence: Hole 200A, Core 2, Globorotalia formosa formosa Zone (common).

Stratigraphic and geographic range: Acarinina broedermanni is frequently found in lower Eocene deposits (from the Globorotalia subbotinae Zone to the Globorotalia aragonensis Zone) of the USSR, Syria, Egypt, Yugoslavia, Italy, Tunisia, Senegal, Trinidad, Cuba, United States, Pakistan, and New Zealand, as well as in the Atlantic Ocean (Rio Grande Rise) and the Pacific Ocean (Shatsky Rise, Caroline Abyssal Plain).

\section{Acarinina decepta (Martin)}

(Plate 1, Figures 7-9)

1943. Globigerina decepta Martin, p. 114, pl. 7, fig. 2a-c.

Remarks: This species is characterized by a subglobular test with an almost flat spiral side and strongly convex umbilical side; peripheral margin is rounded or bluntly angled, slightly lobulate in the equatorial section. The last whorl has 4 to $4 \frac{1}{2}$ chambers, tightly arranged. The umbilicus is very small. The surface is covered with spines.

A carinina decepta resembles $A$. interposita Subb. from deposits of the same age, being characterized by a strongly convex umbilical side, a small umbilicus, and tight arrangement of the chambers. These two species are worth studying in terms of their relationship to each other.

Stratigraphic occurrence: Hole 200A, Core 2, Globorotalia formosa formosa Zone.

Stratigraphic and geographic range: $A$. decepta was originally described from the Lodo Formation of California. This species has been recorded from lower Eocene deposits (the Globorotalia subbotinae Zone, Globorotalia aragonensis Zone) of the USSR (North Caucasus) and the Pacific Ocean (Shatsky Rise, Caroline Abyssal Plain).

Acarinina esnaensis (LeRoy)

(Plate 1, Figures 10-12)

1953. Globigerina esnaensis Leroy, p. 31, pl. 6, figs. 8-10.

Remarks: Test subsquare with a slightly convex spiral side and strongly convex umbilical side. Peripheral margin lobulate in equatorial profile, rounded, without keel. The last whorl consists of four chambers which rapidly increase in size. The first three chambers are rectangular and arcuate, the last one inflated and globular (on the spiral side). Umbilicus distinct. Wall covered by numerous spines (especially on the umbilical side).

Stratigraphic occurrence: Hole 200A, Core 2, Globorotalia formosa formosa Zone (very rare specimens).

Stratigraphic and geographic range: This species was originally described from the Esna shales, Farafra Oasis, Egypt, where it is indicative of the uppermost Paleocene (Globorotalia velascoensis Zone) and those of the lowermost Eocene (Globorotalia wilcoxensis Zone) (El-Naggar, 1966). Very rare specimens occur in sediments of the Globorotalia formosa formosa Zone of the Nile Valley.

In deposits of the given age, this species has been reported from Syria, Tunisia, the USSR, Denmark, France, United States, Pakistan, New Zealand, and other countries; it was also found during drilling in the Atlantic Ocean (Rio Grande Rise, Bay of Biscay) and the Pacific Ocean (Shatsky Rise, Caroline Abyssal Plain).

\section{Acarinina pseudotopilensis Subbotina}

(Plate 3, Figures 7-9)

1953. Acarinina pseudotopilensis Subbotina, p. 227, pl. 21, figs. $8 \mathrm{a}-\mathrm{c}, 9 \mathrm{a}-\mathrm{c}$, pl. 22, figs. 1a-c, 2a-c, 3a-c.

Remarks: This species resembles Acarinina esnaensis (LeRoy), being characterized by the following: the test is square or subsquare with clearly lobulate incised outline; the peripheral margin is narrowly rounded or bluntly angled, chambers are elongate and compressed, their ends lying beyond the general outline of the test; the last chamber is arranged at a right angle to the previous one.

Stratigraphic occurrence: Hole 200A, Core 2, Globorotalia formosa formosa Zone (very common).

Stratigraphic and geographic range: Acarinina pseudotopilensis is characteristic of deposits of the whole of the lower Eocene, thus having stratigraphic range different from that of $A$. esnaensis. $A$ carinina pseudotopilensis is certain to be widely distributed geographically. However, it is frequently regarded as a junior synonym of Acarinina esnaensis. Therefore, it is difficult to determine the areal distribution of $A$. pseudotopilensis.

During deep-sea drilling, $A$. pseudotopilensis was found in the Atlantic Ocean (Rio Grande Rise, the Labrador Sea) and the Pacific Ocean (Shatsky Rise, Caroline Abyssal Plain). 


\section{Acarinina triplex Subbotina}

(Plate 4, Figures 1-3)

1953, A carinina triplex Subbotina, p. 230 , pl. 23, figs. 1a,b,c-5a,b,c. Remarks: The test is strongly inflated, with a subsquare, weakly lobulate outline in equatorial profile and broadly rounded peripheral margin. Spiral side almost flat, umbilical side strongly inflated, sometimes hemisphaerical. Last whorl consists of 3 to $3 \frac{1 / 2}{2}$ tightly coiled chambers; their sizes increase quickly in the process of growth and the last chamber occupies $1 / 2$ of the whorl. Chambers are arranged at right angles to one another. They are elongate with oval contours (especially on the spiral side) and are separated by deep, almost straight sutures. The umbilicus is indistinct, very small. The surface of the wall is covered by numerous spines (especially on the umbilical side).

This species differs from Acarinina pseudotopilensis Subb. by its strongly inflated test, broadly rounded peripheral margin, more tight arrangement of chambers, and indistinct umbilicus. It is also distinguished from Acarinina esnaensis (LeRoy) by a quick increase in size of chambers as added, and elongate and fewer (3-31/2) chambers.

Stratigraphic occurrence: Hole 200A, Core 2, Globorotalia formosa formosa Zone (common).

Stratigraphic and geographic range: The first very rare specimens of A. triplex evidently appear in the Globorotalia subbotinae Zone (lowermost Eocene). This species is abundant in the remainder of the lower Eocene (Globorotalia formosa formosa Zone, Globorotalia aragonensis zone in a broad sense), passing into the basal layers of the middle Eocene (Acarinina bullbrooki Zone). In the sediments of this age, $A$. triplex has been found in the USSR, Bulgaria, Rumania, Syria, Yugoslavia, Egypt, United States (California), as well as in the process of drilling in the Atlantic ocean (Labrador Sea) and the Pacific ocean (Shatsky Rise, Caroline Abyssal Plain).

\section{Acarinina soldadoensis (Bronnimann)}

$$
\text { (Plate 3, Figures 10-12) }
$$

1952. Globigerina soldadoensis Bronnimann, p. 9, pl. 1, figs. 1-9.

Remarks: Rather large (diameter $0.45-0.60 \mathrm{~mm}$ ) tests of this species with five chambers in the last whorl resemble in some respects $A$ carinina pentacamerata (Subb.). They are distinguished by a more strongly inflated umbilical side, lobulate equatorial profile, a narrow, rounded, or even subangular peripheral margin, less tight arrangement of chambers, and subangular chamber form.

Stratigraphic occurrence: Hole 200A, Core 2, Globorotalia formosa formosa Zone (common).

Stratigraphic and geographic range: A. soldadoensis appears in the Globorotalia velascoensis Zone (uppermost Paleocene), is very common in the Globorotalia subbotinae and Globorotalia formosa formosa zones (lower part of the lower Eocene) and gradually disappears in the Globorotalia aragonensis Zone (upper lower Eocene). The geographic distribution of $A$. soldadoensis is very wide-Trinidad, United States (Gulf Coast, California), Nigeria, Pakistan, New Zealand, USSR, Czechoslovakia, Austria, Syria, Egypt, Cyprus, Italy, Spain, Tunisia, etc. This species has also been recorded through drilling by Glomar Challenger in the Atlantic Ocean (Rio Grande Rise, Labrador Sea, Bay of Biscay) and the Pacific Ocean (Caroline Abyssal Plain, Shatsky Rise, Hole 39 to the west of California).

\section{Acarinina gravelli (Bronnimann)}

(Plate 2, Figures 1-2)

1952. Globigerina gravelli Bronnimann, p. 12, pl. 1, figs. 16-18.

Remarks: This species has much in common with Acarinina mckannai (White), differing considerably in a larger test with lobulate outline, less compact arrangement of chambers, more inflated chambers, and a more concave initial part of the test. The stratigraphic intervals of $A$. gravelli and $A$. mckannai overlap, but the acmes of their development are different. Acarinina mckannai is abundant in deposits of the upper Paleocene; Acarinina gravelli, in the Globorotalia formosa formosa and Globorotalia aragonensis zones (lower Eocene).

Stratigraphic occurrence: Hole 200A, Core 2, Globorotalia formosa formosa Zone (common).
Stratigraphic and geographic range: Acarinina gravelli is known from the lower Eocene of Trinidad, Cuba, United States, Senegal, USSR, Syria, Italy, Spain and the Pacific Ocean (Shatsky Rise, Caroline Abyssal Plain).

\section{Chiloguembelina wilcoxensis (Cushman and Ponton)}

(Plate 5, Figures 2-3)

1932. Guembelina wilcoxensis Cushman and Ponton, p. 66, pl. 8, figs. 16,17 .

Remarks: This species is characterized by a large test (length up to $0.45-0.60 \mathrm{~mm}$ ), with inflated subglobular chambers and semicircular symmetrical aperture.

Stratigraphic occurrence: Hole 200A, Core 2, Globorotalia formosa formosa Zone.

Stratigraphic and geographic range: Chiloguembelina wilcoxen: sis has been determined from the lower Eocene of the United States (Alabama) and upper Paleocene-lower Eocene (Globorotalia formosa formosa Zone) sediments of Trinidad. The occurrence of this species in the Pacific Ocean (Caroline Abyssal Plain) testifies to its wide geographic distribution.

\section{Chiloguembelina parallela Beckmann} (Plate 4, Figures 10-11)

1957. Chiloguembelina parallela Beckmann, p. 91, pl. 21, fig. 8, text-fig. 15(36-38).

Remarks: The most characteristic feature of this species is a high, narrow and symmetrical aperture bordered by two parallel lateral flanges.

Stratigraphic occurrence: Hole 200A, Core 2, Globorotalia formosa formosa Zone.

Stratigraphic and geographic range: J. Beckmann (1957), describing $C h$. parallela, mentioned its restricted stratigraphic range-the Globorotali rex Zone, lower Eocene of Trinidad. Actually, the range of this species is longer because in the Caroline Abyssal Plain it was found in sediments of the Globorotalia formosa formosa Zone.

\section{Globigerina taroubaensis Bronnimann}

(Plate 11, Figures 4-6)

1952. Globigerina taroubaensis Bronnimann, p. 18, pl. 2, figs. 16-18.

Remarks: This species of Globigerina is identical in morphology to G. taroubaensis described by P. Bronnimann (1952) and H. Bolli (1957) from sediments of the Globorotalia aragonensis Zone (lower Eocene) of Trinidad.

Stratigraphic occurrence: Hole 200A, Core 2, top of Globorotalia formosa formosa Zone.

Stratigraphic and geographic range: Apart from Trinidad and the Caroline Abyssal Plain, Globigerina taroubaensis has been found in undifferentiated sediments of the Globorotalia aragonensisGloborotalia formosa formosa zones of the Rio Grande Rise (Atlantic Ocean), and in Pakistan.

\section{Globigerina prolata Bolli}

(Plate 10, Figures 2-3)

1957. Globigerina prolata Bolli, p. 72 , pl. 15, figs. 24-26.

Remarks: Test low trochospiral with 4 to $4 \frac{1}{2}$ globular chambers in the last whorl which increase rapidly in size as added. Contour of the test in equatorial profile is elongate, lobulate, with the peripheral margin rounded. Surface smooth. The aperture opens in the umbilicus or is umbilical-extraumbilical.

Stratigraphic occurrence: Hole 200A, Core 2, top of Globorotalia formosa formosa Zone.

Stratigraphic and geographic range: Globigerina prolata was originally described from the lower Eocene of Trinidad (the Globorotalia formosa formosa and Globorotalia aragonensis zones of Bolli): Globigerina prolata is recorded in sediments of this age in Italy, Syria, Cuba, and the Pacific Ocean (Shatsky Rise, Caroline Abyssal Plain). 
Middle Eocene

\section{Orbulinoides beckmanni (Saito)}

(Plate 31, Figure 12)

1962. Porticulasphaera beckmanni Saito, p. 221, pl. 34, figs. 1a-2. Stratigraphic occurrence: Hole 202, Core 2, Orbulinoides beckmanni Zone.

Stratigraphic and geographic range: This well known species with a short stratigraphic range has been found in the middle Eocene of many tropical and subtropical areas (Caribbean, Mediterranean, Senegal, Mexico, Tanzania, Pakistan, Australia, Japan, etc.), as well as during drilling in the Atlantic Ocean (Holes $10,108,144$ in the northern part and Hole 19 in the southern part) and the Pacific Ocean (Horizon Rise-Holes 44, 171, Caroline Abyssal Plain). Evidently, it is less abundant in more northerly regions. For example, in the southernmost USSR (Transcaucasian Armenia), Orbulinoides beckmanni is represented by very rare specimens and in the middle Eocene of the North Caucasus it is not found.

\section{Globigerapsis kugleri Bolli, Loeblich and Tappan}

(Plate 5, Figures 6-7)

1957. Globigerapsis kugleri Bolli, Loeblich and Tappan, p. 34, pl. 6, fig. $6 \mathrm{a}-\mathrm{b}$.

Remarks: In sediments of the middle Eocene, G. kugleri is usually associated with $G$. index (Finlay), differing in a larger final chamber covering the umbilicus, low-arched supplementary apertures along the spiral suture, and a more tightly coiled test.

Stratigraphic occurrence: Hole 202, Core 2, Orbulinoides beckmanni Zone.

Stratigraphic and geographic range: This species is widely distributed in the middle Eocene (Globigerapsis kugleri Zone-Orbulinoides beckmanni Zone) of many regions of the world (Caribbean, Mediterranean, Middle East, Senegal, etc.) and has also been found in the Atlantic Ocean (Rio Grande Rise) and the Pacific Ocean (Horizon Rise, Caroline Abyssal Plain). Apparently, its geographic range is more limited as compared to that of Globigerapsis index. For instance, it is absent in the middle Eocene of the North Caucasus where Globigerapsis index is exceedingly abundant.

\section{Globigerapsis index (Finlay) \\ (Plate 5, Figures 4-5)}

1939. Globigerinoides index Finlay, p. 125, pl. 14, figs. 85-88.

Stratigraphic occurrence: Hole 202, Core 2, Orbulinoides beckmanni Zone.

Stratigraphic and geographic range: This species has a very long stratigraphic range, nearly all of the middle and upper Eocene; it is recorded in many regions of the world including the Caribbean, Mediterranean, Middle East, USSR, Bulgaria, Poland, Roumania, Czechoslovakia, West Germany, Pakistan, New Zealand, Australia, Solomon Islands, Indonesia, and the Mariana Islands, as well as in many holes in the Atlantic Ocean $(6,10,14,19,20,98,112,116$, $117)$ and the Pacific Ocean $(44,171,202)$.

\section{Globigerinatheka barri Bronnimann} (Plate 12, Figures 4-5)

1952. Globigerinatheka barri Bronnimann, p. 27, text fig. 3a.

Stratigraphic occurrence: Hole 202, Core 2, Orbulinoides beckmanni Zone.

Stratigraphic and geographic range: Globigerinatheka barri appears in the Globigerapsis kugleri Zone (middle Eocene) and disappears in the lower part of the upper Eocene. In sediments of this age, $G$. barri has been recognized in many countries of the Caribbean region, Mediterranean, Middle East, Poland, Czechoslovakia, Switzerland, Senegal, Pakistan, New Zealand, Philippines, Japan, etc., and also in the Atlantic (Holes 19, 98, 144) and Pacific (Holes 44, 171, 202) oceans.

\section{Globigerina pseudoeocaena Subbotina} (Plate 10, Figures 4-6)

1953. Globigerina pseudoeocaena Subbotina, p. 66, pl. 4, fig. 9a-c, pl. 5 , figs. $1 \mathrm{a}, \mathrm{b}, \mathrm{c}-6 \mathrm{a}, \mathrm{b}, \mathrm{c}$
Remarks: Test large (diameter $0.40-0.65 \mathrm{~mm}$ ), with strongly lobate outline and concave initial whorls. The final whorl consists of four inflated, almost globular chambers. They are loosely connected, rapidly increase in size as added. As a result, the test is elongate in the direction of growth. The peripheral margin is broadly rounded. The umbilicus is deep. Septal sutures are depresse $A$, and straight. The surface is roughly porous, and cancellate.

Stratigraphic occurrence: Hole 202, Core 2, Orbulinoides beckmanni Zone.

Stratigraphic and geographic range: Globigerina pseudoeocaena is abundant in the lower Eocene (Globorotalia aragonensis Zone) and the middle Eocene of the USSR (Carpathians, Crimea, Caucasus, Transcaspian); reported from Bulgaria, Poland, Rumania, Czechoslovakia, Syria, Yugoslavia, Tunisia, Egypt, United States (California) and the Pacific Ocean (Shatsky Rise, Caroline Abyssal Plain).

\section{Globogerina pseudovenezuelana Blow and Banner} (Plate 10, Figures 7-8)

1962. Globigerina yeguaensis pseudovenezuelana Blow and Banner, p. 100 , pl. XI, figs. J-L,N,O.

Stratigraphic occurrence: Hole 202, Core 2, Orbulinoides beckmanni Zone.

Stratigraphic and geographic range: This species appears (as rare specimens) in the Orbulinoides beckmanni Zone (middle Eocene) and disappears in the lower Oligocene. G. pseudovenezuelana has usually been included within the scope of $G$. venezuelana, $G$. pseudoeocaena, G. yeguaensis, etc. Therefore, the geographic distribution of the sepcies remains unknown, but it is evidently very wide: Trinidad, Tanzania, USSR, Syria, Pacific Ocean (Shatsky Rise, Caroline Abyssal Plain).

\section{Globigerina galavisi Bermudez}

(Plate 8, Figures 3-5)

1961. Globigerina galavisi Bermudez, p. 183 , pl. 4 , fig. 3 .

Remarks: The specimens observed are similar to G. galavisi, in the sense of Bermudez (1961) and Blow (1969) and G. yeguaensis, as interpreted by Blow and Banner (in Eames et al., 1962).

Stratigraphic occurrence: Hole 202, Core 2, Orbulinoides beckmanni Zone.

Stratigraphic and geographic range: the species appears in deposits of the Orbulinoides beckmanni Zone (middle Eocene) and disappears in the Globorotalia opima Zone (middle part of the Oligocene). In the deposits of this age, the species has been recorded in the USSR, Syria, Tanzania, United States (Gulf Coast), Trinidad, the Atlantic Ocean (Rio Grande Rise, Labrador Sea, Rockall Basin) and the Pacific Ocean (to the west of California, Horizon Rise, the western termination of the Clipperton Fracture Zone, and the area northward of this zone).

\section{Globorotalia centralis Cushman and Bermudez} (Plate 19, Figures 4-6)

1937. Globorotalia centralis Cushman and Bermudez, p. 26, pl. 2, figs. 62-65.

Remarks: Toumarkine and Bolli (1970), studying topotypical specimens of $G$. centralis Cushm. and Berm., considered this species a synonym of $G$. cerroazulensis cerroazulensis (Cole), though the latter is characterized by compressed chambers, a narrowly rounded peripheral margin, flange-like chambers and curved septal sutures on the spiral side of the test. So, if the above observations of Toumarkine and Bolli are correct, the species concerned appears to be named $G$, pomeroli Toum. and Bolli.

Geographical occurrence: Hole 202, Core 2, Orbulinoides beckmanni Zone (abundant).

Stratigraphic and geographic range: The species described (whether its specific term is correct or not) appears in great numbers of specimens at the base of the Orbulinoides beckmanni Zone, gradually decreasing in the Truncorotaloides rohri Zone (middle Eocene). In the upper Eocene, it is observed in subordinate numbers. In deposits of this age, the species has been recorded in many countries of Europe, Asia, Africa, America, Australia, as well as in the Atlantic and Pacific oceans through drilling by the Glomar 
Challenger. However, it is not certain whether the scope of this species is interpreted uniformly.

\section{Globorotalia spinulosa Cushman}

(Plate 28, Figures 7-9)

1927. Globorotalia spinulosa Cushman, p. 114, pl. 23, fig. 4 .

Remarks: This species differs from the similar G. lehneri Cushm. and Jarv. in a less compressed lens-like test, truncated conical umbilical side, flange-like chambers, lobulate peripheral margin, and glassy thickenings along the septal sutures on the spiral side.

Stratigraphic occurrence: Hole 202, Core 2, Orbulinoides beckmanni Zone.

Stratigraphic and geographic range: Globorotalia spinulosa appears at the base of the middle Eocene and disappears in its upper part (in basal layers of the Truncorotaloides rohri Zone). In deposits of this age, the species has been found in the Mediterranean (Syria, Yugoslavia, Italy, Spain), countries of Africa (Morocco, Senegal, Tanzania), the Caribbean area (Cuba, Trinidad, Barbados), United States, Mexico, Pakistan, Australia, USSR, the Atlantic Ocean (Rio Grande Rise, the east coast of North America-Hole 108 and South America-Hole 144) and the Pacific Ocean (Horizon Rise, Ontong Java Plateau).

\section{Globorotalia lehneri Cushman and Jarvis} (Plate 23, Figures 7-9)

1929. Globorotalia lehneri Cushman and Jarvis, p. 17, pl. 3, fig. 16 . Stratigraphic occurrence: Hole 202, Core 2, Orbulinoides beckmanni Zone.

Stratigraphic and geographic range: The species is widely distributed in deposits of the Globorotalia lehneri Zone and disappears at the top of the middle Eocene. It is recorded in many countries of the Mediterranean (Syria, Yugoslavia, Italy, Spain), Africa (Senegal, Tanzania), Asia (Iran, Japan), the Caribbean (Cuba, Trinidad), United States, Mexico, the Atlantic Ocean (Bermuda Rise, Rio Grande Rise) and the Pacific Ocean.

\section{Truncorotaloides topilensis (Cushman)} (Plate 35, Figures 4-6)

1925. Globigerina topilensis Cushman, p. 7, pl. 1, fig. 9.

Stratigraphic occurrence: Hole 202, Core 2, Orbulinoides beckmanni Zone.

Stratigraphic and geographic range: The species is frequently observed in the deposits of the Globorotalia lehneri and Orbulinoides beckmanni zones (middle Eocene). The geographical distribution of the species is wide: FRG, Bulgaria, USSR, Syria, Iran, Yugoslavia, Italy, Morocco, Senegal, Trinidad, Barbados, Mexico, New Zealand, Japan, Pakistan, the Atlantic Ocean (Rio Grande Rise, Bahama Banks) and the Pacific Ocean (Horizon Rise).

\section{Truncorotaloides rohri Bronnimann and Bermudez} (Plate 31, Figures 1-3)

1953. Truncorotaloides rohri Bronnimann and Bermudez, p. 818 , pl. 87 , figs. 7-9.

Stratigraphic occurrence: Hole 202, Core 2, Orbulinoides beckmanni Zone.

Stratigraphic and geographic range: The first specimens of $T$. rohri appear in the lower part of the middle Eocene; the species is rather peculiar to the deposits of the Globorotalia lehneri, Orbulinoides beckmanni, and Truncorotaloides rohri zones. It is known from the middle Eocene of the Mediterranean region, Caribbean, Africa (Tanzania, Senegal), the Atlantic Ocean (Bermuda Rise, Rio Grande Rise, Bahama Banks, the eastern coast of South America-Hole 144) and the Pacific Ocean (Horizon Rise).

\section{Hantkenina alabamensis Cushman}

(Plate 31, Figures 3, 6)

1924. Hantkenina alabamensis Cushman, p. 3, pl. 1, figs. 1-6, pl. 2 , fig. 5 .

Stratigraphic occurrence: Hole 202, Core 2, Orbulinoides beckmanni Zone.

Stratigraphic and geographic range: The species is representative of deposits of the Orbulinoides beckmanni Zone (middle Eocene).
In the stratigraphic scale of the USSR Paleogene (the CrimeanCaucasian regions), equivalent deposits are distinguished as the Hantkenina alabamensis Zone. In the sediments of younger age (Truncorotaloides rohri Zone of the middle and upper Eocene), the species becomes less frequent. Geographically, $H$. alabamensis is cosmopolitan; it occurs in Europe (USSR, Bulgaria, Yugoslavia, Italy, Spain), Asia (Syria, Cyprus, Afganistan, the Philippines), Africa (Morocco, Tanzania), America (United States, Mexico, Panama, Ecuador, Peru), as well as in New Zealand, Australia, Cuba, Trinidad, and the Dominican Republic. Deep-sea drilling found this species in the Atlantic Ocean (Rio Grande Rise, Bahama Banks) and the Pacific Ocean (Horizon Rise).

\section{NEOGENE}

Deep Sea Drilling holes penetrate Neogene deposits considerably more often than sediments of older age. Therefore, the biostratigraphy of Neogene planktonic foraminifera is fairly well known. Some of the "Initial Reports of the Deep Sea Drilling Project" contain numerous plates of planktonic foraminifera and more or less detailed comments on these species (Volumes IV, XI and XII of the "Initial Reports..." for the Atlantic Ocean and Volumes VII and IX for the Pacific Ocean). These publications show that many of the Neogene species are interpreted uniformly; therefore, the remarks given below on Neogene planktonic foraminifera will be brief.

Lower Miocene

$$
\begin{gathered}
\text { Globigerina angustiumbilicata Bolli } \\
\text { (Plate 5, Figures 8-10) }
\end{gathered}
$$

1957. Globigerina ciperoensis angustiumbilicata Bolli, p. 109, pl. 22, figs. 12-13.

Stratigraphic occurrence: Hole 200, Cores 9 and 10, upper part of Globigerinita stainforthi Zone, Praeorbulina glomerosa Zone.

Stratigraphic and geographic range: The species appears at the top of the upper Eocene and is widely developed in Oligocene and lower Miocene deposits. In sediments of younger age, it is sporadic. The species has been recorded in many countries of the Caribbean region, the Mediterranean, and the Atlantic and Pacific oceans.

\section{Globigerina praebulloides Blow \\ (Plate 9, Figures 10-12)}

1959. Globigerina praebulloides Blow, p. 180 , pl. 8 , fig. 47 , pl. 9 , fig. 48.

Stratigraphic occurrence: Hole 200, Cores 9 and 10, upper part of Globigerinita stainforthi Zone, Praeorbulina glomerosa Zone.

Stratigraphic and geographic range: The species appears in the upper part of the middle Eocene and evidently disappears in the lowermost part of the upper Miocene (Tortonian Stage). Its distribution is cosmopolitan.

\section{Globigerina juvenilis Bolli} (Plate 8, Figure 6)

1957. Globigerina juvenilis Bolli, p. 110, pl. 24, figs. 5-6.

Stratigraphic occurrence: Hole 200, Core 10 (upper part of Globigerinita stainforthi Zone, abundant), Cores 9 and 10 (Praeorbulina glomerosa Zone, rare).

Stratigraphic and geographic range: The species is abundant in deposits of the lower part of the lower Miocene (Globorotalia kugleri, Globigerinita stainforthi zones); in the upper part of the lower Miocene, specimens of $G$. juvenilis are less numerous; in the middle and upper Miocene, it is sporadic. The species has been recorded from the Miocene of many countries of the Caribbean region, Mediterranean and the Atlantic and Pacific oceans.

\section{Globigerina bradyi Wiesner}

$$
\text { (Plate 6, Figures 7-8) }
$$

1901-1903. Globigerina bradyi Wiesner; see Bolli, 1957, p. 110, pl. 23 , fig. 5 .

Stratigraphic occurrence: Hole 200, Core 10 (upper part of Globigerinita stainforthi Zone, abundant), Cores 9 and 10 (Praeorbulina glomerosa Zone, very rare). 
Stratigraphic and geographic range: Globigerina bradyi is peculiar to deposits of the lowermost Miocene (Globorotalia kugleri, Globigerinita stainforthi zones); in the upper part of the lower Miocene, the species is represented by sporadic specimens. Globigerinids with a high-conical test are also found in upper Miocene, Pliocene, and Quaternary sediments. Their relationship with lower Miocene $G$. bradyi remains obscure. It is very likely that they belong to different species. Globigerina bradyi Wiesner should be used for Quaternary and late Neogene globigerinids, whereas, the high-conical lower Miocene " $G$. bradyi" requires a new specific name.

"Globigerina bradyi," as presently interpreted, has been recognized from the lower Miocene of many regions of the world.

\section{Globigerina binaiensis Koch}

(Plate 6, Figures 1-3)

1935. Globigerina binaiensis Koch; nom. nov. for Globigerina aspere Koch, 1926 , p. 746 , figs. 22-23.

Stratigraphic occurrence: Hole 200, Core 10 (upper part of Globigerinita stainforthi Zone), abundant.

Stratigraphic and geographic range: Specimens of $G$. binaiensis from the lower Miocene of the Caroline Abyssal Plain are similar to illustrations of this species given by Koch (1926) and Blow (1969) of specimens from the lower Miocene of Kalimantan Island. According to Blow (1969), this species with peculiar morphological features is characterized by a narrow stratigraphic range (Globigerina angulisuturalis Zone, upper Oligocene to Globoquadrina dehiscens praedehiscens Zone, lower Miocene) and is distributed within the Indo-Pacific area only. It appears that the stratigraphic range of $G$. binaiensis is somewhat longer; in the Caroline Abyssal Plain cores, this species was found in sediments of younger age (Globigerinatella insueta-Globigerinita dissimilis Zone according to Blow's zonal scheme, or Globigerinita stainforthi Zone of Bolli's scheme). It does not occur, however, in the basal layers of the Praeorbulina glomerosa Zone (upper part of the Burdigalian Stage). Unfortunately, sediments of an intermediate age (Globigeri. natella insueta-Globigerinoides trilobus Zone, lower part of the Burdigalian Stage) in Hole 200 are poorly defined and it was not possible to establish the true level of disappearance of $G$. binaiensis.

\section{Globigerina venezuelana Hedberg}

(Plate 12, Figures 1-2)

1937. Globigerina venezuelana Hedberg, p. 681, pl. 92, fig. 7.

Stratigraphic occurrence: Hole 200, Core 10, upper part of Globigerinita stainforthi Zone, rare; Cores 9 and 10 Praeorbulina glomerosa Zone, very rare.

Stratigraphic and geographic range: The species appears at the top of the Oligocene (Globigerina angulisuturalis Zone), is abundant in sediments of the lowermost Miocene (Globorotalia kugleri Zone, Globigerinita stainforthi Zone) and occurs rarely in planktonic foraminiferal assemblages of the upper part of the lower Miocene. It is sporadic in the middle and upper Miocene. The data presented by some authors about the presence of $G$. venezuelana in middle-upper Miocene deposits require additional study. The species has a cosmopolitan distribution in the Miocene of the tropical, subtropical, and probably temperate areas.

\section{Globigerina falconensis Blow (Plate 7, Figures 9-11)}

1959. Globigerina falconensis Blow, p. 177, pl., fig. 40-41

Stratigraphic occurrence: Hole 200, Core 10, upper part of Globigerinita stainforthi Zone, comparatively rare specimens; Cores 9 and 10 Praeorbulina glomerosa Zone, common.

Stratigraphic and geographic range: the species is common in deposits of the upper part of the lower Miocene (Burdigalian Stage), subordinate in the middle Miocene, and probably disappears in the lower part of the upper Miocene (Tortonian Stage). It has a wide geographic distribution.

\section{Globigerina bollii Cita and Premoli Silva \\ (Plate 6, Figures 4-6)}

1960. Globigerina bollii Cita and Premoli Silva, p. 119, pl. 13, figs. $1-18$, text-fig. 1 .
Remarks: Blow (1969) believes that $G$. bollii, 1960, is a junior synonym of $G$. falconensis, 1959. However, the species concerned is characterized by subquadrate test outline, a tight arrangement of chambers, slight increase of chamber size as added, and large test size.

Stratigraphic occurrence: Hole 200, Core 10, upper part of Globigerinita stainforthi Zone, very rare specimens.

Stratigraphic and geographic range: In the Mediterranean, the species is common in deposits of the lower part of the Burdigalian Stage (the Globigerinatella insueta-Globigerinoides trilobus Zone), is frequently found in its upper half (Praeorbulina glomerosa Zone), and becomes sporadic in the middle Miocene (sediments with Orbulina suturalis). The geographic range of the species is poorly known, though $G$, bollii has been recorded in the Miocene of the Atlantic and Pacific oceans.

\section{Globigerinoides trilobus (Reuss) \\ (Plate 15, Figures 6-9)}

1850. Globigerina triloba Reuss, p. 374 , pl. 47 , fig. 11 .

Stratigraphic occurrences: Hole 200, Cores 1-7, 9, 10, lower Miocene-Quaternary; Hole 202, Core 1, Pliocene.

Stratigraphic and geographic range: The species is highly variable and is characterized by wide stratigraphic and geographic distribution. Rare specimens of $G$. trilobus trilobus can be found in the upper part of the Aquitanian Stage (Globigerinita dissimilis and Globigerinita stainforthi zones of Bolli's zonal scheme); abundant specimens of $G$. trilobus trilobus occur beginning from the Burdigalian Stage (the Globigerinatella insueta-Globigerinoides trilobus Zone of Blow's scheme).

\section{Globigerinoides subquadratus Bronnimann (Plate 15, Figures 3-5}

1954. Globigerinoides subquadratus Bronnimann, p. 680 , pl. 1, fig. 5 .

Stratigraphic occurrence: Hole 200, Cores 9, 10, upper part of Globigerinita stainforthi Zone, Praeorbulina glomerosa Zone, lower Miocene, common; Cores 6, 7, Globorotalia continuosa Zone and Globorotalia acostaensis-Globorotalia merotumida Zone, upper Miocene, very rare specimens.

Stratigraphic and geographic range: The species is representative of deposits of the Burdigalian Stage (lower Miocene), being frequently observed in middle Miocene sediments also. In the lower part of the upper Miocene (Tortonian Stage), specimens of $G$. subquadratus are sporadic and somewhat different from typical forms of this species.

\section{Globigerinoides diminutus Bolli (Plate 13, Figure 9)}

1957. Globigerinoides diminuta Bolli, p. 114, pl. 25, fig. 11.

Stratigraphic occurrence: Numerous specimens of this very peculiar species were seen in Hole 200, Core 9, Praeorbulina glomerosa Zone.

Stratigraphic and geographic range: The species is typical for the Burdigalian Stage (Globigerinatella insueta Zone in Bolli's sense). According to Bolli (1957), the species is found mostly in the lower part of this zone. However, in the Caroline Abyssal Plain material, G. diminutus is also found in the upper part of the Globigerinatella insueta Zone. The species probably disappears in the basal layers of the middle Miocene.

\section{Globigerinoides sicanus De Stefani \\ (Plate 15, Figures 1-2)}

1950. Globigerinoides sicanus De Stefani, v. 3, note 4, p. 9.

Stratigraphic occurrence: Hole 200, Cores 9, 10, Praeorbulina glomerosa Zone, lower Miocene (abundant) and Globorotalia peripheroronda Zone, middle Miocene (sporadic).

Stratigraphic and geographic range: The distribution of $G$. sicanus in the Miocene sediments of Hole 200 reflects the entire stratigraphic range of this species (upper part of the Burdigalian Stage, lower Miocene to basal layers of the middle Miocene). Distribution cosmopolitan. 
Globigerinoides mitra Todd

(Plate 14, Figures 1-2)

1956. Globigerinoides mitra Todd, p. 302, pl. 78, figs. 3, 6 .

Stratigraphic occurrence: Hole 200, Cores 9, 10, Praeorbulina glomerosa Zone, numerous specimens.

Stratigraphic and geographic range: The stratigraphic range of G. mitra in the area of the Atlantic and Pacific oceans covers almost the whole Miocene. The species is worth thorough study. It may prove heterogenous.

\section{Globoquadrina praedehiscens Blow and Banner}

(Plate 17, Figures 1-3)

1962. Globoquadrina dehiscens praedehiscens Blow and Banner, pl. 116 , pl. 15, figs. Q-S.

Stratigraphic occurrence: Hole 200, Core 10, upper part of Globigerinita stainforthi Zone, very rare specimens.

Stratigraphic and geographic range: The species is very characteristic for the deposits of the lower part of the lower Miocene (Aquitanian Stage, Globorotalia kugleri Zone to Globigerinita stainforthi Zone). The first specimens seem to appear in the top of the upper Oligocene. It has been recorded in the Aquitanian Stage in many countries of the Mediterranean region, the Caribbean region and the areas of the Atlantic and Pacific oceans.

\section{Globoquadrina dehiscens (Chapman, Parr, and Collins)} (Plate 16, Figures 4-6)

1934. Globorotalia dehiscens Chapman, Parr, and Collins, p. 569, pl. 11 , fig. 36

Stratigraphic occurrence: Hole 200, Core 10, upper part of Globigerinita stainforthi Zone (sporadic specimens); Cores 3-7, 9, 10, Praeorbulina glomerosa Zone, lower Miocene through the Sphaeroidinella dehiscens-Globoquadrina altispira Zone, lower Pliocene (common in many samples). Hole $200 \mathrm{~A}$, Core 1, and Hole 202, Core 1, lower Pliocene.

Stratigraphic and geographic range: This cosmopolitan species has a wide stratigraphic range; considerable numbers of specimens of $G$. dehiscens are found in deposits of the Burdigalian Stage, lower Miocene through the lower Pliocene. Rare specimens of $G$. dehiscens appear in the upper part of the Aquitanian Stage, lower Miocene.

\section{Globoquadrina altispira (Cushman and Jarvis)}

(Plate 15, Figures 10-12)

1936. Globigerina altispira Cushman and Jarvis, p. 5, pl. 1, figs. 13, 14.

Stratigraphic occurrence: In Holes 200, 200A, and 202, G. altispira has the same stratigraphic range as $G$. dehiscens.

Stratigraphic and geographic range: Sporadic specimens of $G$. altispira are known from deposits of the Aquitanian Stage (the Globorotalia kugleri to Globigerinita stainforthi zones). Great numbers of specimens appear beginning from the base of the Globigerinatella insueta Zone of Bolli's zonal scheme (Burdigalian Stage); it disappears in the middle part of the Pliocene, at the lower boundary of the Globorotalia tosaensis Zone (upper Pliocene). The distribution is cosmopolitan.

\section{Globoquadrina larmeui obesa Akers} (Plate 16, Figures 10-12)

1955. Globoquadrina obesa Akers, p. 661, pl. 65 , fig. 5 .

Stratigraphic occurrence: Hole 200, Core 9, Praeorbulina glomerosa Zone, rare specimens.

Stratigraphic and geographic range: According to Blow (1969), the stratigraphic range of $G$. larmeui obesa covers the Praeorbulina glomerosa Zone (Burdigalian Stage, early Miocene) through the Sphaeroidinella dehiscens-Globoquadrina altispira Zone (early Pliocene).

\section{Globoquadrina baroemoenensis (LeRoy)}

(Plate 16, Figures 1-3)

1939. Globigerina baroemoenensis LeRoy, p. 263, pl. 6, figs. 1-2.

Stratigraphic occurrence: Hole 200, Core 10, upper part of Globigerinita stainforthi Zone, numerous specimens; Cores 9 and 10, Praeorbulina glomerosa Zone, lower Miocene, and Globorotalia
peripheroronda-Orbulina Suturalis Zone, middle Miocene, very rare specimens.

Stratigraphic and geographic range: The species is poorly known in the micropaleontological literature. It was originally described from the Miocene of Indonesia, and observed in some countries of the Caribbean area. According to Blow (1969), the species is characterized by a long stratigraphic range: from the Globorotalia opima Zone (middle part of the Oligocene) up to the Globorotalia acostaensis-Globorotalia merotumida Zone (Tortonian Stage, upper Miocene).

\section{Globoquadrina langhiana Cita and Gelati} (Plate 16, Figures 7-9)

1960. Globoquadrina langhiana Cita and Gelati, p. 241, pl. 29, fig. $1-20$

Stratigraphic occurrence: Hole 200, Cores 9 and 10, Praeorbulina glomerosa Zone, lower Miocene, common; Globorotalia peripheroronda-Orbulina suturalis Zone, middle Miocene, very rare.

Stratigraphic and geographic range: Globoquadrina langhiana is developed in the deposits of the upper part of the lower Miocene (Burdigalian Stage) and middle Miocene. The species was originally described from the deposits of the Langhian Stage of Italy. Its occurrence in the Clifdenian and Lillburnian stages of New Zealand (Jenkins, 1971) testifies to a wide geographical distribution of $G$. langhiana.

Blow (1969) considers that $G$. langhiana is a synonym (or subspecies) of $G$. baroemoenensis (LeRoy). However, the former is characterized by an oval test outline in equatorial profile (in $G$. baroemoenensis the test is approximately subquadrate), more globular chambers, the rounded shape of the apertural face, and a weakly developed umbilical tooth. Therefore, $G$. langhiana is here regarded as a separate species.

\section{Cassigerinella chipolensis (Cushman and Ponton) (Plate 4, Figures 7-9)}

1932. Cassidulina chipolensis Cushman and Ponton, p. 98, pl. 15, fig. 2 .

Stratigraphic occurrence: Hole 200, Cores 9 and 10, upper part of Globigerinita stainforthi Zone and Praeorbulina glomerosa Zone, sporadic specimens.

Stratigraphic and geographic range: Very common in sediments from the base of the Oligocene up to the top of the lower Miocene. In the middle Miocene, this species is represented by very rare specimens. Cosmopolitan distribution.

\section{Globigerinita stainforthi (Bolli, Loeblich, and Tappan) (Plate 12, Figures 10-11)}

1957. Catapsydrax stainforthi Bolli, Loeblich, and Tappan, p. 37 , pl. 7 , fig. 11

Stratigraphic occurrence: Sporadic specimens of this species were found in Hole 200, Core 10, in the upper part of the Globigerinita stainforthi Zone. Phylogenetically, these appear to be the latest specimens of $G$. stainforthi, differing somewhat in morphology from typical specimens of this species.

Stratigraphic and geographic range: The species appears in deposits of the Globorotalia kugleri Zone, but it is very rare; common in the Globigerinita dissimilis and Globigerinita stainforthi zones of Bolli's scale; disappears at the base of the Globigerinatella insueta Zone. Wide geographic distribution.

\section{Globigerinita incrusta Akers} (Plate 12, Figures 7-8)

1955. Globigerinita incrusta Akers, p. 655 , pl. 65, fig. 2A-D

Stratigraphic occurrence: Hole 200, Cores 3-7, 9, 10, upper part of Globigerinita stainforthi Zone, Praeorbulina glomerosa Zone (lower Miocene)-Sphaeroidinella dehiscens-Globoquadrina altispira Zone (lower Pliocene), sporadic specimens.

Stratigraphic and geographic range: This peculiar species has a very long stratigraphic range which includes the whole of the Miocene, Pliocene, and evidently the Quaternary. 
Globigerinatella insueta Cushman and Stainforthi (Plate 12, Figure 3)

1945. Globigerinatella insueta Cushman and Stainforth, p. 68. Stratigraphic occurrence: Hole 200, Core 9, Praeorbulina glomerosa Zone, rare specimens.

Stratigraphic and geographic range: The species appears in the Globigerinita stainforthi Zone, but it is most common in deposits of the Globigerinatella insueta Zone of Bolli's zonal scheme (Burdigalian Stage). The species is characterized by a wide geographic distribution, but, as a rule, it is found in small numbers of specimens.

\section{Praeorbulina transitoria (Blow)}

(Plate 32, Figures 3-4)

1956. Globigerinoides transitoria Blow, p. 65 , text-fig. 2, Nos. 12-15.

Stratigraphic occurrence: Hole 200, Cores 9, 10, Praeorbulina glomerosa Zone, common; Core 9, Globorotalia peripherorondaOrbulina suturalis Zone, middle Miocene, rare.

Stratigraphic and geographic range: The species is characterized by a short stratigraphic range. The first sporadic specimens of $P$. transitoria appear in the lower part of the Praeorbulina glomerosa Zone; it is found in considerable numbers of specimens somewhat higher in the zone. It disappears in the lowermost part of the Globorotalia peripheroronda-Orbulina suturalis Zone (middle Miocene). Cosmopolitan distribution.

\section{Praeorbulina glomerosa (Blow) (Plate 32, Figures 1-2)}

1956. Globigerinoides glomerosa Blow, p. 64, text-fig. 1, No. 9-19, text-fig. 2, Nos. 1-4.

Stratigraphic occurrence: Hole 200, Cores 9, 10, Praeorbulina glomerosa Zone, comparatively common; Core 9, Globorotalia peripheroronda-Orbulina suturalis Zone (middle Miocene); rare specimens.

Stratigraphic and geographic range: The range of this species is almost the same as that of $P$. transitoria. However, $P$. glomerosa (including all its varieties-curva, glomerosa, circularis) appears somewhat later (middle part of the Praeorbulina glomerosa Zone, lower Miocene) and disappears a little later (middle part of the Globorotalia peripheroronda-Orbulina suturalis Zone, middle Miocene). Cosmopolitan distribution.

\section{Globorotalia obesa Bolli}

1957. Globorotalia obesa Bolli, p. 119, pl. 29, figs. 2-3.

Stratigraphic occurrence: Hole 200, Cores 9 and 10, upper part of Globigerinita stainforthi, Praeorbulina glomerosa (lower Miocene) and Globorotalia peripheroronda-Orbulina suturalis (middle Miocene) zones, common; Cores 6, 7, Globorotalia acostaensisGloborotalia merotumida Zone (Tortonian Stage, upper Miocene), rare specimens.

Stratigraphic and geographic range: This cosmopolitan species has a very long stratigraphic range. Rare specimens are known from deposits of the Aquitanian Stage; rather common in the Burdigalian Stage and middle Miocene; relatively scarce in upper Miocene and Pliocene deposits.

\section{Globorotalia siakensis LeRoy} (Plate 28, Figures 4-6)

1939. Globorotalia siakensis LeRoy, p. 39, pl. 3, figs. 30, 31 .

Stratigraphic occurrence: Hole 200, Cores 9 and 10, upper part of Globigerinita stainforthi and Praeorbulina glomerosa zones (lower Miocene), Globorotalia peripheroronda-Orbulina suturalis Zone (middle Miocene), common.

Stratigraphic and geographic range: This species appears in the upper Oligocene; rather common in sediments of the lower Miocene and the lower part of the middle Miocene; in the top of the middle Miocene it occupies a subordinate position.

Globorotalia continuosa Blow

(Plate 19, Figures 10-12)

1959. Globorotalia continuosa Blow, p. 218, pl. 19, fig. 125.
Stratigraphic occurrence: Hole 200, Core 9, Praeorbulina glomerosa Zone (lower Miocene) and Globorotalia peripheroronda. Orbulina suturalis Zone (middle Miocene), common; Core 7, Globorotalia acostaensis-Globorotalia merotumida Zone (upper Miocene), rare specimens.

Stratigraphic and geographic range: The species is representative of the Burdigalian Stage (lower Miocene), middle Miocene and the lower part of the upper Miocene (Tortonian Stage).

\section{Globorotalia peripheroronda Blow and Banner (Plate 26, Figures 7-9)}

1966. Globorotalia peripheroronda Blow and Banner, p. 294, pl. I, fig. 1, pl. 2, figs. 1-3.

Stratigraphic occurrence: Hole 200, Core 9, Praeorbulina glomerosa Zone, lower Miocene and Globorotalia peripherorondaOrbulina suturalis Zone, middle Miocene, common or relatively rare.

Stratigraphic and geographic range: Rare specimens of $G$. peripheroronda appear in the top of the Aquitanian Stage (Globigerinita stainforthi Zone); the species is common in deposits of the Burdigalian Stage (lower Miocene) and basal layers of the middle Miocene (Globorotalia peripheroronda-Orbulina suturalis Zone); it disappears in the middle part of the middle Miocene. The species has been recorded from the lower-middle Miocene of many countries.

\section{Globorotalia archeomenardii Bolli}

(Plate 18, Figures 7-9)

1957. Globorotalia archeomenardii Bolli, p. 119, pl. 28, fig. 11.

Stratigraphic occurrence: Hole 200, Core 9, Praeorbulina glomerosa Zone, rare specimens.

Stratigraphic and geographic range: The species has been observed in a relatively limited number of regions of the tropical and subtropical areas. According to Bolli (1957), G. archeomenardii is characteristic of the upper part of the Globigerinatella insueta Zone (lower Miocene) and the lower part of the middle Miocene (up to the lower part of the Globorotalia fohsi fohsi Zone).

\section{Middle Miocene}

As shown above, the middle Miocene deposits penetrated by Hole 200 can be attributed to the lowermost part of the middle Miocene (the Globorotalia peripheroronda-Orbulina suturalis Zone). Predominant in the fauna are species Globoquadrina, Globigerina, and Globorotalia. The constant presence of Orbulina suturalis Bronn., Globorotalia praemenardii Cushm. and Stainf., and G. (Clavatorella) bermudezi (Bolli) confirm that these sediments belong to the lowermost part of the middle Miocene.

\section{Orbulina suturalis Bronnimann}

(Plate 31, Figure 10)

1951. Orbulina suturalis Bronnimann, p. 135, text-fig. 2, No. 1-2, $5-8,10$; text-fig. 3 , Nos. $3-8,11,13-16,18,20-22$; text-fig. 4 , Nos. 2-4, 7-12, 15-16, 19-22.

Stratigraphic occurrence: Hole 200, Core 9, Globorotalia peripheroronda-Orbulina suturalis Zone, common.

Stratigraphic and geographic range: The species is very widely distributed in the Miocene of the tropical, subtropical, and temperate areas (it is also known under the name of Candorbulina universa Jedl.). Orbulina suturalis appears in the top of the Praeorbulina glomerosa Zone (lower Miocene, base of Orbulina suturalis Zone) abundant in middle Miocene sediments, and rare in the upper Miocene.

\section{Globorotalia praemenardii Cushman and Stainforth}

1945. Globorotalia praemenardii Cushman and Stainforth, p. 70, pl. 13, fig. 14.

Stratigraphic occurrence: Hole 200, Core 9, Globorotalia peripheroronda-Orbulina suturalis Zone, rare specimens.

Stratigraphic and geographic range: A common species of the middle Miocene (predominantly the lower half) of tropical and subtropical areas. 
Globorotalia (Clavatorella) bermudezi (Bolli)

(Plate 18, Figures 10-12)

1957. Hastigerinella bermudezi Bolli, p. 112, pl. 25, Fig. 1.

Stratigraphic occurrence: Hole 200, Core 9, Globorotalia peripheroronda-Orbulina suturalis Zone, comparatively rare specimens.

Stratigraphic and geographic range: The species is characterized by a short stratigraphic range-the lowermost part of the middle Miocene (Globorotalia peripheroronda-Orbulina suturalis Zone). It occurs predominantly in tropical areas.

\section{Globorotalia peripheroacuta Blow and Banner}

1966. Globorotalia peripheroacuta Blow and Banner, p. 294, pl. 1, fig. 2, pl. 2, figs. 4-5, 13.

Stratigraphic occurrence: Hole 200, Core 9, Globorotalia peripheroronda-Orbulina suturalis Zone, rare specimens. It is likely that the presence of $G$. peripheroacuta in sediments of this zone is related to downhole contamination.

Stratigraphic and geographic range: The middle part of the middle Miocene (Globorotalia peripheroacuta Zone, Globorotalia fohsi Zone of Bolli's zonal scheme), common from the middle Miocene of tropical and subtropical areas.

Late Miocene

\section{Biorbulina bilobata (d’Orbigny)} (Plate 4, Figure 4)

1846. Globigerina bilobata d'Orbigny, p. 164, pl. 9, figs. 11-14.

Stratigraphic occurrence: Hole 200, Cores 1-7, upper Miocene, Pliocene, Quarternary; Hole 200A, Core 1 and Hole 202, Core 1, lower Pliocene; rare and sporadic specimens.

Stratigraphic and geographic range: This cosmopolitan species is frequently observed in the middle Miocene; in sediments of the upper Miocene, Pliocene, and Quaternary, the number of specimens decreases.

\section{Orbulina universa d'Orbigny}

(Plate 31, Figure 11)

1839. Orbulina universa d'Orbigny, p. 2, pl. 1, fig. 1 (in Ellis and Messina).

Stratigraphic occurrence: Hole 200, Cores 1-7, upper Miocene, Pliocene, Quaternary; Hole 200A, Core 1 and Hole 202, Core 1, lower Pliocene; common, sometimes abundant.

Stratigraphic and geographic range: Infrequent numbers of $O$. universa appear in the upper part of the middle Miocene; abundant beginning from the base of the Tortonian Stage (upper Miocene). Cosmopolitan distribution.

\section{Hastigerina siphonifera (d'Orbigny)}

(Plate 31, Figures 7-9)

1839. Globigerina siphonifera d'Orbigny, p. 83 , pl. 4, figs. $15-18$ (in Ellis and Messina).

Stratigraphic occurrence: Hole 200, Cores 1-7, upper Miocene, Pliocene, Quaternary; Hole 200A, Core 1 and Hole 202, Core 1, lower Pliocene; relatively rare or sporadic specimens.

Stratigraphic and geographic range: Sporadic specimens of this species are known from the top of the lower Miocene. However, only beginning with the base of the middle Miocene (the Globorotalia peripheroronda-Orbulina suturalis Zone) does Hastigerina siphonifera become a constant component of planktonic foraminiferal assemblages. It is observed in middle Miocene through Quaternary deposits.

\section{Sphaeroidinellopsis seminulina (Schwager)}

(Plate 34, Figures 6-7)

1866. Globigerina seminulina Schwager (neotype, 1960, Banner and Blow, p. 24, pl. 7, fig. 7).

Stratigraphic occurrence: Hole 200, Core 9, Globorotalia peripheroronda-Orbulina suturalis Zone, middle Miocene, rare; Cores 3-7, upper Miocene, lower Pliocene, common; Hole 200A, Core 1 and Hole 202, Core 1, lower Pliocene (Sphaeroidinella dehiscens-Globoquadrina altispira Zone), common.
Stratigraphic and geographic range: Sporadic specimens of Sph. seminulina appear at the top of the lower Miocene; it can be frequently observed in deposits of the middle and upper Miocene and lower Pliocene. It has a wide geographical distribution, and is most common from sediments of tropical and subtropical areas.

\section{Sphaeroidinellopsis subdehiscens (Blow) \\ (Plate 34, Figures 8-9)}

1959. Sphaerodinella dehiscens subdehiscens Blow, p. 195, pl. 12, fig. 71 .

Stratigraphic occurrence: Hole 200, Cores 3-7, Globorotalia acostaensis-Globorotalia merotumida Zone (upper Miocene), Sphaeroidinella dehiscens-Globoquadrina altispira Zone (lower Pliocene), common; Hole 200A, Core 1 and Hole 202, Core 1, lower Pliocene, common.

Stratigraphic and geographic range: The species appears in the upper part of the middle Miocene (Sphaeroidinellopsis subdehiscens. Globigerina druryi Zone of Blow's zonal scheme). Common in sediments of the upper Miocene and lower Pliocene of tropical and subtropical areas (disappears at the top of the Sphaeroidinella dehiscens-Globoquadrina altispira Zone).

\section{Candeina nitida praenitida Blow}

(Plate 4, Figure 6)

1969. Candeina nitida praenitida Blow, p. 385 , pl. 22 , figs. $5-8$.

Stratigraphic occurrence: Hole 200, Cores 5, 6 and 7, Globorotalia acostaensis-Globorotalia merotumida Zone and Globorotalia tumida plesiotumida Zone, upper Miocene, rare specimens.

Stratigraphic and geographic range: According to Blow (1969), C. nitida praenitida is distinguished from $C$. nitida nitida "in possessing intercameral sutural apertures confined to the last two chambers only of the final whorl" and is characterized by a short stratigraphic range-the same two zones of the upper Miocene as in the Miocene of the Caroline Abyssal Plain.

Pulleniatina primalis Banner and Blow (Plate 32, Figures 8-10)

1967. Pulleniatina primalis Banner and Blow, p. 142, pl. 1, figs. 3-8, pl. 3 , fig. 2.

Stratigraphic occurrence: Hole 200, Cores 4 and 5, Globorotalia tumida plesiotumida and Globorotalia tumida tumida-Sphaeroidinellopsis subdehiscens paenedehiscens Zones (upper Miocene, Messinian Stage), sporadic specimens, but sometimes common.

Stratigraphic and geographic range: The species appears in the upper Miocene (Globorotalia tumida plesiotumida Zone) and disappears in the lower Pliocene (likely in the top of the Sphaeroidinella dehiscens-Globoquadrina altispira Zone). It is frequently observed in deposits of the upper Miocene (Messinian Stage) and lower Pliocene of tropical and subtropical areas.

\section{Globigerinita naparimaensis Bronnimann}

(Plate 12, Figure 9)

1951. Globigerinita naparimaensis Bronnimann, p. 18.

Stratigraphic occurrence: Hole 200, Cores 6 and 7, Globorotalia acostaensis-Globorotalia merotumida Zone (Tortonian Stage, upper Miocene), sporadic specimens.

Stratigraphic and geographic range: Relatively rare in deposits of the upper part of the middle Miocene and the lower part of the upper Miocene (Tortonian Stage) of tropical and subtropical areas.

\section{Globigerinita glutinata (Egger)}

(Plate 12, Figure 6)

1895. Globigerina glutinata Egger, p. 371, pl. 13, figs. 19-21 (in Ellis and Messina).

Stratigraphic occurrence: Hole 200, Cores 1-7, upper Miocene (Globorotalia acostaensis-Globorotalia merotumida Zone), Quaternary; Hole 200A, Core 1 and Hole 202, Core 1, lower Pliocene; rare specimens, sometimes common.

Stratigraphic and geographic range: This species seems to appear in the middle Miocene; common in upper Miocene through Quaternary deposits of tropical, subtropical and temperate areas. 
Globorotaloides variabilis Bolli

1957. Globorotaloides variabilis Bolli, p. 117, pl. 27, figs. 15-20. Stratigraphic occurrence: Hole 200, Cores 6 and 7, upper Miocene (Globorotalia acostaensis-Globorotalia merotumida Zone), comparatively rare specimens.

Stratigraphic and geographic range: The species is found in deposits of the middle Miocene and the lower part of the upper Miocene (Tortonian Stage) of tropical and subtropical areas.

\section{Globigerina nepenthes Todd}

(Plate 9, Figures 4-6)

1957. Globigerina nepenthes Todd, p. 301, pl. 78, fig. 7.

Stratigraphic occurrence: Hole 200, Cores 3-7, upper Miocene (Tortonian Stage, Globorotalia acostaensis-Globorotalia merotumida Zone), lower Pliocene (Sphaeroidinella dehiscens-Globoquadrina altispira Zone); Hole 200A, Core 1 and Hole 202, Core 1, lower Pliocene; abundant or common.

Stratigraphic and geographic range: This biostratigraphically important species appears in the uppermost part of the middle Miocene; widely developed in sediments of the upper Miocene (Tortonian and Messian stages) and lower Pliocene (Sphaeroidinella dehiscens-Globoquadrina altispira Zone). Wide geographical distribution.

\section{Globigerina bulloides d'Orbigny}

1826. Globigerina bulloides d'Orbigny, p. 277 (in Ellis and Messina). Stratigraphic occurrence: Hole 200, Cores 1-7, upper Miocene (Tortonian Stage, Globorotalia acostaensis-Globorotalia merotumida Zone), Quaternary; Hole 200A, Core 1 and Hole 202, Core 1, lower Pliocene; very common.

Stratigraphic and geographic range: This widespread species (from tropical to boreal regions) is frequently observed in sediments of the upper Miocene, Pliocene, and Quaternary.

\section{Globigerina bulbosa LeRoy} (Plate 6, Figures 9-11)

1944. Globigerina bulbosa LeRoy, p. 39, pl. 3, figs. 26-27.

Stratigraphic occurrence: Hole 200, Cores 6 and 7 , upper Miocene (Tortonian Stage, Globorotalia acostaensis-Globorotalia merotumida Zone), comparatively rare.

Stratigraphic and geographic range: $G$. bulbosa appears in the upper part of the middle Miocene, but is most characteristic of the lower part of the upper Miocene (Tortonian Stage). The last specimens of $G$. bulbosa seem to disappear in the Messinian Stage; wide geographic range.

\section{Globigerina parabulloides Blow \\ (Plate 9, Figures 7-9)}

1959. Globigerina parabulloides Blow, p. 179, pl. 10, fig. 46 .

Stratigraphic occurrence: Hole 200, Cores $3,4,5,6$, upper Miocene (Globorotalia acostaensis-Globorotalia merotumida Zone), lower Pliocene (Sphaeroidinella dehiscens-Globoquadrina altispira Zone); Hole 202, Core 1, lower Pliocene; sporadic specimens.

Stratigraphic and geographic range: The species appears in deposits of the upper part of the middle Miocene (Sphaeroidinellopsis subdehiscens-Globigerina druryi Zone of Blow); common in the upper Miocene, Pliocene, and Quaternary deposits of tropical, subtropical, and temperate regions.

\section{Globigerina decoraperta Takayanagi and Saito} (Plate 7, Figures 1-2)

1962. Globigerina druryi decoraperta Takayanagi and Saito, p. 85, pl. 28, fig. 10 .

Stratigraphic occurrence: Hole 200, Cores 4, 5, 6, upper Miocene (from the Globorotalia acostaensis-Globorotalia merotumida Zone up to the Globorotalia tumida tumida-Sphaeroidinellopsis subdehiscens paenedehiscens Zone), comparatively rare specimens.

Stratigraphic and geographic range: $G$. decoraperta has been recorded in sediments of the uppermost part of the middle Miocene (the Globigerina nepenthes-Globorotalia siakensis Zone of Blow), but is most characteristic of the upper Miocene. The species is also found in the Pliocene.

\section{Globigerina eamesi Blow \\ (Plate 7, Figures 3-5)}

1959. Globigerina eamesi Blow, p. 176, pl. 9, fig. 39 .

Stratigraphic occurrence: Hole 200, Cores 5, 6, upper Miocene (Globorotalia acostaensis-Globorotalia merotumida and Globorotalia tumida plesiotumida zones), sporadic specimens.

Stratigraphic and geographic range: According to Blow (1969), the stratigraphic interval of $G$. eamesi covers the latest part of the middle Miocene (Globigerina nepenthes-Globorotalia siakensis zone) and the whole upper Miocene.

\section{Globigerina microstoma Cita, Premoli Silva and Rossi} (Plate 8, Figures 7-8)

1965. Globigerina microstoma Cita, Premoli Silva and Rossi, p. 250, pl. 25 , figs. $1-2$, pl. 31 , fig. 1 .

Stratigraphic occurrence: Hole 200, Cores 5 and 6, upper Miocene (Tortonian and Messinian stages, Globorotalia acostaensisGloborotalia merotumida and Globorotalia tumida plesiotumida zones), sporadic specimens.

Stratigraphic and geographic range: Upper Miocene of tropical and subtropical areas.

\section{Globigerinoides adriatica (Fornasini) \\ (Plate 13, Figures 1-2)}

1899. Globigerina adriatica Fornasini, p. 10, pl. 3, figs, 6, 7 (in Ellis and Messina).

Stratigraphic occurrence: Hole 200, Cores 5 and 6, upper Miocene (Tortonian and Messinian stages, Globorotalia acostaensis Globorotalia merotumida and Globorotalia tumida plesiotumida zones), sporadic specimens.

Stratigraphic and geographic range: As the species was originally described from Quaternary deposits of the Mediterranean, the stratigraphic interval of $G$. adriatica includes the upper Miocene, Pliocene, and Quaternary.

\section{Globigerinoides parkerae Bermudez}

1961. Globigerinoides parkerae Bermudez, p. 232 , pl. 10 , figs. 10 , 11.

Stratigraphic occurrence: Hole 200, Cores 4, 5, 6, upper Miocene (Globorotalia acostaensis-Globorotalia merotumida, Globorotalia tumida plesiotumida, and Globorotalia tumida tumida-Sphaeroidinellopsis subdehiscens paenedehiscens zones), relatively rare specimens; Hole 200A, Core 1, lower Pliocene, rare specimens.

Stratigraphic and geographic range: $G$. parkerae evidently appears at the very top of the middle Miocene, common in sediments of the upper Miocene and Pliocene of tropical and subtropical areas.

\section{Globigerinoides obliquus obliquus Bolli (Plate 14, Figures 5-6)}

1957. Globigerinoides obliqua Bolli, p. 113, pl. 25, figs. 9-10.

Stratigraphic occurrence: Hole 200, Cores 3-7, upper Miocene (Globorotalia acostaensis-Globorotalia merotumida, Globorotalia tumida plesiotumida, Globorotalia tumida tumida-Sphaeroidinellopsis subdehiscens paenedehiscens zones) and lower Pliocene (Sphaeroidinella dehiscens-Globoquadrina altispira Zone), common; Hole 202, Core 1, lower Pliocene, comparatively rare specimens.

Stratigraphic and geographic range: $G$. obliquus obliquus has a very long stratigraphic range (lower Miocene through Quaternary). This subspecies is rather abundant in the upper part of the middle Miocene and most characteristic of the upper Miocene and the lower half of the Pliocene. Wide geographic distribution.

\section{Globigerinoides obliquus extremus Bolli and Bermudez} (Plate 14, Figures 3-4)

1965. Globigerinoides obliquus extremus Bolli and Bermudez, p. 159 , pl. 1 , figs. $10-12$. 
Stratigraphic occurrence: Hole 200, Cores $3,4,5,6$, the same stratigraphic distribution as $G$. obliquus obliquus (upper Miocenelower Pliocene). However, in the Globorotalia acostaensisGloborotalia merotumida Zone this subspecies is uncommon, becoming common in the Globorotalia tumida plesiotumida Zone (Messinian Stage).

Stratigraphic and geographic range: upper Miocene-Pliocene.

\section{Globigerinoides bollii Blow}

(Plate 13, Figures 3-4)

1959. Globigerinoides bollii Blow, p. 189, pl. 10, fig. 65 .

Stratigraphic occurrence: Hole 200, Cores 3-7, upper Miocene (Globorotalia acostaensis-Globorotalia merotumida, Globorotalia tumida plesiotumida, and Globorotalia tumida tumida-Sphaeroidinellopsis subdehiscens paenedehiscens Zones) and lower Pliocene (Sphaeroidinella dehiscens-Globoquadrina altispira zone); common, sometimes rare; Hole 202, Core 1, lower Pliocene, rare specimens.

Stratigraphic and geographic range: $G$. bollii appears in the upper part of the middle Miocene; most frequently, however, it is observed in the upper Miocene and lower Pliocene. It probably disappears in the upper part of the Pliocene.

\section{Globigerinoides conglobatus canimarensis Bermudez} (Plate 13, Figures 7-8)

1961. Globigerinoides canimarensis Bermudez, p. 225, pl. 10, fig. 5 . Stratigraphic occurrence: Hole 200, Cores 5 and 6 , upper Miocene (Globorotalia acostaensis-Globorotalia merotumida and Globorotalia tumida plesiotumida zones), rare specimens.

Stratigraphic and geographic range: Upper Miocene of tropical regions.

\section{Globorotalia merotumida Blow and Banner}

(Plate 25, Figures 1-3)

1965. Globorotalia merotumida Blow and Banner, in Banner and Blow, 1965, p. 1352, fig. 1.

Stratigraphic occurrence: Hole 200, Core 7, upper Miocene (Globorotalia acostaensis-Globorotalia merotumida Zone), rare specimens; Core 6, upper Micoene (the same zone), common; Core 5, upper Miocene (Globorotalia tumida plesiotumida Zone), rare specimens.

Stratigraphic and geographic range: Upper Miocene (within the Globorotalia acostaensis-Globorotalia merotumida Zone and the Globorotalia tumida tumida-Sphaeroidinellopsis subdehiscens paenedehiscens Zone).

\section{Globorotalia paralenguaensis Blow}

1969. Globorotalia paralenguaensis Blow, p. 402 , pl. 46, figs. 1-6.

Stratigraphic occurrence: Hole 200, Core 6, upper Miocene, Globorotalia acostaensis-Globorotalia merotumida Zone, rare specimens.

Stratigraphic and geographic range: According to Blow (1969), who described this species from the upper Miocene of Papua, $G$. paralenguaensis is characterized by a short stratigraphic range: the upper part of the Globorotalia continuosa Zone through the lower part of the Globorotalia acostaensis-Globorotalia merotumida Zone.

Globorotalia pseudopachyderma Cita, Premoli Silva, and Rossi (Plate 27, Figures 4-6)

1965. Globorotalia pseudopachyderma Cita, Premoli Silva, and Rossi, p. 233, pl. 20, figs. $3,4,6$; pl. 31, fig. 6 ; text-fig. 5 .

Stratigraphic occurrence: Hole 200, Core 6, upper Miocene, Globorotalia acostaensis-Globorotalia merotumida Zone, rare specimens.

Stratigraphic and geographical range: This species has been found in the upper Miocene (Tortonian and Messinian stages) of the Mediterranean, and in the Atlantic and Pacific oceans.

\section{Globorotalia acostaensis Blow}

(Plate 17, Figures 4-6)

1959. Globorotalia acostaensis Blow, p. 208, pl. 17, figs. 106-107.

Stratigraphic occurrence: Hole 200, Cores 6 and 7 , upper Miocene, Globorotalia acostaensis-Globorotalia merotumida Zone, rare specimens; Cores 3-5, upper Miocene (Globorotalia tumida plesiotumida Zone) through lower Pliocene (Sphaeroidinella dehiscens-Globoquadrina altispira Zone), very rare specimens. Hole 202, Core 1, Pliocene, very rare specimens.

Stratigraphic and geographic range: The species has a rather long stratigraphic range-upper Miocene and Pliocene. However, $G$. acostaensis is most frequently observed in upper Miocene deposits (Globorotalia acostaensis-Globorotalia merotumida and Globorotalia tumida plesiotumida zones). Cosmopolitan species.

\section{Globorotalia menardii (d'Orbigny)}

(Plate 24, Figures 11-13)

1826. Rotalia menardii d'Orbigny, p. 273 , mod. N 10 (in Ellis and Messina).

Stratigraphic occurrence: Hole 200, Cores 1-7, upper Miocene (Globorotalia acostaensis-Globorotalia merotumida Zone) through Quaternary; frequent or common in the upper Miocene, common or rare in Pliocene and Quaternary sediments. Hole 200A, Core 1 and Hole 202, Core 1, lower Pliocene, common.

Stratigraphic and geographic range: The species is common in deposits of the uppermost part of the middle Miocene (?), upper Miocene, Pliocene and Quaternary of tropical and subtropical areas.

\section{Globorotalia cultrata (d'Orbigny)}

(Plate 20, Figures 4-6)

1839. Rotalina cultrata d'Orbigny, p. 76, pl. 5, figs. 7-9 (in Ellis and Messina).

Stratigraphic occurrence: The same as Globorotalia menardii. Hole 200, Core 7-1, upper Miocene through Quaternary; Hole 200A, Core 1, lower Pliocene; Hole 202, Core 1, Pliocene.

Stratigraphic and geographic range: The same as Globorotalia menardii. Upper Miocene through Quaternary of tropical and subtropical regions.

\section{Globorotalia tumida plesiotumida Blow and Banner} (Plate 00, Figures 10-12)

1965. Globorotalia tumida plesiotumida Blow and Banner, in Banner and Blow, 1965, p. 1353, fig. 2.

Stratigraphic occurrence: Hole 200, Core 5, upper Miocene, Globorotalia tumida plesiotumida Zone, abundant or common; Core 4, upper Miocene, Globorotalia tumida tumida-Sphaeroidinellopsis subdehiscens paenedehiscens Zone, sporadic specimens.

Stratigraphic and geographic range: The stratigraphic interval of the species in Hole 200 corresponds to its whole interval (upper Miocene, Messinian Stage). Globorotalia tumida plesiotumida is common in Messinian deposits of tropical and subtropical areas.

\section{Globorotalia multicamerata Cushman and Jarvis} (Plate 25, Figures 7-9)

1930. Globorotalia multicamerata Cushman and Jarvis, p. 367 , pl. 34 , fig. 8.

Stratigraphic occurrence: Hole 200, Cores 4 and 5, upper Miocene (Globorotalia tumida plesiotumida Zone and Globorotalia tumida tumida-Sphaeroidinellopsis subdehiscens paenedehiscens Zone), common; Core 3, lower Pliocene (Sphaeroidinella dehiscensGloboquadrina altispira Zone), common; Core 2, upper Pliocene (basal layers of the Globorotalia tosaensis Zone), rare specimens. Hole 200A, Core 1 and Hole 202, Core 1, lower Pliocene, common or rare specimens.

Stratigraphic and geographic range: The stratigraphic interval of the species covers the upper Miocene (Globorotalia tumida plesiotumida Zone) and the middle part of the Pliocene (Globorotalia multicamerata-Pulleniatina obliquiloculata Zone). The last scarce specimens of $G$. multicamerata are observed at the base of the upper Pliocene.

\section{Globorotalia miocenica Palmer}

(Plate 25, Figures 4-6)

1945. Globorotalia menardii miocenica Palmer, p. 70, pl. 1, fig. 10.

Stratigraphic occurrence: Hole 200, Cores 4 and 5, upper Miocene (Globorotalia tumida plesiotumida Zone and Globorotalia tumida tumida-Sphaeroidinellopsis subdehiscens paenedehiscens Zone), common, sometimes rare. 
Stratigraphic and geographic range: Reports of Tortonian specimens of $G$. miocenica are likely to be erroneous. The species is representative of the Messinian Stage of the upper Miocene and the lower part of the Pliocene. G. miocenica disappears at the lower boundary of the upper Pliocene (Globorotalia tosaensis Zone). Common in the upper Miocene-lower Pliocene of tropical and subtropical areas.

\section{Globorotalia margaritae Bolli and Bermudez \\ (Plate 24, Figures 1-4)}

1965. Globorotalia margaritae Bolli and Bermudez, p. 139, pl. 1, figs. 16-18.

Stratigraphic occurrence: Hole 200, Core 6, upper Miocene (Globorotalia acostaensis-Globorotalia merotumida Zone), sporadic specimens (their presence may be related to downhole contamination); Cores 4 and 5, upper Miocene (Globorotalia tumida plesiotumida Zone and Globorotalia tumida tumida-Sphaeroidinellopsis subdehiscens paenedehiscens Zone), common, sometimes rare; Core 3, lower Pliocene (Sphaeroidinella dehiscens-Globoquadrina altispira Zone), common. Hole 200A, Core 1 and Hole 202, Core 1, lower Pliocene, common or rare.

Stratigraphic and geographic range: Questionable specimens of G. margaritae have been recognized in deposits of the Globorotalia acostaensis-Globorotalia merotumida Zone (upper Miocene, Tortonian Stage). The species is representative of sediments of the upper part of the Globorotalia tumida plesiotumida Zone (upper Miocene, Messinian Stage) and the Sphaeroidinella dehiscens-Globoquadrina altispira Zone (lower Pliocene). It has been recorded in countries of the Caribbean area, the Mediterranean, and the Atlantic and Pacific oceans.

\section{Pliocene-Quaternary}

\section{Pulleniatina obliquiloculata (Parker and Jones)}

(Plate 32, Figures 5-7)

1862. Pullenia obliquiloculata Parker and Jones (in Banner and Blow, 1967, p. 137, pl. 3, fig. 4, pl. 4, fig. 9)

Stratigraphic occurrence: Hole 200, Cores 1-3, PlioceneQuaternary, frequent or common; Hole 200A, Core 1 and Hole 202, Core 1, Pliocene (Sphaeroidinella dehiscens-Globoquadrina altispira Zone), common.

Stratigraphic and geographic range: Cosmopolitan species in Pliocene and Quaternary deposits.

\section{Pulleniatina aff. spectabilis Parker (Plate 33, Figures 1-3)}

Stratigraphic occurrence: Numerous specimens of this species, similar to $P$. spectabilis Parker in their morphology $(1965$, p. 151 , text-figs. 1-4), were found in the lower Pliocene (Sphaeroidinella dehiscens-Globorotalia altispira Zone) of Hole 200, Core 3.

\section{Sphaeroidinella dehiscens (Parker and Jones)}

(Plate 34, Figures 1-2)

1865. Sphaeroidina dehiscens Parker and Jones (in Banner and Blow, 1960, p. 35, pl. 7, fig. 3).

Stratigraphic occurrence: Hole 200, Cores 1-3, PlioceneQuaternary, frequent; Hole 200A, Core 1 and Hole 202, Core 1, lower Pliocene (Sphaeroidinella dehiscens-Globoquadrina altispira Zone), common.

Stratigraphic and geographic range: Cosmopolitan species in Pliocene and Quaternary deposits.

\section{Candeina nitida d'Orbigny}

1839. Candeina nitida d'Orbigny, p. 107 (in Bolli, Loeblich and Tappan, p. 35, pl. 6, figs. 10-11).

Stratigraphic occurrence: Hole 200, Core 6, upper Miocene (Globorotalia acostaensis-Globorotalia merotumida Zone), sporadic specimens (downhole contamination is not excluded); Cores 4 and 5 , upper Miocene (Globorotalia tumida plesiotumida Zone and the Globorotalia tumida tumida-Sphaeroidinellopsis subdehiscens paenedehiscens Zone), rare specimens; Cores 1-3, Pliocene-
Quaternary, common or rare specimens. Hole 200A, Core 1 and Hole 202, Core 1, lower Pliocene, common or rare specimens.

Stratigraphic and geographic range: This species appears in the upper Miocene (Globorotalia tumida plesiotumida Zone), but it is most characteristic of Pliocene and Quaternary deposits of the tropical and subtropical areas.

\section{Globigerinoides conglobatus (Brady)}

(Plate 13, Figures 5-6)

1884. Globigerina conglobata Brady, p. 603 , pl. 80 , figs. 1-5, pl. 82, fig. 5 .

Stratigraphic occurrence: Hole 200, Cores 1-3, lower PlioceneQuaternary, frequent or common; Hole 200A, Core 1 and Hole 202, Core 1 , lower Pliocene, frequent or common.

Stratigraphic and geographic range: This cosmopolitan species can frequently be observed in Pliocene and Quaternary deposits. According to Blow (1969), G. conglobatus appears in the upper Miocene (Globorotalia tumida plesiotumida Zone).

\section{Globigerinoides sacculifer (Brady)}

(Plate 14, Figures 10-12)

1884. Globigerina sacculifera Brady, p. 604 , pl. 80 , figs. $11-17$, pl. 82 , fig. 4 .

Stratigraphic occurrence: Hole 200, Cores 1-3, lower PlioceneQuaternary, common; Hole 200A, Core 1 and Hole 202, Core 1, lower Pliocene, common.

Stratigraphic and geographic range: This cosmopolitan species is characteristic of Pliocene and Quaternary deposits. However, it has a highly variable morphology; there are different opinions concerning the scope of $G$. sacculifer and, hence, its stratigraphic range. Thus, as Blow believes (1969), the stratigraphic interval of $G$. sacculifer includes the lower Miocene (Globigerinita stainforthi Zone) through Quaternary.

\section{Globigerinoides fistulosus (Schubert)} (Plate 13, Figures 10-12)

1910. Globigerina fistulosa Schubert, p. 323, pl. 2, fig. 13.

Stratigraphic occurrence: Hole 200, Core 2, upper Pliocene (Globorotalia tosaensis Zone), common.

Stratigraphic and geographic range: This species appears at the top of the upper Miocene (Globorotalia tumida tumida-Sphaeroidinellopsis subdehiscens paenedehiscens Zone) and is developed in Pliocene deposits (predominantly in tropical areas). It does not range above the Pliocene-Quaternary boundary.

\section{Globorotalia humerosa Takayanagi and Saito} (Plate 22, Figures 7-9)

1962. Globorotalia humerosa Takayanagi and Saito, p. 78, pl. 28, figs. 1-2.

Stratigraphic occurrence: Hole 200, Core 4, upper Miocene (Globorotalia tumida tumida-Sphaeroidinellopsis subdehiscens paenedehiscens Zone), comparatively rare specimens; Cores 1-3, Pliocene-Quaternary, frequent or common. Hole 200A, Core 1 and Hole 202, Core 1, lower Pliocene, common.

Stratigraphic and geographic range: $G$. humerosa is found in deposits of the upper Miocene (Globorotalia tumida plesiotumida Zone and Globorotalia tumida tumida-Sphaeroidinellopsis subde. hiscens paenedehiscens Zone), Pliocene and Quaternary of many regions of the Caribbean, Mediterranean, and the Atlantic and Pacific Oceans.

\section{Globorotalia inflata (d'Orbigny)}

(Plate 23, Figures 1-3)

1839. Globigerina inflata d'Orbigny, p. 134, pl. 2, figs. 7-9 (see Banner and Blow, 1967, p. 145, pl. 4, figs. 1, 11).

Stratigraphic occurrence: Hole 200, Cores 1-3, PlioceneQuaternary, comparatively rare; Hole 200A, Core 1 and Hole 202, Core 1 , lower Pliocene, comparatively rare.

Stratigraphic and geographic range: $G$. inflata appears at the top of the upper Miocene, and is representative of Pliocene and Quaternary deposits. The species is characteristic of temperate and subtropical areas; it is rare in tropical areas. 


\section{Globorotalia ungulata Bermudez}

(Plate 30, Figures 1-3)

1960. Globorotalia ungulata Bermudez, p. 304, pl. 15, fig. 6 .

Stratigraphic occurrence: Hole 200, Cores 1-3, PlioceneQuaternary, rare specimens; Hole 202, Core 1, lower Pliocene, rare specimens.

Stratigraphic and geographic range: Pliocene and Quaternary sediments of tropical and subtropical regions.

\section{Globorotalia hirsuta (d'Orbigny)}

(Plate 22, Figures 1-3)

1839. Rotalina hirsuta d'Orbigny (in Blow, 1969, p. 398, pl. 8, figs. $1-3$, pl. 43 , figs. 1,2 ).

Stratigraphic occurrence: Hole 200, Cores 1-3, PlioceneQuaternary, rare; Hole 200A, Core 1, lower Pliocene, rare.

Stratigraphic and geographic range: This species (in a broad sense) is characteristic of Pliocene and Quaternary deposits. Blow (1969) believes that $G$. hirsuta praehirsuta developed in the Pliocene, whereas $G$. hirsuta hirsuta proper appears in Quaternary deposits.

\section{Globorotalia scitula (Brady)}

(Plate 28, Figures 1-3)

1882 Pulvinulina scitula Brady (fide Ellis and Messina, 1940, et seq.) Stratigraphic occurrence: Hole 200, Cores 1-7 (upper Miocene to Quaternary) rare.

Stratigraphic and geographic range: This species appears in the middle Miocene and is common in Pliocene and Quaternary deposits.

\section{Globorotalia crassaformis crassaformis (Galloway and Wissler)} (Plate 20, Figures 1-3)

1927 Globigerina crassaformis Galloway and Wissler, p. 41, pl. 7, fig. 12.

Stratigraphic occurrence: Hole 200, Cores 1-3, PlioceneQuaternary, common; Hole 200A, Core 1 and Hole 202, Core 1, Pliocene, common. Sporadic specimens of G. crassaformis crassaformis have also been recognized at the top of the upper Miocene (Globorotalia tumida tumida-Sphaeroidinellopsis subdehiscens paenedehiscens Zone). However, they can be related to downhole contamination (Hole 200, Core 4).

Stratigraphic and geographic range: $G$. crassaformis crassaformis is widely developed in Pliocene and Quaternary deposits of tropical and especially subtropical and temperate areas. According to Blow (1969), the species appears in the upper Miocene (Globorotalia acostaensis-Globorotalia merotumida Zone).

\section{Globorotalia crassaformis ronda Blow}

1969. Globorotalia crassaformis ronda Blow, p. 388 , pl. 4, figs. 4-6, pl. 37 , figs. 6-9.

Stratigraphic occurrence: Hole 200, Cores 1-3, PlioceneQuaternary, common or rare specimens; Hole 200A, Core 1 and Hole 202, Core 1 , lower Pliocene, relatively rare specimens.

Stratigraphic and geographic range: According to Blow (1969), $G$. crassaformis ronda occurs in sediments of the upper Miocene (Globorotalia tumida plesiotumida Zone) through Quaternary.

\section{Globorotalia tosaensis Takayanagi and Saito}

$$
\text { (Plate 29, Figures 1-3) }
$$

1962. Globorotalia tosaensis Takayanagi and Saito, p. 81 , pl. 28 , figs. 11-12.

Stratigraphic occurrence: Hole 200, Core 2, upper Pliocene (Globorotalia tosaensis Zone), relatively rare specimens.

Stratigraphic and geographic range: This cosmopolitan species is characteristic of the upper part of the Pliocene (Globorotalia tosaensis Zone).

\section{Globorotalia truncatulinoides (d'Orbigny)}

1839. ?Rotalina truncatulinoides d'Orbigny (neotype, Blow, 1969 , p. 403 , pl. 5 , figs. $10-12$, pl. 49 , fig. 6 ).

Stratigraphic occurrence: Hole 200, Core 1, Quaternary (Globorotalia truncatulinoides Zone), common.
Stratigraphic and geographic range: Quaternary deposits. Most characteristic of the sediments of subtropical and temperate areas; less frequent in tropical areas.

\section{ACKNOWLEDGMENTS}

We wish to acknowledge the Deep Sea Drilling Project for providing the opportunity to participate on Leg 20 of the Glomar Challenger, and the New Zealand Geological Survey, Department of Scientific and Industrial Research, and the Geological Institute of the Academy of Sciences of the USSR for leave.

We wish to acknowledge the Physics and Engineering Laboratory, Department of Scientific and Industrial Research, Lower Hutt for the use of their Scanning Electron Microscope; B. J. Burt, New Zealand Geological Survey, who operated the Scanning Electron Microscope; and the Photographic Section, New Zealand Geological Survey, for the photography.

\section{REFERENCES}

Akers, W. H., 1955. Some planktonic foraminifera of the American Gulf Coast and suggested correlations with the Caribbean Tertiary: J. Paleont., v. 29, p. 647-664.

Banner, F. T. and Blow, W. H., 1965. Two new taxa of the Globorotaliinae (Globigerinacea, Foraminifera) assisting determination of the Late Miocene/Middle Miocene boundary: Nature, v. 207, no. 5004, p. 1351-1354. 1967. The origin, evolution, and taxonomy of the foraminiferal genus Pulleniatina Cushman, 1927: Micropaleontology, v. 13, no. 2, p. 133-162.

Beckmann, J. P., 1957. Chiloguembelina Loeblich and Tappan and related foraminifera from the lower Tertiary of Trinidad: U. S. Natl. Mus. Bull. 215, p. 83-95.

Bermudez, P. J., 1961. Contribucion al Estudio de las Globigerinidea de la Region Caribe-Antillana. 3rd Congress Geol. Venezolano, Bol. Geol., Mem., v. 3, p. 1.119-1.393.

Blow, W. H., 1956. Origin and evolution of the foraminiferal genus Orbulina, d'Orbigny: Micropaleontology, v. 2, no. 1 , p. 57-70.

1959. Age, correlation, and biostratigraphy of the upper Tocuyo (San Lorenzo) and Pozón formations, eastern Falcón, Venezuela: Bull. Am. Paleont., v. 39, no. 178 , p. $67-251$.

1969. Late middle Eocene to Recent planktonic foraminiferal biostratigraphy: Internatl. Conf. Plankt. Microfossils, 1st, Leiden, Proc. (E. J. Brill), v. 1, p. $199-421$.

1971. Deep Sea Drilling Project, Leg 6, foraminifera from selected samples. In Fischer, A. G., Heezen, B. C., et al., Initial Reports of the Deep Sea Drilling Project, Volume VI: Washington (U. S. Government Printing Office).

Blow, W. H. and Banner, F. T., 1962. The mid-Tertiary (Upper Eocene to Aquitanian) Globigerinaceae. In Eames, F. E., et al., Fundamentals of mid-Tertiary stratigraphical correlation: Cambridge England (Cambridge University Press), p. 61-151.

1966. The morphology, taxonomy and biostratigraphy of Globorotalia barisanensis Le Roy, Globorotalia fohsi Cushman and Ellisor, and related taxa: Micropaleontology, v. 12 , no. 3 , p. 286-302.

Bolli, H. M., 1957. The genera Globigerina and Globorotalia in the Paleocene-Lower Eocene Lizard Springs Formation of Trinidad, B. W. I.: U. S. Natl. Mus. Bull. 215, p. 61-81. 
1957. Planktonic foraminifera from the Oligocene-Miocene Cipero and Lengua formations of Trinidad, B. W. I.: U. S. Natl. Mus. Bull. 215, p. 97-123. 1957. Planktonic foraminifera from the Eocene Navet and San Fernando formations of Trinidad, B. W. I.: U. S. Natl. Mus. Bull. 215, 155.

Bolli, H. M. and Bermudez, P. J., 1965. Zonation based on planktonic foraminifera of middle Miocene to Pliocene warm-water sediments: Asoc. Venezolana Geol. Miner., y Petr., Bol. Informativo, v. 8, no. 5, p. 121-149.

Bolli, H. M., Loeblich, A. R., Jr., and Tappan, H., 1957. Planktonic foraminiferal families Hantkeninidae, Orbulinidae, Globorotaliidae, and Globotruncanidae: U. S. Natl. Mus. Bull. 215, p. 3-50.

Brady, H. B., 1882. Report on the foraminifera. In Tizard and Murray, Exploration of the Faröe Channel, during the summer of 1880 , in H.M.S. Knight Errant, with subsidiary reports: Roy. Soc. Edinburgh, Proc., Edinburgh, v. $11,(1880-1882)$, no. 111, p. $708-717$.

1884. Report on the foraminifera dredged by H.M.S. Challenger during the years 1873-1876: Challenger Exped. 1873-1876, Rept., London, Zool., v. 9, pt. 22, p. 1-814.

Bronnimann, P., 1951. Globigerinita naparimaensis, n. gen., n. sp., from the Miocene of Trinidad, B. W. I.: Contrib. Cushman Found. Foram. Res., v. 2, pt. 1, p. 16-18. , 1951. The genus Orbulina d'Orbigny in the Oligo-Miocene of Trinidad, B. W. I.: Contrib. Cushman Found. Foram. Res., v. 2, pt. 4, p. 132-138.

1952. Trinidad Paleocene and lower Eocene Globigerinidae: Bull. Am. Paleont., v. 34, no. 143, p. 1-34. 1952. Globigerinoita and Globigerinatheka, new genera from the Tertiary of Trinidad: Contrib. Cushman Found. Foram. Res., v. 3, pt. 1, p. 25-28. 1954. In an appendix to Todd, R., Cloud, P. E., Low, D., and Schmidt, R. G., Probable occurrence of Oligocene on Saipan: Am. J. Sci., v. 252, no. 11, p. 673-682.

Bronnimann, P. and Bermudez, P. J., 1953. Truncorotaloides, a new foraminiferal genus from the Eocene of Trinidad, B. W. I.: J. Paleont., v. 27, p. 817-820.

Chapman, F., Parr, W. J., and Collins, A. C., 1934. Tertiary foraminifera of Victoria, Australia - the Balcombian deposits of Port Phillip, Part III: Linnean Soc. J., v. 38, no. 262 , p. $553-577$.

Cita, M. B. and Gelati, R., 1960. Globoquadrina langhiana n. sp. del Langhiano-tipo: Riv. Ital. Paleont., v. 66, no. 2, p. 241-246.

Cita, M. B. and Premoli Silva, I., 1960. Globigerina bollii, nuova specie delle Langhe: Riv. Ital. Paleont., v. 66, no. 1, p. 119-126.

Cita, M. B., Premoli Silva, I,, and Rossi, R., 1965. Foraminiferi plactonici del Tortoniano tipo: Riv. Ital. Paleont., v. 71 , no. 1 , p. $217-308$.

Cushman, J. A., 1924. A new genus of Eocene foraminifera: U. S. Natl. Mus. Proc., v. 66, art. 30, p. 1-4.

1925. Some new foraminifera from the Velasco shale of Mexico: Contrib. Cushman Lab. Foram. Res., v. 1., p. 19.

1927. New and interesting foraminifera from Mexico and Texas: Contrib. Cushman Lab. Foram. Res., v. 3 , p. 114 .

Cushman, J. A. and Bermudez, P. J., 1937. Further new species of foraminifera from the Eocene of Cuba: Contrib. Cushman Lab. Foram. Res., v. 13, pt. 1, p. 1-29. 1949. Some Cuban species of Globorotalia: Contrib. Cushman Lab. Foram. Res., v. 25, pt. 2, p. 26-45.
Cushman, J. A. and Jarvis, P. W., 1929. New foraminifera from Trinidad: Contrib. Cushman Lab. Foram. Res., v. 5, p. $6-17$.

1930. Miocene foraminifera from Buff Bay, Jamaica: J. Paleont., v. 4, p. 353-368. 1936. Three new foraminifera from the Miocene Bowden marl of Jamaica: Contrib. Cushman Lab. Foram. Res., v. 12, pt. 1, p. 3-5.

Cushman, J. A. and Ponton, G. M., 1932. Foraminifera of the upper, middle, and part of the lower Miocene of Florida: Florida Geol. Surv. Bull. 9, p. 1-147.

Cushman, J. A. and Ponton, G. M., 1932. An Eocene foraminiferal fauna of Wilcox age from Alabama: Contrib. Cushman Lab. Foram. Res., v. 8, p. 51-72.

Cushman, J. A. and Renz, H. H., 1942. Eocene, midway, foraminifera from Soldado Rock, Trinidad: Contrib. Cushman Lab. Foram. Res., v. 18, p. 1-14.

Cushman, J.A. and Stainforth, R. M., 1945. The foraminifera of the Cipero Marl Formation of Trinidad, British West Indies: Cushman Lab. Foram. Res., Special Publ. 14, p. 1-74.

Eames, F. E., Banner, F. T., Blow, W. H., and Clarke, W. J., 1962. Fundamentals of mid-Tertiary stratigraphic correlation: Cambridge England (Cambridge University Press).

Edgar, T., Saunders, J., Donnelly, T., Schneidermann, N., Maurrasse, F., Bolli, H., Hay, W., Riedel, W., Premoli Silva, I., Boyce, R., and Prell, W. 1971. Deep Sea Drilling Project, Leg 15. Geotimes (April).

Egger, J. G., 1893. Foraminifera aus Meeresgrund-proben, gelothet von 1874 bis 1876 von S. M. Sch. "Gazelle": Abhandl. K. Bayer. Akad. Wiss. München, CLII, v. 18, p. $195-458$.

Ellis, B. F. and Messina, A. R., 1940, etc., A catalogue of foraminifera: Am. Mus. Nat. Hist. Spec. Publ. (30 vols. and supplements).

El-Naggar, Z. R. 1966. Stratigraphy and planktonic foraminifera of the Upper Cretaceous - Lower Tertiary succession in the Esna-Idfu region, Nile valley, Egypt, UAR: Brit. Mus. (Nat. Hist.), Geol. Bull., Suppl. 2.

Fahmy, S. E., Krasheninnikov, V. A., Mikhailov, I. A., and Samodurov, V. I., 1969. Biostratigraphy of Paleogene deposits in Egypt: African Micropaleont. Colloq., 3d, Cairo, Proc., P. 477.

Finlay, H. J., 1939, New Zealand foraminifera, key species in stratigraphy: Roy. Soc. New Zealand, Trans., v. 69, pt. 1, p. 89-128.

1947. New Zealand foraminifera, key species in stratigraphy: New Zealand J. Sci. Tech., v. 28 , no. 5, sec. B, p. 259-292.

Fischer, A. G., Heezen, B. C., Boyce, R. E., Bukry, D., Douglas, R. G., Garrison, R. E., Kling, S. A., Krasheninnikov, V. A., Lisitzin, A. P., Pimm, A. C., 1971. Initial Reports of the Deep Sea Drilling Project, Volume VI: Washington (U. S. Government Printing Office).

Fornasini, C., 1899. Globigerina adriatiche: Mem. R. Acc. Sc. Bologna, v. 7, p. 3-14.

Galloway, J. J. and Wissler, S. G., 1927. Pleistocene foraminifera from the Lomita Quarry, Palos Verdes Hills, California: J. Paleont., v. 1, p. 35-87.

Glaessner, M. F., 1937. Planktonforaminiferen aus der Kreide und dem Eozän und ihre stratigraphische Bedeutung: Moscow Univ., Lab. Paleont., Studies Micropaleont., v. 1, pt. 1, p. 27-46.

Hedberg, H. D., 1937. Foraminifera of the middle Tertiary Carapita Formation of northeastern Venezuela: J. Paleont., v. 11 , no. 8, p. 661-697. 
Jenkins, D. G., 1965. A re-examination of Globorotalia collactea Finlay, 1939: New Zealand J. Geol. Geophys., v. $8(5)$, p. 843 .

, 1971. New Zealand Cenozoic planktonic foraminifera: New Zealand Geol. Surv. Paleont. Bull., v. 42.

Khalilov, D. M., 1956. On a pelagic foraminiferal fauna of Paleogene deposits of Azerbaidzhan: Akad. Nauk. Azerbaidzhanskoi SSR, Inst. Geol., Trudy, v. 17, p. 234-255.

Koch, R., 1926. Mitteltertiäre Foraminiferen aus Bulongan, Öst-Borneo: Ecl. Geol. Helv., 19, 722.

Krasheninnikov, V. A., 1964. Significance of planktonic foraminifera of open tropical basins of the Danian and Paleogene time for the creation of the international stratigraphic scale (in Russian): Voprosi Micropaleontol., v. 8, p. 190.

1965. Zonal Paleogene stratigraphy of the eastern Mediterranean (in Russian): Geol. Inst. Acad. Sci. USSR trans., v. 133.

1971. Stratigraphy and foraminifera of the Cenozoic pelagic sediments of the Pacific northwestern part (based on materials of deep-sea drilling) (in Russian): Voprosi Micropaleontol., v. 14, p. 140.

Krasheninnikov, V. A. and Abdel Razik, T. M., 1969. Zonal stratigraphy of the Paleocene in Qusseir, Red Sea Coast: African Micropaleont. Colloq., 3d, Cairo Proc., 299.

Le Roy,L.W.,1939. Some small foraminifera, Ostracoda and otoliths from the Neogene ("Miocene") of the RokanTapanoeli area, central Sumatra: Natuurk. Tijdschr. Nederl.-Indie, v. 99, no. 6, p. 215-296.

, 1944. Miocene foraminifera of central Sumatra, Netherlands East Indies: Colorado School Mines, Quart., v. 39 , no. 3 , pt. 1 , p. $9-69$.

, 1953. Biostratigraphy of the Magfi section, Egypt: Geol. Soc. Am., Mem. 54, p. 1-73.

Loeblich, A. R., Jr. and Tappan, H., 1957. Planktonic foraminifera of Paleocene and early Eocene age from the Gulf and Atlantic coastal plains: U. S. Natl. Mus. Bull. 215, p. 173-198.

Luterbacher, H. P. and Premoli Silva, I., 1964. Biostratigrafia del limite Cretaceo-Terziario nell'Apennino Centrale: Riv. Ital. Paleont., v. 70, p. 67-128.

Martin, L. T., 1943. Eocene foraminifera from the type Lodo formation, Fresno County, California: Stanford Univ., Ser. Geol. Sci., v. 3, p. 117.

Morozova, V. G., 1939. The stratigraphy of the Upper Cretaceous and Lower Tertiary deposits in the Emba oilbearing district according to the foraminiferal fauna (in Russian): Soc. Nat. Moscow, Bull., n.s., v. 47, p. 80 .

Nevzorova, L. S., 1971. Sediments of the western KopetDag ridge analogous to the Italian Globigerina eugubina Zone of the Danian stage (in Russian). 2d Sci. Conf. Geol. Dept. Turcmenian SSR., v. 36.

Nuttall, W. L. F., 1930. Eocene foraminifera from Mexico: J. Paleont., v. 4, p. 271-293.

Orbigny, A. D. d', 1826. Tableau Méthodique de la classe des Céphalopodes: An. Sci. Nat., Paris, ser. 1, v. 7, p. 96-314.
1839. Foraminifères. In de la Sagra, R., Histoire physique, politique et naturelle de l'ile de Cuba: Paris (Bertrand) p. 1-224.

1846. Foraminifères fossiles du Bassin Tertiaire de Vienne (Autriche): Paris (Gide and Comp.) p. 1-303.

Palmer, D. K., 1945. Notes on the foraminifera from Bowden, Jamaica: Bull. Am. Paleont., v. 29, p. 1-82.

Parker, F. L., 1965. A new planktonic species (Foraminiferida) from the Pliocene of Pacific deep-sea cores: Contrib. Cushman Found. Foram. Res., v. 16, p. 151-152.

Parker, W. K. and Jones, T. R., 1865. On some foraminifera from the North Atlantic and Arctic oceans, including Davis Straits and Baffin's Bay: Roy. Soc. London, Phil. Trans., v. 155 , p. $325-441$.

Reiss, Z., 1957. Notes on Foraminifera from Israel. 1. Remarks on Truncorotalia aragonensis caucasica (Glaessner): Israel Geol. Survey Bull. 9, i.

Reuss, A. E., 1850. Neues Foraminiferen aus den Schichten des österreichischen Tertiärbeckens: K. Akad. Wiss. Wien, Math.-Naturwiss. Cl., Denkschr., v. 1, p. 365-390.

Saito, T., 1962. Eocene planktonic foraminifera from Hahajima (Hilsborough Island): Palaeont. Soc. Japan, Trans. and Proc., new ser., no. 45, p. 209-225.

Saribekyan, A. D., 1964. Representatives of A carinina from the Lower and Middle Eocene sediments of the Nalchik region (North Caucasus) (in Russian): Acad. Sci. Armenian SSR Trans., v. 17 (6).

Schubert, R. J., 1910. Über foraminiferen und einen Fischotoliten aus dem fossilen Globigerinenschlamm von NeuGuinea: Geol. Reichsanst., Verhandl, Vienna, p. 318-328.

Subbotina, N. N., 1947. Danian and Paleogene foraminifera of the northern Caucasus (in Russian): Leningrad, Vses. Neft. Nauchno-Issled. Geol.-Razved. Inst. (VNIGRI), p. 108 .

1950. Microfauna and stratigraphy of the Elburgansk horizon and the horizon of the Goryachij Klyuchj. In Microfauna of the U.S.S.R.: v. 4, p. 5-12.

, 1953. Globigerinidae, Hantkeninidae, and Globorotaliidae: fossil foraminifera of the USSR: VNIGRI, Trudy, n. ser., no. 76, pp. 1-296.

Takayanagi, Y. and Saito, T., 1962. Planktonic foraminifera from the Nobori Formation, Shikoku, Japan: Tohoku Univ., Sendai, Japan, Sci. Repts., 2d Ser. (Geol.), Spec. v. 5 , p. 67-106.

Todd, R., 1957. Geology of Saipan, Mariana Islands: smaller foraminifera: U.S. Geol. Surv. Prof. Paper 280-H. p. 165-320.

Toulmin, L. D., 1941. Eocene smaller foraminifera in the Salt Mountain of Alabama: J. Paleont., v. 15, p. 567-611.

Toumarkine, M., Bolli, H. M., 1970. Evolution de Globorotalia cerroazulensis (Cole) dans l'Eocéne moyen et supérieur de Possagno (Italie). Rev. Micropaleont., v. 13 (3), p. 131.

White, M. P., 1928. Some index foraminifera of the Tampico embayment area of Mexico: J. Paleont., v. 2, p. 280-317. 


\section{PLATE 1}

Figures 1-3 Acarinina acarinata Subbotina. Site 199, Core 8. Globorotalia velascoensis Zone; late Paleocene.

1. Umbilical view, $X 185$.

2. Spiral view, $X 170$.

3. Side view, $\times 160$.

Figures 4-6 Acarinina broedermanni (Cushman and Bermudez). Site 200A, Core 2, core catcher; Globorotalia formosa formosa Zone; early Eocene.

4. Umbilical view, $X 155$.

5. Spiral view, $X 170$.

6. Side view, $\times 155$.

Figures 7-9 Acarinina decepta (Martin). Site 200A, Core 2, core catcher; Globorotalia formosa formosa Zone; early Eocene.

7. Umbilical view, $X 110$.

8. Spiral view, $\times 100$.

9. Side view, $\times 105$.

Figures 10-12 Acarinina esnaensis (LeRoy). Site 200A, Core 2, core catcher; Globorotalia formosa formosa Zone; early Eocene.

10. Umbilical view, $\times 165$.

11. Spiral view, $\times 165$.

12. Side view, $X 110$. 


\section{PLATE 1}
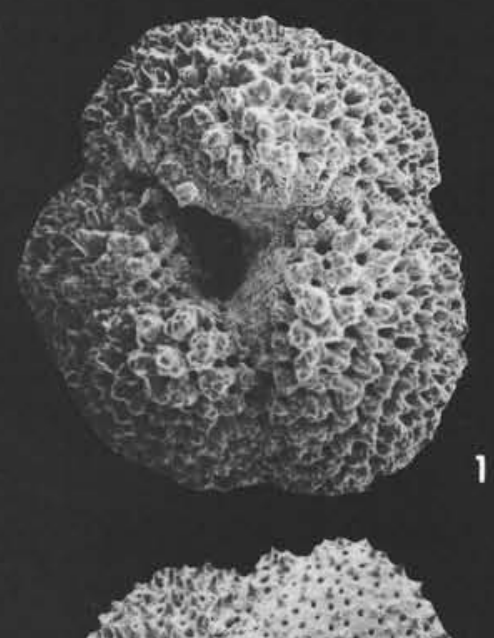

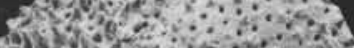

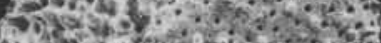

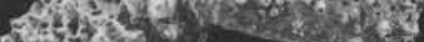
finteres Q5x

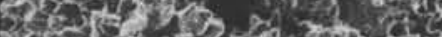

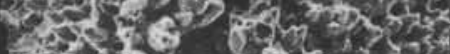

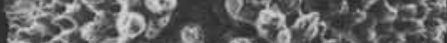

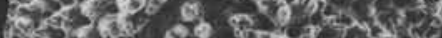

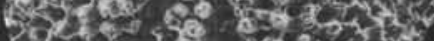

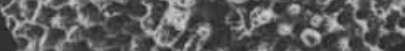
$23 x=56,+90,5$

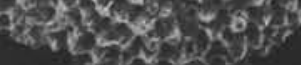

4

1
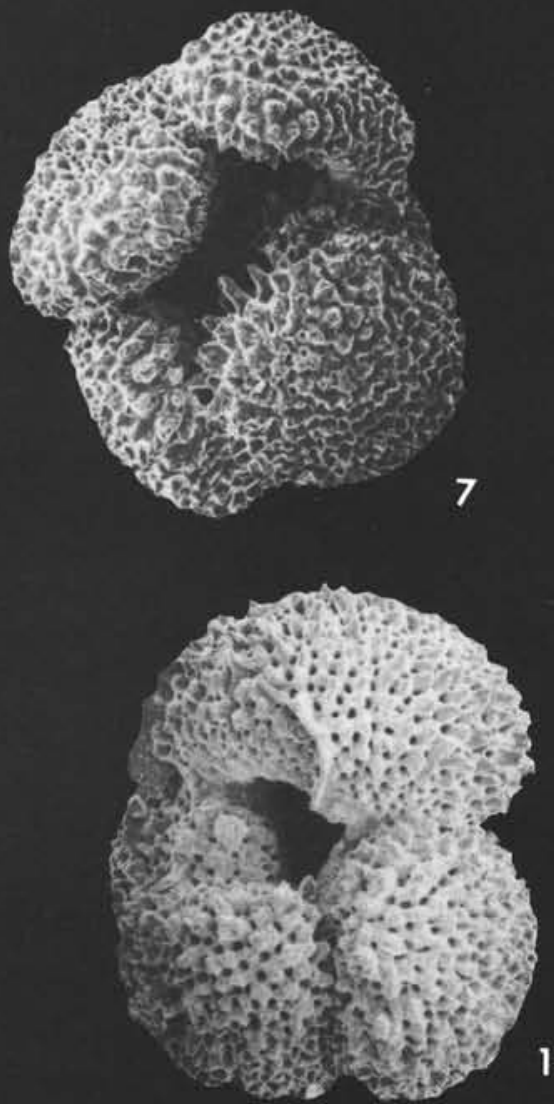

10
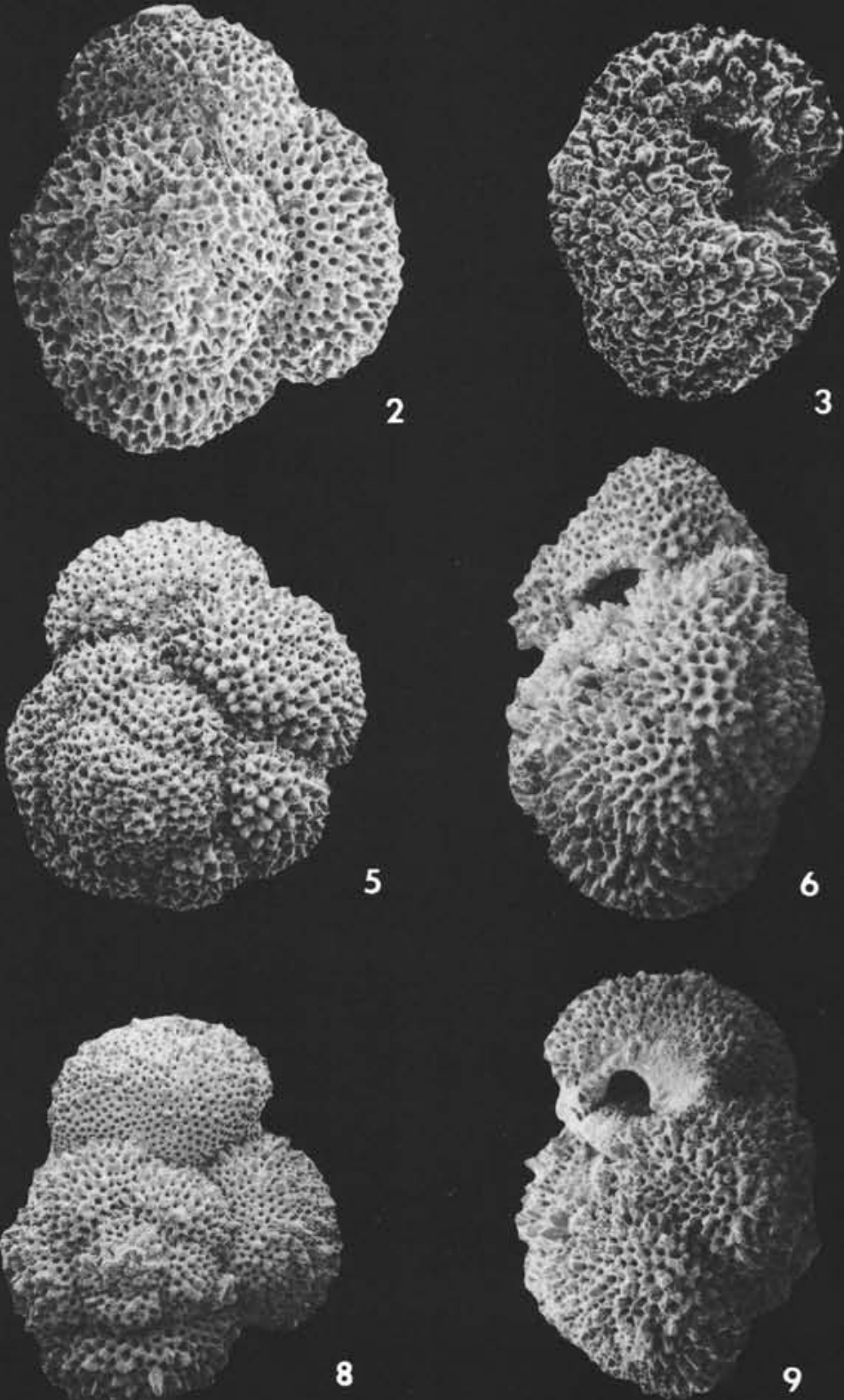

9

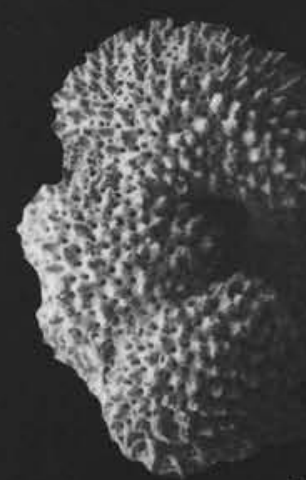

12 


\section{PLATE 2}

Figures 1-2 Acarinina gravelli (Bronnimann). Site 200A, Core 2; Globorotalia formosa formosa Zone; early Eocene.

1. Umbilical view, $\times 105$.

2. Side view, $\times 110$.

Figures 3-5 Acarinina intermedia Subbotina. Site 199, Core 8; Globorotalia velascoensis Zone; late Paleocene.

3. Umbilical view, $\times 140$.

4. Spiral view, $\times 150$.

5. Side view, $\times 140$.

Figures 6-8

Acarinina mckannai (White). Site 199, Core 8; Globorotalia velascoensis Zone; late Paleocene.

6. Umbilical view, $\times 155$.

7. Spiral view, $X 135$.

8. Side view, $\times 130$.

Figures 9-11 Acarinina pentacamerata camerata Khalilov. Site 200A, Core 2; Globorotalia formosa formosa Zone, early Eocene.

9. Umbilical view, $\times 105$.

10. Spiral view, $X 127$.

11. Edge view, $\times 127$. 
Plate 2
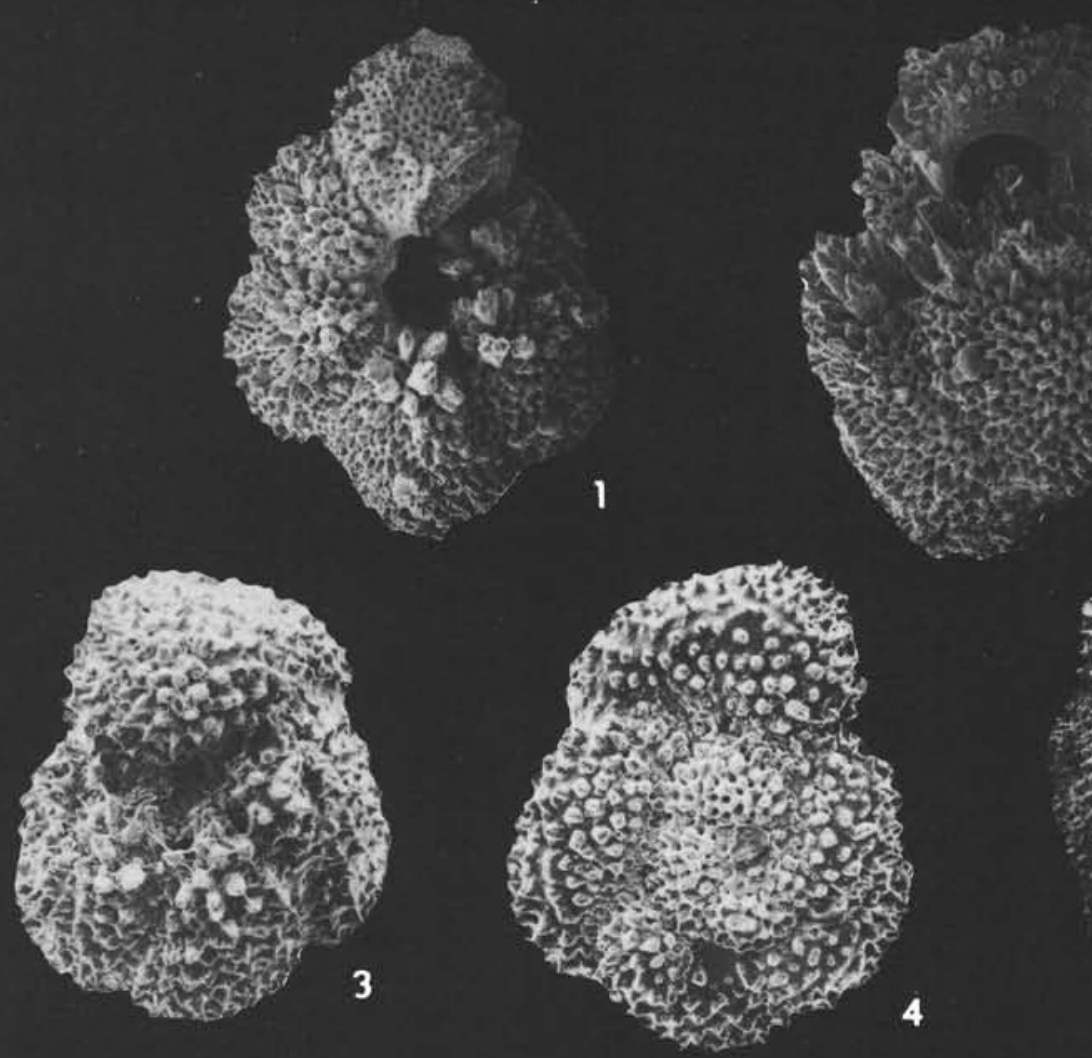

\section{2}

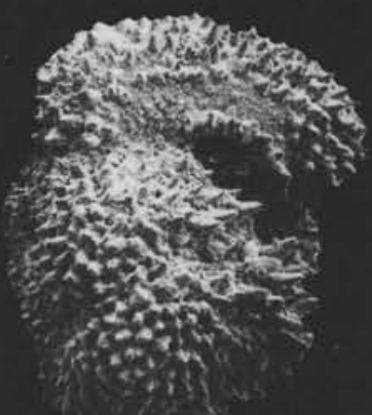

\section{5}
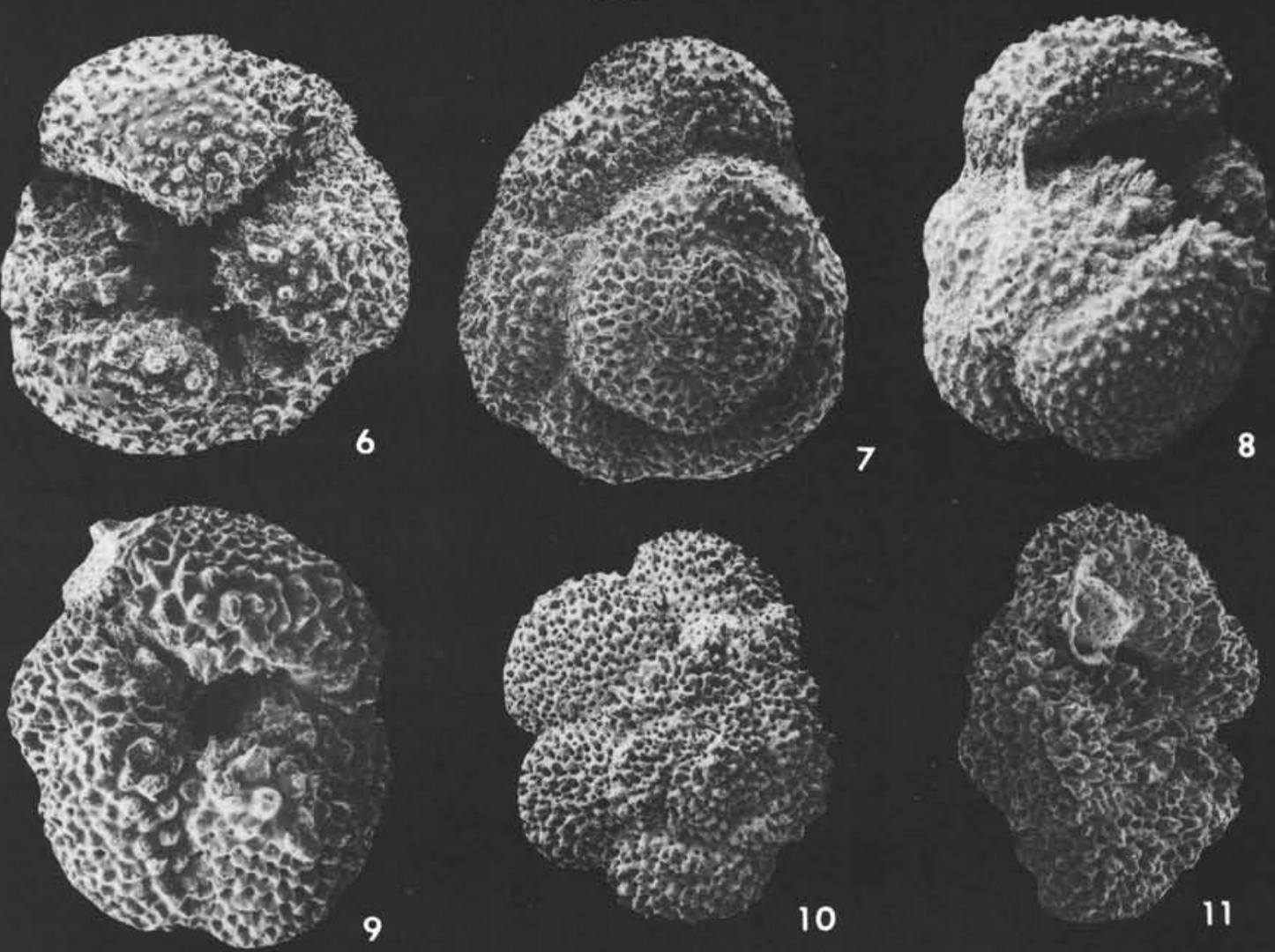


\section{PLATE 3}

Figures 1-3 Acarinina pentacamerata pentacamerata (Subbotina). Site 200A, Core 2, core catcher; Globorotalia formosa formosa Zone; early Eocene.

1. Umbilical view, $X 35$.

2. Spiral view, $\times 90$.

3. Side view, $\times 100$.

Figures 4-6 Acarinina primitiva (Finlay). Site 199, Core 8; Globorotalia velascoensis Zone; late Paleocene.

4. Umbilical view, $X 165$.

5. Spiral view, $\times 165$.

6. Side view, $\times 155$,

Figures 7-9 Acarinina pseudotopilensis Subbotina. Site 200A, Core 2, core catcher; Globorotalia formosa formosa Zone; early Eocene.

7. Umbilical view, $X 125$.

8. Spiral view, $X 170$.

9. Side view, $\times 120$.

Figures 10-12 Acarinina soldadoensis (Bronnimann). Site 200A, Core 2, core catcher; Globorotalia formosa formosa Zone; early Eocene.

10. Umbilical view, $X 150$.

11. Spiral view, $X 140$.

12. Side view, $X 150$. 


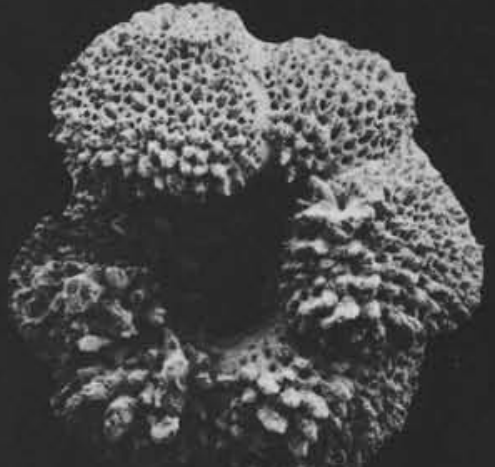

1

\section{PLATE 3}

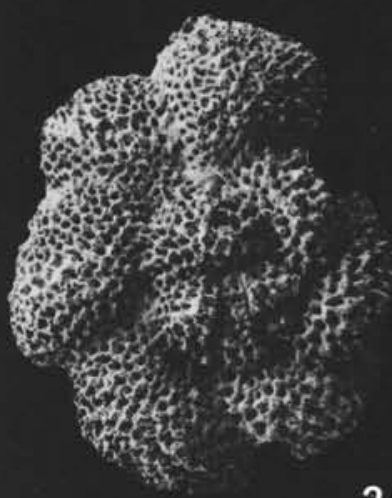

2

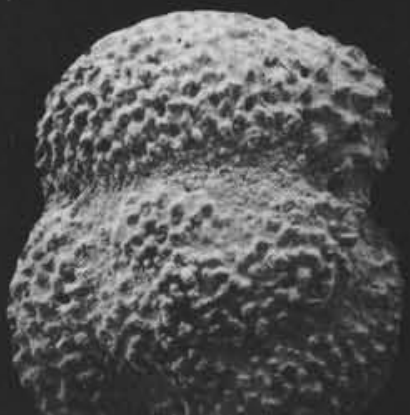

5

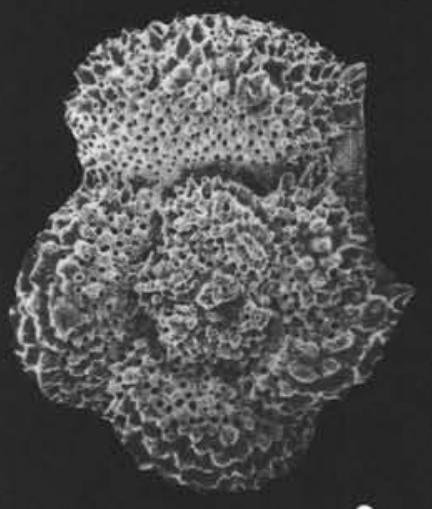

8

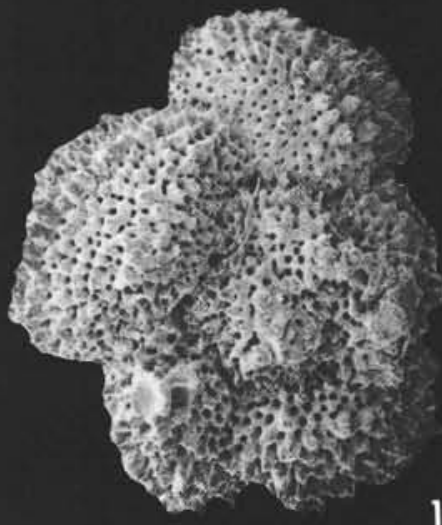

11
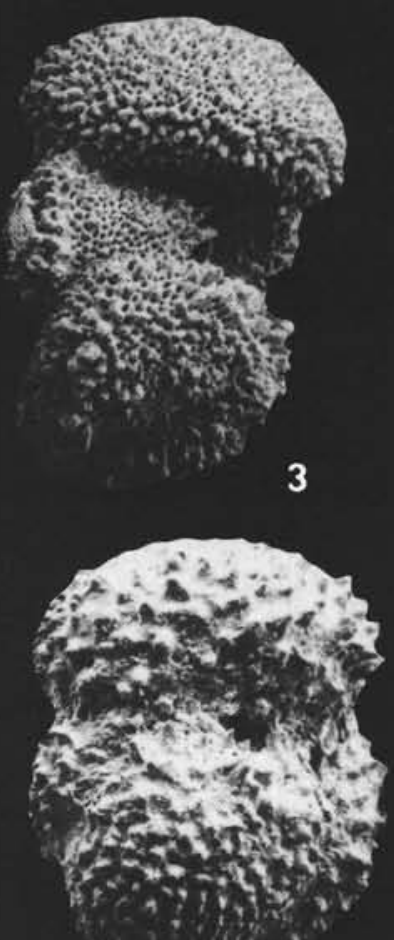

6
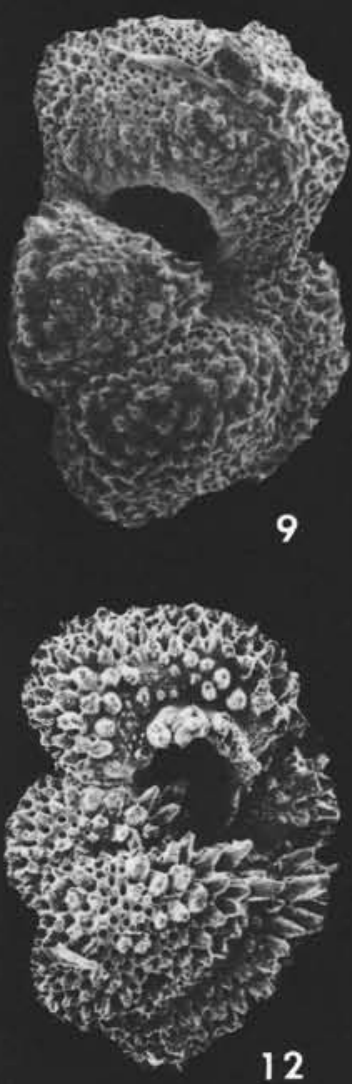


\section{PLATE 4}

Figures 1-3 Acarinina triplex Subbotina. Site 200A, Core 2, core catcher; Globorotalia formosa formosa Zone; early Eocene.

1. Umbilical view, $\times 135$.

2. Spiral view, $X 120$.

3. Side view, $\times 125$.

Figure 4 Biobulina bilobata (d'Orbigny); $\times 54$. Site 200, Core 6 , core catcher; Globorotalia acostaensis-Globorotalia merotumida Zone; late Miocene.

Figure 5 Candeina nitida d'Orbigny; $\times 120$. Site 200, Core 3, core catcher; Sphaeroidnella dehiscens-Globoquadrina altispira Zone; early Pliocene.

Figure 6 Candeina $\mathrm{cf}$ praenitida Blow; $\times 230$. Site 200, Core 6, core catcher; Globorotalia acostaensis-Globorotalia merotumida Zone; late Miocene.

Figures 7-9 Cassigerinella chipolensis (Cushman and Ponton). Figure 7, X275; Figure 8, X250; Figure 9, X275. Site 200, Core 10, core catcher (hard limestone); Globigerinatella insueta-Globigerinita dissimilis Zone; early Miocene.

Figures 10-11 Chiloguembelina parallela Beckmann. Site 200A, Core 2, core catcher; Globorotalia formosa formosa Zone; early Eocene.

10. Apertural view, $\times 190$.

11. Side view, $X 165$. 
PLATE 4
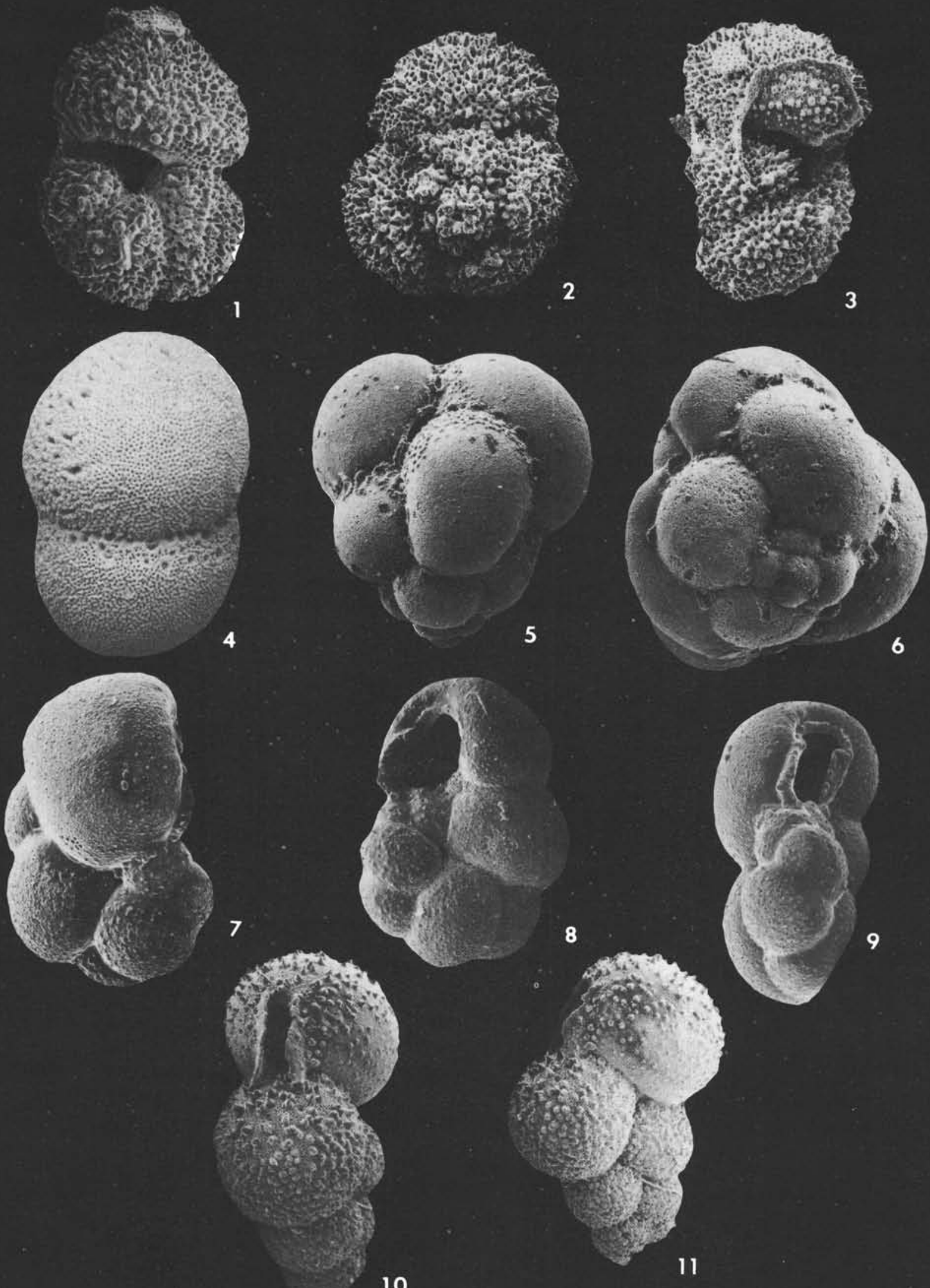

10 


\section{PLATE 5}

Figure $1 \quad$ Chiloguembelina taurica Morozova; X200. Site 199, Core 10-11; "Globigerina" eugubina Zone.

Figures 2-3 Chiloguembelina wilcoxensis (Cushman and Ponton). Site 200A, Core 2, core catcher; Globorotalia formosa formosa Zone; early Eocene.

2. Edge view, $\times 155$.
3. Side view, $\times 145$.

Figures 4-5 Globigerapsis index (Finlay). Site 202, Core 2, core catcher; Orbulinoides beckmanni Zone; middle Eocene.

4. Umbilical view, $\times 140$.

5. Spiral view, $X 145$.

Figures 6-7 Globigerapsis kugleri Bolli, Loeblich, and Tappan. Site 202, Core 2, core catcher, Orbulinoides beckmanni Zone; middle Eocene.
6. $\times 83$.
7. $\times 84$.

Figures 8-10 Globigerina angustiumbilicata Bolli. Site 200, Core 10, core catcher (hard limestone); Globigerinatella insueta-Globigerinita dissimilis Zone, early Miocene.

8. Umbilical view, $\times 250$.

9. Spiral view, $\times 225$.

10. Side view, $X 260$. 


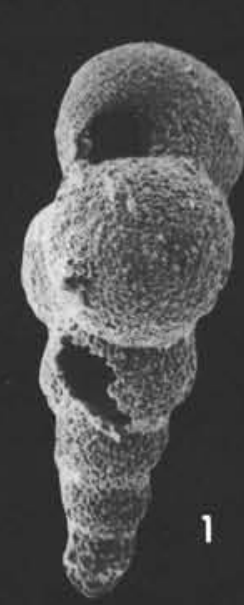

PLATE 5
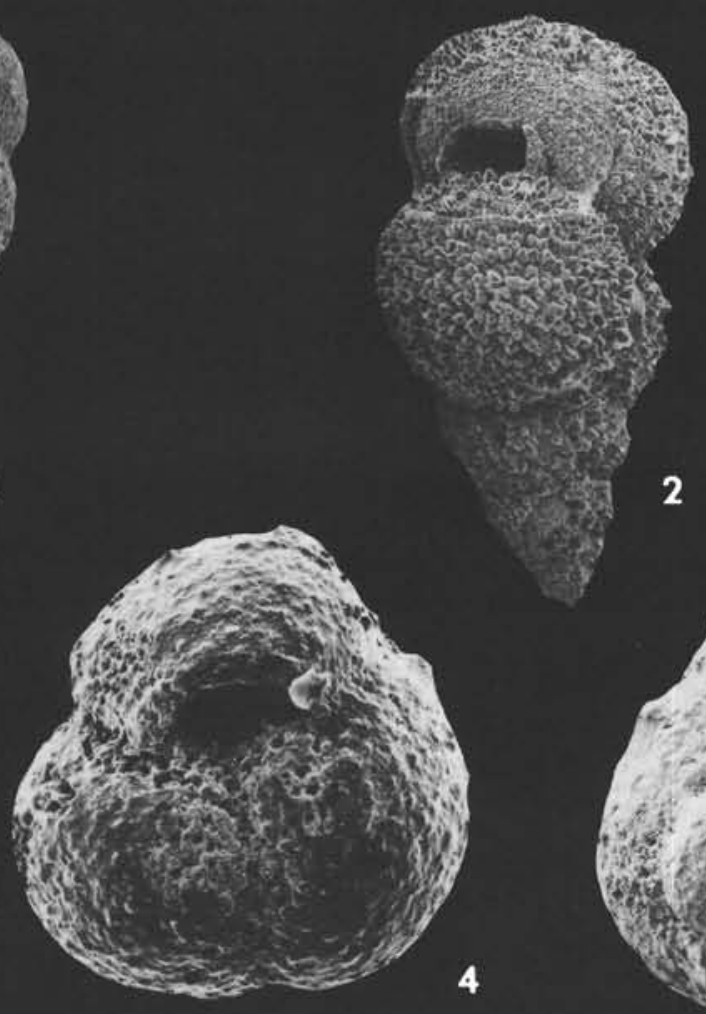

2
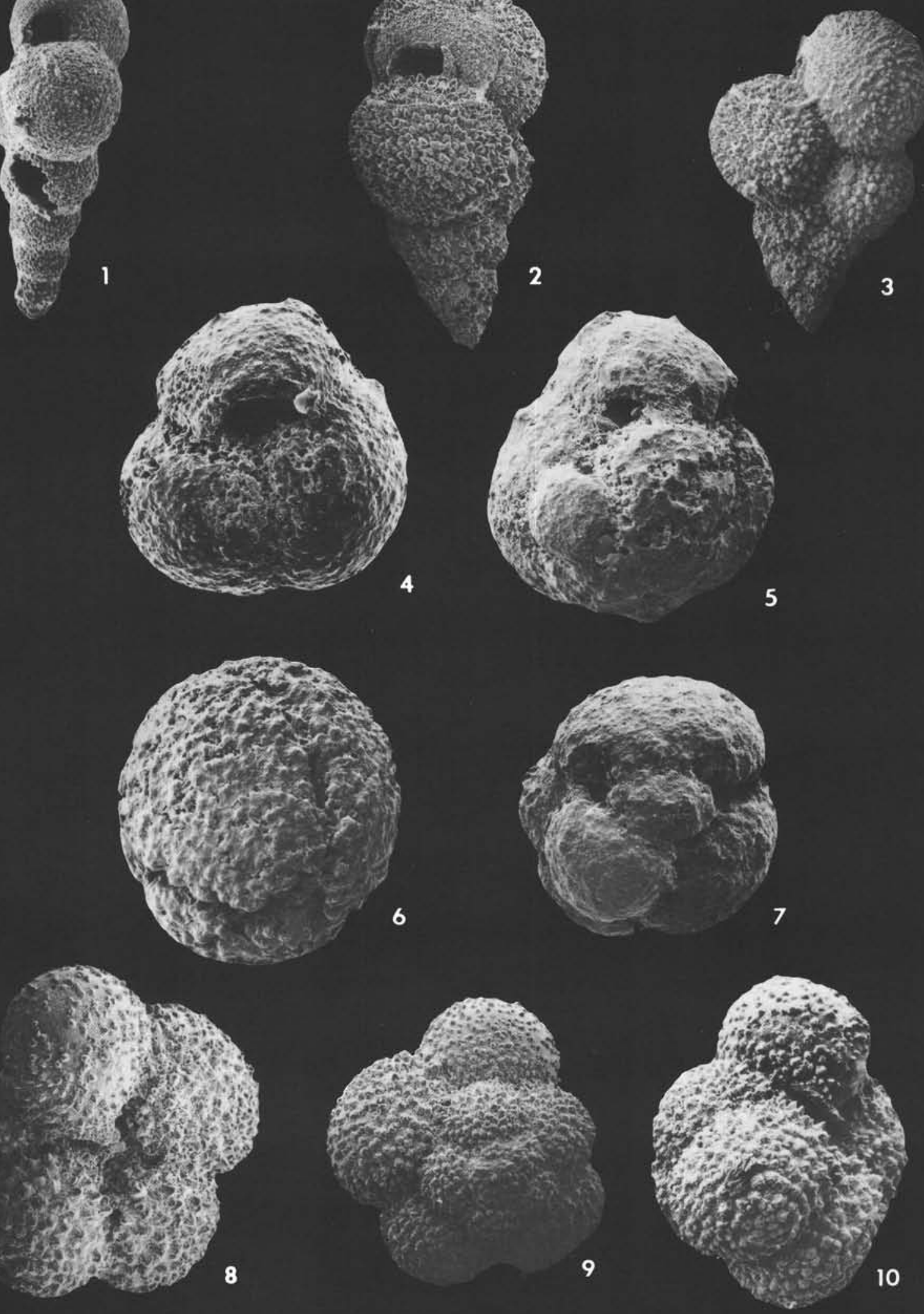


\section{PLATE 6}

Figures 1-3 Globigerina binaensis Koch. Site 200, Core 10, core catcher (hard limestone); Globigerinatella insuetaGlobigerinita dissimilis Zone; early Miocene.

1. Umbilical view, $\times 115$.

2. Spiral view, $\times 110$.

3. Side view, $\times 140$.

Figures 4-6 Globigerina bollii Cita and Silva. Site 200, Core 10, core catcher (hard limestone); Globigeriniatella insueta-Globigerinita dissimilis Zone. early Miocene.

4. Umbilical view, $\times 94$.

5. Spiral view, $\times 89$.

6. Side view, $\times 94$.

Figures 7-8 Globigerina bradyi Wiesner. Site 200, Core 10, core catcher (hard limestone); Globigerinatella insuetaGlobigerinita dissimilis Zone, early Miocene.

7. Apertural view, $\times 260$.

8. Apertural view, $\times 195$.

Figures 9-11 Globigerina bulbosa LeRoy. Site 200, Core 6, core catcher; Globorotalia acostaensis-Globorotalia merotumida Zone; late Miocene.

9. Umbilical view, $X 115$.

10. Spiral view, $\times 105$.

11. Side view, $X 115$. 

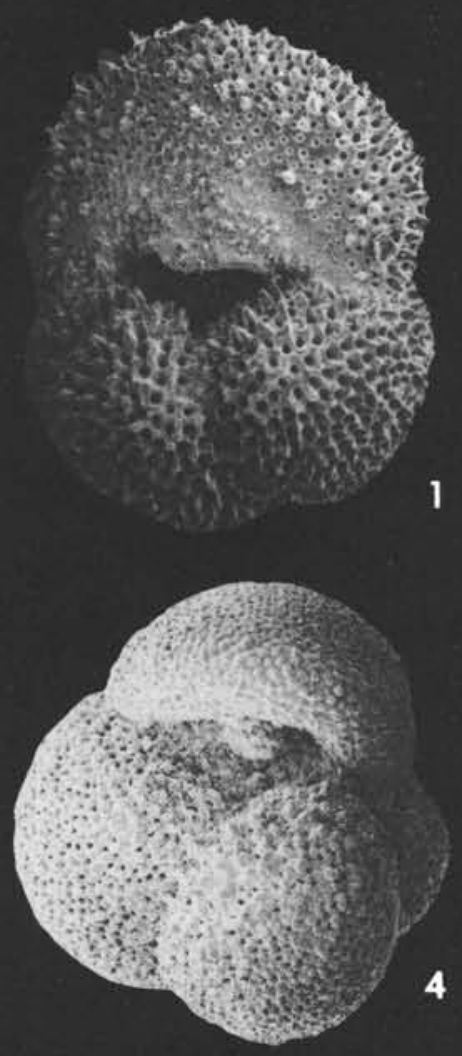

4
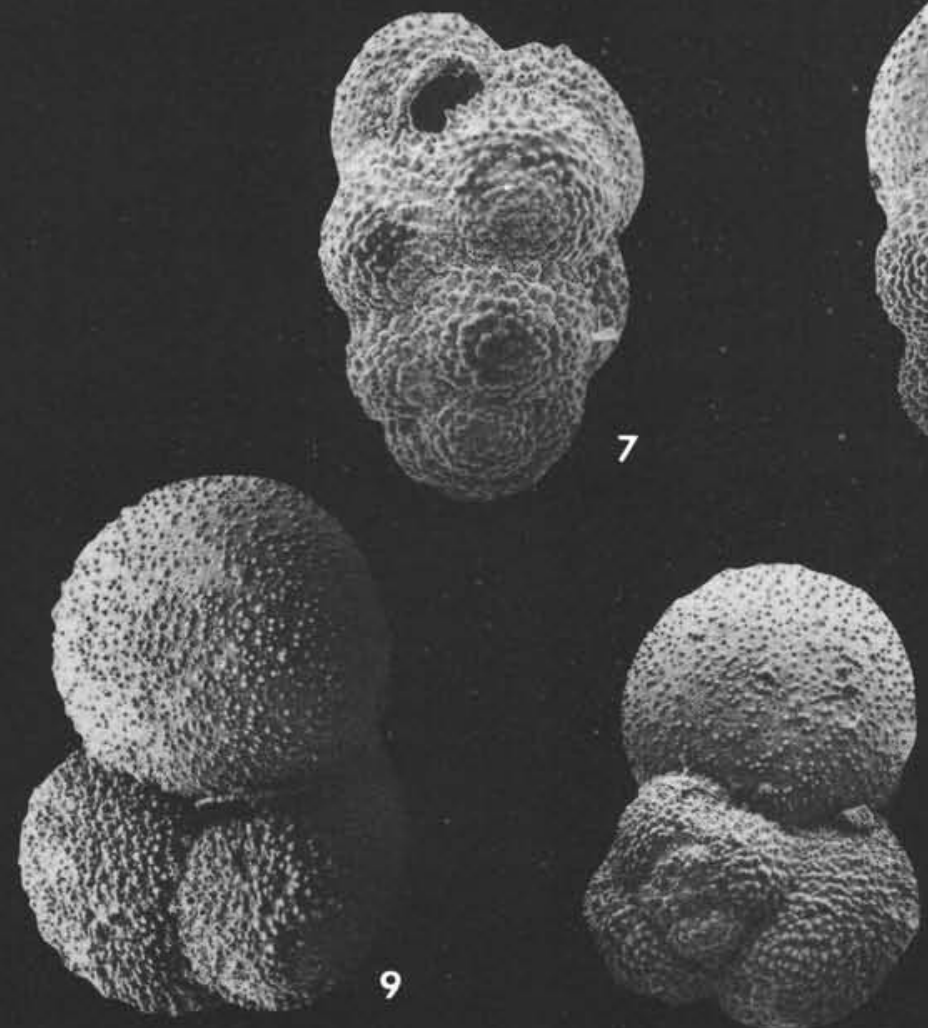

9

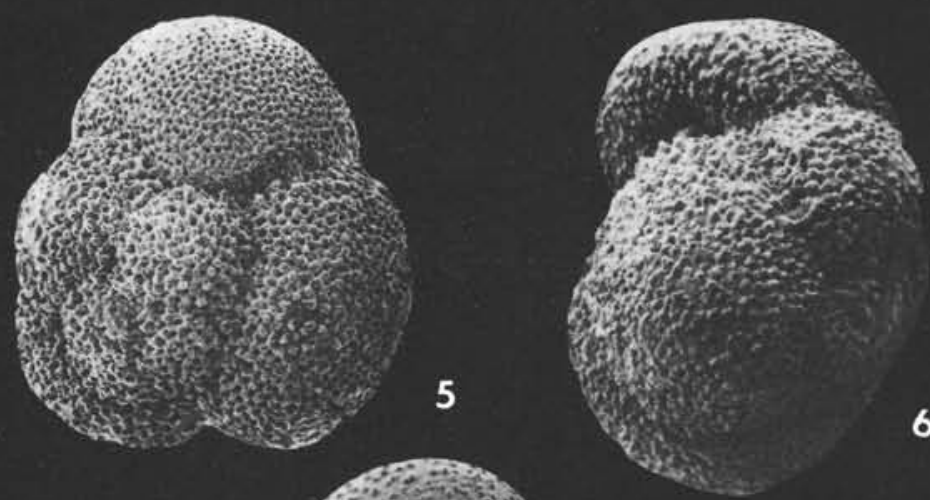

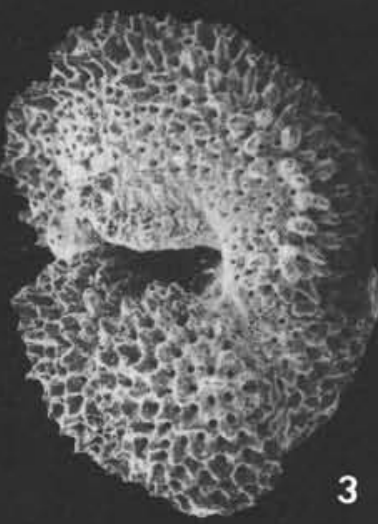


PLATE 7

Figures 1-2 Globigerina decoraperta Takayanagi and Saito. Site 200, Core 6, core catcher; Globorotalia acostaensisGloborotalia merotumida Zone; late Miocene.

1. Umbilical view, $\times 250$.

2. Spiral view, $\times 250$.

Figures 3-5 Globigerina eamesi Blow. Site 200, Core 6, core catcher; Globorotalia acostaensis-Globorotalia merotumida Zone; late Miocene.

3. Umbilical view, $\times 150$.

4. Spiral view, $X 175$.

5. Side view, $\times 165$.

Figures 6-8 Globigerina eugubina Luterbacher and Premoli Silva. Site 199, Core 10, Section 2; "Globigerina" eugubina Zone.

6. Umbilical view, $\times 350$.

7. Spiral view, $\times 350$.

8. Side view, $\times 350$.

Figures 9-11 Globigerina falconensis Blow. Site 200, Core 1, Section 1; Globorotalia truncatulinoides Zone; Pleistocene.

9. Umbilical view, $\times 70$.

10. Spiral view, $\times 70$.

11. Edge view, $\times 70$. 


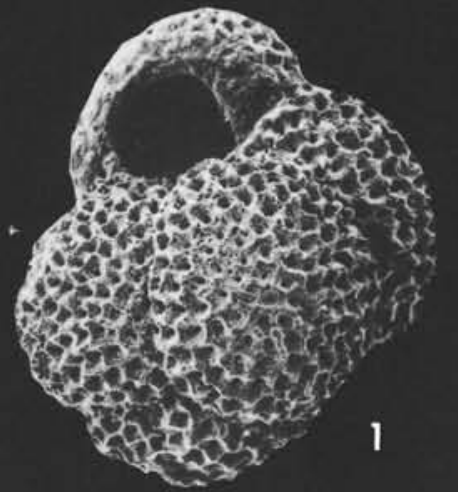

PLATE 7
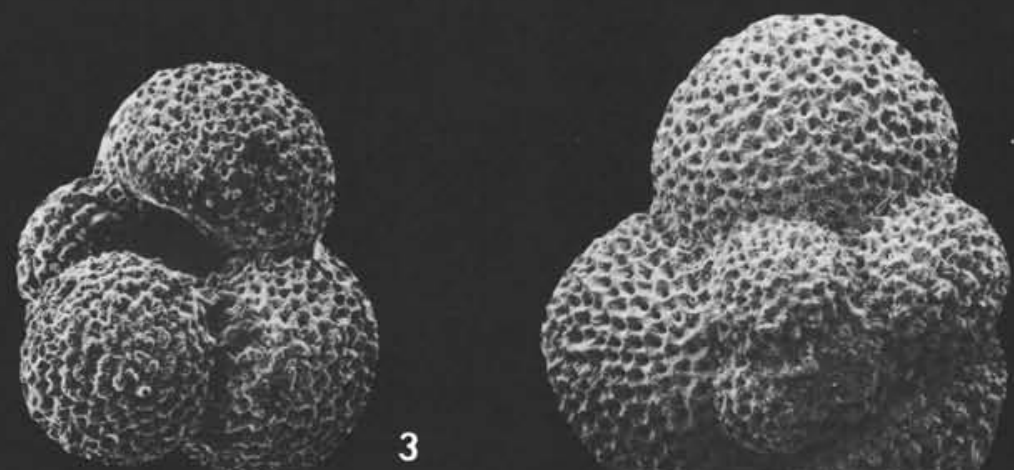

4
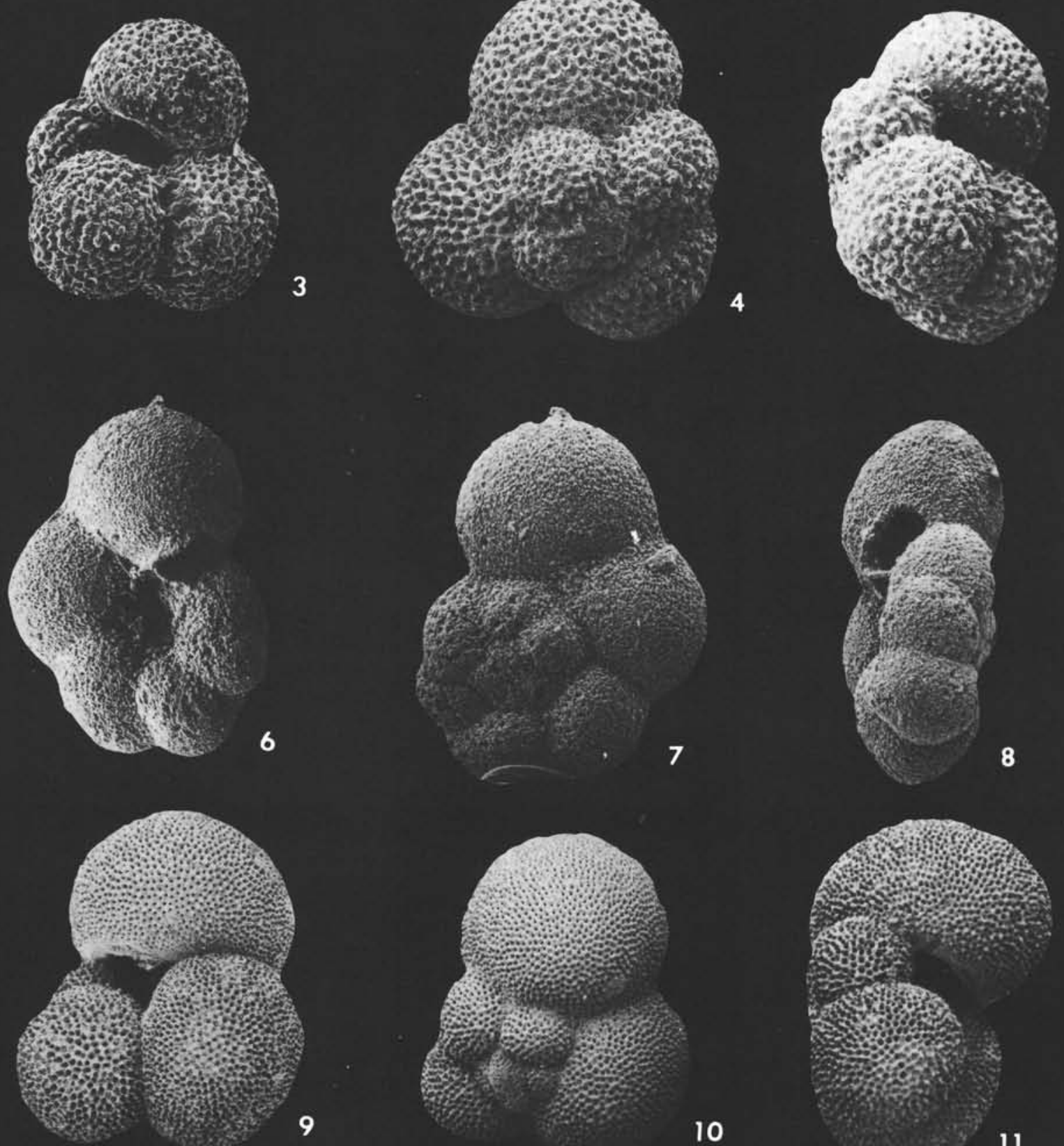

10 


\section{PLATE 8}

Figures 1-2 Globigerina aff. fringa Subbotina. Site 199, Core 10, Section 2; "Globigerina" eugubina Zone.

1. Umbilical view, $\times 375$.

2. Side view, $\times 375$.

Figures 3-5 Globigerina galavisi Bermudez. Site 202, Core 2, core catcher; Orbulinoides beckmanni Zone; middle Eocene.

3. Umbilical view, $\times 120$.

4. Spiral view, $X 110$.

5. Side view, $X 110$.

Figure 6 Globigerina juvenilis Bolli; Umbilical view, X 200. Site 200, Core 10, core catcher (hard limestone); Globigerinatella insueta-Globigerinita dissimilis Zone; early Miocene.

Figures 7-8 Globigerina microstoma Cita, Premoli Silva, and Rossi. Site 200, Core 6, core catcher; Globorotalia acostaensis-Globorotalia merotumida Zone, late Miocene.

7. Umbilical view, $\times 270$.

8. Spiral view, $\times 290$.

Figures 9-11 Globigerina minutula Luterbacher and Premoli Silva. Site 199, Core 10, Section 2; "Globigerina" eugubina Zone.

9. Umbilical view, $\times 450$.

10. Spiral view, $\times 450$.

11. Side view, $\times 450$. 
PLATE 8
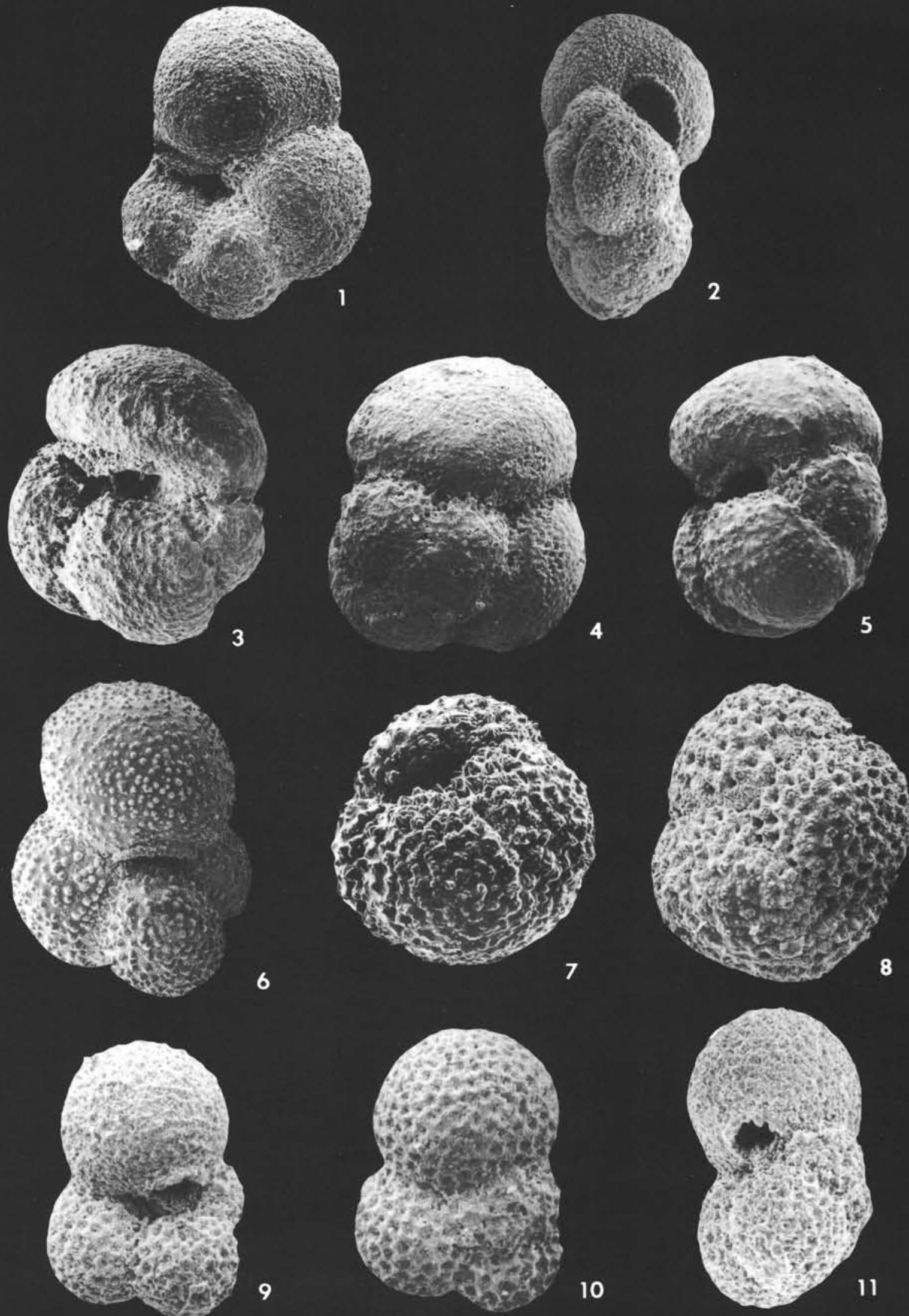

4
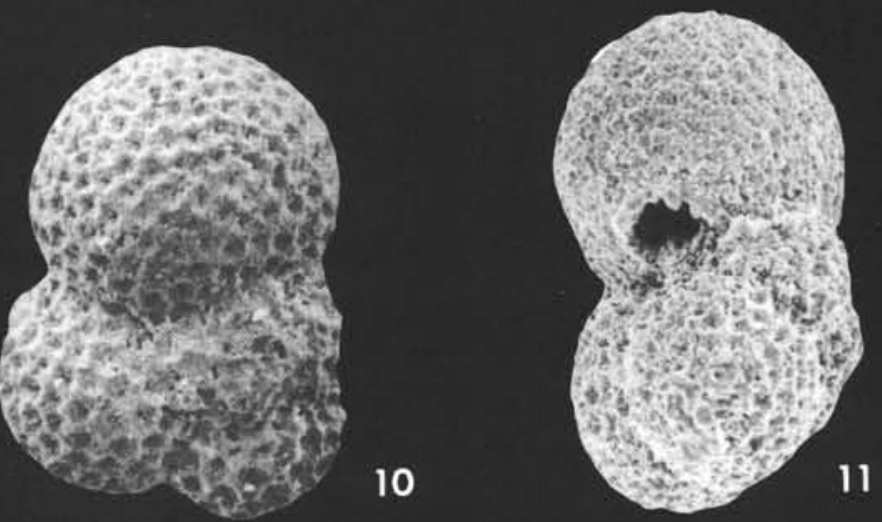


\section{PLATE 9}

Figures 1-3 Globigerina nana Khalilov. Site 199, Core 9; Globorotalia velascoensis Zone; late Paleocene.

1. Umbilical view, $X 135$.

2. Spiral view, $X 140$.

3. Side view, $\times 140$.

Figures 4-6 Globigerina nepenthes Todd. Site 200; Figures 4-5, Core 4, Section 1, Globorotalia tumida-Sphaeroidinellopsis subdehiscens paenodehiscens Zone, early Pliocene; Figure 6, Globorotalia acostaensisGloborotalia merotumida Zone; late Miocene.

4. Umbilical view, $X 112$.

5. Spiral view, $X 135$.

6. Umbilical view, $X 165$.

Figures 7-9 Globigerina parabulloides Blow. Site 200, Core 6, core catcher; Globorotalia acostaensis-Globorotalia merotumida Zone; late Miocene.

7. Umbilical view, $\times 250$.

8. Spiral view, $\times 200$.

9. Side view, $\times 235$.

Figures 10-12 Globigerina praebulloides Blow. Site 200, Core 10, core catcher; Globigerinatella insueta-Globigerinita dissimilis Zone; early Miocene.

10. Umbilical view, $\times 265$.

11. Spiral view, $\times 175$.

12. Side view, $\times 265$. 


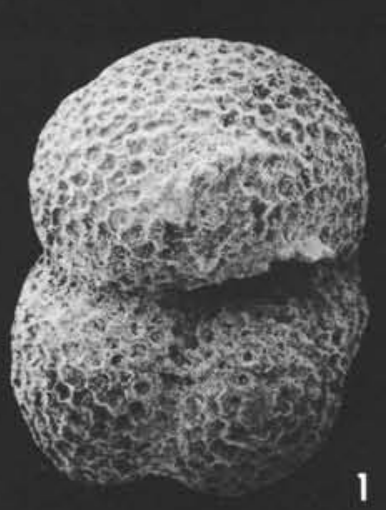

1
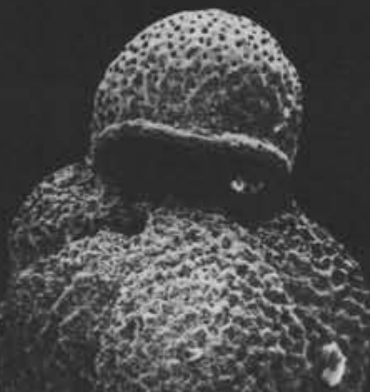

4
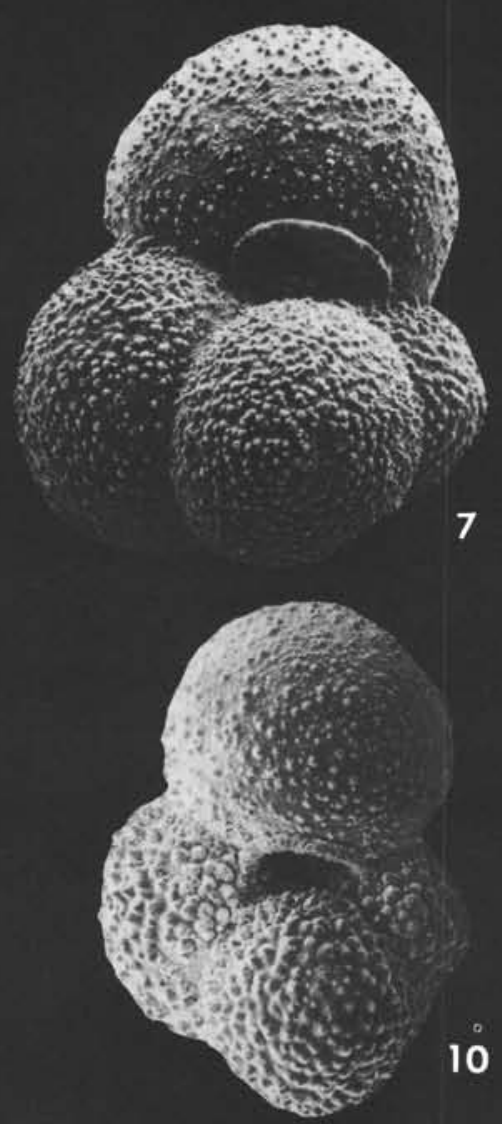

10
PLATE 9

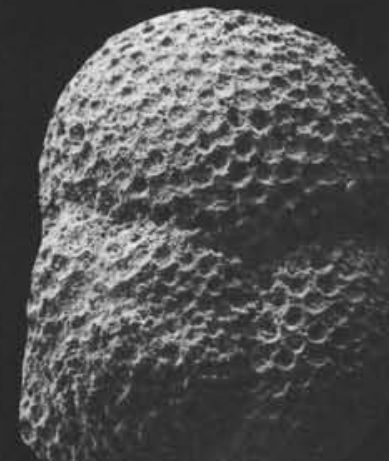

2

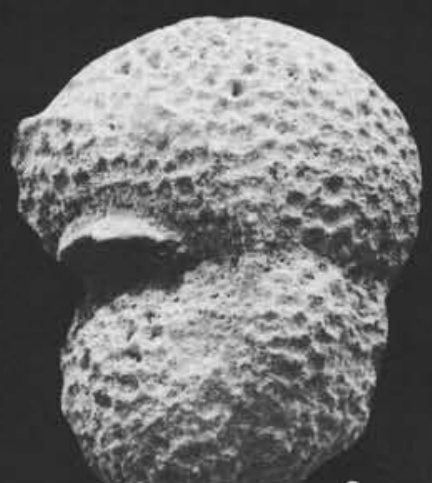

3
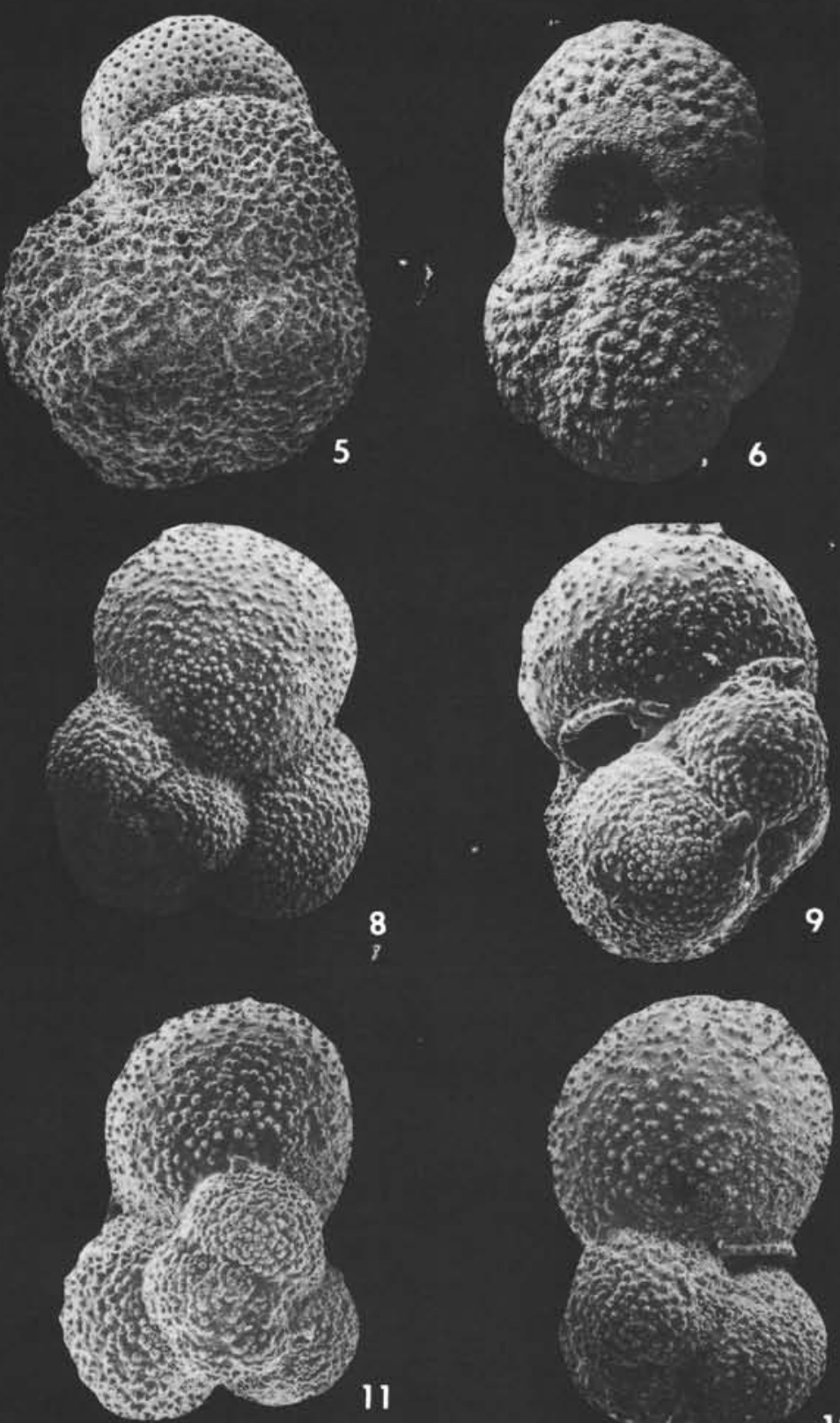
PLATE 10

Figure 1 Globigerina praedigitata Parker; umbilical view. Site 200, Core 1, Section 5; Globorotalia truncatulinoides Zone; Pleistocene.

Figures 2-3 Globigerina prolata Bolli. Site 200A, Core 2, core catcher: Globorotalia formosa formosa Zone; early Miocene.

2. Umbilical view, $\times 135$.

3. Side view, $X 135$.

Figures 4-6 Globigerina pseudoeocaena Subbotina. Site 202, Core 2, core catcher; Orbulinoides beckmanni Zone; middle Eocene.

4. Umbilical view, $\times 85$.

5. Spiral view, $\times 87$.

6. Side view, $\times 95$.

Figures 7-8 Globigerina pseudovenezuelana Blow and Banner. Site 202, Core 2, core catcher; Orbulinoides beckmanni Zone; middle Eocene.

7. Umbilical view, $\times 95$.

8. Spiral view, $\times 95$.

Figures 9-10 Globigerina rubescens Hofker. Site 200, Core 1, Section 2; Globorotalia truncatulinoides Zone; Pleistocene.

9. Umbilical view, $\times 250$.

10. Spiral view, $\times 250$. 

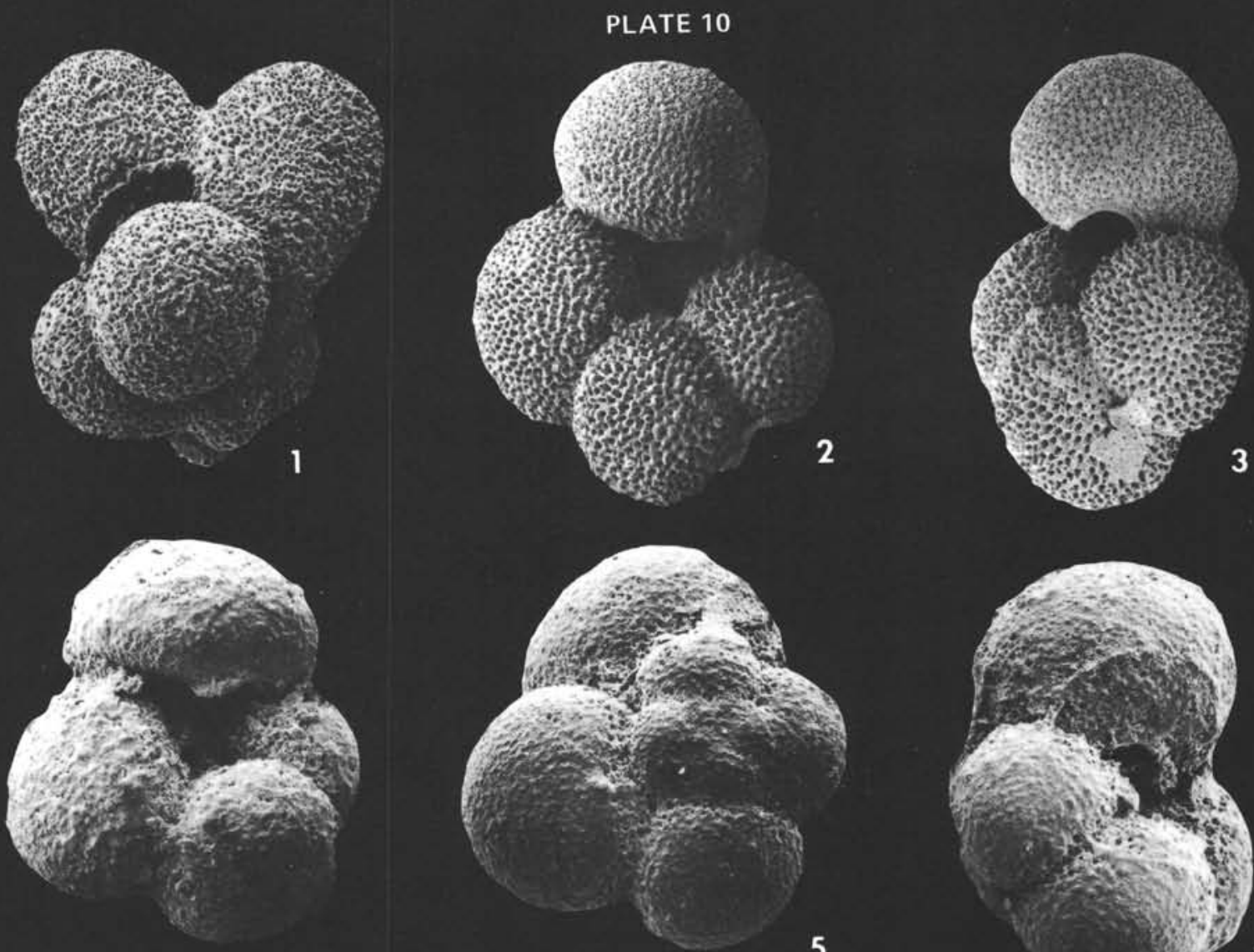

4
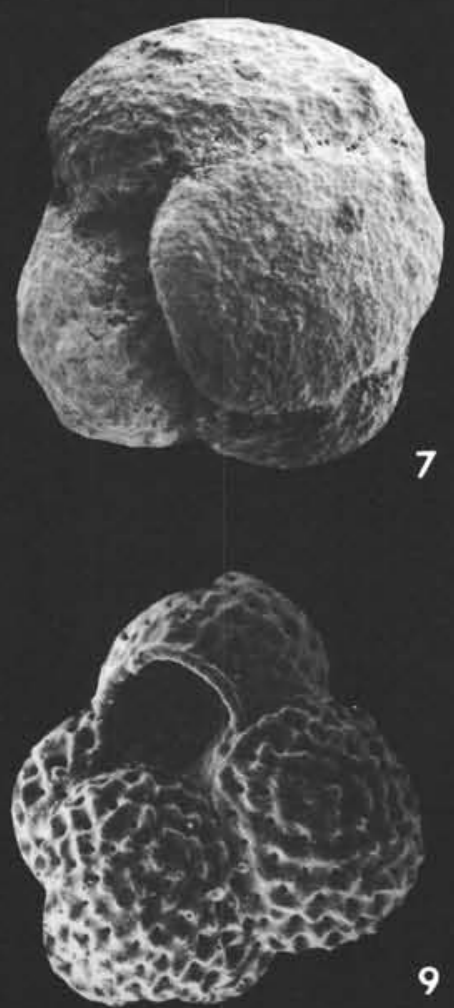

5

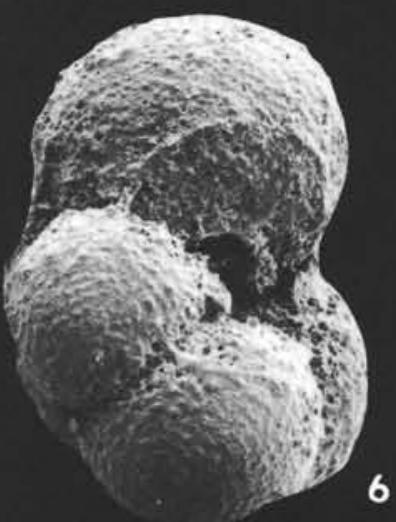

8 


\section{PLATE 11}

Figures 1-3 Globigerina sabina Luterbacher and Premoli Silva. Site 199, Core 10, Section 2; "Globigerina" eugubina Zone.

1. Umbilical view, $\times 400$.

2. Spiral view, $X 400$.

3. Side view, $\times 400$.

Figures 4-6 Globigerina taroubaensis Bronnimann. Site 200A, Core 2, core catcher; Globorotalia formosa formosa Zone; early Eocene.

4. Umbilical view, $X 175$.

5. Spiral view, $\times 165$.

6. Side view, $\times 190$.

Figures 7-9 Globigerina umbrica Luterbacher and Premoli Silva. Site 199, Core 10, Section 2; "Globigerina" eugubina Zone.

7. Umbilical view, $\times 540$.

8. Spiral view, $\times 560$.

9. Side view, $\times 500$.

Figures 10-12 Globigerina velascoensis Cushman. Site 199, Core 8, Section $1(107 \mathrm{~cm})$; Globorotalia velascoensis Zone; late Paleocene.

10. Umbilical view, $X 145$.

11. Spiral view, $X 145$.

12. Side view, $X 155$. 
PLATE 11.
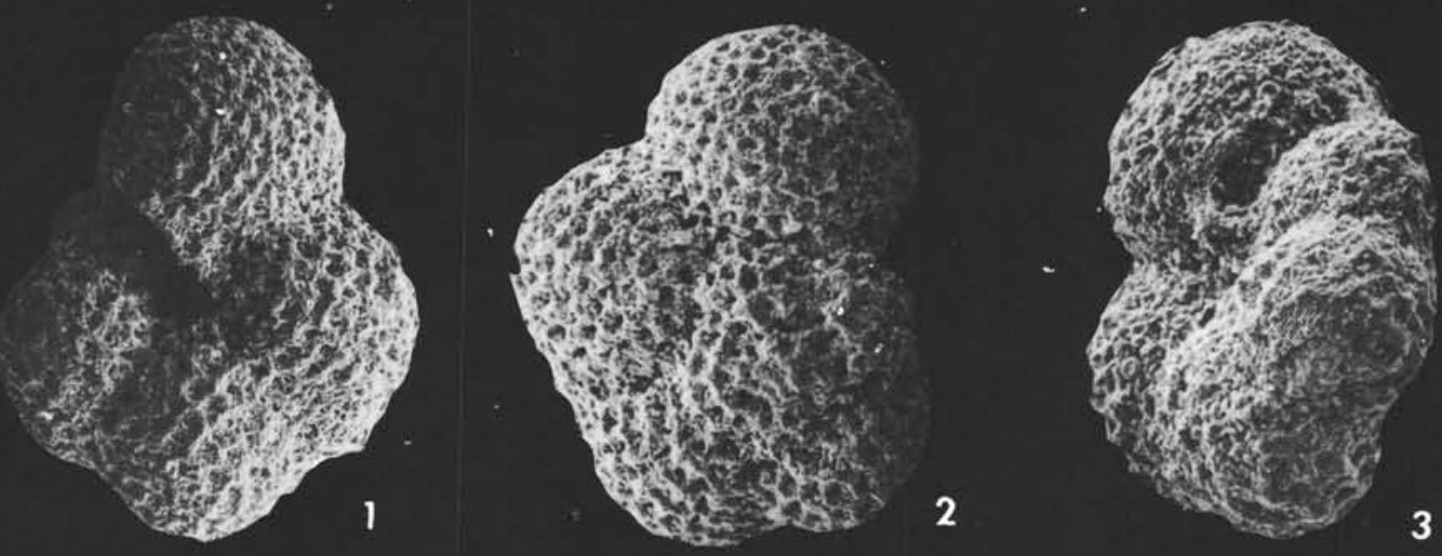

垂
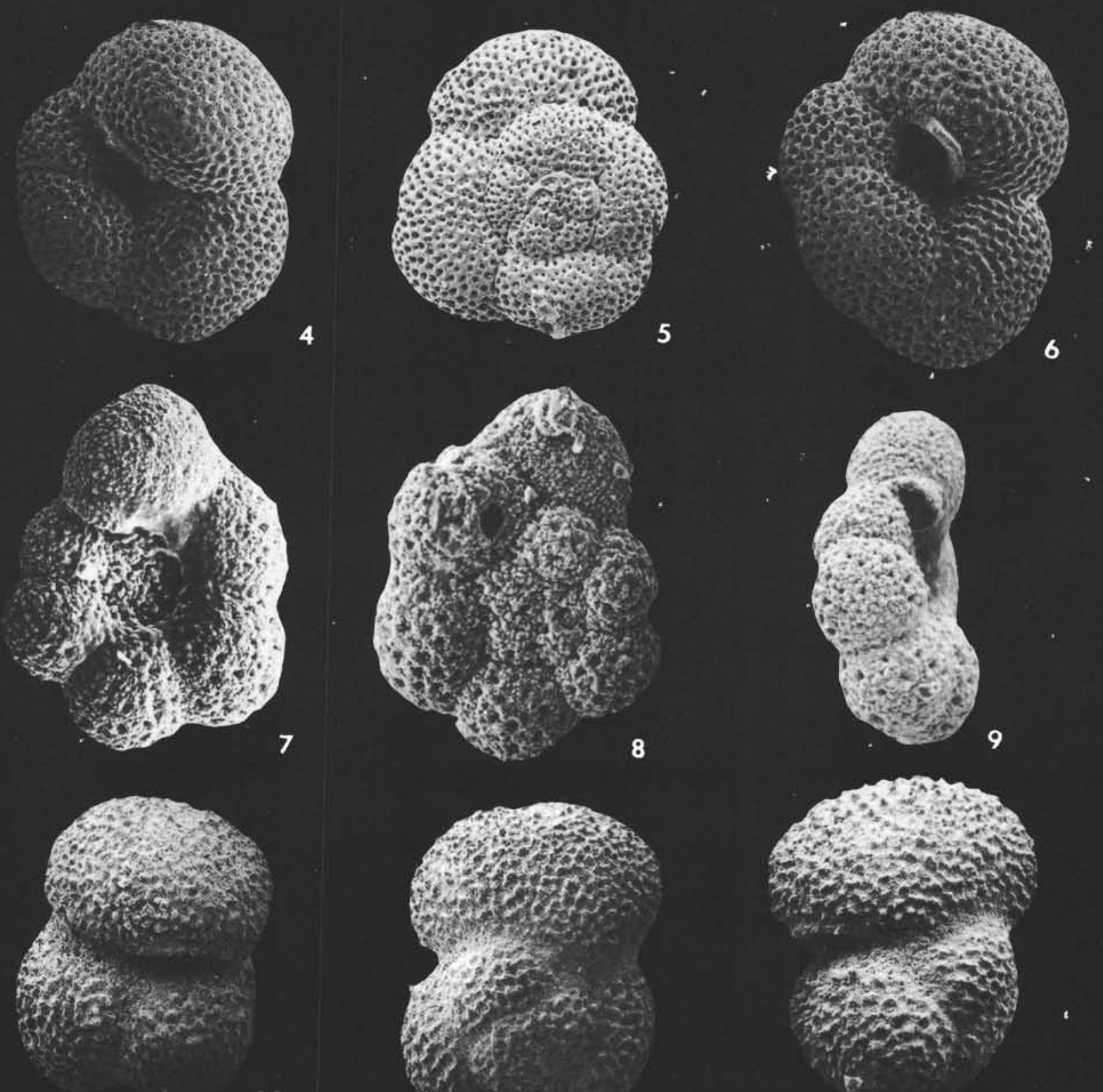


\section{PLATE 12}

Figures 1-2 Globigerina venezuelana Hedburg. Site 200, Core 4, Section 3; Globorotalia tumida-Sphaeroidinellopsis subdehiscens paenodehiscens Zone; early Pliocene.

1. Umbilical view, $\times 120$.

2. Spiral view, $X 120$.

Figure 3 Globigerinatella insueta Cushman and Stainforth; $\times 120$, Site 200, Core 9, Section 3; Globigerinoides sicanus-Globigerinatella insueta Zone; early Miocene.

Figures 4-5 Globigerinatheca barri Bronnimann. Figure 4, X105; Figure $5, \times 105$. Site 202, Core 2, core catcher; Orbulinoides beckmanni Zone; middle Eocene.

Figure 6

Globigerinita glutinata (Egger); Umbilical view, $\times 175$. Site 200, Core 6, core catcher; Globorotalia acostaensis-Globorotalia merotumida Zone; late Miocene.

Figures 7-8 Globigerinita incrusta Akers. Site 200, Core 10, core catcher; Globigerinatella insueta-Globigerinita dissimilis Zone; early Miocene.

7. Umbilical view, $\times 210$.

8. Spiral view, $\times 200$.

Figure 9 Globigerinita naparimaensis Bronnimann; Umbilical view, X155. Site 200, Core 6, core catcher; Globorotalia acostaensis-Globorotalia merotumida Zone; late Miocene.

Figures 10-11 Globigerinita aff. stainforthi (Bolli, Loeblich and Tappan). Site 200, Core 10, core catcher (hard limestone); Globigerinatella insueta-Globigerinita dissimilis Zone; early Miocene.

10. Umbilical view, $X 185$.

11. Spiral view, $X 185$. 


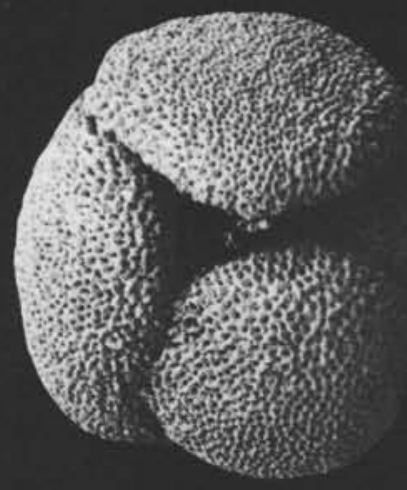

PLATE 12
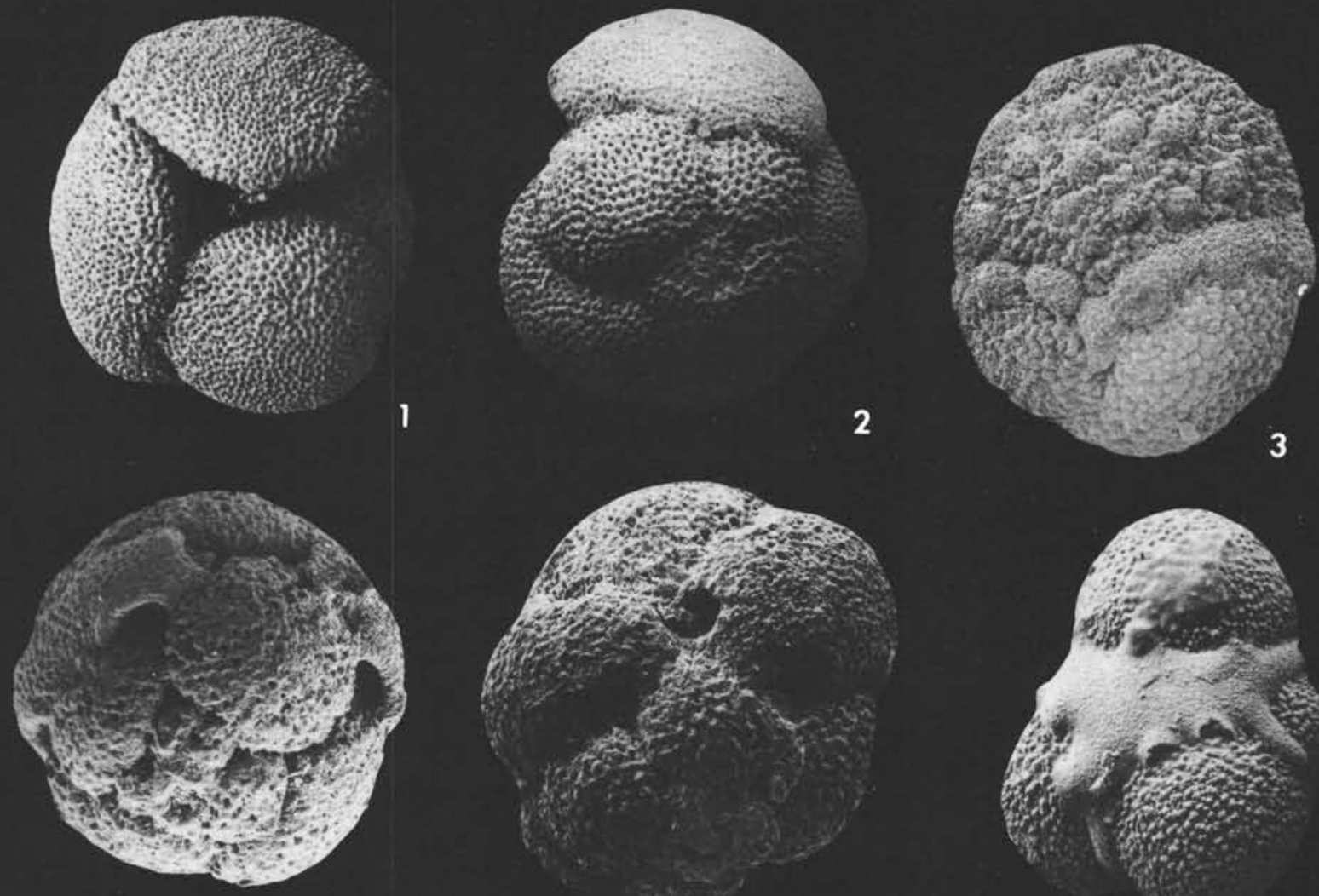

5

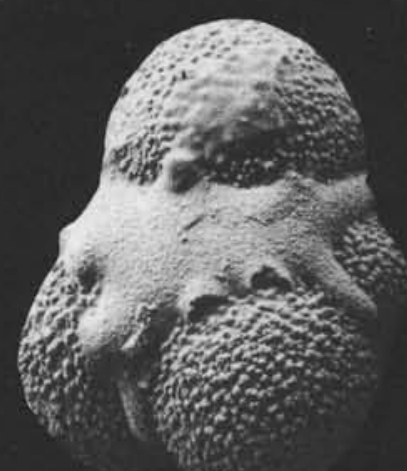

4
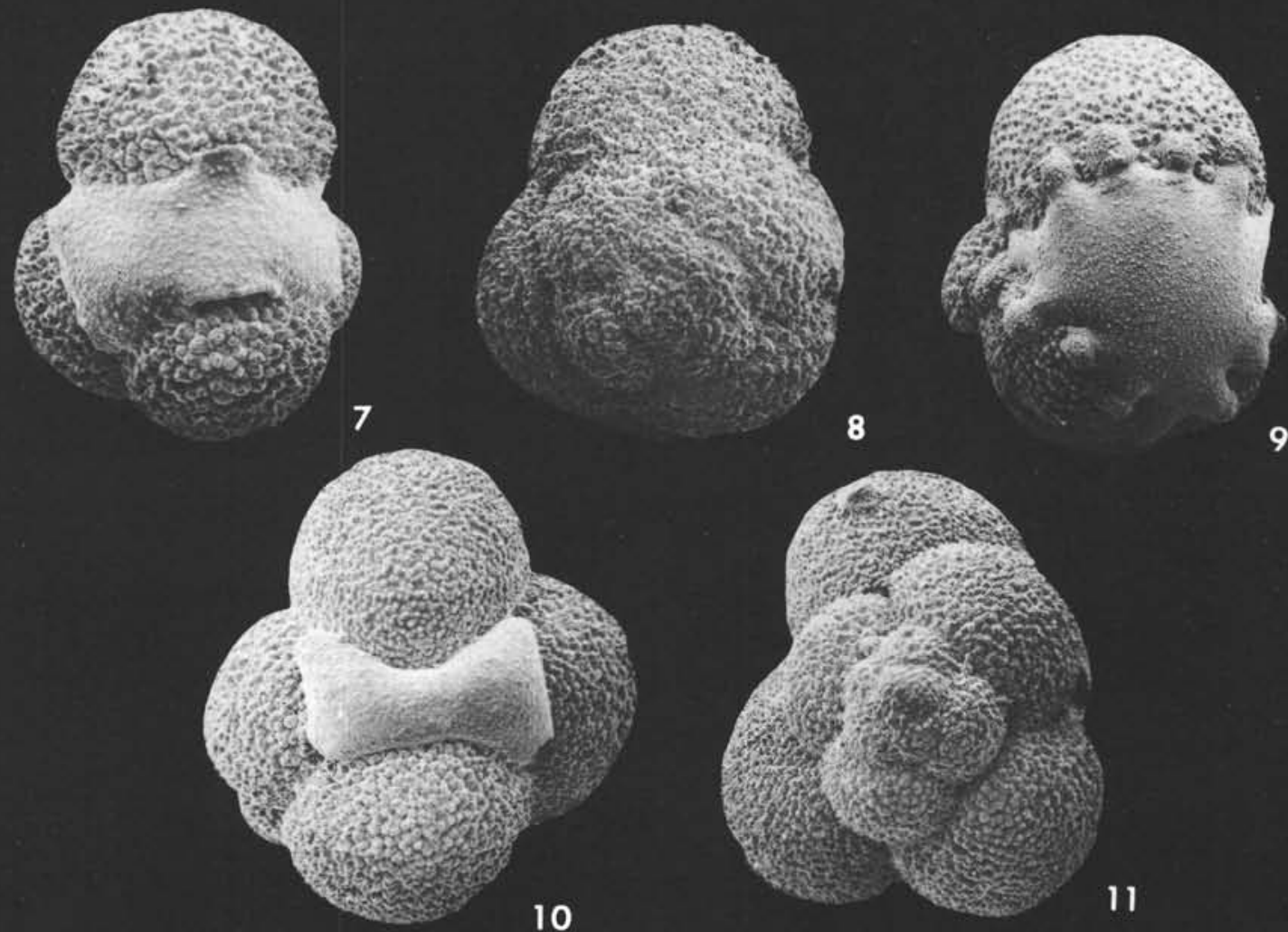

8 


\section{PLATE 13}

Figures 1-2 Globigerinoides adriatica (Fornasini). Site 200, Core 6, core catcher; Globorotalia acostaensis-Globorotalia merotumida Zone; late Miocene.

1. Umbilical view, $\times 110$.

2. Spiral view, $X 110$.

Figures 3-4 Globigerinoides bollii Blow. Site 200, Core 3, Section 2; Globorotalia multicamerata-Pulleniatina obliquiloculata Zone; Pliocene.

3. Umbilical view, $\times 170$.

4. Spiral view, $X 170$.

Figures 5-6 Globigerinoides conglobatus (Brady). Site 200, Core 3 , core catcher; Sphaeroidinella dehiscensGloboquadrina altispira Zone; Pliocene.

5. Umbilical view, 70 .

6. Spiral view, 70 .

Figures 7-8 Globigerinoides conglobatus canimarensis Bermudez. Site 200, Core 6, core catcher; Globorotalia acostaensis-Globorotalia merotumida Zone; late Miocene.

7. Umbilical view, $\times 70$.

8. Spiral view, $\times 68$.

Figure 9 Globigerinoides diminutus Bolli; Umbilical view, $\times 145$. Site 200, Core 9, Section 3; Globigerinoides sicanus-Globigerinatella insueta Zone; early Miocene.

Figures 10-12 Globigerinoides fistulosus (Schubert). Site 200, Core 2, core catcher; Globorotalia tosaensis Zone; upper Pliocene.

10. Umbilical view, $X 46$.

11. Umbilical view, $X 34$.

12. Spiral view, $X 37$; 


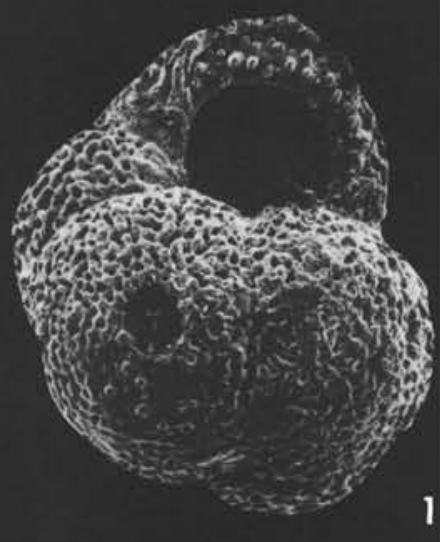

Plate 13
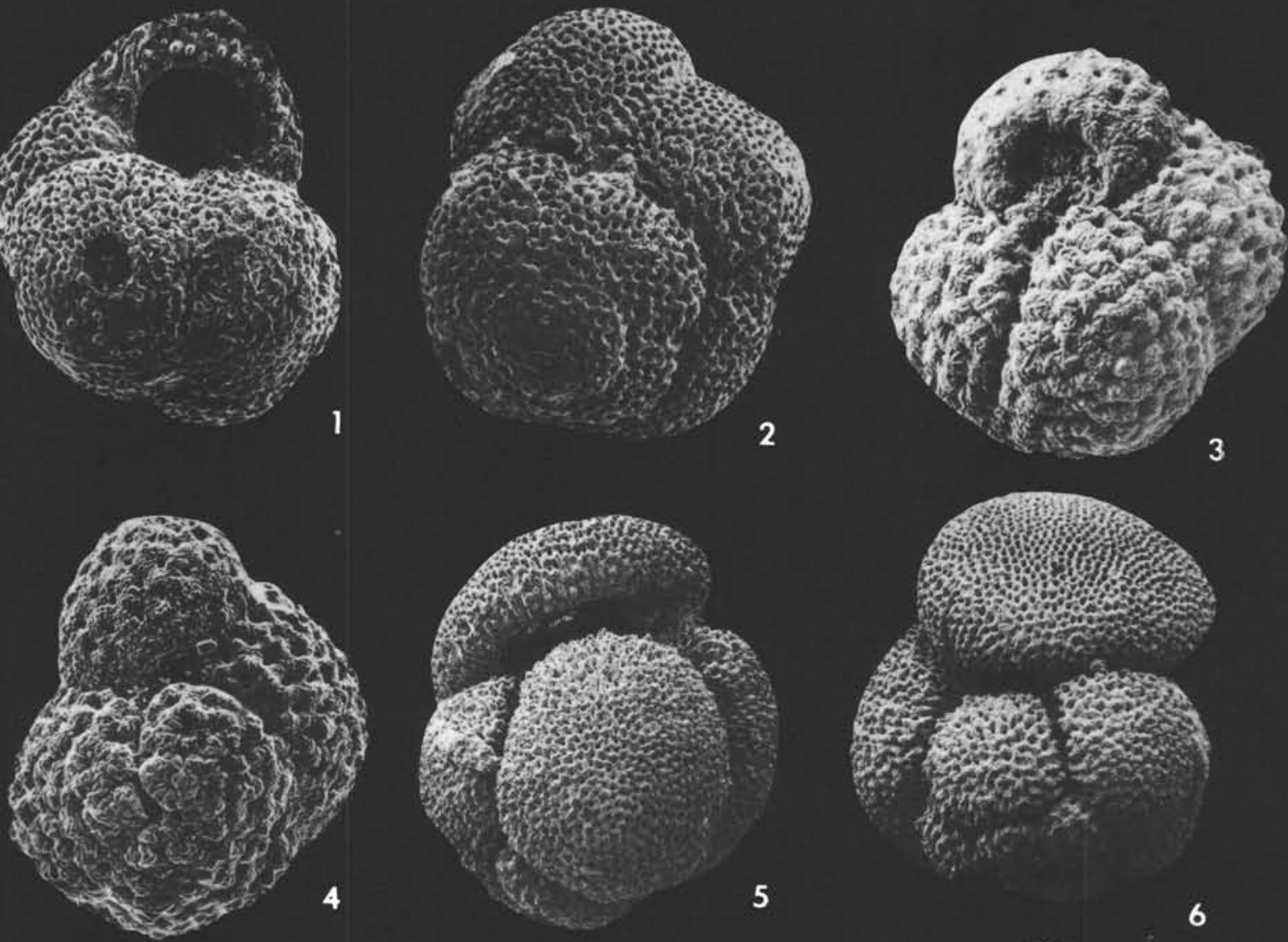

6
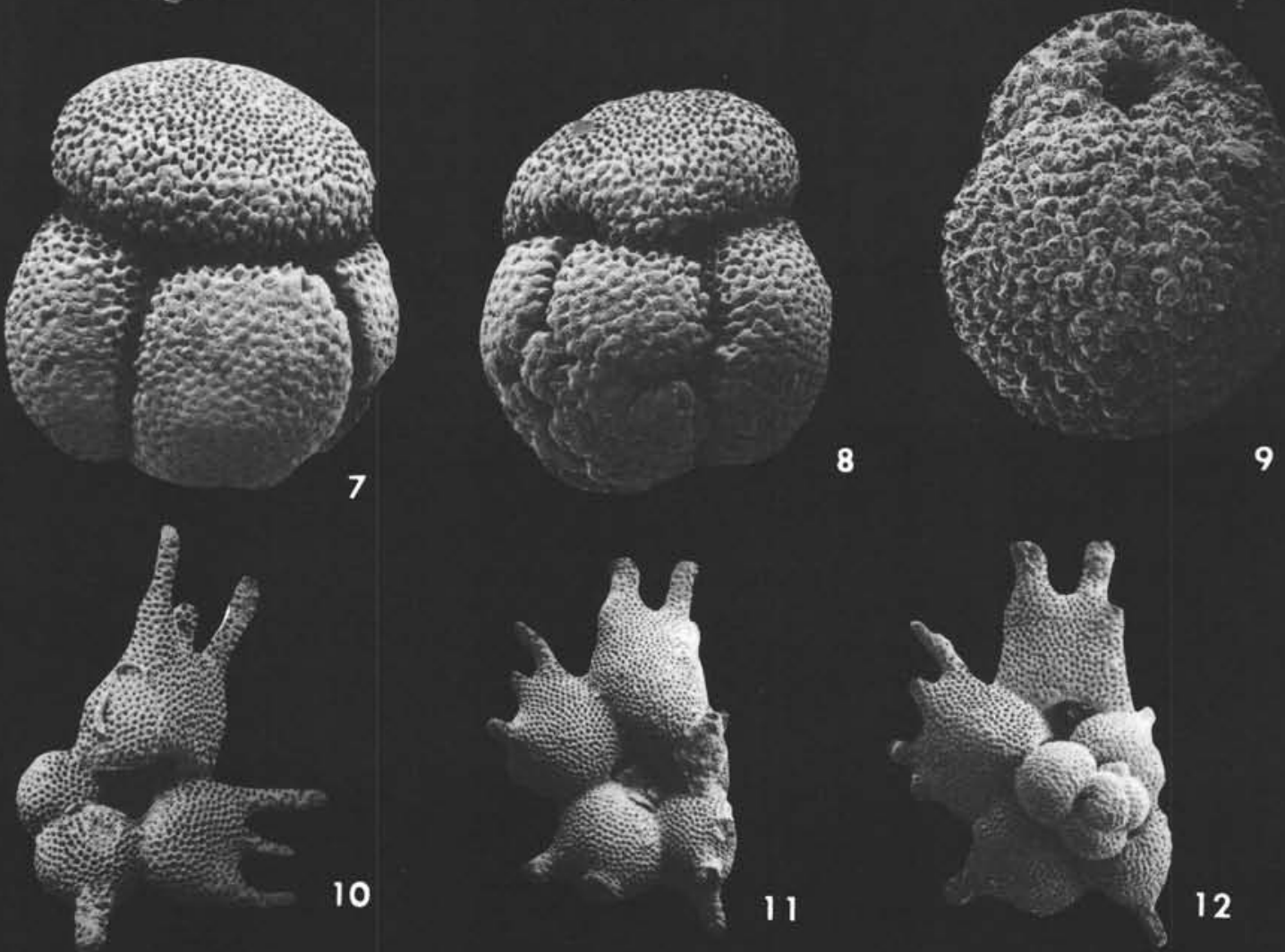

12 


\section{PLATE 14}

Figures 1-2 Globigerinoides mitra Todd. Site 200, Core 9, core catcher; Globigerinoides sicanus-Globigerinatella insueta Zone; early Miocene.
1. Umbilical view, $\times 85$.
2. Spiral view, $\times 80$.

Figures 3-4

Globigerinoides obliquus extremus Bolli and Bermudez. Site 200, Core 3, Section 2; Globorotalia multicamerata-Pulleniatina obliquiloculata Zone; Pliocene.

3. Umbilical view, $\times 135$.

4. Spiral view, $X 130$.

Figures 5-6 Globigerinoides obliquus obliquus Bolli. Site 200, Core 7, core catcher; N15-N16 of Blow; late Miocene.

5. Umbilical view, $X 130$.

6. Spiral view, $X 135$.

Figure $7 \quad$ Globigerinoides pyramidalis van den Broeck; Umbilical view X90. Site 200, Core 2, Section 2; Globorotalia tosaensis Zone; upper Pliocene.

Figures 8-9 Globigerinoides ruber d'Orbigny. Site 200, Core 1, Section 1, Globorotalia truncatulinoides Zone; Pleistocene.

8. Umbilical view, $\times 125$.

9. Spiral view, $\times 125$.

Figures 10-12 Globigerinoides sacculifer (Brady). Site 200, Core 3, core catcher, Sphaeroidinella dehiscens-Globoquadrina altispira Zone; Pliocene.

10. Umbilical view, $\times 57$.

11. Umbilical view, $X 55$.

12. Spiral view, $X 60$. 


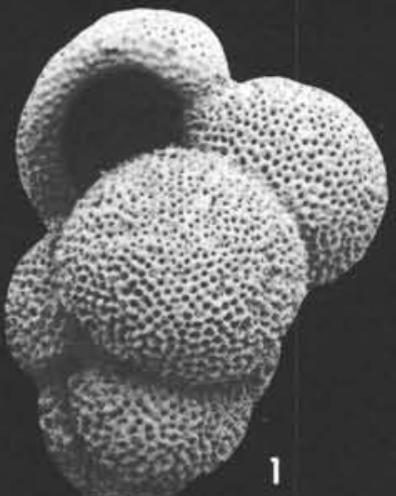

\section{PLATE 14}
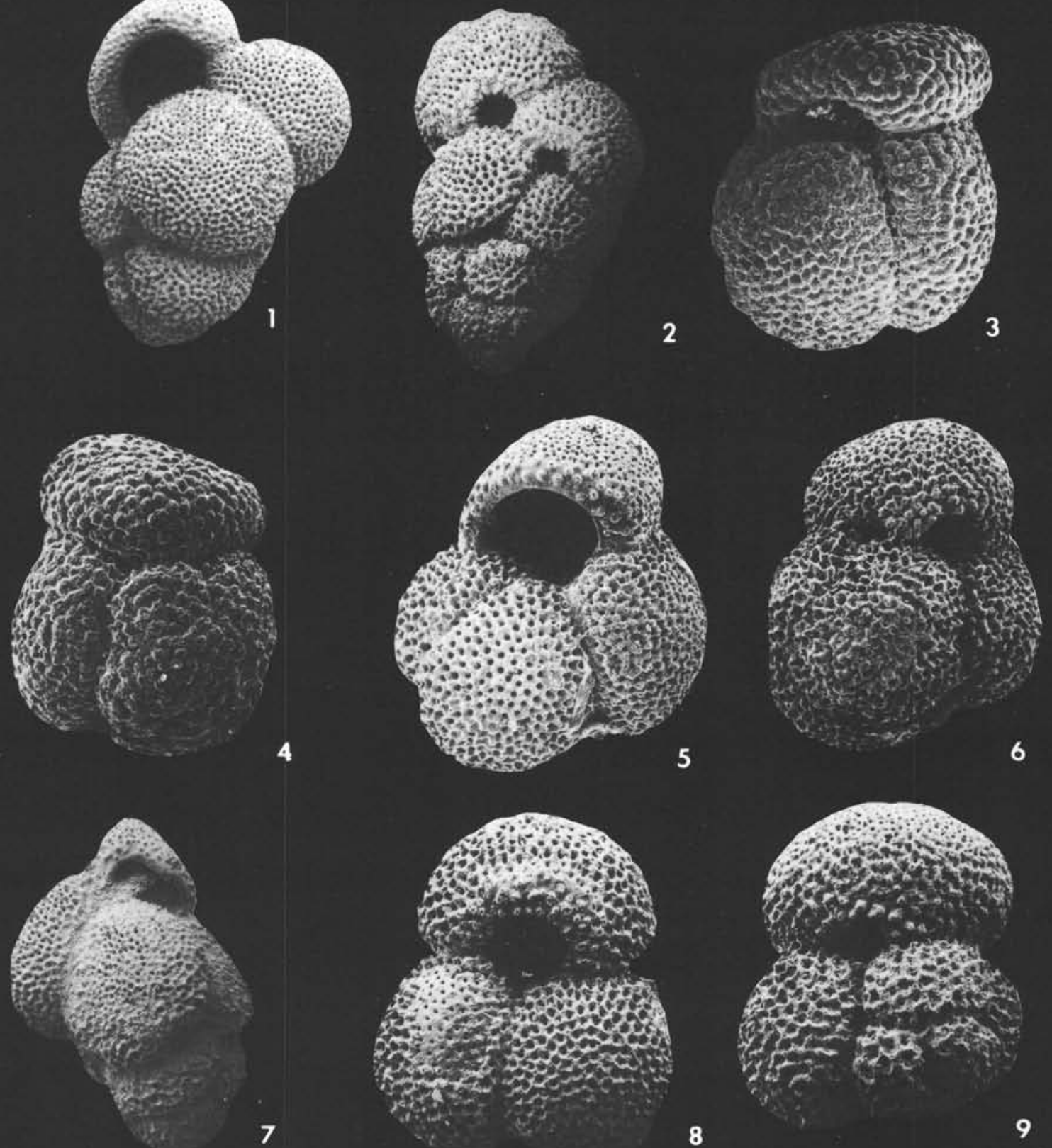

8
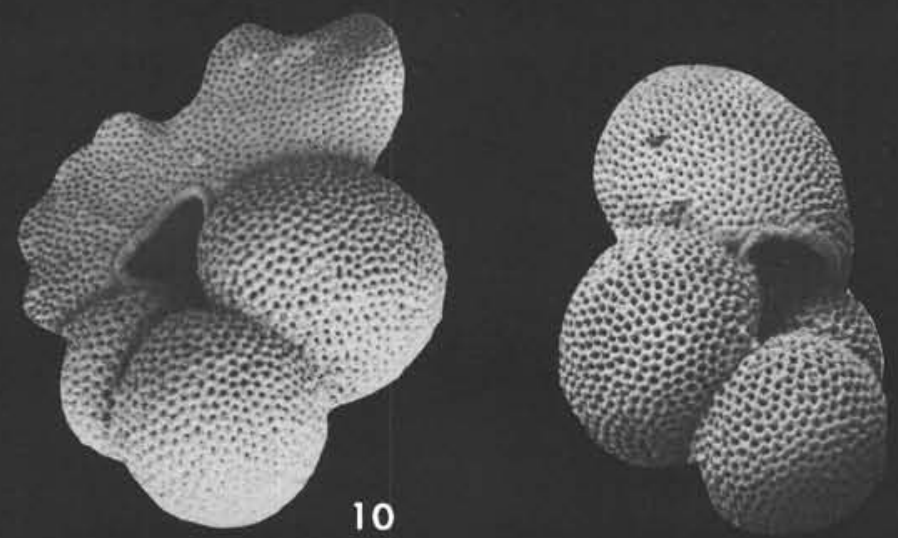

11

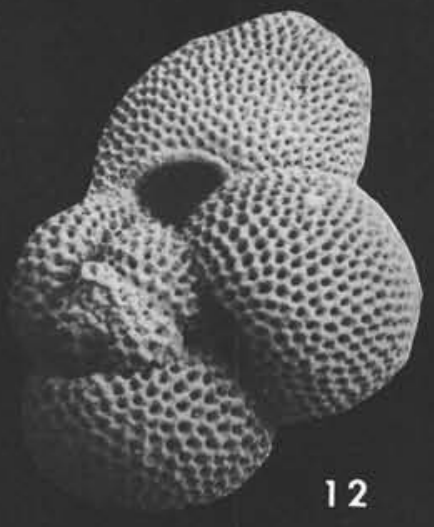




\section{PLATE 15}

Figures 1-2 Globigerinoides sicanus de Stephani. Site 200, Core 9, core catcher; Globigerinoides sicanus-Globigerinatella insueta Zone; early Miocene.

1. Umbilical view, $X 81$.

2. Spiral view, $\times 79$.

Figures 3-5 Globigerinoides subquadratus Bronnimann. Site 200, Core 10, core catcher (Hard limestone); Globigerinatella insueta-Globigerinita dissimilis Zone; early Miocene.

3. Umbilical view, $\times 130$.

4. Spiral view, $\times 185$.

5. Side view, $X 118$.

Figures 6.9 Globigerinoides trilobus (Reuss). Site 200, Core 10, core catcher (Hard limestone); Globigerinatella insueta-Globigerinita dissimilis Zone; early Miocene.

6. Umbilical view, $\times 130$.

7. Spiral view, $X 130$.

8. Umbilical view, $X 120$.

9. Spiral view, $X 120$.

Figures 10-12 Globoquadrina altispira (Cushman and Jarvis). Site 200, Core 10, core catcher (Hard limestone); Globigerinatella insueta-Globigerinita dissimilis Zone; early Miocene.

10. Umbilical view, $\times 82$.

11. Spiral view, $\times 82$.

12. Side view, $\times 82$. 
PLATE 15
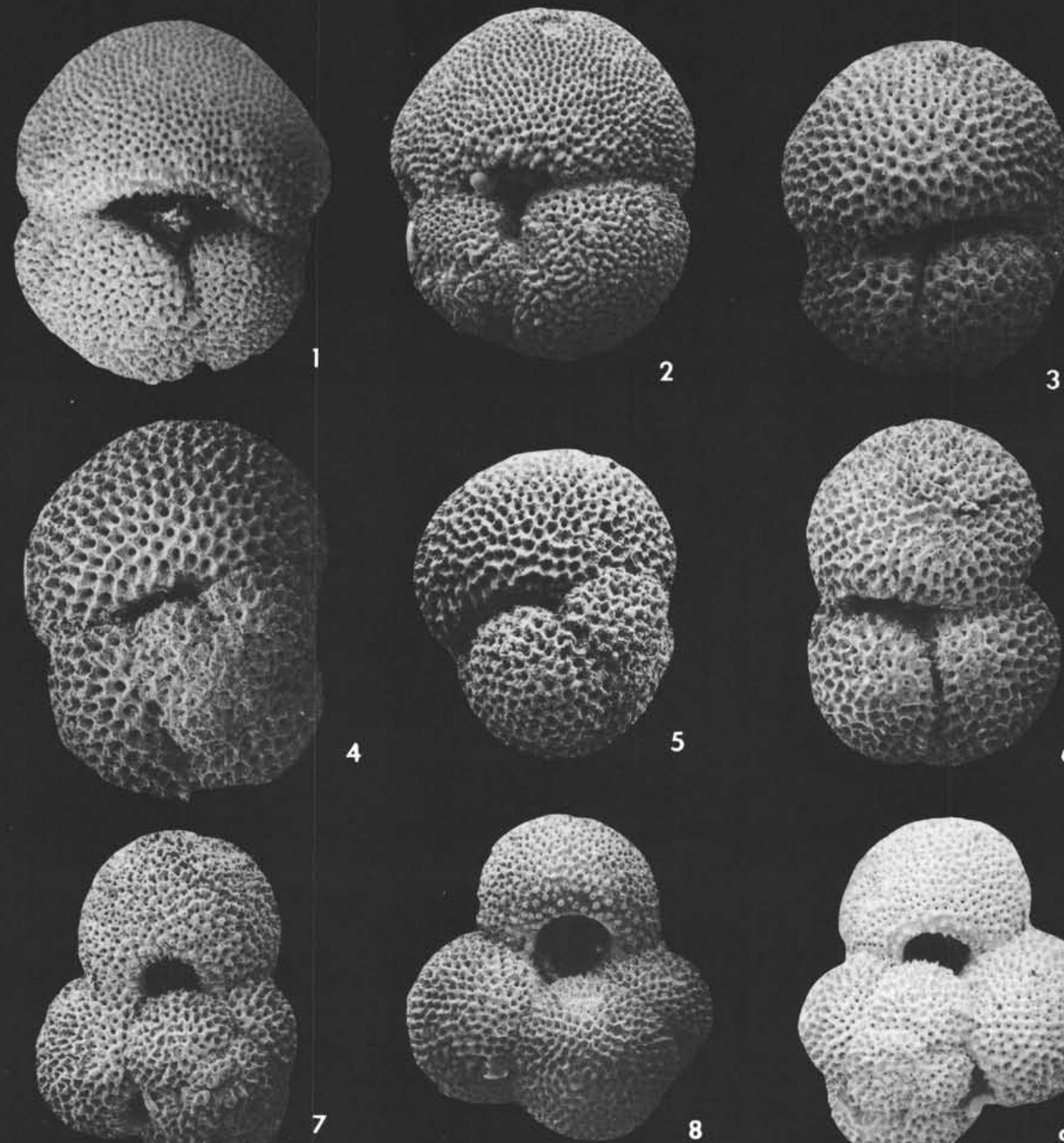

4
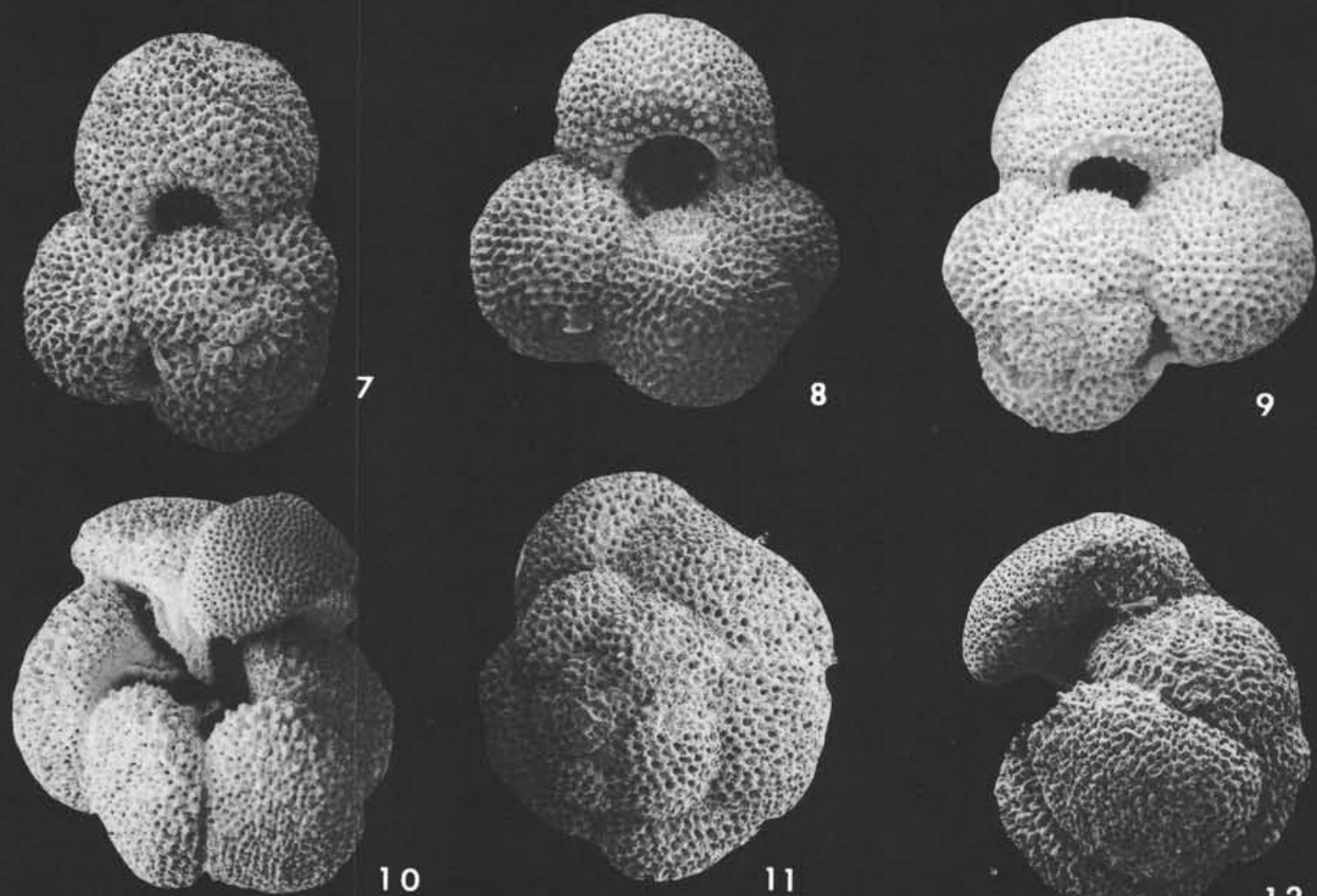
PLATE 16

Figures 1-3 Globoquadrina baroemoenensis (LeRoy). Site 200, Core 10, core catcher (Hard limestone); Globigerinatella insueta-Globigerinita dissimilis Zone; early Miocene.

1. Umbilical view, $X 88$.

2. Spiral view, $\times 85$.

3. Side view, $\times 82$.

Figures 4-6 Globoquadrina dehiscens (Chapman, Parr and Collins). Site 200, Core 7, core catcher; N15-N16 of Blow; late Miocene.

4. Umbilical view, $\times 120$.

5. Spiral view, $X 125$.

6. Side view, $\times 120$.

Figures 7-9 Globoquadrina langhiana Cita and Gelati. Site 200, Core 10, core catcher (soft material); Globigerinoides sicanus-Globigerinatella insueta Zone; early Miocene.

7. Umbilical view, $\times 120$.

8. Spiral view, $X 140$.

9. Side view, $\times 135$.

Figures 10-12 Globoquadrina larmeui obesa Akers. Site 200, Core 9, Section 3; Globigerinoides sicanus-Globigerinatella insueta Zone; early Miocene.

10. Umbilical view, $\times 76$.

11. Spiral view, $\times 76$.

12. Side view, $\times 79$. 


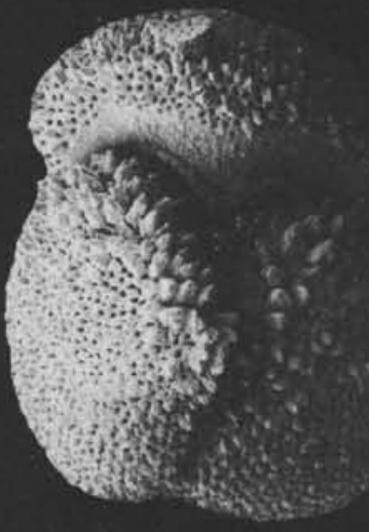

\section{PLATE 16}
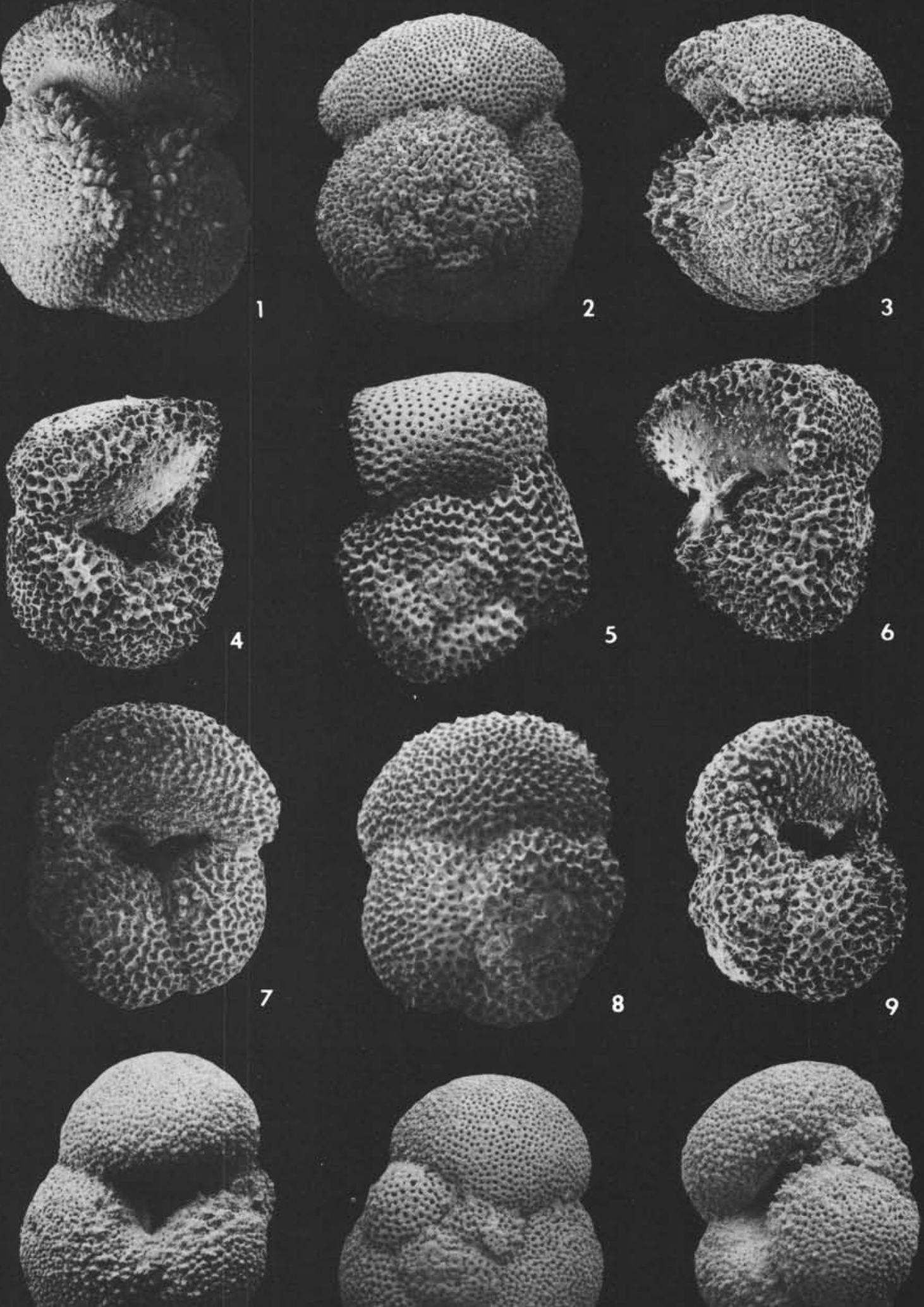


\section{PLATE 17}

Figures 1-3 Globoquadrina praedehiscens Blow and Banner. Site 200, Core 10, core catcher (Hard limestone); Globigerinatella insueta-Globigerinita dissimilis Zone; early Miocene.

1. Side view, $\times 90$.

2. Spiral view, $\times 100$.

3. Umbilical view, $\times 98$.

Figures 4-6 Globorotalia acostaensis Blow. Site 200, Core 6, core catcher; Globorotalia acostaensis-Globorotalia merotumida Zone; late Miocene.

4. Umbilical view, $\times 165$.

5. Spiral view, $X 165$.

6. Side view, $\times 150$.

Figures 7-9 Globorotalia acuta Toulmin. Site 199, Core 8, Section $1(107 \mathrm{~cm})$; Globorotalia velascoensis Zone; late Paleocene.

7. Umbilical view, $\times 100$.

8. Spiral view, $\times 95$.

9. Side view, $X 115$.

Figures 10-12 Globorotalia aequa Cushman and Renz. Site 200A, Core 2, core catcher; Globorotalia formosa formosa Zone; early Eocene.

10. Umbilical view, $X 150$.

11. Spiral view, $\times 140$.

12. Side view, $\times 150$. 


\section{PLATE 17}
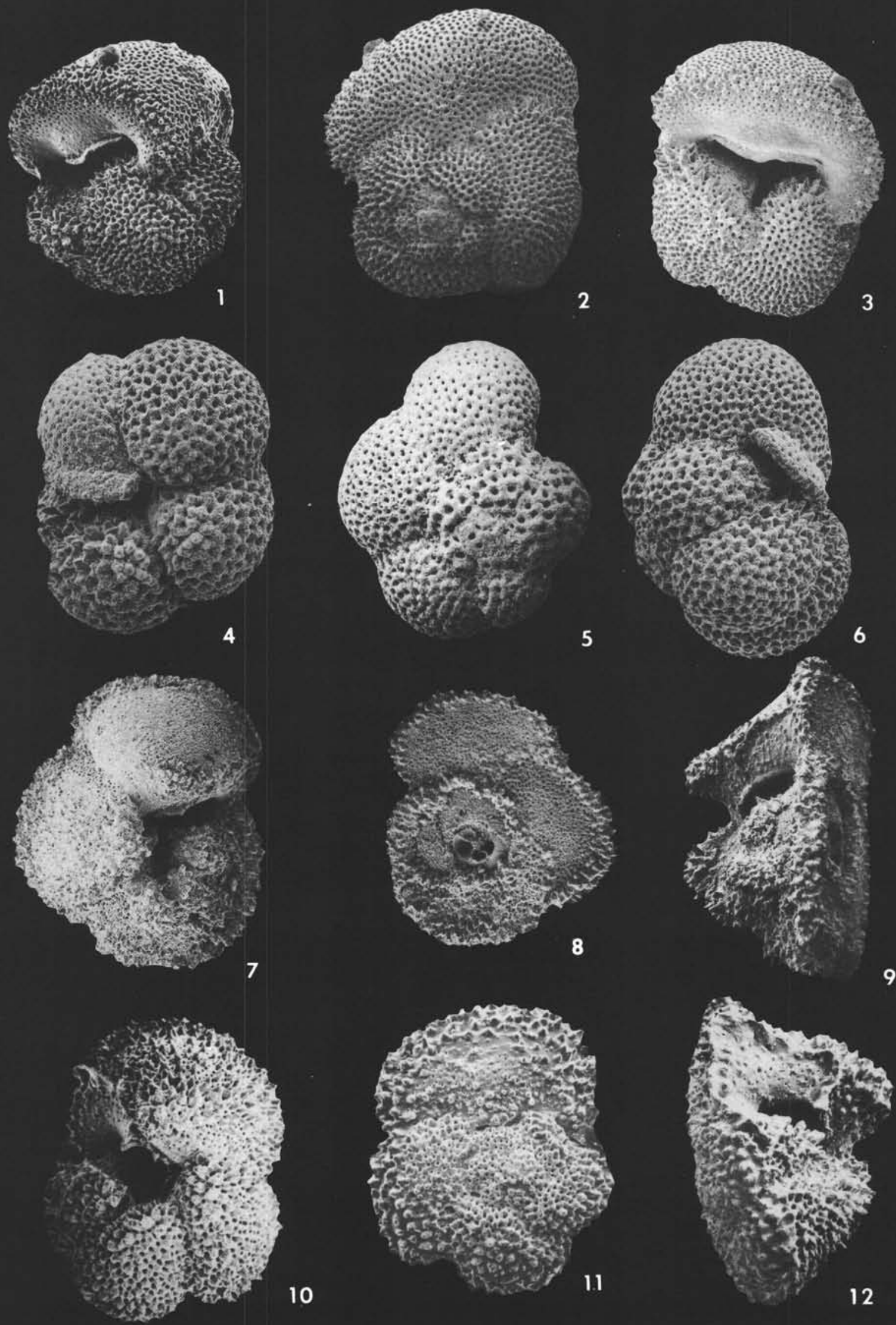


\section{PLATE 18}

Figures 1-3 Globorotalia apanthesma Loeblich and Tappan. Site 200A, Core 2, core catcher; Globorotalia formosa formosa Zone; early Eocene.

1. Umbilical view, $\times 100$.

2. Spiral view, $X 135$.

3. Side view, $X 135$.

Figures 4-6 Globorotalia aragonensis Nuttall. Site 200A, Core 2, core catcher; Globorotalia formosa formosa Zone; early Eocene.

4. Umbilical view, $\times 87$.

5. Side view, $X 98$.

6. Spiral view, $\times 82$.

Figures 7-9 Globorotalia archeomenardii Bolli. Site 200, Core 9, Section 2; Globigerinoides sicanus-Globigerinatella insueta Zone; early Miocene.

7. Umbilical view $\times 155$.

8. Spiral view, $\times 170$.

9. Side view, $\times 185$.

Figures 10-12 Globorotalia bermudezi (Bolli). Site 200, Core 9, Section 1 (top); Globigerinoides sicanus-Globigerinatella insueta Zone; early Miocene.

10. Umbilical view, $X 100$.

11. Spiral view, $X 100$.

12. Side view, $\times 100$. 


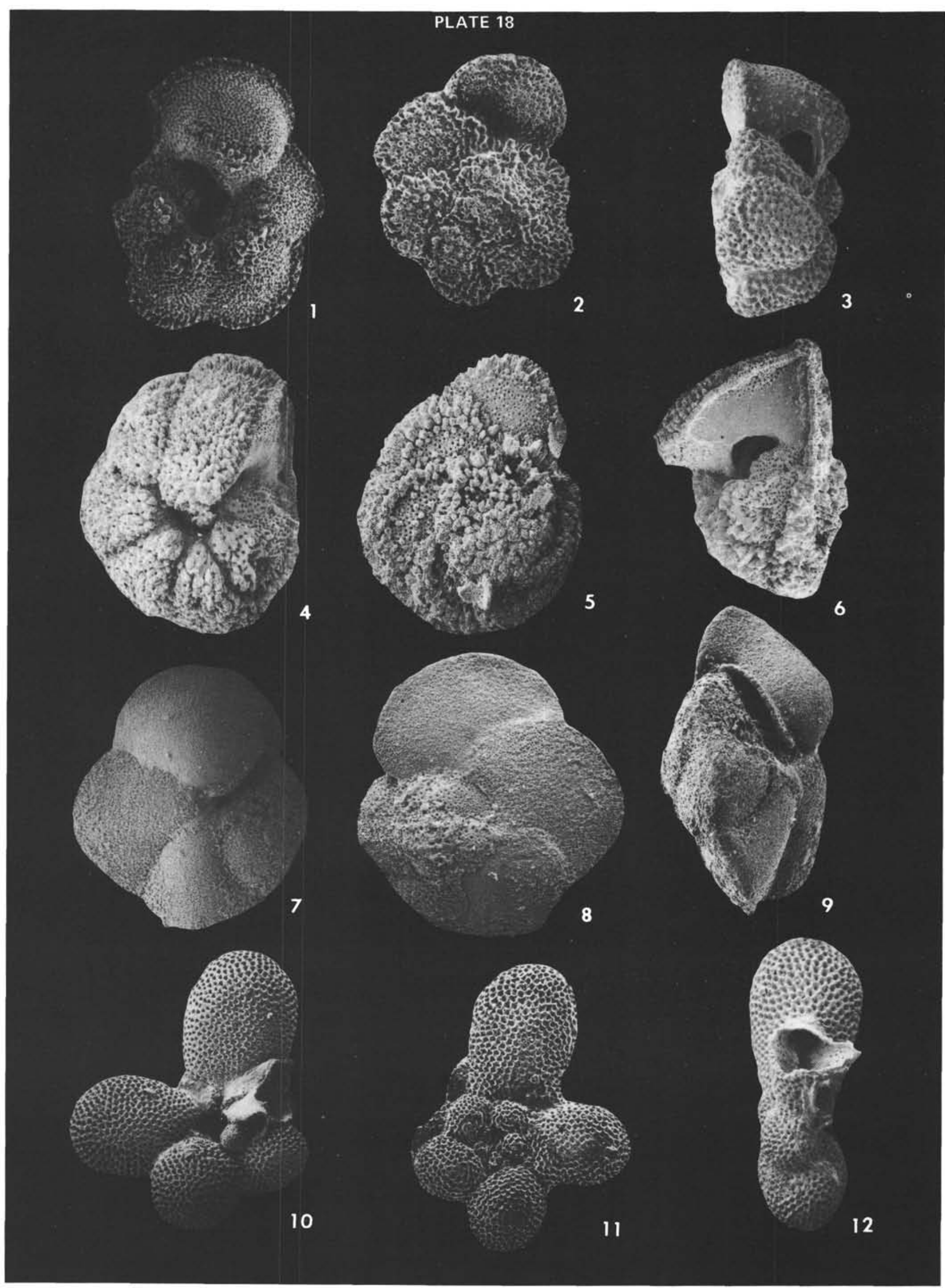


PLATE 19

Figures 1-3 Globorotalia caucasica Glaessner. Site 200A, Core 2, core catcher; Globorotalia formosa formosa Zone; early Eocene.

1. Umbilical view, $\times 70$.

2. Spiral view, $\times 68$.

3. Side view, $\times 70$.

Figures 4-6 Globorotalia centralis Cushman and Bermudez. Site 202, Core 2, core catcher; Orbulinoides beckmanni Zone; middle Eocene.

4. Umbilical view, $\times 100$.

5. Spiral view, $\times 71$.

6. Side view, $\times 105$.

Figures 7-9 Globorotalia aff. collactea Finlay. Site 200A, Core 2, core catcher; Globorotalia formosa formosa Zone; early Eocene.

7. Umbilical view, $\times 160$.

8. Spiral view, $\times 135$.

9. Side view, $\times 165$.

Figures 10-12 Globorotalia continuosa Blow. Site 200, Core 9, Section 3; Globigerinoides sicanus-Globigerinatella insueta Zone; early Miocene.

10. Umbilical view, $X 180$.

11. Spiral view, $\times 165$.

12. Side view, $X 185$. 

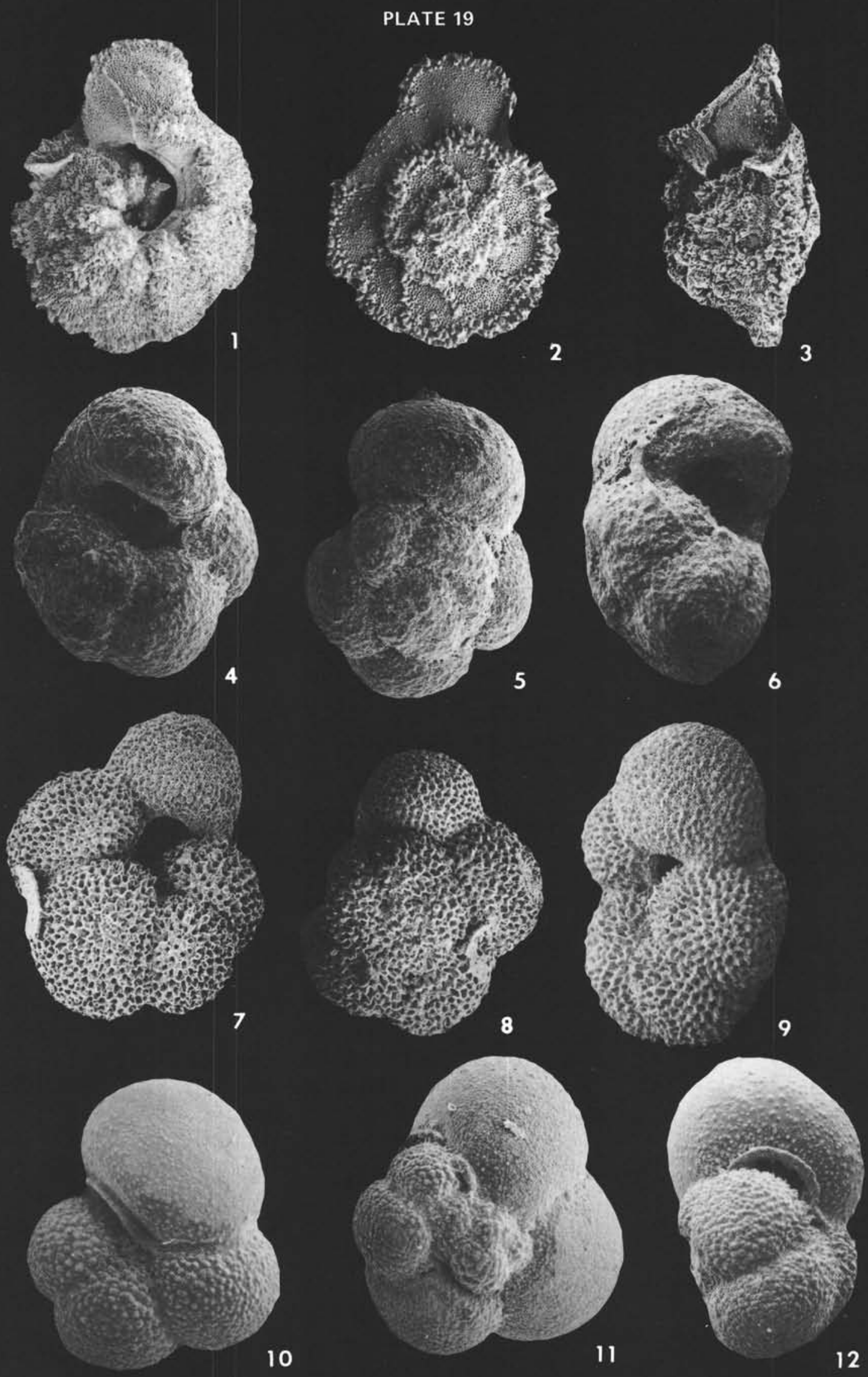


\section{PLATE 20}

Figures 1-3 Globorotalia crassaformis (Galloway and Wissler). Site 200, Core 3, core catcher; Sphaeroidinella dehiscens-Globoquadrina altispira Zone; Pliocene.

1. Umbilical view, $X 100$.

2. Spiral view, $X 100$.

3. Side view, $\times 90$.

Figures 4-6 Globorotalia cultrata (d'Orbigny). Site 200, Core 6, core catcher; Globorotalia acostaensis-Globorotalia merotumida Zone; late Miocene.

4. Umbilical view, $\times 70$

5. Spiral view, $X 65$

6. Side view, $X 80$.

Figures 7-9 Globorotalia dutertrei d'Orbigny. Site 200, Core 1, Section 1; Globorotalia truncatulinoides Zone; Pleistocene.

7. Umbilical view, $\times 105$.

8. Spiral view, $\times 105$.

9. Side view, $\times 80$.

Figures 10-11 Globorotalia fimbriata (Brady). Site 200, Core 1, Section 1; Globorotalia truncatulinoides Zone; Pleistocene.

10. Umbilical view, $\times 57$.

11. Spiral view, $\times 57$. 


\section{PLATE 20}
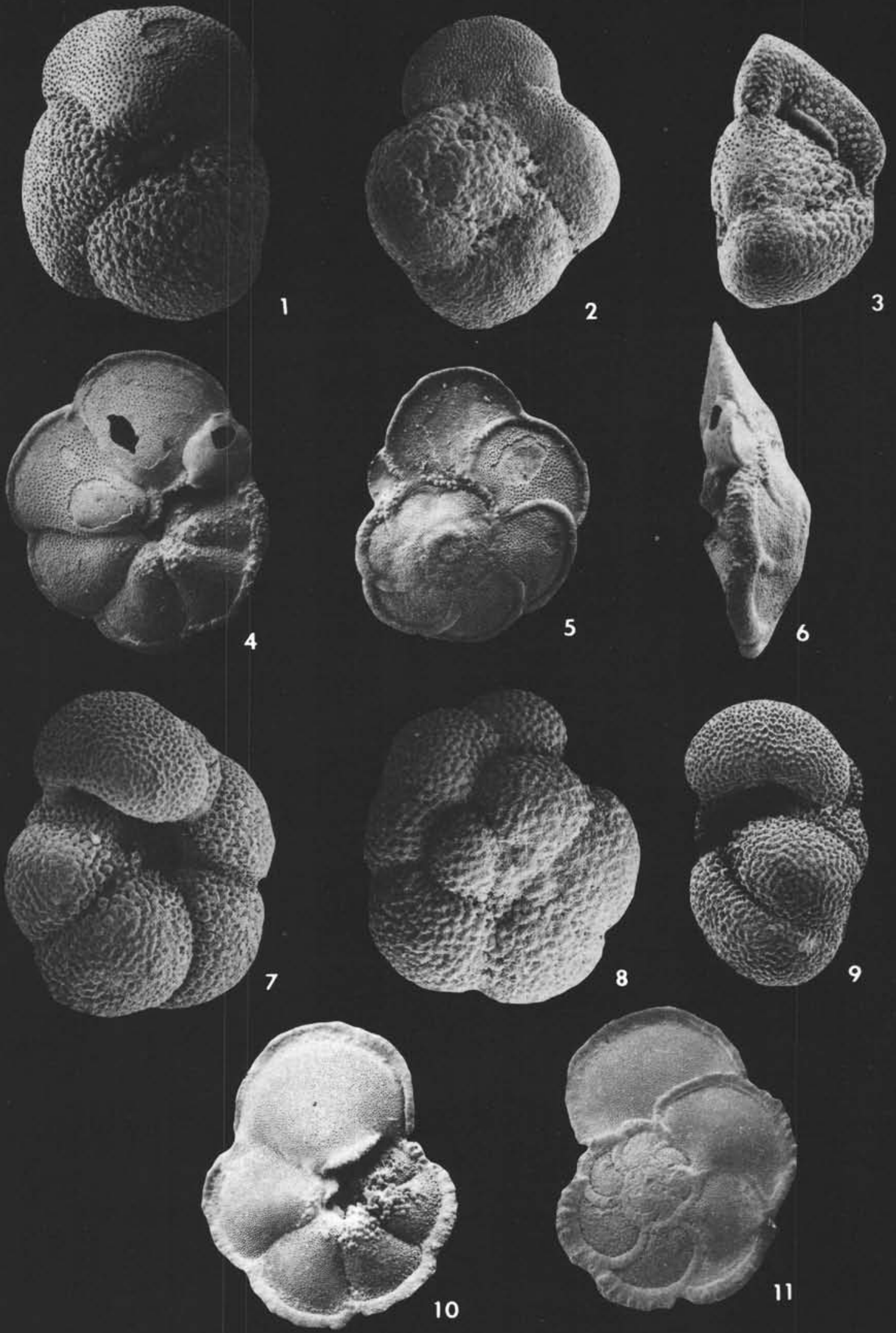
PLATE 21

Figures 1-3 Globorotalia flexuosa Koch. Site 200, Core 3, Section 2; Globorotalia multicamerata-Pulleniatina obliquiloculata Zone; Pliocene.

1. Umbilical view, $\times 50$.

2. Spiral view, $\times 50$.

3. Edge view, $\times 50$.

Figures 4-6 Globorotalia formosa formosa Bolli. Site 200A, Core 2, core catcher; Globorotalia formosa formosa Zone; early Eocene.

4. Umbilical view, $\times 100$.

5. Spiral view, $X 100$.

6. Edge view, $\times 112$.

Figures 7-9 Globorotalia formosa gracilis Bolli. Site 200A, Core 2, core catcher; Globorotalia formosa formosa Zone; early Eocene.

7. Umbilical view, $X 120$.

8. Spiral view, $\times 110$.

9. Side view, $\times 125$

Figures 10-12 Globorotalia n. sp. Site 200, Core 9, Section 1; Orbulina suturalis Zone; middle Miocene.

10. Umbilical view, $X 130$.

11. Spiral view, $\times 115$.

12. Side view, $X 125$. 


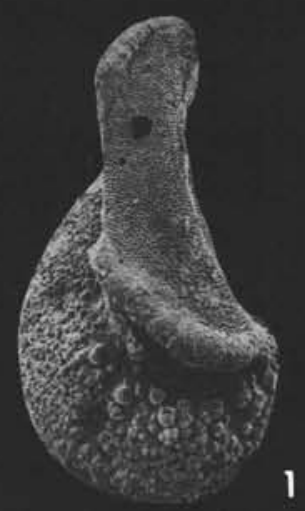

PLATE 21
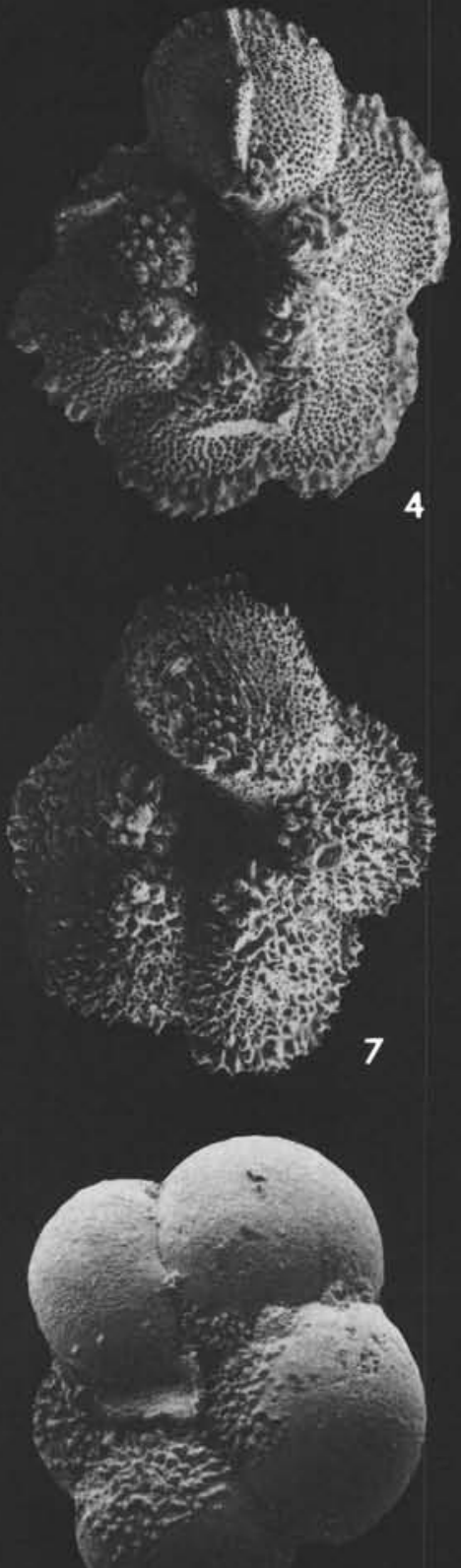

10
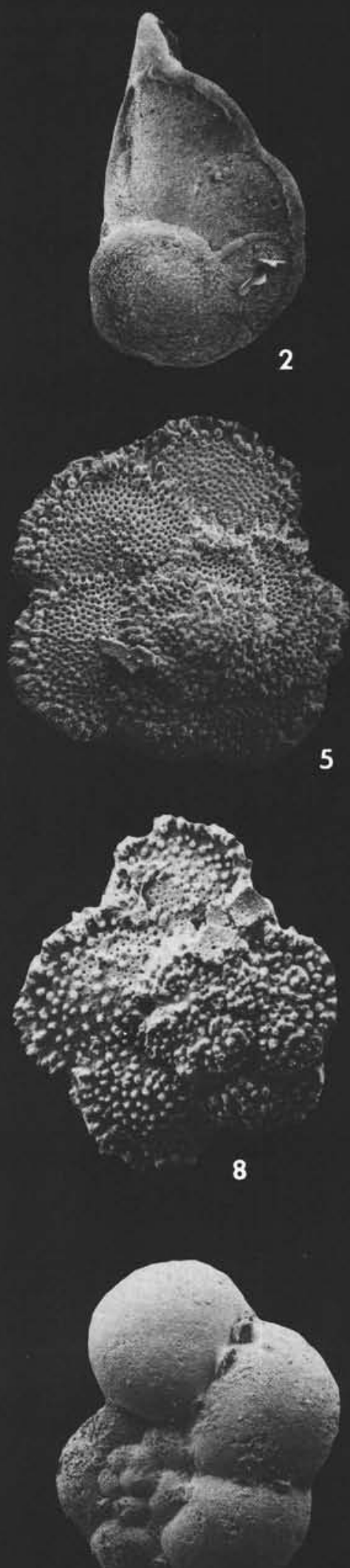

11
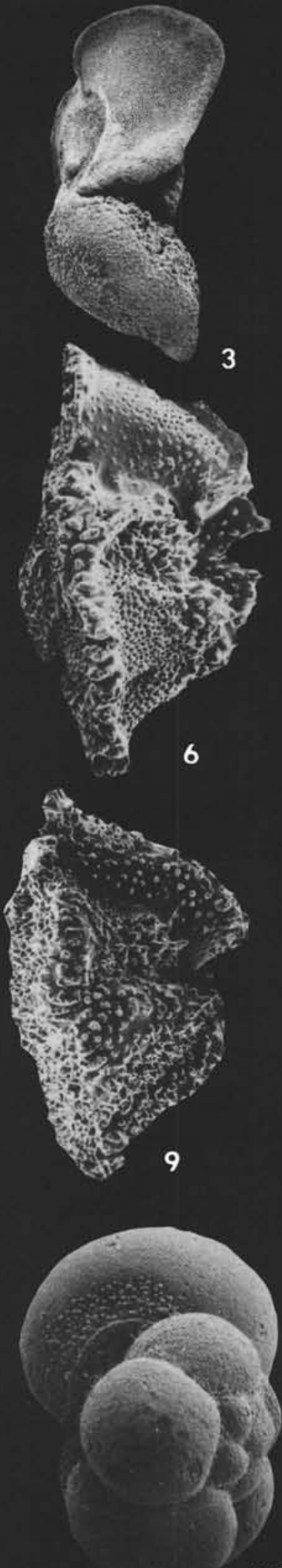

12 


\section{PLATE 22}

Figures 1-3 Globorotalia hirsuta (d'Orbigny). Site 200, Core 3, core catcher; Sphaeroidinella dehiscens-Globoquadrina altispira Zone; Pliocene.

1. Umbilical view, $\times 85$.

2. Spiral view, $\times 90$.

3. Side view, $\times 103$.

Figures 4-6 Globorotalia hispicidaris Loeblich and Tappan. Site 199, Core 8, Section 1 (107 cm); Globorotalia velascoensis Zone; late Paleocene.

4. Umbilical view, $X 105$.

5. Spiral view, $X 100$.

6. Side view, $\times 105$.

Figures 7-9 Globorotalia humerosa Takayanagi and Saito. Site 200, Core 3, Section 3; Sphaeroidinella dehiscensGloboquadrina altispira Zone; Pliocene.

7. Umbilical view, $\times 87$.

8. Spiral view, $\times 80$.

9. Side view, $\times 87$.

Figures 10-12 Globorotalia imitata Subbotina. Site 199, Core 8, Section $1(107 \mathrm{~cm})$; Globorotalia velascoensis Zone; late Paleocene.

10. Umbilical view, $X 265$.

11. Spiral view, $\times 265$.

12. Side view, $\times 265$. 

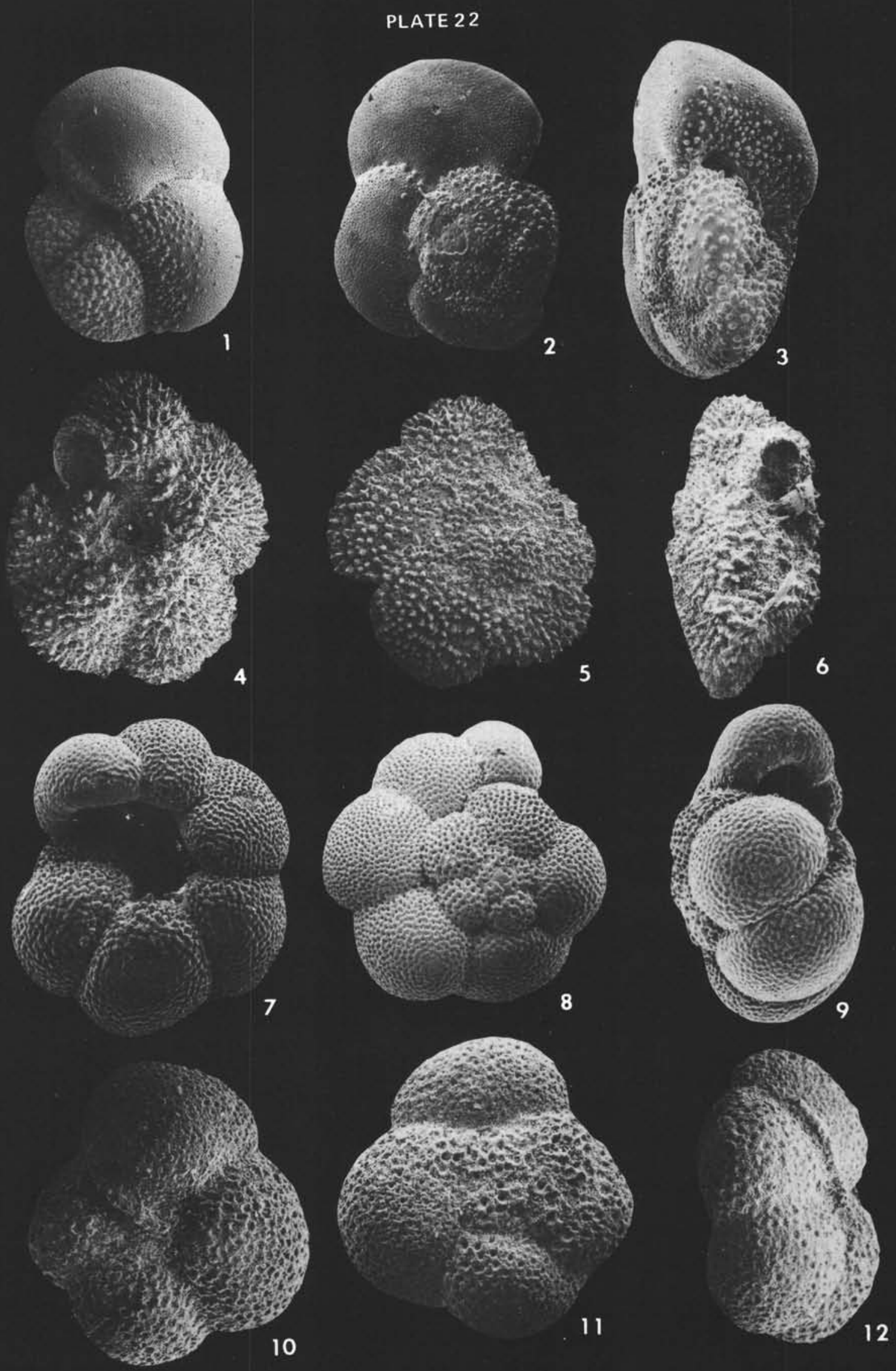


\section{PLATE 23}

Figures 1-3 Globorotalia inflata (d'Orbigny). Site 200, Core 2, core catcher; Globorotalia tosaensis Zone; late Pliocene.

1. Umbilical view, $X 95$.

2. Spiral view, $X 85$.

3. Side view, $\times 85$.

Figures 4-6 Globorotalia laevigata Bolli. Site 199, Core 10, Section 2 (37-38 cm); Globorotalia pseudomenardii Zone; late Paleocene.
4. Umbilical view, $\times 105$.
5. Spiral view, $X 112$.
6. Side view, $\times 125$.

Figures 7-9 Globorotalia lehneri Cushman and Jarvis. Site 202, Core 2, core catcher; Orbulinoides beckmanni Zone; middle Eocene.

7. Umbilical view, $\times 95$.

8. Spiral view, $X 110$.

9. Side view, $\times 100$.

Figures 10-12 Globorotalia lensiformis Subbotina. Site 200A, Core 2, core catcher; Globorotalia formosa formosa Zone; early Eocene.

10. Umbilical view, $\times 160$.

11. Spiral view, $\times 150$.

12. Side view, $X 185$. 


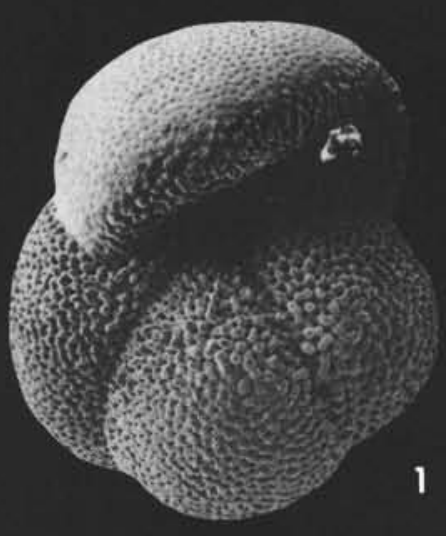

\section{PLATE 23}
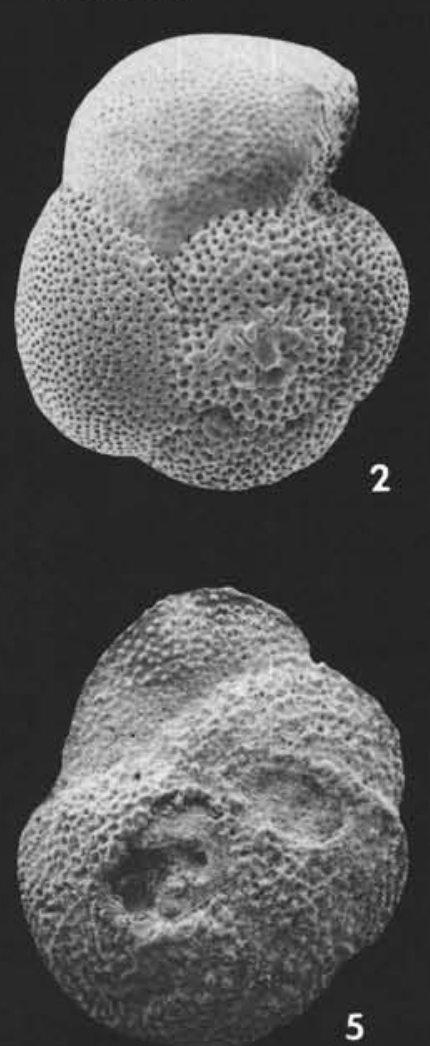

4

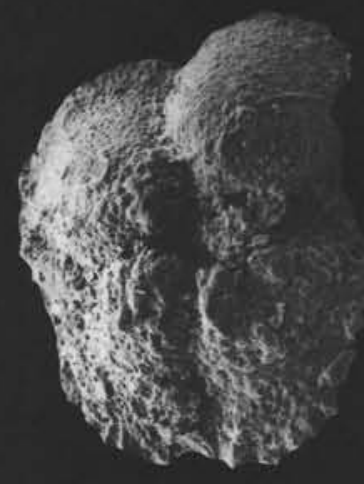

7

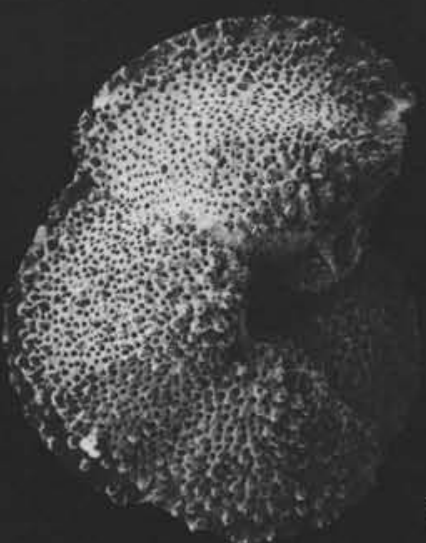

10
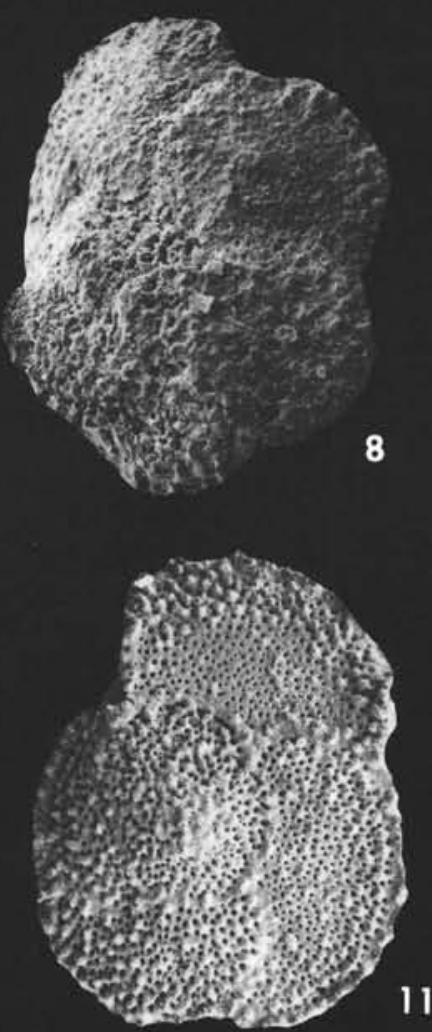
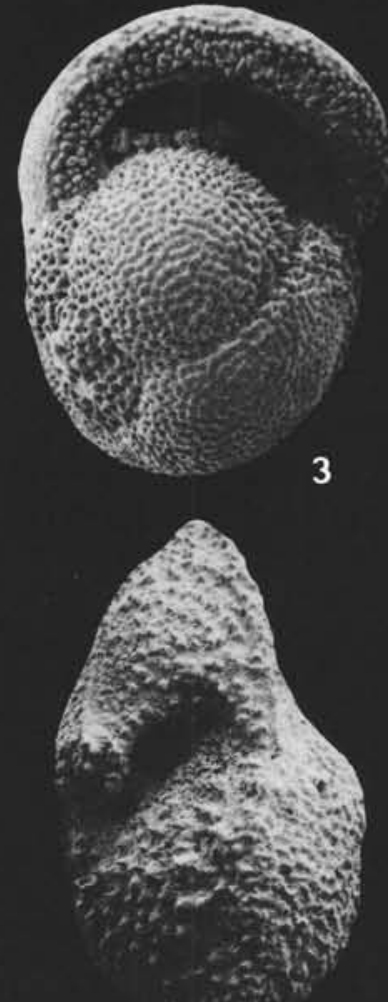

6
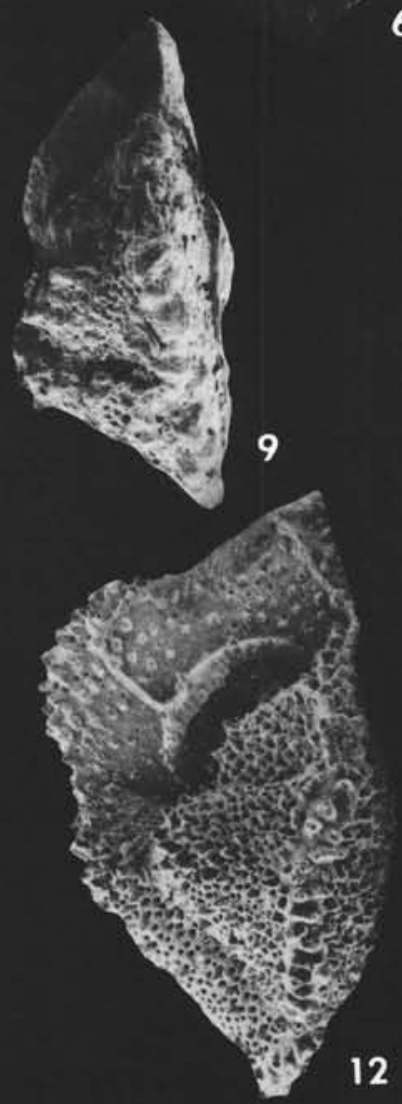


\section{PLATE 24}

Figures 1-4 Globorotalia margaritae Bolli and Bermudez. Site 200, Core 3, Section 3; Sphaeroidinella dehiscensGloboquadrina altispira Zone; Pliocene.

1. Umbilical view, $X 140$.

2. Umbilical view, $\times 85$.

3. Spiral view, $\times 85$.

4. Side view, $\times 97$.

Figures 5-7 Globorotalia marginodentata Subbotina. Site 200A, Core 2, core catcher; Globorotalia formosa formosa Zone; early Eocene.

5. Umbilical view, $\times 90$.

6. Spiral view, $\times 90$.

7. Side view, $\times 90$.

Figures 8-10 Globorotalia marksi Martin. Site 200A, Core 2, core catcher; Globorotalia formosa formosa Zone; early Eocene.

8. Umbilical view, $X 112$.

9. Spiral view, $X 112$.

10. Side view, $X 112$.

Figures 11-13 Globorotalia menardii (Parker, Jones and Brady). Site 200, Core 6, core catcher; Globorotalia acostaensisGloborotalia merotumida Zone; late Miocene.

11. Umbilical view, $X 95$.

12. Spiral view, $\times 100$.

13. Side view, $X 104$. 


\section{PLATE 24}
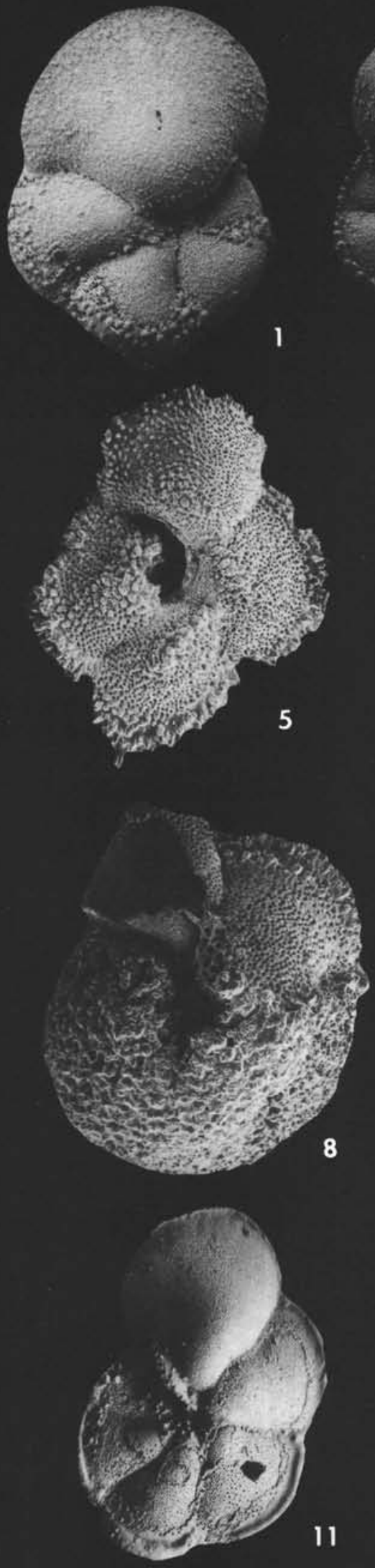
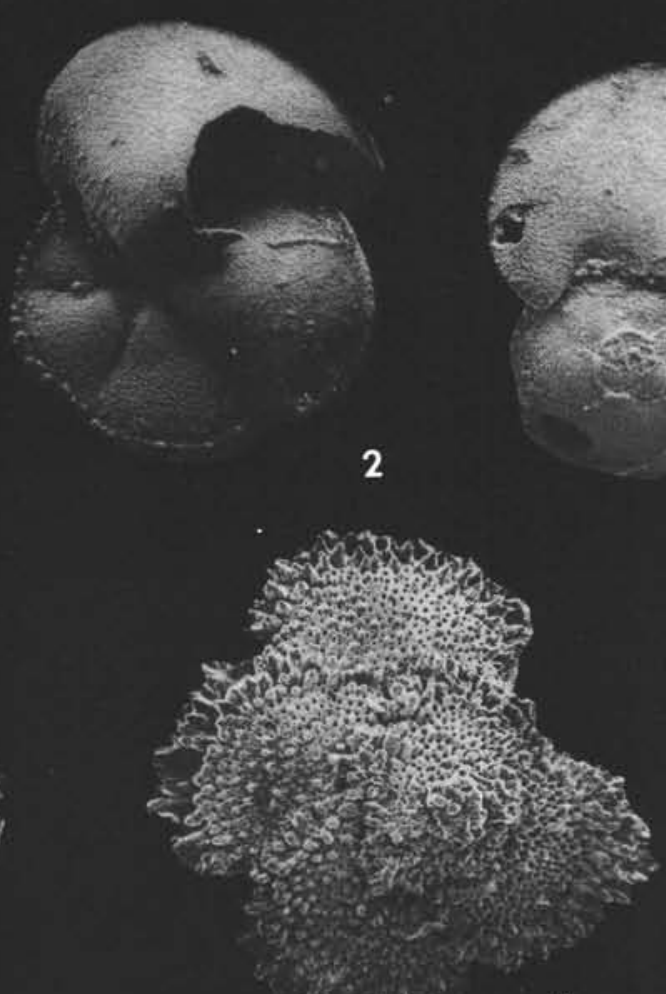

6
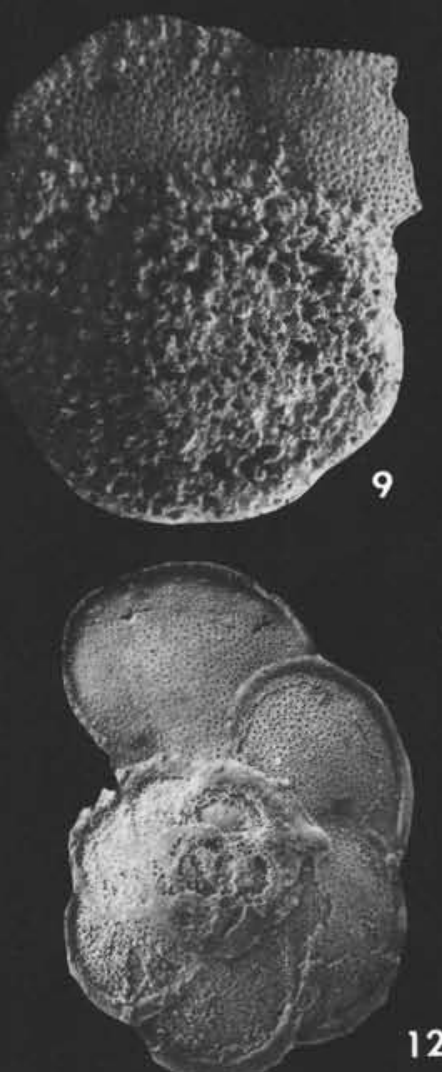

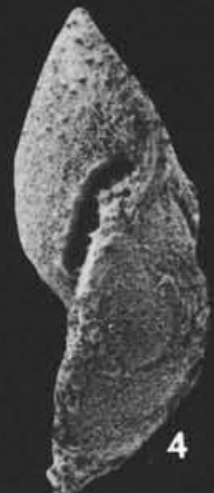

3
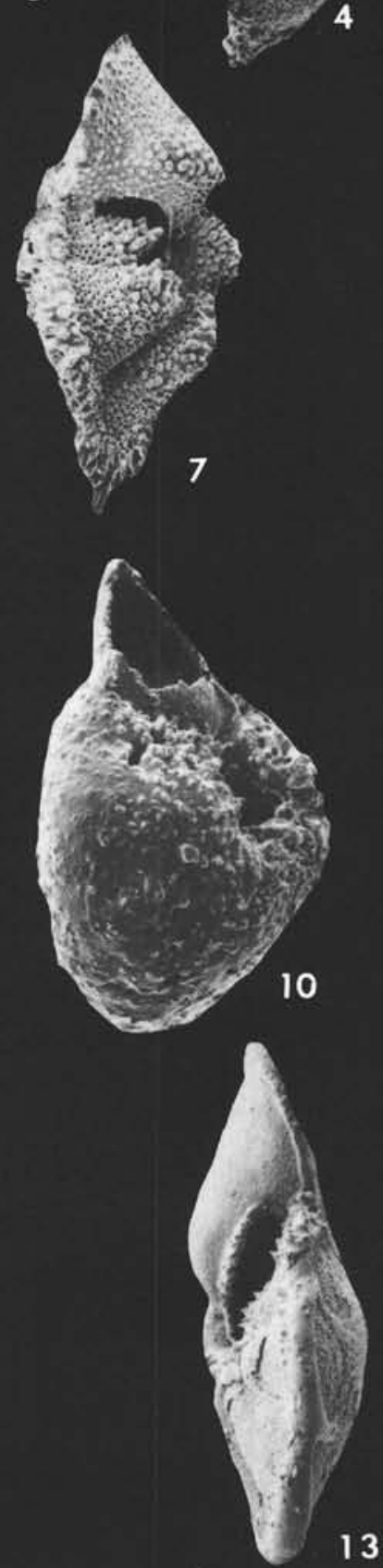
PLATE 25

Figures 1-3 Globorotalia merotumida Blow and Banner. Site 200, Core 6, core catcher; Globorotalia acostaensis-Globorotalia merotumida Zone; late Miocene.

1. Umbilical view, $X 120$.

2. Spiral view, $X 105$.

3. Side view, $X 110$.

Figures 4-6 Globorotalia miocenica Palmer. Site 200, Core 5, core catcher; Globorotalia plesiotumida Zone; late Miocene.

4. Umbilical view, $\times 100$.

5. Spiral view, $X 75$.

6. Side view, $\times 120$.

Figures 7-9 Globorotalia multicamerata Cushman and Jarvis. Core 200, Core 4, Section 1; Globorotalia tumidaSphaeroidinellopsis subdehiscens paenodehiscens Zone; Pliocene.

7. Umbilical view, $\times 72$.

8. Spiral view, $\times 78$.

9. Side view, $X 82$. 


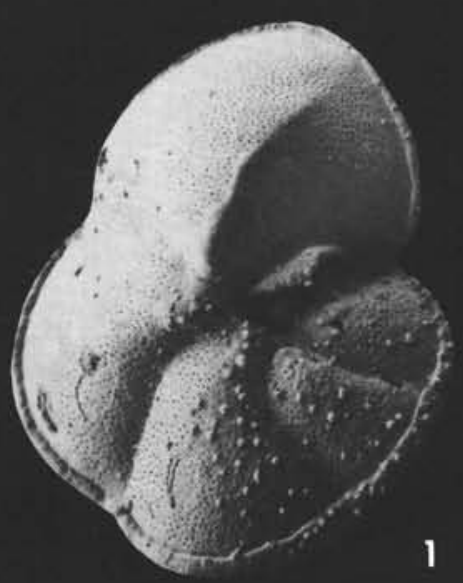

\section{PLATE 25}
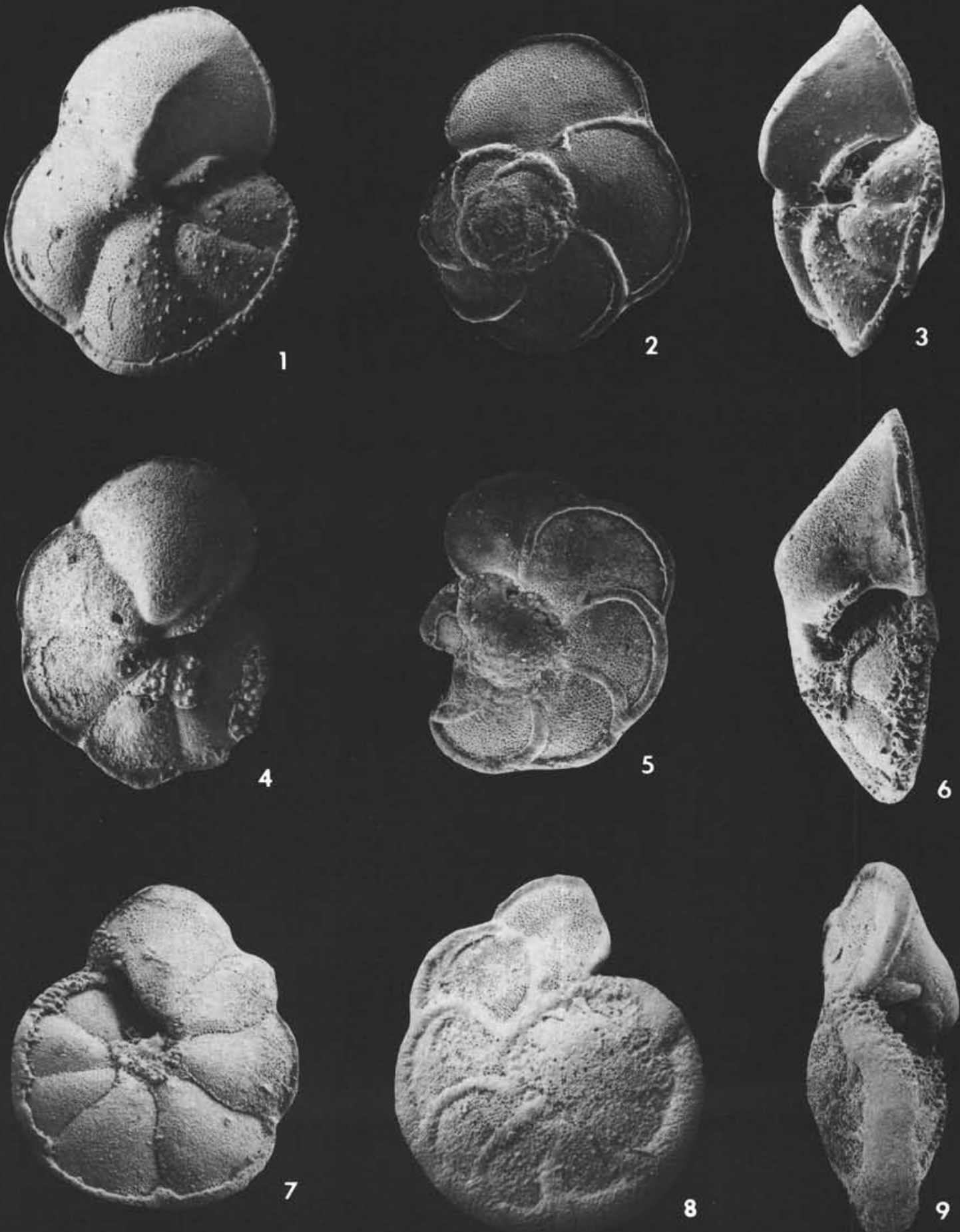


\section{PLATE 26}

Figures 1-3 Globorotalia naussi Martin. Site 200A, Core 2, core catcher; Globorotalia formosa formosa Zone; early Eocene.

1. Umbilical view, $\times 185$.

2. Spiral view, $X 175$.

3. Side view, $\times 175$.

Figures 4-6 Globorotalia occlusa Loeblich and Tappan. Site 199, Core 10, Section $2(37-38 \mathrm{~cm})$; Globorotalia velascoensis Zone; late Paleocene.

4. Umbilical view, $\times 160$.

5. Spiral view, $X 175$.

6. Side view, $X 170$.

Figures 7-9 Globorotalia peripheroronda Blow and Banner. Site 200, Core 9, core catcher; Globigerinoides sicanusGlobigerinatella insueta Zone; early Miocene.

7. Umbilical view, $X 115$.

8. Spiral view, $X 102$.

9. Side view, $\times 135$.

Figures 10-12 Globorotalia plesiotumida Blow and Banner. Site 200, Core 5, core catcher; Globorotalia plesiotumida Zone; late Miocene.

10. Umbilical view, $\times 70$.

11. Spiral view, $X 70$.

12. Side view, $\times 72$. 

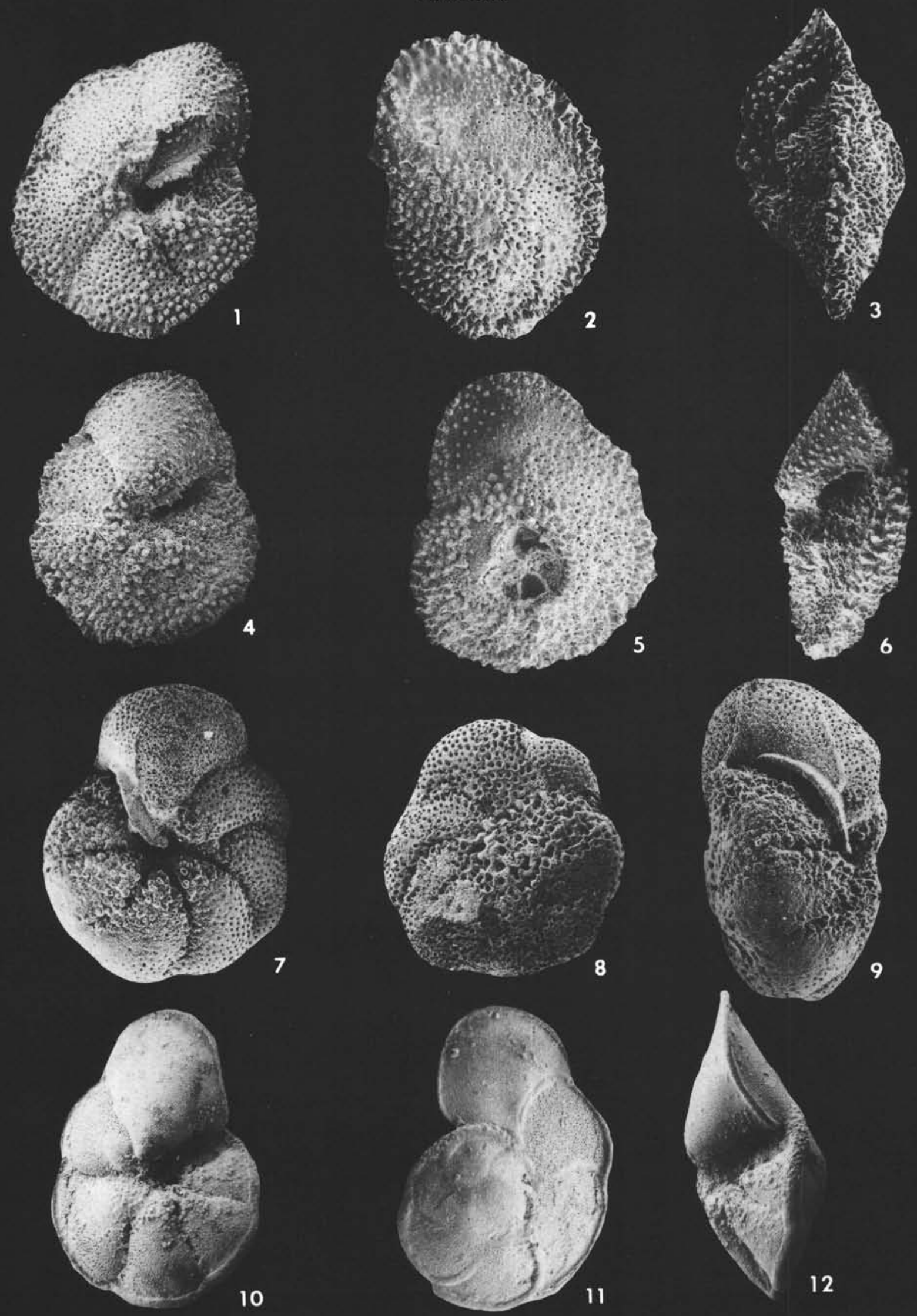


\section{PLATE 27}

Figures 1-3 Globorotalia pseudomenardii Bolli. Site 199, Core 10, Section 2 (37-38 cm); Globorotalia pseudomenardii Zone; late Paleocene.

1. Umbilical view, $X 135$.

2. Spiral view, $X 135$.

3. Side view, $\times 150$.

Figures 4-6

Globorotalia pseudopachyderma Cita, Premoli Silva, and Rossi. Site 200, Core 6, core catcher; Globorotalia acostaensis-Globorotalia merotumida Zone; late Miocene.

4. Umbilical view, $\times 200$.

5. Spiral view, $X 180$.

6. Side view, $\times 200$.

Figures 7-9 Globorotalia pseudoscitula Glaessner. Site 200A, Core 2, core catcher; Globorotalia formosa formosa Zone; early Eocene.

7. Umbilical view, $\times 220$.

8. Spiral view, $\times 220$.

9. Side view, $\times 260$.

Figures 10-12 Globorotalia quetra Bolli. Site 200A, Core 2, core catcher; Globorotalia formosa formosa Zone; early Eocene.

10. Umbilical view, $\times 97$.

11. Spiral view, $\times 97$.

12. Edge view, $\times 87$. 


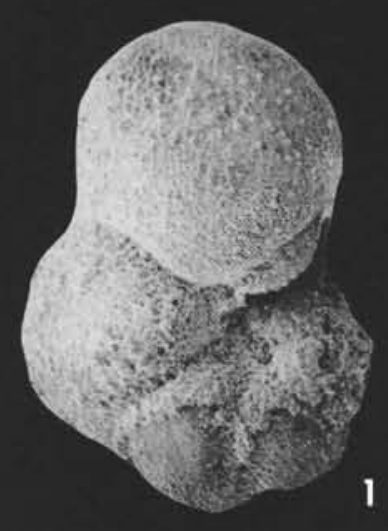

1

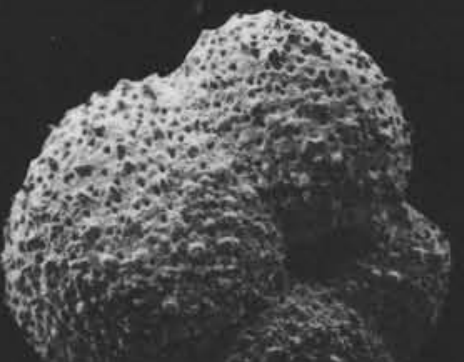

4
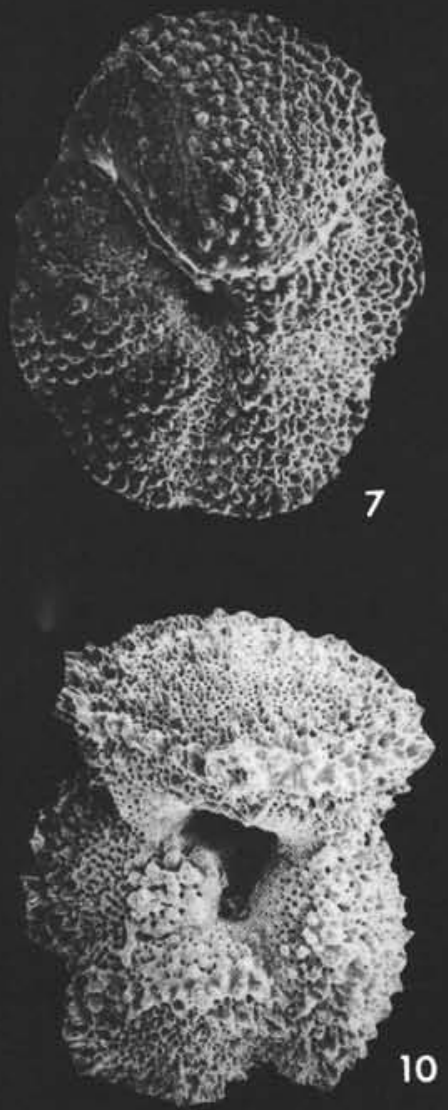

Plate 27
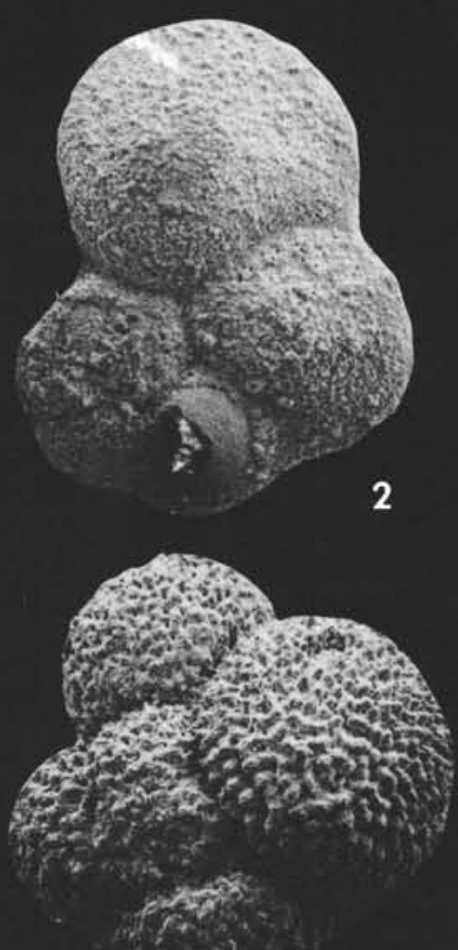

5
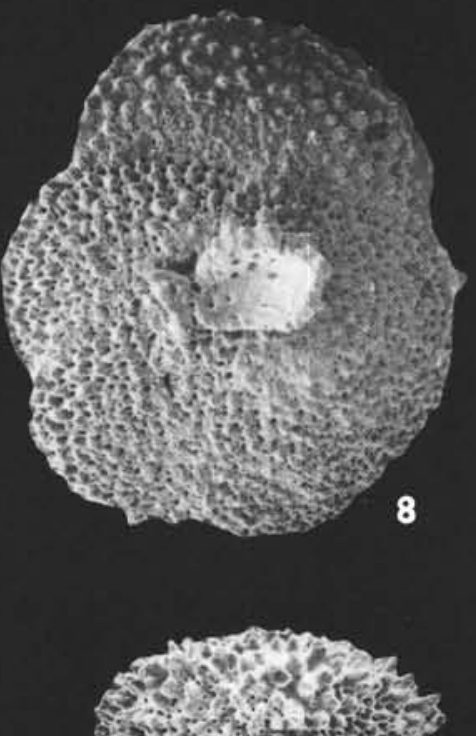

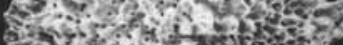
E3)

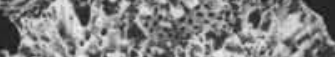

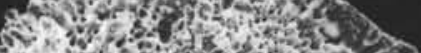

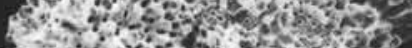

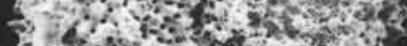

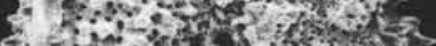

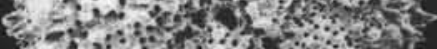

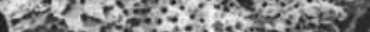

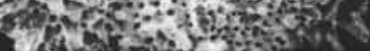

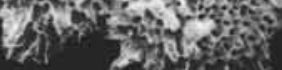
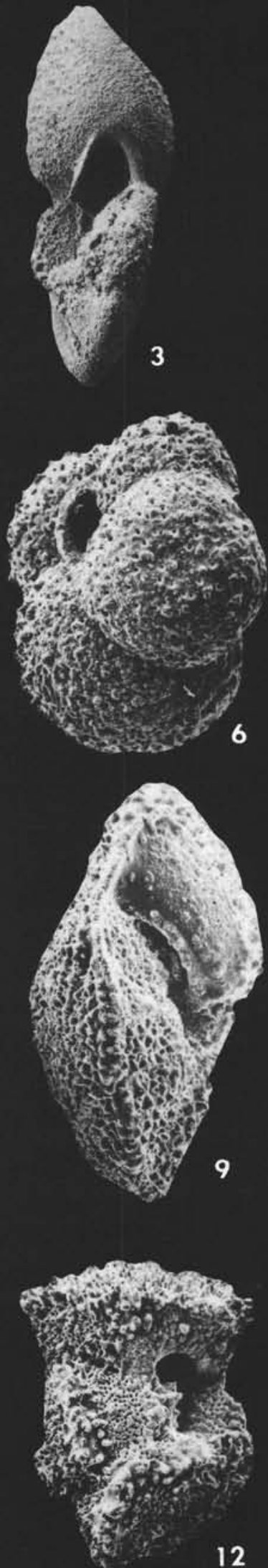


\section{PLATE 28}

Figures 1-3 Globorotalia scitula (Brady). Site 200, Core 1, Section 1; Globorotalia truncatulinoides Zone; Pleistocene.

1. Umbilical view, $\times 105$.

2. Spiral view, $X 105$.

3. Side view, $\times 117$.

Figures 4-6 Globorotalia siakensis Le Roy. Site 200, Core 10, core catcher (Hard limestone); Globigerinatella insueta-Globigerinita dissimilis Zone; early Miocene.

4. Umbilical view, $X 140$.

5. Spiral view, $\times 170$.

6. Side view, $\times 170$.

Figures 7-9 Globorotalia spinulosa Cushman. Site 202, Core 2, core catcher; Orbulinoides beckmanni Zone; middle Eocene.
7. Umbilical view, $X 100$.
8. Spiral view, $X 100$.
9. Side view, $X 118$.

Figures 10-12 Globorotalia subbotinae Morozova. Site 200A, Core 2, core catcher; Globorotalia formosa formosa Zone; early Eocene.

10. Umbilical view, $X 135$.

11. Spiral view, $\times 135$.

12. Side view, $X 125$. 


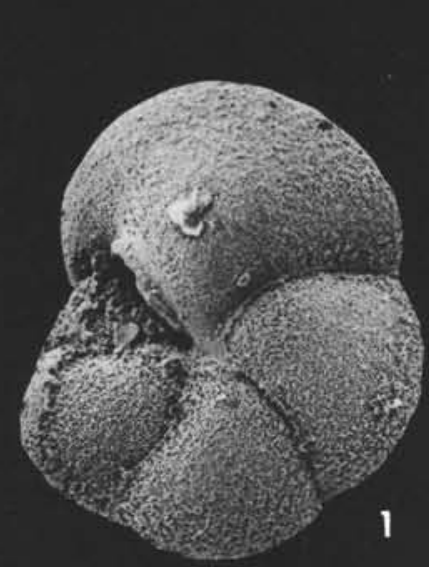

PLATE 28
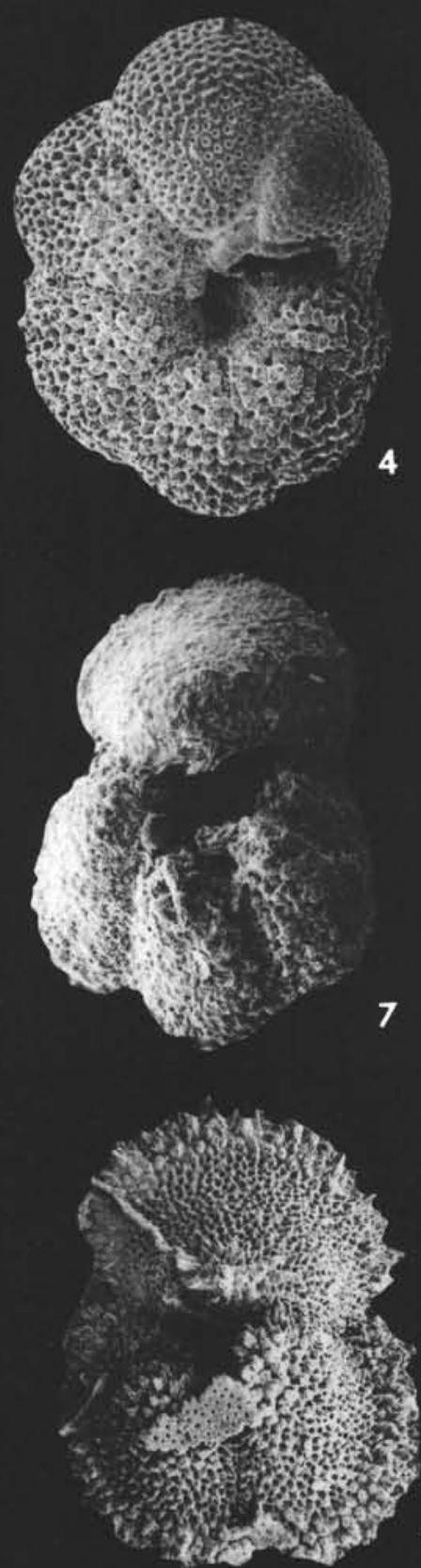

10
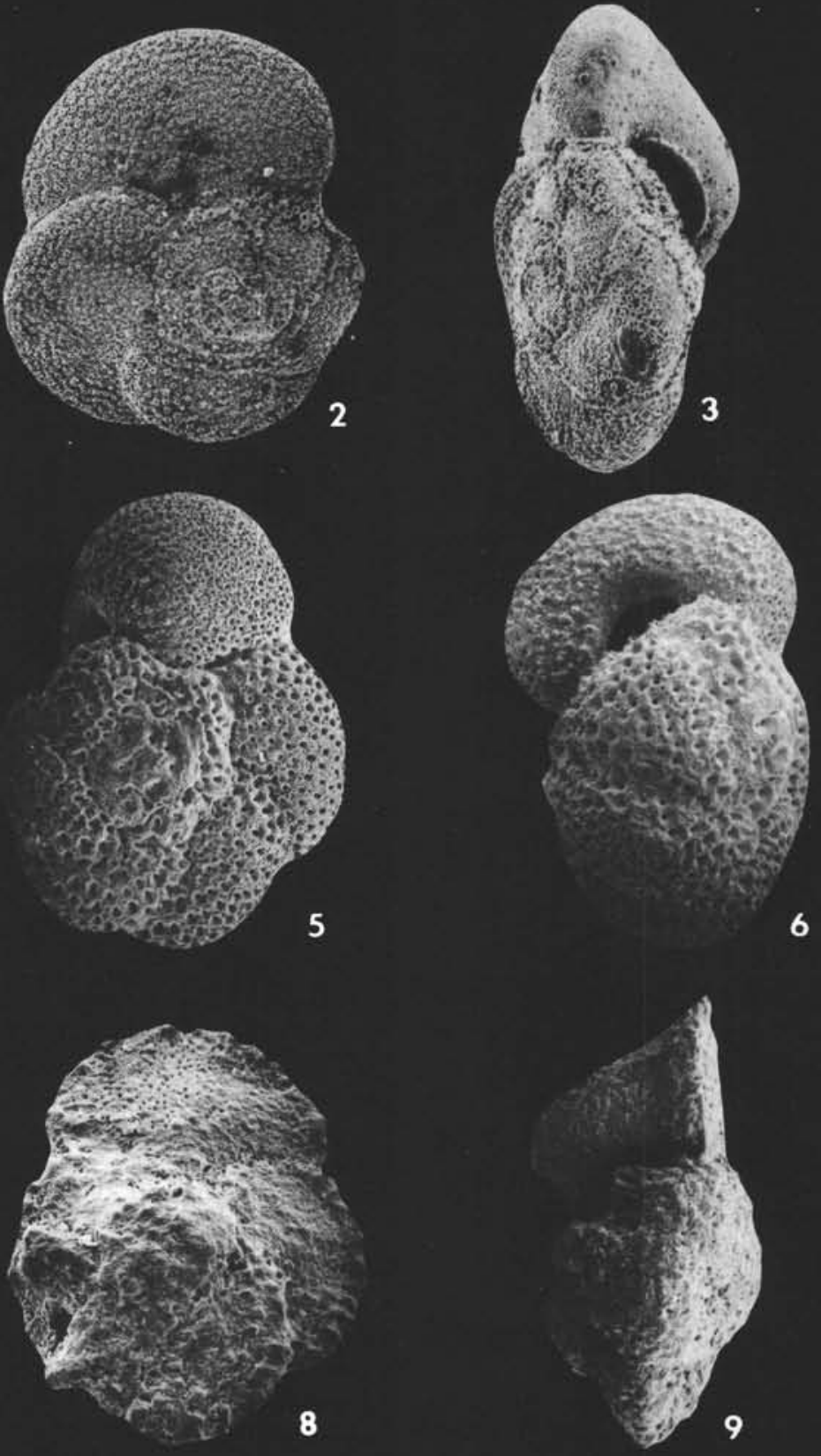

6
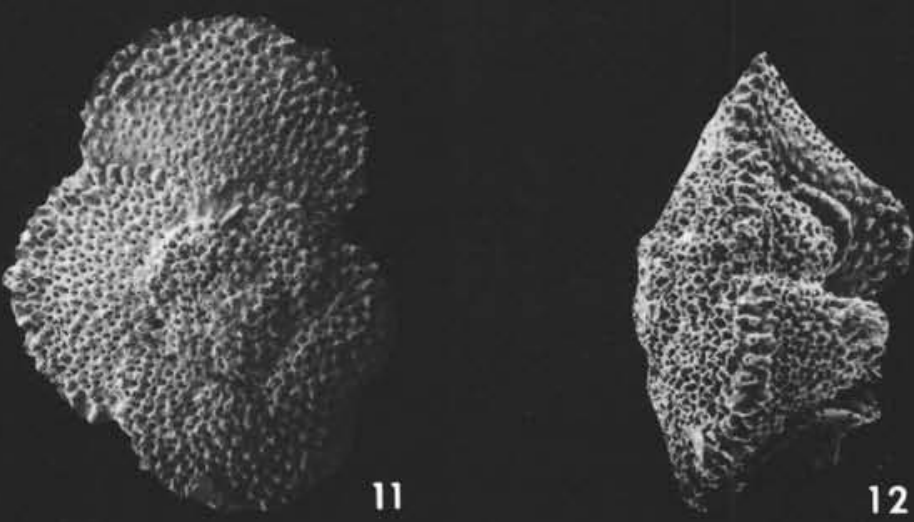

12 


\section{PLATE 29}

Figures 1-3 Globorotalia tosaensis Takayanagi and Saito. Site 200, Core 2, Section 2; Globorotalia tosaensis Zone.

1. Umbilical view, $\times 125$.

2. Spiral view, $X 100$.

3. Side view, $\times 115$.

Figures 4-6 Globorotalia troelseni Loeblich and Tappan. Site 200A, Core 2, core catcher; Globorotalia formosa formosa Zone; early Eocene.

4. Umbilical view, $\times 190$.

5. Spiral view, $X 177$.

6. Edge view, $\times 207$.

Figures 7-9 Globorotalia truncatulinoides (d'Orbigny). Site 200, Core 1, Section 1; Globorotalia truncatulinoides Zone; Pleistocene.

7. Umbilical view, $\times 76$.

8. Spiral view, $\times 74$.

9. Side view, $X 69$.

Figures 10-12 Globorotalia tumida (Brady). Site 200, Core 1, Section 1; Globorotalia truncatulinoides Zone; Pleistocene.

10. Umbilical view, $\times 52$.

11. Spiral view, $\times 53$.

12. Edge view, $X 58$. 


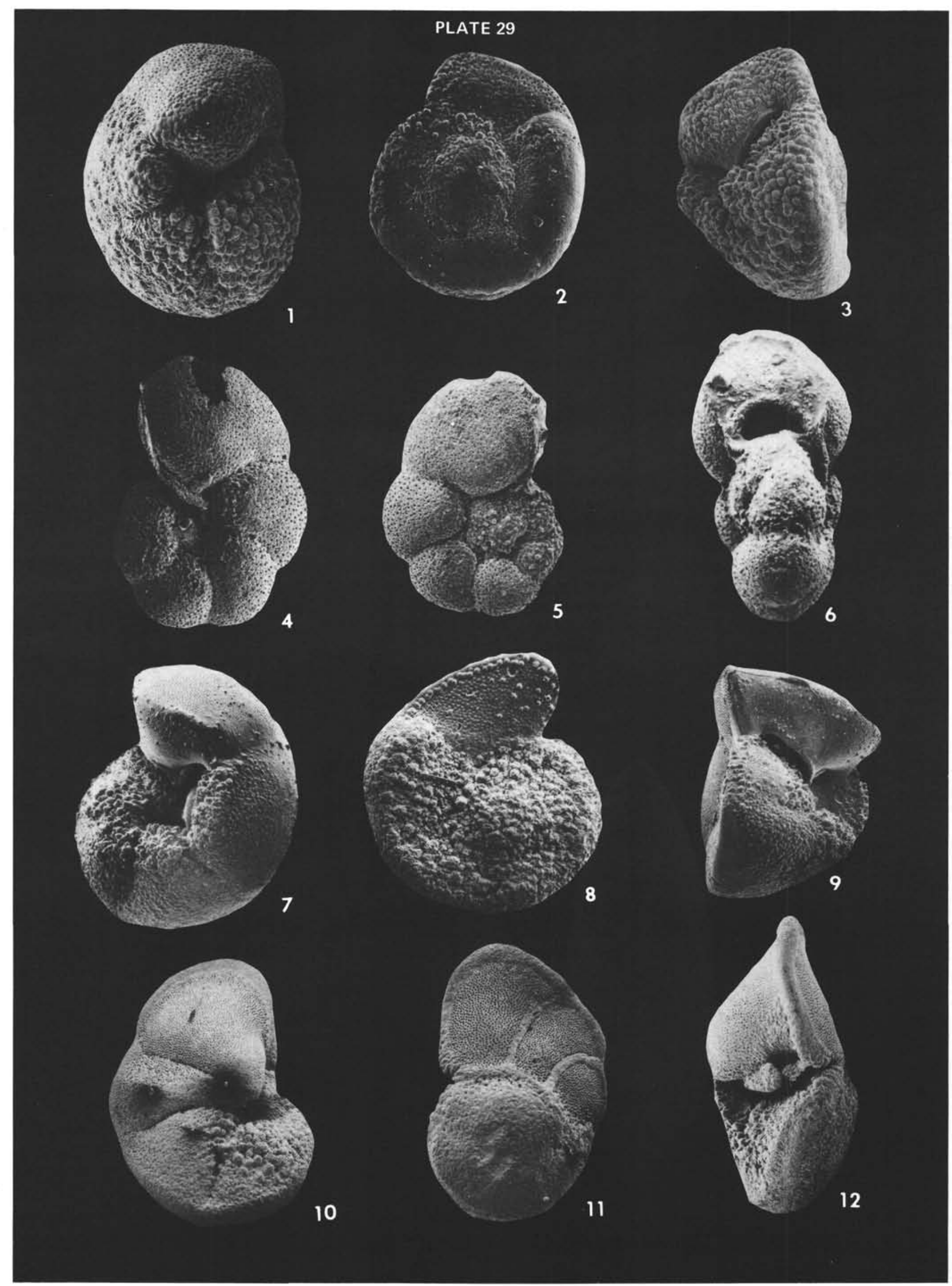




\section{PLATE 30}

Figures 1-3 Globorotalia ungulata Bermudez. Site 200, Core 3, core catcher; Sphaeroidinella dehiscens-Globoquadrina altispira Zone; early Pliocene.

1. Umbilical view, $\times 98$.

2. Spiral view, $\times 88$.

3. Side view, $\times 95$.

Figures 4-6 Globorotalia velascoensis Cushman. Site 199, Core 10, Section 2; Globorotalia velascoensis Zone; late Paleocene.

4. Umbilical view, $\times 98$.

5. Spiral view, $\times 94$.

6. Side view, $\times 106$.

Figures 7-9 Globorotalia wilcoxensis Cushman and Ponton. Site 200A, Core 2, core catcher; Globoratalia formosa formosa Zone; early Eocene.

7. Umbilical view, $X 110$.

8. Spiral view, $\times 100$.

9. Side view, $X 110$.

Figures 10-12 Globorotaloides hexagona (Natland). Site 200, Core 2, Section 2; Globorotalia tosaensis Zone; late Pliocene.

10. Umbilical view, $\times 160$.

11. Spiral view, $\times 160$.

12. Edge view, $\times 160$. 

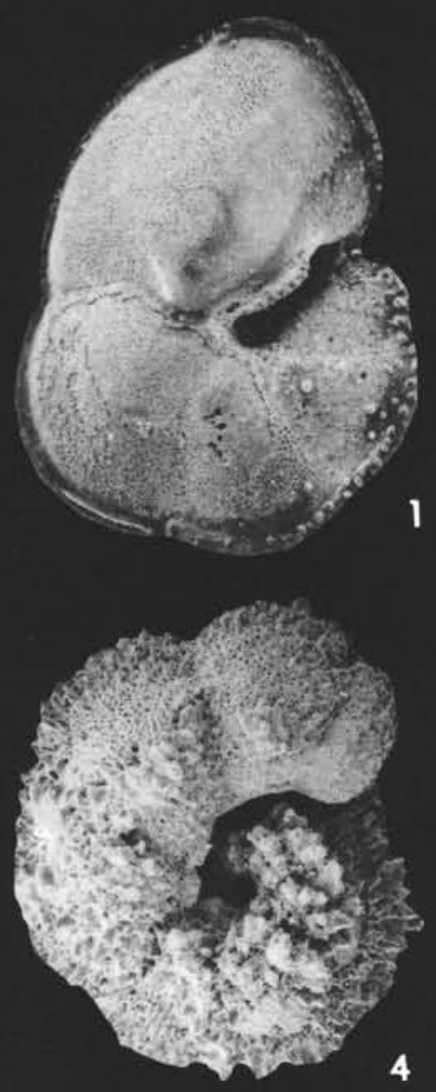

4
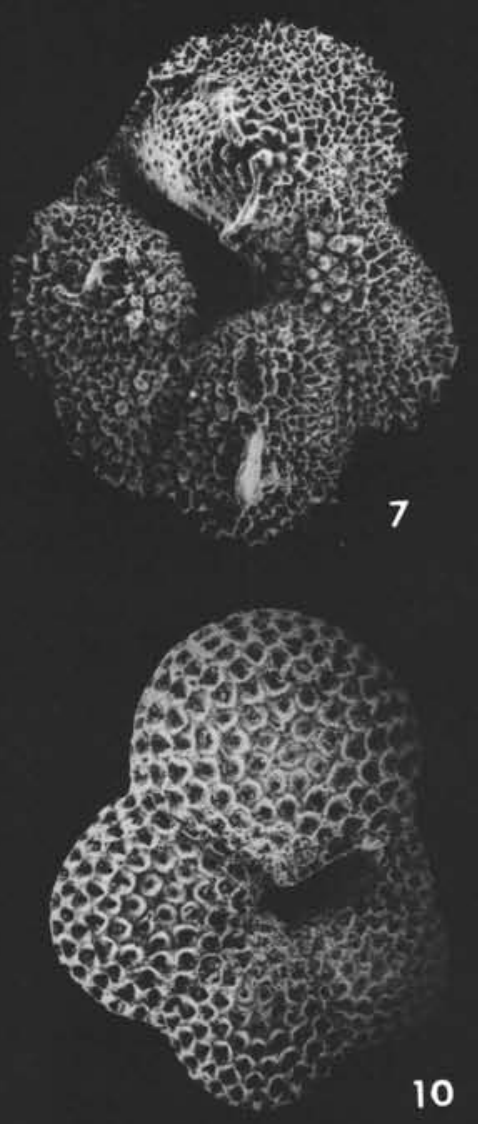
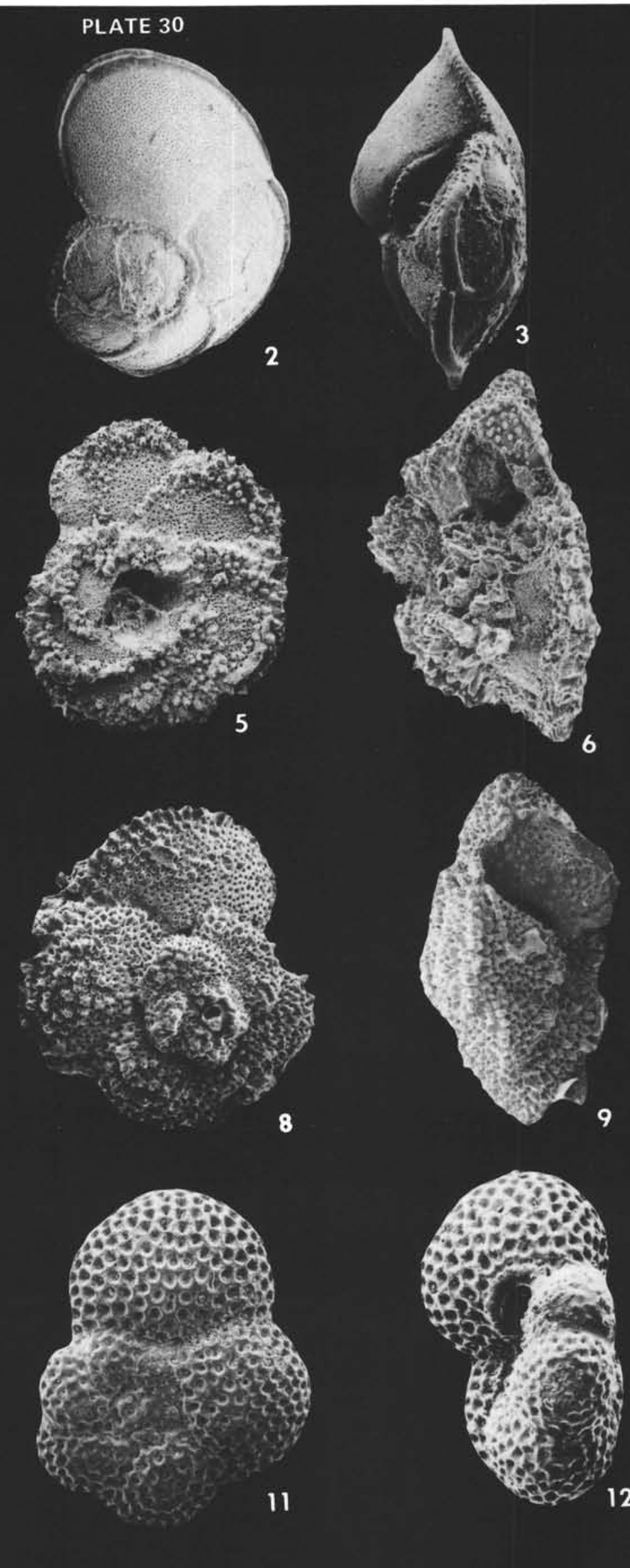


\section{PLATE 31}

Figures 1-2 Guembelitria irregularis Morozova. Site 199, Core 10, Section 2; "Globigerina" eugubina Zone.

1. Umbilical view $\times 500$.

2. Spiral view, $\times 550$.

Figures 3, 6 Hantkenina alabamensis Cushman. Site 202, Core 2, core catcher; Orbulinoides beckmanni Zone; middle Eocene.

3. Side view, $\times 75$.

6. Edge view, $\times 92$.

Figures 4-5 Hastigerina pelagica (d'Orbigny). Site 200, Core 6, core catcher; Globorotalia acostaensis-Globorotalia merotumida Zone; late Miocene.

4. Edge view, $\times 150$.

5. Side view, $\times 150$.

Figures 7-9 Hastigerna siphonifera (d'Orbigny). Site 200, Core 6, core catcher; Globorotalia acostaensis-Globorotalia merotumida Zone; late Miocene.

7. Edge view, $\times 87$.

8. Side view, $\times 90$.

9. Edge view, $\times 82$.

Figure 10 Orbulina suturalis Bronnimann; $\times 100$. Site 200, Core 9, Section 1 (top); Orbulina suturalis Zone; middle Miocene.

Figure 11 Orbulina universa d'Orbigny; X90. Site 200, Core 6, core catcher; Globorotalia acostaensis-Globorotalia merotumida Zone; late Miocene.

Figure 12 Orbulinoides beckmanni (Saito); $\times 75$. Site 202, Core 2, core catcher; Orbulinoides beckmanni Zone; middle Eocene. 


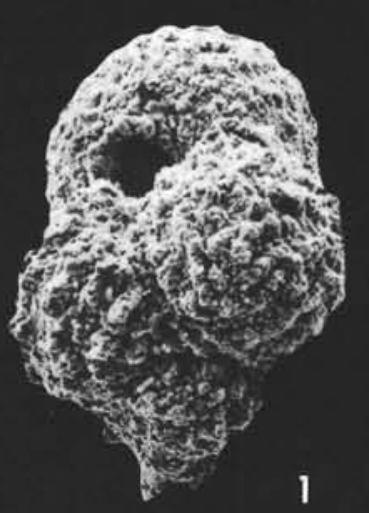

\section{PLATE 31}
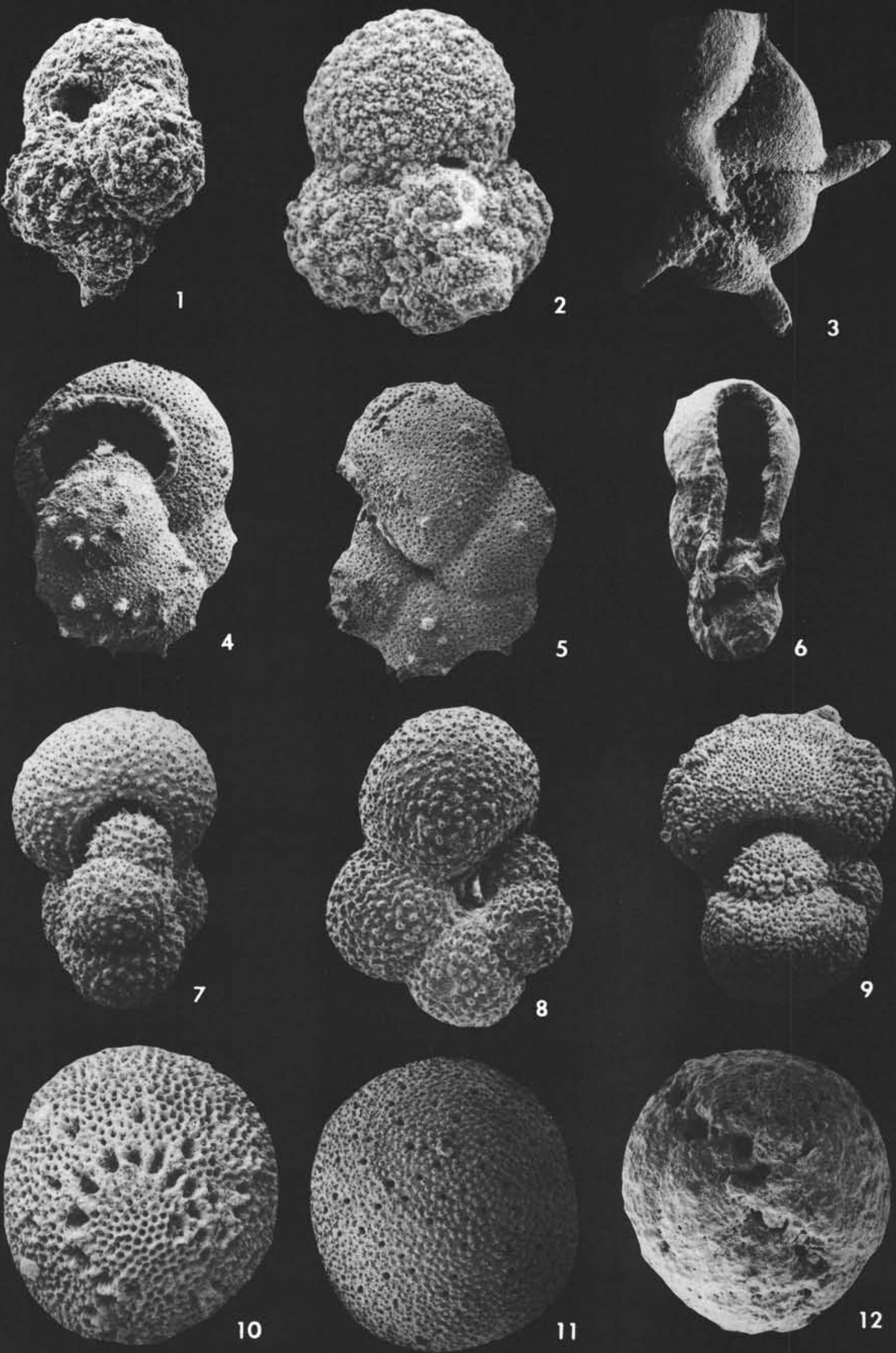


\section{PLATE 32}

Figure 1 Praeorbulina glomerosa curva (Blow); $\times 85$. Site 200, Core 9, Section 2; Globigerinoides sicanus-Globigerinatella insueta Zone; early Miocene.

Figure 2 Praeorbulina glomerosa glomerosa (Blow); $\times 100$. Site 200, Core 9, Section 1; Orbulina suturalis Zone; middle Miocene.

Figures 3-4 Praeorbulina transistoria (Blow). Site 200, Core 9, Section 5; Globigerinoides sicanus-Globigerinatella insueta Zone; early Miocene.

3. Spiral view, $\times 85$.

4. Umbilical view, $\times 82$.

Figures 5-7 Pullenilatina obliquiloculata (Parker and Jones). Site 200, Core 3, core catcher; Sphaeroidinella dehiscensGloboquadrina altispira Zone; Pliocene.

5. Umbilical view, $\times 107$.

6. Spiral view, $\times 104$.

7. Side view, $X 100$.

Figures 8-10 Pulleniatina primalis Banner and Blow. Site 200, Core 5, core catcher; Globorotalia plesiotumida Zone; late Miocene.

8. Umbilical view, $\times 125$.

9. Spiral view, $\times 117$.

10. Side view, $X 130$. 


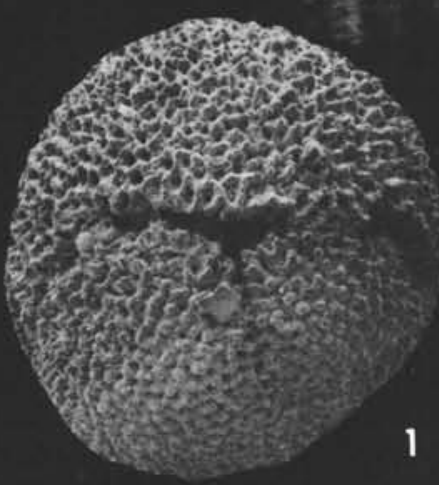

\section{PLATE 32}
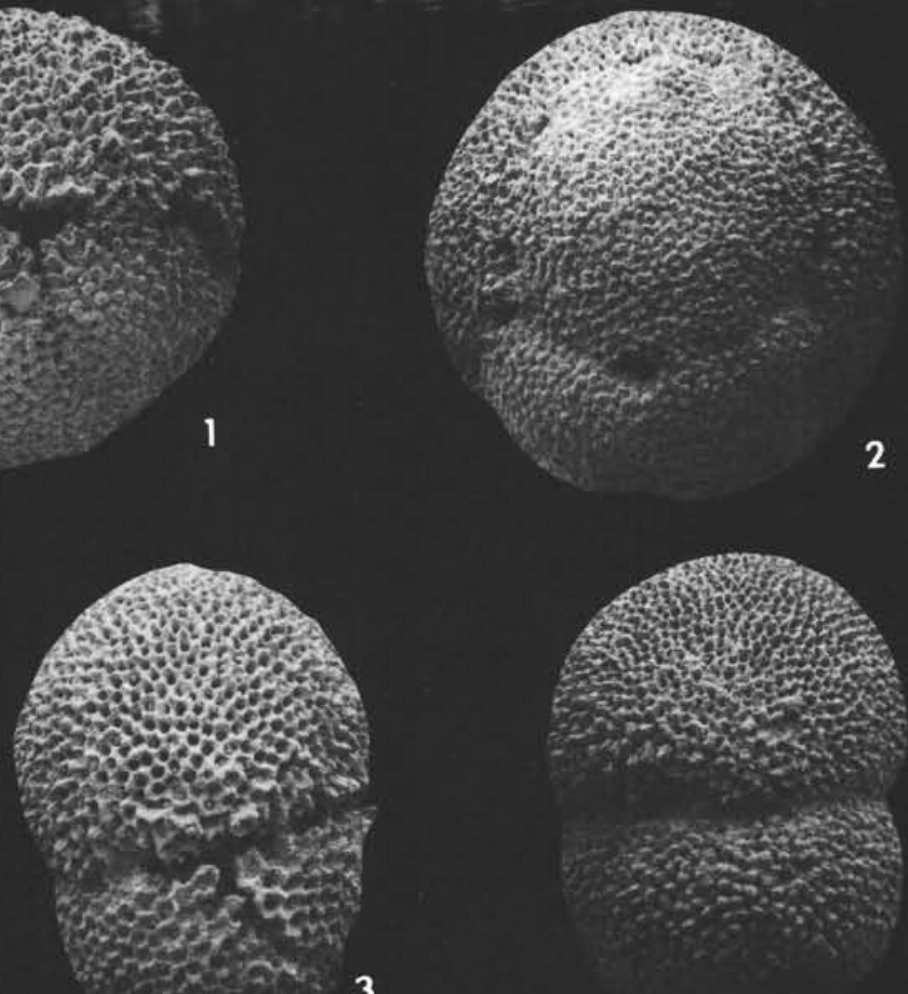

3
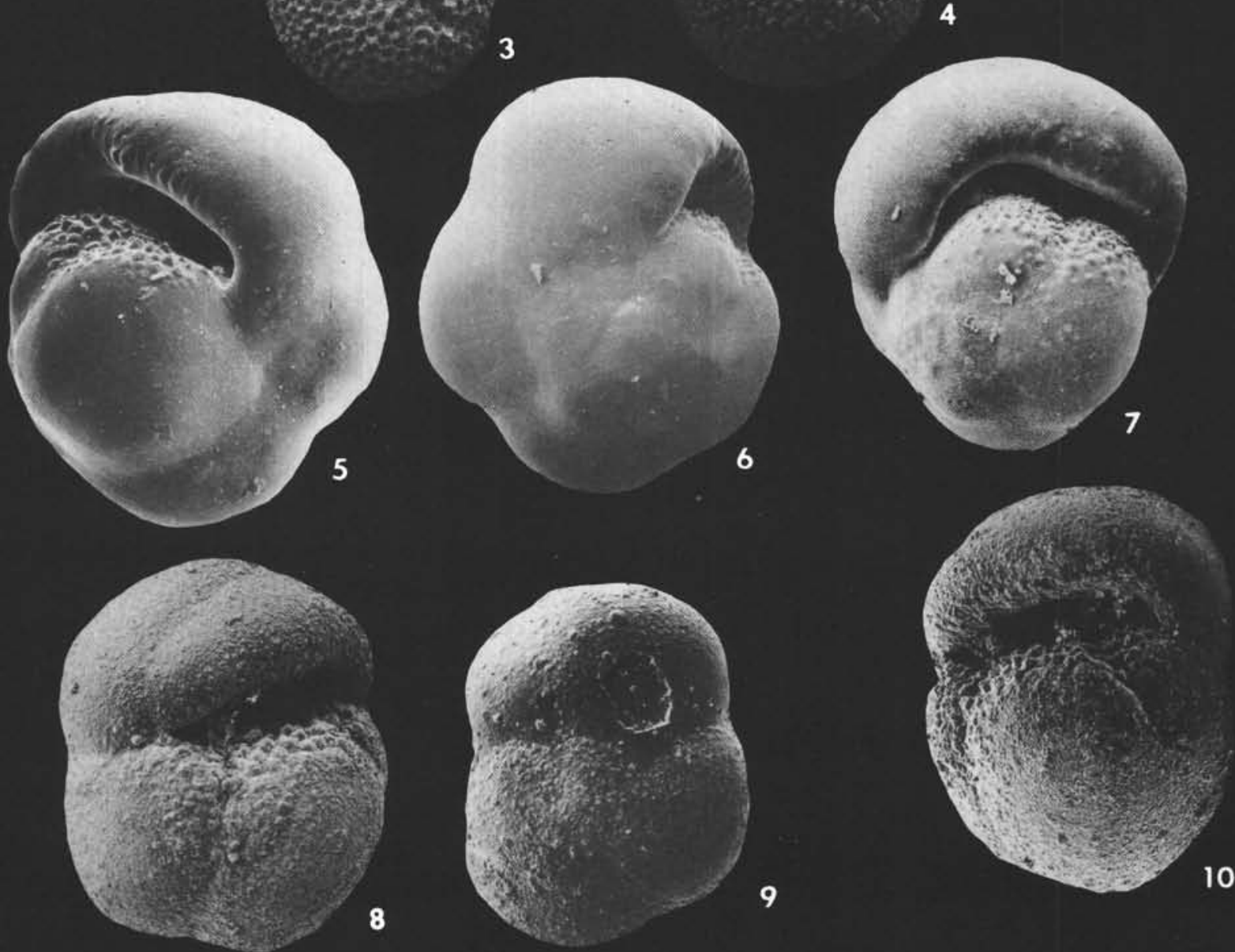
PLATE 33

Figures 1-3 Pulleniatina spectablis Parker. Site 200, Core 3, Section 4; Sphaeroidinella dehiscens-Globoquadrina altispira Zone.

1. Umbilical view, $\times 89$.

2. Spiral view, $\times 90$.

3. Side view, $\times 100$.

Figure 4-9 Rugoglobigerina? Site 199, Core 12; CampanianMaastrichtian 
PLATE 33
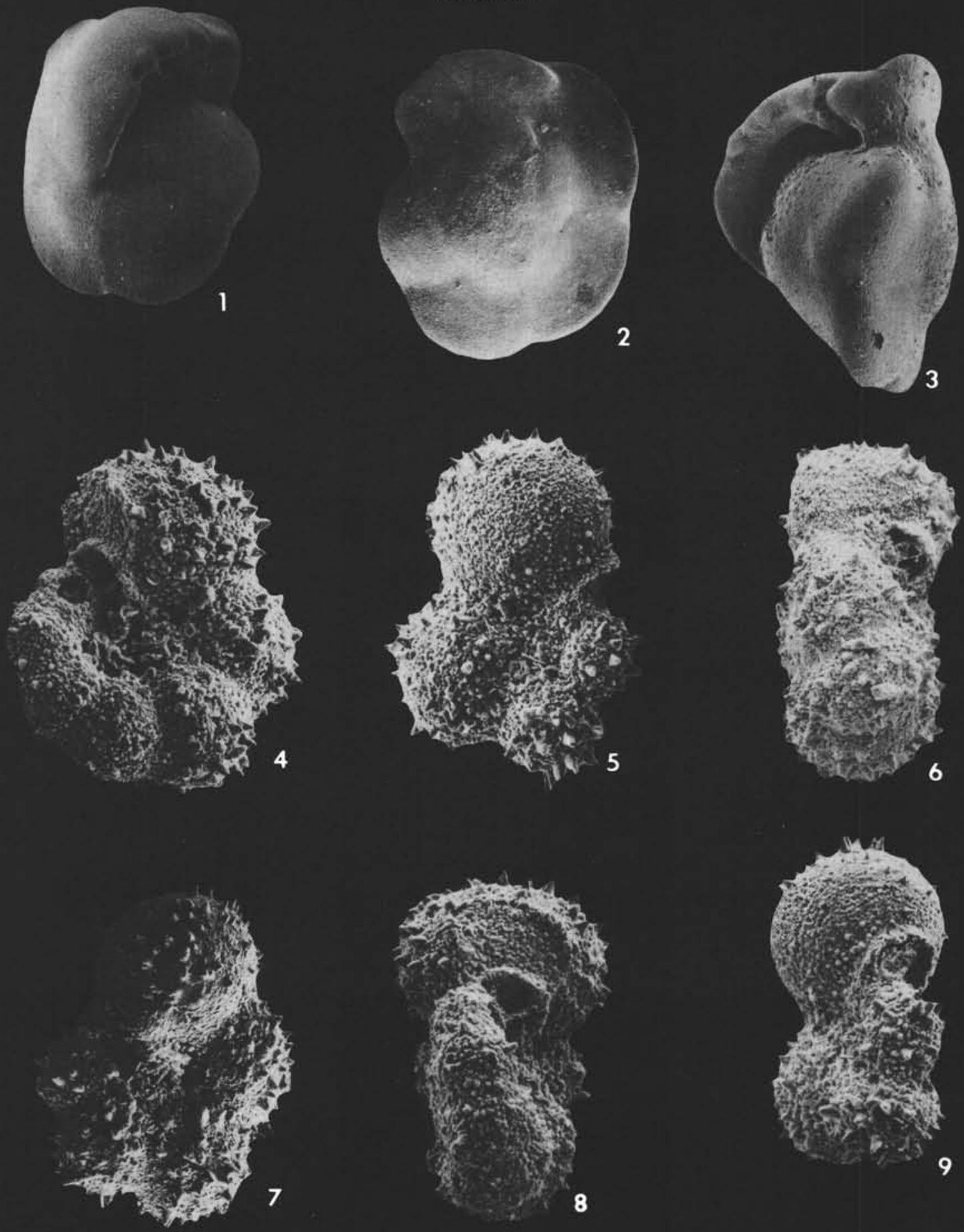


\section{PLATE 34}

Figures 1-2 Sphaeroidinella dehiscens (Parker and Jones). Site 200, Core 1, core catcher; Globorotalia truncatulinoides Zone; Pleistocene.

1. Umbilical view, $X 64$.

2. Spiral view, $\times 60$.

Figures 3-5 Sphaeroidinellopsis seminulina kochi (Caudri). Site 200, Core 4, Section 3; Globorotalia tumidaSphaeroidinellopsis subdehiscens paenodehiscens Zone; early Miocene.

3. Umbilical view, $\times 50$.

4. Spiral view, $\times 50$.

5. Side view, $\times 50$.

Figures 6-7 Sphaeroidinellopsis seminulina seminulina (Schwager). Site 200, Core 6, core catcher; Globorotalia acostaensis, Globorotalia merotumida Zone; late Miocene.

6. Umbilical view, $\times 86$.

7. Spiral view, $\times 72$.

Figures 8-9 Sphaeroidinellopsis subdehiscens (Blow). Site 200, Core 3, Section 4; Sphaeroidinella dehiscens-Globoquadrina altispira Zone; Pliocene.

8. Umbilical view, $X 130$.

9. Spiral view, $X 105$. 


\section{PLATE 34}

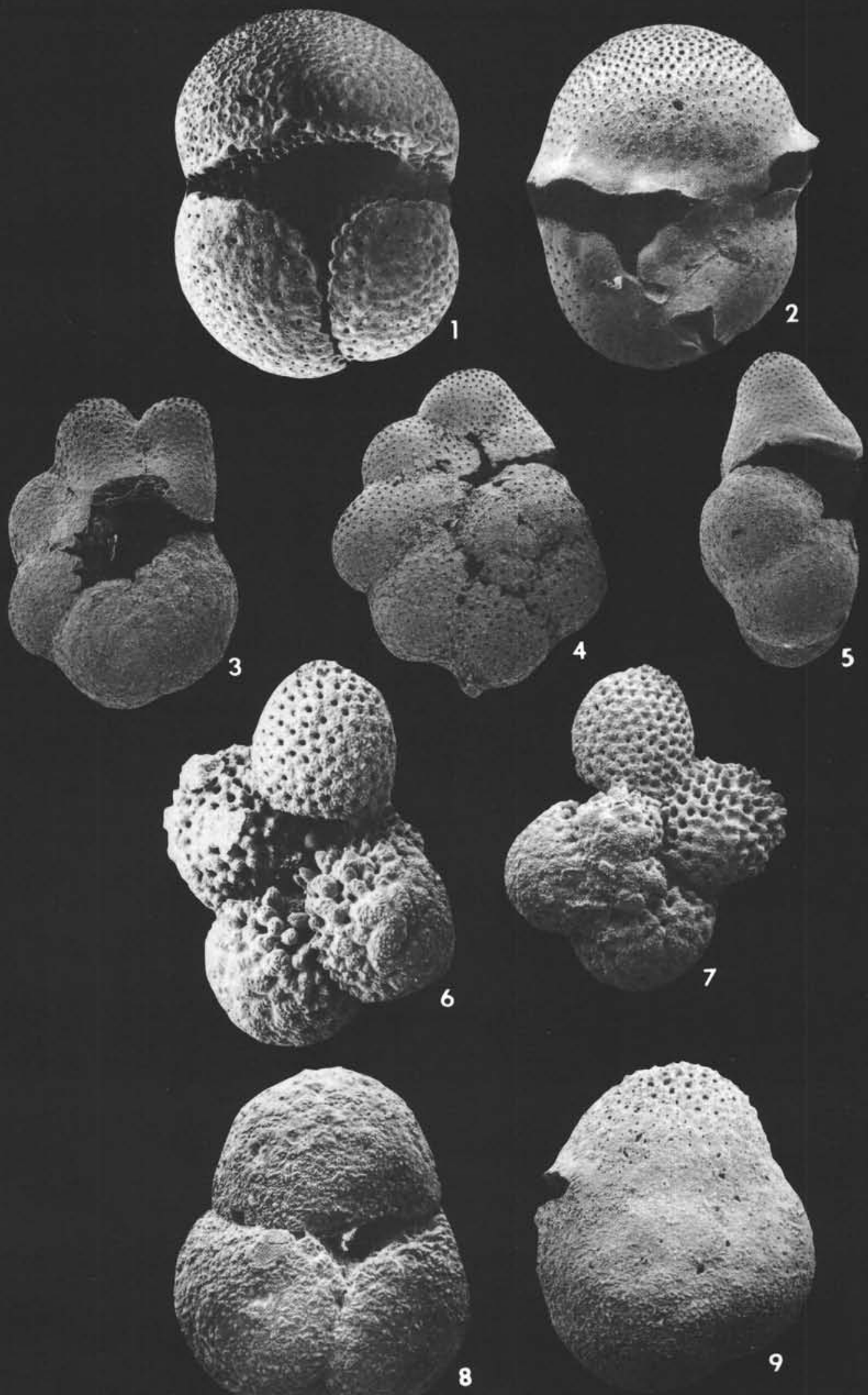




\section{PLATE 35}

Figures 1-3 Truncorotaloides rohri Bronnimann and Bermudez. Site 202, Core 2, core catcher; Orbulinoides beckmanni Zone; middle Eocene.

1. Umbilical view, $\times 160$.

2. Spiral view, $\times 160$.

3. Side view, $\times 160$.

Figures 4-6 Truncorotaloides topilensis (Cushman). Site 202, Core 2, core catcher, Orbulinoides beckmanni Zone; middle Eocene.

4. Umbilical view, $\times 135$.

5. Spiral view, $\times 130$.

6. Side view, $X 135$.

Figures 7-8 Turborotalita humilis (Brady). Site 200, Core 1, Section 1; Globorotalia truncatulinoides Zone; Pleistocene.

7. Umbilical view, $\times 275$.

8. Spiral view, $X 25$. 
PLATE 35
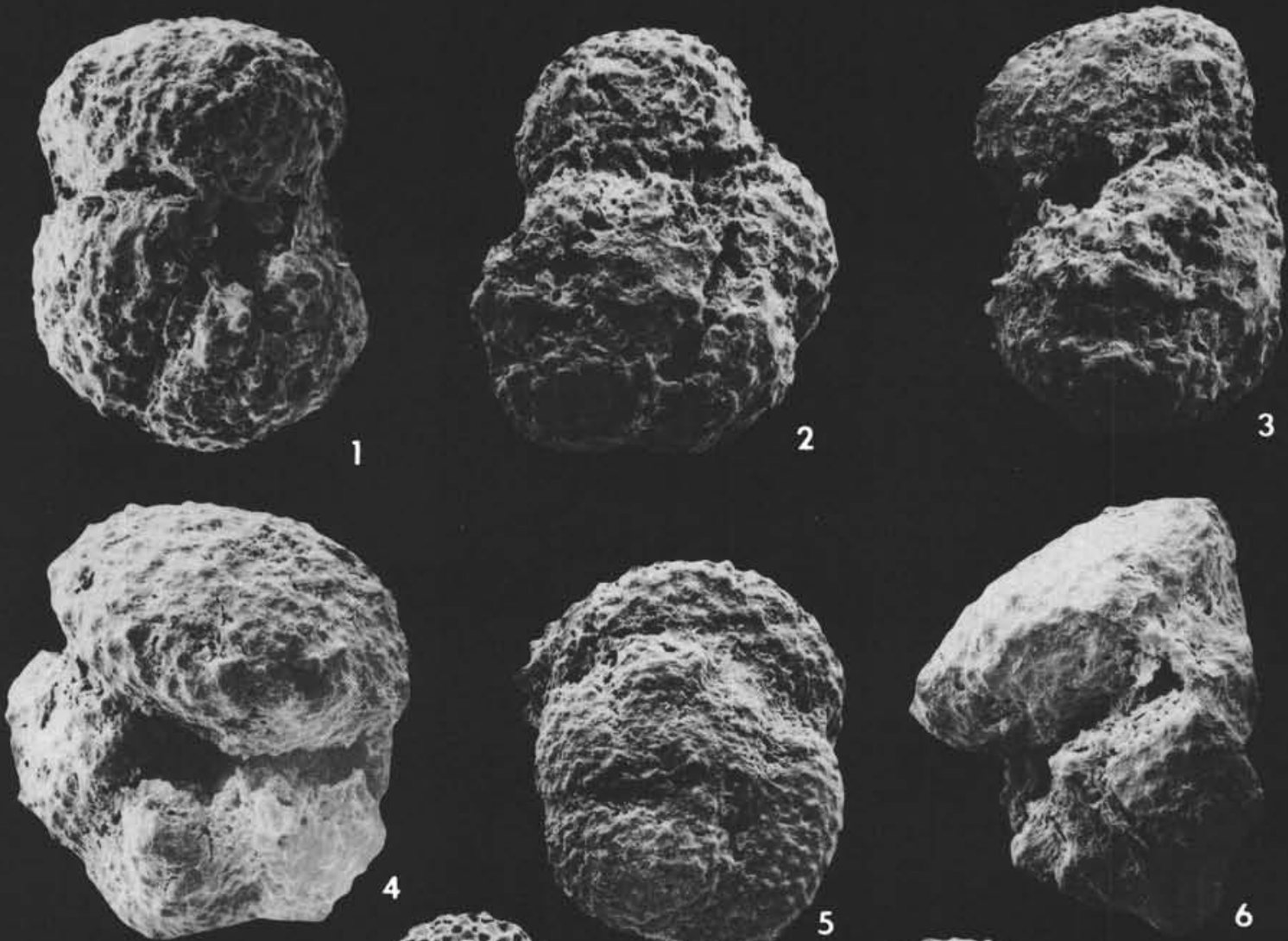

2
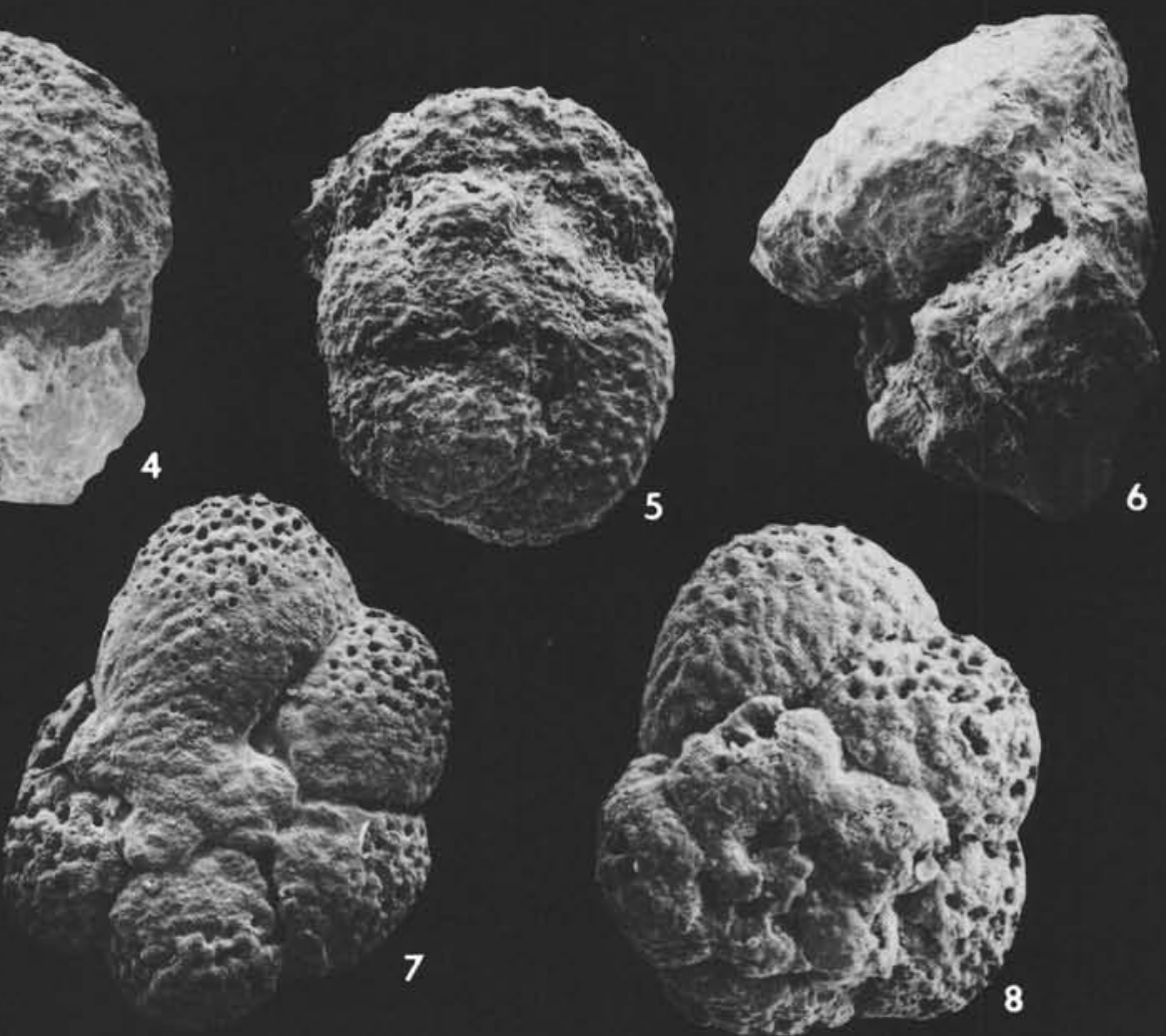

6 